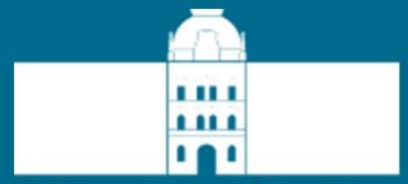

University of Maribor

\title{
$10^{\mathrm{TH}}$ International Conference on Sustainable Energy and Environmental Protection:
}

\section{Energy Management and Policies}

(June 27 ${ }^{\mathrm{TH}}-3^{\mathrm{TH}}, 2017$, Bled, Slovenia)

\section{(Conference Proceedings)}

Editors:

Emeritus Prof. dr. Jurij Krope Prof. dr. Abdul Ghani Olabi

Prof. dr. Darko Goričanec

Prof. dr. Stanislav Božičnik 
University of Maribor Press 


\title{
$10^{\mathrm{TH}}$ International Conference on Sustainable Energy and Environmental Protection
}

\author{
Energy Management and Policies
}

(June 27 ${ }^{\mathrm{TH}}-30^{\mathrm{TH}}, 2017$, Bled, Slovenia)

(Conference Proceedings)

Editors:

Emeritus Prof. dr. Jurij Krope

Prof. dr. Abdul Ghani Olabi

Prof. dr. Darko Goričanec

Prof. dr. Stanislav Božičnik 
Title: $\quad 10^{\mathrm{TH}}$ International Conference on Sustainable Energy and Environmental Protection (June $27^{\mathrm{TH}}-30^{\mathrm{TH}}, 2017$, Bled, Slovenia) (Conference Proceedings)

Subtitle: Energy Management and Policies

Editors: Emeritus Prof. Jurij Krope, Ph.D. (University of Maribor, Slovenia), Prof. Abdul Ghani Olabi, Ph.D. (University of the West of Scotland, UK), Asso. Prof. Darko Goričanec, Ph.D. (University of Maribor, Slovenia), Asso. Prof. Stanislav Božičnik (University of Maribor, Slovenia).

Review: Prof. Željko Knez, Ph.D. (University of Maribor, Slovenia), Prof. Niko Samec, Ph.D. (University of Maribor, Slovenia).

Tehnical editors : Jan Perša (University of Maribor Press), Armin Turanović (University of Maribor Press).

Design and layout: University of Maribor Press

Conference: $\quad 10^{\mathrm{TH}}$ International Conference on Sustainable Energy and Environmental Protection

Honorary Committee:

Abdul Ghani Olabi, Ph.D. (Honorary President, University of the West of Scotland, United Kingdom), Igor Tičar, Ph.D (Rector of the University of Maribor, Slovenia), Niko Samec $\mathrm{Ph} . D$. (Pro-rector of University of Maribor, Slovenia), Zdravko Kravanja, Ph-D. (Dean of the Faculty of Chemistry and Chemical Engineering, University of Maribor, Slovenia).

Organising Committee:

Jurij Krope, Ph.D. (University of Maribor, Slovenia), Darko Goričanec, Ph.D. (University of Maribor, Slovenia), Stane Božičnik, Ph.D. (University of Maribor, Slovenia), Peter Trop, Ph.D. (University of Maribor, Slovenia), Danijela Urbancl, Ph.D. (University of Maribor, Slovenia), Sonja Roj (University of Maribor, Slovenia), Željko Knez, Ph.D. (University of Maribor, Slovenia), Bojan Štumberger, Ph.D. (University of Maribor, Slovenia), Franci Čuš, Ph.D. (University of Maribor, Slovenia), Miloš Bogataj, Ph.D. (University of Maribor, Slovenia), Janez Žlak, Ph.D (Mine Trbovlje Hrastnik, Slovenia), LL. M. Tina Žagar (Ministry of Economic Development and Technology), Igor Ivanovski, MSc. (IVD Maribor, Slovenia), Nuša Hojnik, Ph.D. (Health Center Maribor).

Programme Committee:

Prof. Abdul Ghani Olabi (UK), Emeritus Prof. Jurij Krope (Slovenia), Prof. Henrik Lund (Denmark), Prof. Brian Norton (Ireland), Prof. Noam Lior (USA), Prof. Zdravko Kravanja (Slovenia), Prof. Jirí Jaromír Klemeš (Hungary), Prof. Stane Božičnik (Slovenia), Prof. Bojan Štumberger (Slovenia), Prof. Soteris Kalogirou (Cyprus), Prof. Stefano Cordiner (Italy), Prof. Jinyue Yan (Sweden), Prof. Umberto Desideri (Italy), Prof. M.S.J. Hashmi (Ireland), Prof. Michele Dassisti (Italy), Prof. Michele Gambino (Italy), Prof. S. Orhan Akansu (Turkey), Dr. David Timoney (Ireland), Prof. David Kennedy (Ireland), Prof. Bekir Sami Yilbas (Saudi Arabia), Dr. Brid Quilty (Ireland), Prof. B. AbuHijleh (UAE), Prof. Vincenc Butala (Slovenia), Prof. Jim McGovern (Ireland), Prof. Socrates Kaplanis (Greece), Dr. Hussam Jouhara (UK), Prof. Igor Tičar (Slovenia), Prof. Darko Goričanec (Slovenia), Dr. Joseph Stokes (Ireland), Prof. Antonio Valero (Spain), Prof. Aristide F. Massardo (Italy), Prof. Ashwani Gupta (USA), Dr. Aoife Foley (UK), Dr. Athanasios Megartis (UK), Prof. Francesco Di Maria (Italy), Prof. George Tsatsaronis (Germany), Prof. Luis M. Serra (Spain), Prof. Savvas Tassou (UK), Prof. Luigi Alloca (Italy), Prof. Faek Diko (Germany), Dr. F. Al-Mansour (Slovenia), Dr. Artur Grunwald (Germany), Dr. Peter Trop (Slovenia), Prof. Philippe Knauth (France), Prof. Paul Borza (Romania), Prof. Roy Douglas (UK), Prof. Dieter Meissner (Austria), Dr. Danijela Urbancl (Slovenia), Prof. Daniel Favrat (Switzerland), Prof. Erik Dahlquist (Sweden), Prof. Eric Leonhardt (USA), Prof. GianLuca Rospi (Italy), Prof. Giuseppe Casalino (Italy), Prof. J. Dawson (USA), Dr. Josè Simoes (Portugal), Prof. Kadir Aydin (Turkey), Dr. Khaled Benyounis (Ireland), Prof. Laszlo Garbai (Hungary), Prof. Mariano Martin (Spain), Prof. Masahiro Ishida (Japan), Prof. Michael Seal (USA), Prof. Marco Spinedi (Italy), Prof. Michio Kitano (Japan), Prof. Milovan Jotanović (BiH), Prof. Nafiz Kahraman (Turkey), Prof. Na Zhang (China), Prof. Naotake Fujita (Japan), Prof. Niko Samec (Slovenia), Prof. Oleksandr Zaporozhets (Ukraine), Prof. Osama Al-Hawaj (Kuwait), Prof. Petar Varbanov (Hungary), Prof. Peter Goethals (Belgium), Prof. Qi Zhang (China), Prof. Rik Baert (The Netherlands), Prof. Rolf Ritz (USA), Dr. Stephen Glover (UK), Prof. Signe Kjelstrup (Norway), Dr. Sumsun Naher (UK), Prof. Sven Andersson (Sweden), Dr. Salah Ibrahim (UK), Prof. Sebahattin Unalan (Turkey), Prof. Sabah Abdul-Wahab Sulaiman (Oman), Prof. Somrat Kerdsuwan (Thailand), Prof. T. Hikmet Karakoç (Turkey), Prof. Tahir Yavuz (Turkey), Prof. Hon Loong Lam (Thailand), LL.M. Tina Žagar (Slovenia), Prof. A.M.Hamoda (Qatar), Prof. Gu Hongchen (China), Prof. Haşmet Turkoglu (Turkey), Dr. Hussam Achour (Ireland), Dr. James Carton (Ireland), Dr. Eivind Johannes (Norway), Prof. Elvis Ahmetović (BiH), Prof. 
D.G.Simeonov (Bulgaria), Prof. Abdelakder Outzourhit (Morocco), Prof. Bilge Albayrak Çeper (Turkey), Prof. Bekir Zühtü Uysal (Turkey), Prof. D. Bradley (UK), Dr. Silvia Tedesco (UK), Dr. Valentin Ivanov (Germany), Dr. Vincent Lawlor (Austria), Prof. Yonghua Cheng (Belgium), Prof. Yasufumi Yoshimoto (Japan), Prof. Yahya Erkan Akansu (Turkey), Prof. Yunus Ali Çengel (Turkey), Prof. Zeljko Knez (Slovenia), Prof. Zoltan Magyar (Hungary), Dr. William Smith (Ireland), Dr. Abed Alaswad (UK).

First published in 2017 by

University of Maribor Press

Slomškov trg 15, 2000 Maribor, Slovenia

tel. +386225042 42, fax +38622523245

http://press.um.si, zalozba@um.si

\section{Co-published by}

University of Maribor, Faculty of Chemistry and Chemical Engineering

Smetanova ulica 17,2000 Maribor, Slovenia

tel. +386 (0)2 2294 400, faks + $386(0) 22527774$

http://www.fkkt.um.si, fkkt@um.si

Published: 5. July 2017

\section{(C) University of Maribor Press}

All rights reserved. No part of this book may be reprinted or reproduced or utilized in any form or by any electronic, mechanical, or other means, now known or hereafter invented, including photocopying and recording, or in any information storage or retrieval system, without permission in writing from the publisher.

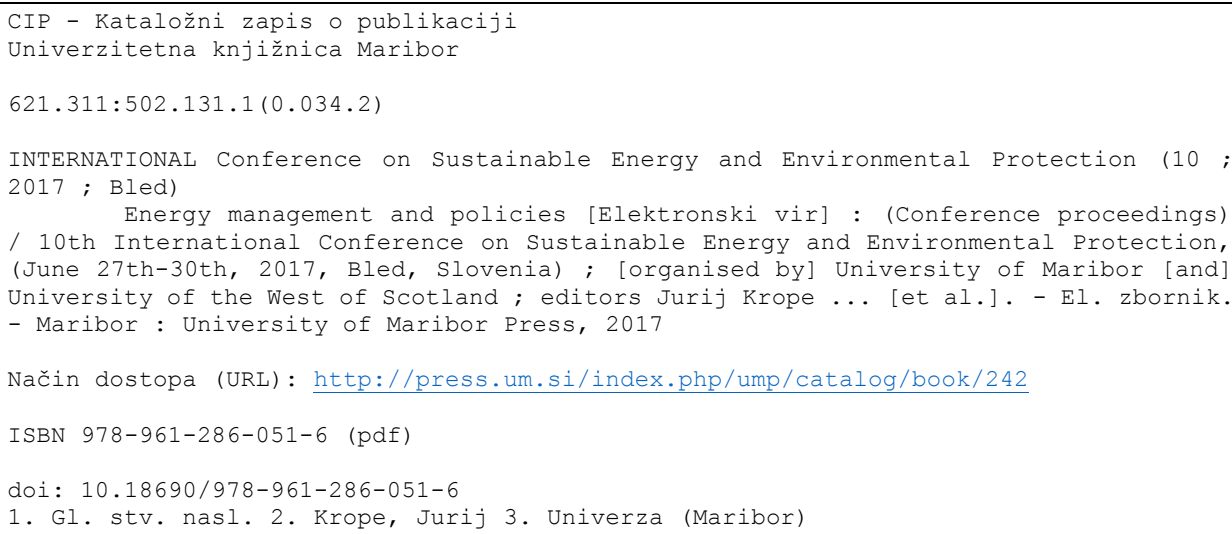

ISBN 978-961-286-051-6

DOI: https://doi.org/10.18690/978-961-286-051-6

Price: Free copy

For publisher: Prof. Igor Tičar, Ph.D., rector (University of Maribor) 
$10^{\mathrm{TH}}$ InTERNATIONAL CONFERENCE ON Sustainable ENERGy AND Environmental Protection (June 27 $7^{\mathrm{TH}}-30^{\mathrm{TH}}$, 2017, BLed, SLOVEnia), EnERgy Management ANd Policies

J. Krope, A.Ghani Olabi, D. Goričanec \& S. Božičnik

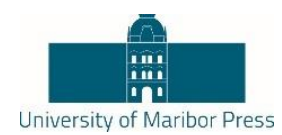

\section{Preface}

The $10^{\text {th }}$ International Conference on Sustainable Energy and environmental Protection SEEP 2017 was organised on June $27^{\text {th }}-30^{\text {th }} 2017$ in Bled, Slovenia, by:

- Faculty of Chemistry and Chemical Engineering, University of Maribor, Slovenia,

- University of the West of Scotland, School of Engineering and

The aim of SEEP2017 is to bring together the researches within the field of sustainable energy and environmental protection from all over the world.

The contributed papers are grouped in 18 sessions in order to provide access to readers out of 300 contributions prepared by authors from 52 countries.

We thank the distinguished plenary and keynote speakers and chairs who have kindly consented to participate at this conference. We are also grateful to all the authors for their papers and to all committee members.

We believe that scientific results and professional debates shall not only be an incentive for development, but also for making new friendships and possible future scientific development projects.

General chair

Emeritus Prof. dr. Jurij Krope
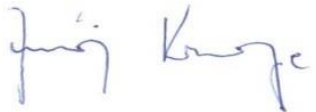
$10^{\mathrm{TH}}$ International CONFERENCE ON Sustainable ENERGY AND Environmental Protection (June 27 $7^{\mathrm{TH}}-30^{\mathrm{TH}}$, 2017, Bled, SLOVEnia), ENERgy Management AND Policies J. Krope, A.Ghani Olabi, D. Goričanec \& S. Božičnik

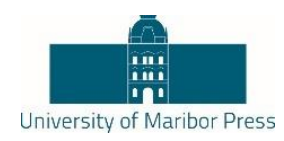

\title{
Plenary Talk on \\ The Relation between Renewable Energy and Circular Economy
}

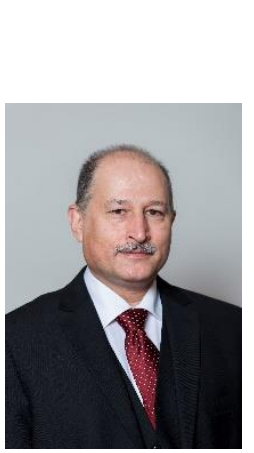

\author{
ABDUL GHANI OLABI - BIBLIOGRAPHY
}

Prof Olabi is director and founding member of the Institute of Engineering and Energy Technologies (www.uws.ac.uklieet) at the University of the West of Scotland. He received his M.Eng and Ph.D. from Dublin City University, since 1984 he worked at SSRC, HIAST, CNR, CRF, DCU and UWS. Prof Olabi has supervised postgraduate research students (10 M.Eng and 30PhD) to successful completion. Prof Olabi has edited 12 proceedings, and has published more than 135 papers in peer-reviewed international journals and about 135 papers in international conferences, in addition to 30 book chapters. In the last 12 months Prof Olabi has patented 2 innovative projects. Prof Olabi is the founder of the International Conference on Sustainable Energy and Environmental Protection SEEP, www.seepconference.co.uk

$\mathrm{He}$ is the Subject Editor of the Elsevier Energy Journal https://www.journals.elsevier.com/energy/editorial-board/abdul-ghani-olabi, also Subject editor of the Reference Module in Materials Science and Materials Engineering http://scitechconnect.elsevier.com/reference-module-material-science/ and board member of a few other journals. Prof Olabi has coordinated different National, EU and International Projects. He has produced different reports to the Irish Gov. regarding: Hydrogen and Fuel Cells and Solar Energy.

Correspondence AdDress: Abdul Ghani Olabi, Ph.D., Professor, University of the West of Scotland, School of Engineering and Computing, D163a, McLachlan Building, Paisley, United Kingdom, e-mail: Abdul.Olabi@uws.ac.uk. 
$10^{\text {TH }}$ InTERNATIONAL CONFERENCE ON Sustainable ENERGy AND

Environmental Protection (June 27 $7^{\mathrm{TH}}-30^{\mathrm{TH}}$, 2017, Bled,

SLOVEnia), EnERgy Management And Policies

J. Krope, A.Ghani Olabi, D. Goričanec \& S. Božičnik

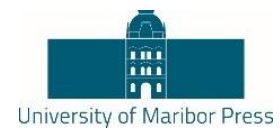

\title{
Plenary Talk on \\ Energy Footprints Reduction and Virtual Footprints Interactions
}

\author{
JIŘí JAROMÍR KLEMEŠ \& PETAR SABEV VARBANOV
}

Increasing efforts and resources have been devoted to research during environmental studies, including the assessment of various harmful impacts from industrial, civic, business, transportation and other economy activities. Environmental impacts are usually quantified through Life Cycle Assessment (LCA). In recent years, footprints have emerged as efficient and useful indicators to use within LCA. The footprint assessment techniques has provided a set of tools enabling the evaluation of Greenhouse Gas (GHG) - including $\mathrm{CO}_{2}$, emissions and the corresponding effective flows on the world scale. From all such indicators, the energy footprint represents the area of forest that would be required to absorb the GHG emissions resulting from the energy consumption required for a certain activity, excluding the proportion absorbed by the oceans, and the area occupied by hydroelectric dams and reservoirs for hydropower.

An overview of the virtual GHG flow trends in the international trade, associating the GHG and water footprints with the consumption of goods and services is performed. Several important indications have been obtained: (a) There are significant GHG gaps between producer's and consumer's emissions - US and EU have high absolute net imports GHG budget. (b) China is an exporting country and increasingly carries a load of GHG emission and virtual water export associated with consumption in the relevant importing countries. (c) International trade can reduce global environmental pressure by redirecting import to products produced with lower intensity of GHG emissions and lower water footprints, or producing them domestically.

To develop self-sufficient regions based on more efficient processes by combining neighbouring countries can be a promising development. A future direction should be focused on two main areas: (1) To provide the self-sufficient regions based on more efficient processes by combining production of surrounding countries. (2) To develop the shared mechanism and market share of virtual carbon between trading partners regionally and internationally.

CORRESPONDENCE AdDRESS: Jiř́ Jaromír Klemeš, DSc, Professor, Brno University of Technology - VUT Brno, Faculty of Mechanical Engineering, NETME Centre, Sustainable Process Integration Laboratory - SPIL, Technická 2896/2, 61669 Brno, Czech Republic, e-mail: klemes@fme.vutbr.cz. Petar Sabev Varbanov, Ph.D., Associate Professor, Brno University of Technology - VUT Brno, Faculty of Mechanical Engineering, NETME Centre, Sustainable Process Integration Laboratory - SPIL, Technická 2896/2, 61669 Brno, Czech Republic, e-mail: varbanov@fme.vutbr.cz. 
$10^{\mathrm{TH}}$ International CONFERENCE ON Sustainable ENERGY AND Environmental Protection (June 27 $7^{\mathrm{TH}}-30^{\mathrm{TH}}$, 2017, Bled, SLOVEnia), EnERgy Management ANd Policies

J. Krope, A.Ghani Olabi, D. Goričanec \& S. Božičnik

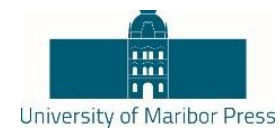

\section{JIŘÍ JAROMÍR KLEMEŠ - BIBLIOGRAPHY}

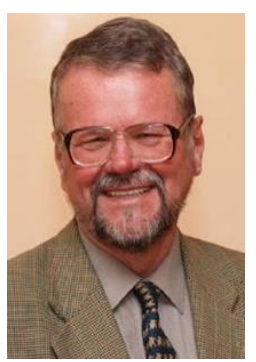

Head of "Sustainable Process Integration Laboratory - SPIL", NETME Centre, Faculty of Mechanical Engineering, Brno University of Technology - VUT Brno, Czech Republic and Emeritus Professor at "Centre for Process Systems Engineering and Sustainability", Pázmány Péter Catholic University, Budapest, Hungary.

Previously the Project Director, Senior Project Officer and Hon Reader at Department of Process Integration at UMIST, The University of Manchester and University of Edinburgh, UK. Founder and a long term Head of the Centre for Process Integration and Intensification - CPI2, University of Pannonia, Veszprém, Hungary. Awarded by the EC with Marie Curies Chair of Excellence (EXC). Track record of managing and coordinating 91 major EC, NATO and UK Know-How projects. Research funding attracted over $21 \mathrm{M€}$.

Co-Editor-in-Chief of Journal of Cleaner Production ( $\mathrm{IF}=4.959)$. The founder and President for 20 $\mathrm{y}$ of PRES (Process Integration for Energy Saving and Pollution Reduction) conferences. Chairperson of CAPE Working Party of EFCE, a member of WP on Process Intensification and of the EFCE Sustainability platform.

He authored nearly 400 papers, h-index 40. A number of books published by McGraw-Hill; Woodhead; Elsevier; Ashgate Publishing Cambridge; Springer; WILEY-VCH; Taylor \& Francis).

Several times Distinguished Visiting Professor for Universiti Teknologi Malaysia, Xi'an Jiaotong University; South China University of Technology, Guangzhou; Tianjin University in China; University of Maribor, Slovenia; University Technology Petronas, Malaysia; Brno University of Technology and the Russian Mendeleev University of Chemical Technology, Moscow. Doctor Honoris Causa of Kharkiv National University "Kharkiv Polytechnic Institute" in Ukraine, the University of Maribor in Slovenia, University POLITEHNICA Bucharest, Romania. "Honorary Doctor of Engineering Universiti Teknologi Malaysia", "Honorary Membership of Czech Society of Chemical Engineering", "European Federation of Chemical Engineering (EFCE) Life-Time Achievements Award" and "Pro Universitaire Pannonica" Gold Medal.

CORRESPONDENCE AdDRESS: Jiří Jaromír Klemeš, DSc, Professor, Brno University of Technology - VUT Brno, Faculty of Mechanical Engineering, NETME Centre, Sustainable Process Integration Laboratory - SPIL, Technická 2896/2, 61669 Brno, Czech Republic, e-mail: klemes@fme.vutbr.cz. 
$10^{\mathrm{TH}}$ InTERNATIONAL CONFERENCE ON Sustainable ENERGy AND Environmental Protection (June 27 $7^{\mathrm{TH}}-30^{\mathrm{TH}}$, 2017, BLed, SLOVEnia), EnERgy Management And Policies

J. Krope, A.Ghani Olabi, D. Goričanec \& S. Božičnik

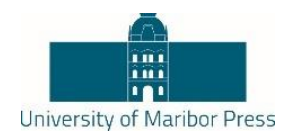

\section{Plenary Talk on Renewable energy sources for environmental protection}

\section{HAKAN SERHAD SOYHAN}

Development in energy sector, technological advancements, production and consumption amounts in the countries and environmental awareness give shape to industry of energy. When the dependency is taken into account in terms of natural resources and energy, there are many risks for countries having no fossil energy sources. Renewable and clean sources of energy and optimal use of these resources minimize environmental impacts, produce minimum secondary wastes and are sustainable based on current and future economic and social societal needs. Sun is one of the main energy sources in recent years. Light and heat of sun are used in many ways to renewable energy. Other commonly used are biomass and wind energy. To be able to use these sources efficiently national energy and natural resources policies should be evaluated together with the global developments and they should be compatible with technological improvements. Strategic plans with regard to energy are needed more intensively and they must be in the qualification of a road map, taking into account the developments related to natural resources and energy, its specific needs and defining the sources owned by countries. In this presentation, the role of supply security was evaluated in term of energy policies. In this talk, new technologies in renewable energy production will be shown and the importance of supply security in strategic energy plan will be explained.

Correspondence AdDress: Hakan Serhad Soyhan, Ph.D., Professor, Sakarya University, Engineering Faculty, Esentepe Campus, M7 Building, 54187 - Esentepe /Sakarya, Turkey, e-mail: hsoyhan@sakarya.edu.tr. 
$10^{\mathrm{TH}}$ InTERNATIONAL CONFERENCE ON Sustainable ENERGY AND Environmental Protection (June 27 $7^{\mathrm{TH}}-30^{\mathrm{TH}}$, 2017, Bled, Slovenia), Energy Management AND Policies

J. Krope, A.Ghani Olabi, D. Goričanec \& S. Božičnik

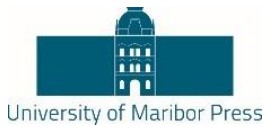

\section{HAKAN SERHAD SOYHAN - BIBLIOGRAPHY}

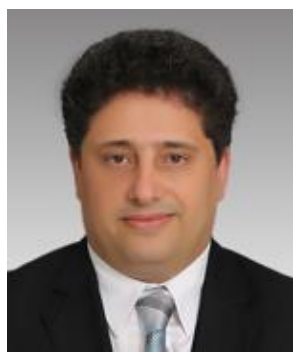

Professor at Sakarya University, Engineering Faculty. $50 \%$ fot teaching and the rest for reasearch activities.

Teaching, courses taught:

Graduate courses:

- Combustion technology;

- Modelling techniques;

Undergraduate courses:

- Combustion techniques;

- Internal combustion engines;

- Fire safety.

Tehnical skills and competences professional societies:

- 25 jurnal papers in SCI Index. 23 conference papers;

- $\quad$ Editor at FCE journal. Co-editor at J of Sakarya University;

- Head of Local Energy Research Society (YETA);

- Member od American Society of Mechanical engineers (ASME);

- Member of Turkish Society of Mechanical Engineers (TSME).

Correspondence AdDress: Hakan Serhad Soyhan, Ph.D., Professor, Sakarya University, Engineering Faculty, Esentepe Campus, M7 Building, 54187 - Esentepe /Sakarya, Turkey, e-mail: hsoyhan@sakarya.edu.tr. 

$10^{\mathrm{TH}}$ InTERnAtional CONFERENCE ON Sustainable ENERGy AND Environmental Protection (June 27 $7^{\mathrm{TH}}-30^{\mathrm{TH}}$, 2017, Bled, SLOVENIA), ENERGy MANAGEMENT AND Policies

J. Krope, A.Ghani Olabi, D. Goričanec \& S. Božičnik

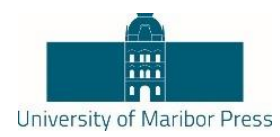

\section{Table of Contents}

\section{CONFERENCE PROCEEDINGS}

Defining Corporate Energy Policy and Strategy to Achieve Carbon Emissions Reduction in Non-Energy Intensive MultiSite Industrial Organisations

Noel Finnerty, Sergio Contreras, Raymond Sterling, Daniel Coakley \& Marcus M. Keane

A Systematic Decision Support Framework and Prioritization Method for Energy Projects in Industrial Organisations

Sergio Contreras, Noel Finnerty, Raymond Sterling, Daniel Coakley \& Marcus M. Keane

Energy Management System Standard Implementation at

Yasar University in Izmir, Turkey: From Iso 50001 to Practice

Hacer Sekerci, Nurdan Yildirim \& Arif Hepbasli

Long Term Energy Strategy Scenario to Promote 'Green' Electricity Against Natural Gas Consumption

Cristina Tarean

A Hybrid Solar/Wind/Biofuel Management Strategy in Iran

Using Techno-Econo-Socio-Environmental Multivariate Analysis (TESEMA)

Pouya Ifaei, Jouan Rashidi, Jeong Tai Kim \& ChangKyoo Yoo

The Impact of the European Electricity Market Regulation on

Environmental Adjusted Productivity: Evidence from 10

Selected Countries Between 1995 and 2013

Teodora Diana Corsatea

Energization as a Determinant of Life Quality in the Dispersed Rural Areas in Colombia Andrés Felipe León Esteban, Isaac Guerrero Rincón, Viatcheslav Kafarov \& Alexandra Cortés Aguilar 
Impact of Dynamic Pricing Mechanism on Net Metered

Jagruti Thakur \& Basab Chakraborty

Comparison of Farmers' Risk Perception in Staw Supply

Lingling Wang \& Tsunemi Watanabe

Patterns of Energy Consumption, GDP and CO2 Emissions in

China

Bing Gong, Qing Guo, Joaquín Ordieres-Meré \& Xiaochen Zheng

Multi-Criteria Approach to Sustainability Evaluate of

District Heating System Scenarios in Case of Serbia

Marina Jovanović, Vukman Bakić, Valentina Turanjanin \& Biljana Vučićević

Policies and Measures for Sustainable and Energy Efficient Urban Freight Transport

Tomislav Letnik, Giuseppe Luppino, Andrea Bardi \& Stane Bozicnik 
$10^{\mathrm{TH}}$ InTERnational CONFERENCE ON Sustainable ENERgy AND

ENVIRONMENTAL Protection (June $27^{\mathrm{TH}}-30^{\mathrm{TH}}$, 2017, Bled, SLOVENIA), ENERGy MANAGEMENT AND Policies

J. Krope, A.Ghani Olabi, D. Goričanec \& S. Božičnik

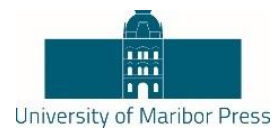

\title{
Defining Corporate Energy Policy and Strategy to Achieve Carbon Emissions Reduction in Non-Energy Intensive Multi-Site Industrial Organisations
}

\author{
NoEl Finnerty, SERGio CONTRERAS, RAYMOND STERling, DANIEL COAKLEY \& \\ MARCUS M. KEANE
}

\begin{abstract}
Research on the components and characteristics of long-term energy policy and strategies in large organisations is limited. Non-energy intensive multinationals do not face the environmental regulations required by their energy intensive counterparts, further widening the "energy efficiency gap" due to missed opportunities. This work investigates the development of long-term energy policy and associated strategy for nonenergy intensive multi-site organisations via a systematic literature review identifying essentials of energy policy, strategy and associated barriers/drivers to energy efficiency. Highlights include a review of energy policy guidelines and standards, an analysis of the parameters influencing decision-making practices, including the non-energy benefits of energy efficiency investments and a study of 6 top-ranked sustainable global companies to identify best-practices. Subsequently, this work proposes a methodology to formulate 'corporate energy policy and strategy' for nonenergy intensive industries. A case study is presented with findings on initial deployment in a Fortune 500 multinational.
\end{abstract}

Keywords: • energy policy • energy strategy • ISO 50001 • non-energy intensive $\bullet$ multinational $\bullet$

Correspondence Address: Noel Finnerty, Boston Scientific Corporation, Ballybrit Business Park, Galway, Ireland, email: Noel.Finnerty@bsci.com. Sergio Contreras, College of Engineering and Informatics, IRUSE, Ryan Institute, NUI, Galway, Ireland, email: sdcontrerasg@gmail.com. Raymond Sterling, PhD, Researcher, College of Engineering and Informatics, IRUSE, Ryan Institute, NUI, Galway, Ireland, email: raymond.sterling@nuigalway.ie. Daniel Coakley, PhD, College of Engineering and Informatics, IRUSE, Ryan Institute, NUI, Galway, Ireland, email: danielcoakley1@gmail.com. Marcus M. Keane, Lecturer, College of Engineering and Informatics, IRUSE, Ryan Institute, NUI, Galway, Ireland, email: Marcus.keane@ nuigalway.ie.

https://doi.org/10.18690/978-961-286-051-6.1

ISBN 978-961-286-051-6

(C) 2017 University of Maribor Press

Available at: http://press.um.si. 

POLICIES

N. Finnerty, S. Contreras, R. Sterling, D. Coakley \& M. M. Keane: Defining Corporate Energy Policy and Strategy to Achieve Carbon Emissions Reduction in Non-Energy Intensive Multi-Site Industrial Organisations

Industrial firms struggle to make positive investment decisions on energy efficiency projects even when they are financially viable, contribute to lessen their impact on the environment and even provide additional non-energy benefits. This sub-optimal level is referred to in literature as the "energy efficiency gap" [1]. It is a consequence of the interaction between energy efficiency barriers and drivers that affect a firm's decision making processes.

Empirical research shows that energy efficiency barriers affect small, medium and large manufacturing companies, and that the impact on non-energy intensive ${ }^{1}$ firms is greater than on the energy intensive ones [2]. Since energy costs are a small fraction of production costs in non-energy intensive companies, energy efficiency is given less importance. Moreover, as energy efficiency may not be closely related to the core business activities, it could also be treated as non-strategic, leading to lack of top management involvement, competition for funding with other "more important" investments, limited resources and an unstructured decision making process [3].

Different drivers stimulate enterprises to find and execute investments in energy efficiency. These drivers can be internal or external to the firm and include, reduction of production costs, compliance with environmental regulations on energy efficiency and $\mathrm{CO}_{2}$ emissions or an improved sustainability record. Non-energy intensive organizations are not required to meet the strict environmental regulations required by their energy intensive counterparts, however, due to their size and revenue volumes, they are subject to high public exposure through corporate sustainability rankings making them an interesting focus group in terms of energy policy and strategy formulation. However, drivers are ineffective to overcome barriers if companies do not practice energy management and lack long term energy strategies and appropriate energy management systems [1], [2].

This study identifies the essential components of a corporate energy policy and proposes an approach to formulate the supporting energy strategies to enable non-energy intensive firms meet energy and carbon reduction goals.

\section{Literature Review}

In large organisations, energy policy is typically associated with an internal energy strategy. Although, a long-term energy strategy is a fundamental driver for energy-related issues, research about essential components and characteristics of such a corporate strategy are rare. An study in Sweden, found that the majority of the studied firms did not have an energy strategy or had a short-term one ( $<3$ years) [1]. Also in Sweden, it has been found that long-term energy strategies of more than three years are more frequent in large firms than in small ones [4]. It is expected that an energy strategy helps to create, 
$10^{\mathrm{TH}}$ INTERNATIONAL CONFERENCE ON SUSTAINABLE ENERGY AND ENVIRONMENTAL Protection (June $27^{\mathrm{TH}}-30^{\mathrm{TH}}, 2017$, Bled, Slovenia), ENERgy MANAGEMENT AND

POLICIES

N. Finnerty, S. Contreras, R. Sterling, D. Coakley \& M. M. Keane: Defining Corporate

Energy Policy and Strategy to Achieve Carbon Emissions Reduction in Non-Energy Intensive Multi-Site Industrial Organisations

maintain, or develop a firm's competitive advantage by increasing value, reducing costs and reducing risks associated with energy issues [3]. Finally, to the best of our knowledge, peer reviewed literature on corporate energy policy and supporting energy strategy is scarce, to date, no research has been conducted for non-energy intensive multinationals.

\subsection{Main barriers to energy efficiency}

Since 1998 empirical studies have provided evidence about the barriers that prevent costeffective energy efficiency projects from being executed in manufacturing firms. Previous research revealed that barriers vary according to both the characteristics of the firm (e.g. size, energy intensity and sector) and the energy efficiency measure (e.g. production disruption, implementation and technical requirements).

Low capital availability is a recurring and relevant economic obstacle for energy efficiency investments, but, in large firms, it can be considered because of the low priority of energy efficiency. This low priority reveals companies strategic view on energy efficiency [5]. In fact, while access to external funding and lack of own capital are reported as causes for this barrier in SME's [6][7], opportunity costs and allocation of capital to other non-energy projects might be the reason in large enterprises [8].

Risk of production disruptions are regarded as a critical barrier in both non-energy intensive [9] [10] and energy intensive firms [11].

Lack of awareness, governmental initiatives, and time to implement energy efficiency are also identified barriers [10], [2], [6], [12].

\subsection{Main drivers to energy efficiency}

Reduction of energy costs is perceived as the most important driver for energy efficiency but it might not be enough motivation to adopt energy conservation measures if energy is given low-priority within the organisation [5], [13].

The existence of a long-term energy strategy and ambitious people within an organisation is one of the top drivers for adoption of energy efficiency measures [9], [11], [14].

Awareness of the non-energy benefits related to an energy efficiency investment, those that affect the production cost, and including them into the financial evaluation can also lead to more favourable assessments [15]. Energy efficiency projects can be successfully sold to management if rather than the usual financial approach a strategic approach is taken [5] by using non-energy benefits to emphasise its contribution to enhance a firm's competitive advantage. 
N. Finnerty, S. Contreras, R. Sterling, D. Coakley \& M. M. Keane: Defining Corporate Energy Policy and Strategy to Achieve Carbon Emissions Reduction in Non-Energy Intensive Multi-Site Industrial Organisations

However, industry "do not seem to have yet acknowledged how relevant non-energy benefits are to promote energy efficiency measures adoption" [2], and "lack of knowledge of how these [non-energy benefits] should be quantified and monetised" [16].

\subsection{Decision-making practices in manufacturing firms}

The investment decision process plays a definitive role in the selection and implementation of energy efficiency measures in manufacturing firms. The decisionmaking practices are influenced by diverse internal factors surrounding the evaluation process (e.g. criteria selection), the financial assessment (e.g. fiscal rules on payback period and methods used) and the investment parameters such as categorisation, size and complexity. In addition, external and cultural factors also shape decision-making processes. "Profitability plays an important but not decisive role in investment decisionmaking" [12], the rest of the decision is related to, for example, strategic character of investment, company culture and knowledge of non-energy benefits or lack of information about contracts with third party companies (e.g. ESCOs or fuel suppliers).

\subsection{Non-energy benefits of energy efficiency investments}

Non-energy benefits are mainly related to positive impacts on productivity such as lower maintenance costs and improved public image.

Benefits such as reduced labour and maintenance costs can be monetised to construct compelling business cases with higher savings and better financial metrics than those accounting for lower energy consumption alone [17]. The average payback period from a sample of projects was reduced from 4.2 to 1.9 years when the contribution of productivity related benefits was monetised [15].

Non-energy benefits are considered as essential components of the business case and profitability of energy efficiency investments. Two main reasons are identified. First, by connecting non-energy benefits and their contribution to improve a firm's competitive advantage imprints a strategic character to these investments. Second, the potential of non-energy benefits to increase the profitability of energy efficiency projects.

\subsection{Energy policy guidelines from international standards}

ISO-50001 [18], ENERGY STAR ${ }^{\mathrm{TM}}$ [19], and SEPTM [20] standards recognise that energy policy is fundamental to set the direction and drive energy performance improvement through the implementation of energy management systems. These standards converge in defining energy policy as top management's official commitment to improve energy performance in an organisation. However, none provides a step by step guide to policy formulation and associated supporting strategies. 
$10^{\mathrm{TH}}$ INTERNATIONAL CONFERENCE ON SUSTAINABLE ENERGY AND ENVIRONMENTAL Protection (June $27^{\mathrm{TH}}-30^{\mathrm{TH}}, 2017$, Bled, Slovenia), ENERgy MANAGEMENT AND

POLICIES

N. Finnerty, S. Contreras, R. Sterling, D. Coakley \& M. M. Keane: Defining Corporate

Energy Policy and Strategy to Achieve Carbon Emissions Reduction in Non-Energy Intensive Multi-Site Industrial Organisations

\subsection{Industry best practices on corporate energy policy}

Companies voluntarily participate in sustainability ranking processes via surveys [21][23] aimed at recognition as leading performers in sustainability. The outcome of these rankings is followed by investors that direct resources towards top ranked enterprises [23]-[25]. Top ranked sustainable companies are a source of best practices in energy performance improvement. Since part of the ranking criteria relate to energy performance, their sustainability assessments cover energy related issues. Six non-energy intensive corporations were studied. They are recognised leaders in sustainability in their industry sector.

An analysis of the energy policy practices that are being applied by the six corporations, including information found in the Carbon Disclosure Project, is used to identify best practices on energy policy. Findings are:

- Hierarchy within the organisation: embedded into or dependent on the Corporate Sustainability Policy.

- Justification: Alignment to relevant climate change efforts (e.g. Paris Agreement [26]);

- Carbon emission scope covered by energy policy: Scopes 1, 2 or 3 of the Green House Gas Protocol [27];

- Duration: Two main deadlines identified: $100 \%$ RES electricity by 2020 ; $80 \%-100 \%$ emissions reduction by 2050 ;

- Targets: Separate energy from $\mathrm{CO}_{2}$ targets:

- Energy: Source all electricity from RES (medium term) and all energy from RES (long term);

- Carbon: carbon positive or carbon neutral;

- Target setting methods: 'Scientific based'.

- Common strategies for targets achieving: Promotion of energy efficient manufacturing; Use of renewable energy; Dedicated budget for energy and carbon reduction projects; Monetary reward for managers linked to targets' achievement; and Membership to industry advocacy initiatives.

- Other strategies: ISO-50001 implementation, favourable ROI requirement for energy/carbon reduction projects, operation in 'green' certified buildings, new facilities aligned to high energy efficiency standards.

None of the six top ranked corporations uses an internal price for carbon to drive investments in energy performance improvements that reduce carbon emissions. In addition, only one corporation uses carbon offsets to neutralise its global carbon emissions and another has set a goal to reach a carbon positive state. 

POLICIES

N. Finnerty, S. Contreras, R. Sterling, D. Coakley \& M. M. Keane: Defining Corporate Energy Policy and Strategy to Achieve Carbon Emissions Reduction in Non-Energy Intensive Multi-Site Industrial Organisations

This section proposes a methodology for the definition of a corporate energy policy (Why) and the development of an associated corporate energy strategy (How) to deliver on the vision and goals set out (What) in the proposed policy.

\subsection{Corporate energy policy}

The corporate energy policy is part of the organisation's sustainability policy or plan to improve environmental performance.

An energy policy establishes top management's direction regarding energy issues in the long-term, emphasizes top management's support to energy management and contains goals such as reduction of energy usage and implementation of energy management systems [1].

The energy policy will document the justification for pursuing performance improvements and will ensure organisation's top-level commitment to achieve carbon emissions reduction targets. The policy should remove the barriers and build on the drivers identified in section 2 .

Based on the identified best-practices, Figure 1 summarises the process for developing and implementing a corporate energy policy.

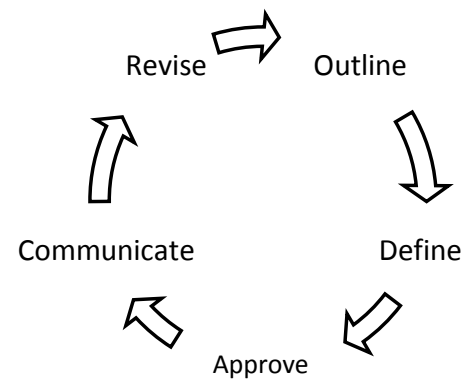

Figure 1. Energy Policy Process.

Outline: a single, easy to read yet comprehensive statement is needed to outline the corporate energy policy. This statement is the first commitment of the organisation towards improving its performance and is also a key communication piece for disseminating the policy. The statement must at least show a clear performance improvement goal and deadline for achievement (e.g. carbon neutrality by 2030). 
$10^{\mathrm{TH}}$ INTERNATIONAL CONFERENCE ON SUSTAINABLE ENERGY AND ENVIRONMENTAL Protection (June $27^{\mathrm{TH}}-30^{\mathrm{TH}}, 2017$, Bled, Slovenia), ENERgy MANAGEMENT AND

POLICIES

N. Finnerty, S. Contreras, R. Sterling, D. Coakley \& M. M. Keane: Defining Corporate

Energy Policy and Strategy to Achieve Carbon Emissions Reduction in Non-Energy Intensive Multi-Site Industrial Organisations

Define: the next step is to define the constitutive elements of the corporate energy policy. The corporate energy policy must at a minimum:

- Be aligned with the organisation's nature and strategic direction of the corporate sustainability plan;

- Reflect the organisation's long term vision in energy performance and carbon emissions (e.g. Alignment with global climate change efforts such as the Paris Agreement);

- Clearly define what is within the scope of the performance targets set as defined by the Greenhouse Gas Protocol [28];

- Engage and commit top-management to the implementation of the vision;

- Commit to the development of a roadmap to achieve the long-term vision (energy strategy section 3.2);

- Establish performance improvement as a priority and align individual sites to it;

- Reflect the commitment to provide the necessary resources to achieve the vision;

- Be documented;

- Commit to internal and external communication of its goals and achievements;

- Enact a periodic review and update process.

Approve: since the energy policy presents a clear and sometimes aggressive commitment to achieving improved performances, it is paramount that it is approved and endorsed by top-management.

Communicate: the energy policy must articulate and disseminate, through a common language, its commitment to employees, shareholders, the community and (internal/external) stakeholders.

Revise: revise the energy policy document periodically to ensure its alignment with the corporate sustainability plan and updated global performance improvement efforts.

\subsection{Corporate energy strategy}

The corporate energy strategy should define the targets, roadmap and enablers required to meet the long-term targets that ultimately deliver the long-term vision committed to by policy.

\section{Set 'SMART' Targets}

While the policy defines the long-term vision and associated boundary conditions (GHG protocol), best practice indicates that a staged approach to reaching the vision through 
N. Finnerty, S. Contreras, R. Sterling, D. Coakley \& M. M. Keane: Defining Corporate Energy Policy and Strategy to Achieve Carbon Emissions Reduction in Non-Energy Intensive Multi-Site Industrial Organisations

long term target setting is optimal. Definition of targets is suggested to follow the 'SMART' approach [29]: Scientific based, Measurable, Attainable, Relevant and Time bound. It is recommended to separate energy and carbon targets as follows:

- $\mathrm{P} \%$ renewable electricity by $20 \mathrm{YY}$ (medium term);

- $\mathrm{Q} \%$ renewable energy by $20 \mathrm{ZZ}$ (long term);

- $\mathrm{R} \% \mathrm{CO}_{2}$ reduction by $20 \mathrm{WW}$ (medium term);

- Carbon neutral/positive by 20TT (long term).

\section{Energy Strategy Roadmap}

The proposed roadmap is referred to as $\mathrm{C}^{3}$. It stands for $\mathbf{C u t}$, Convert and Compensate. It is aligned to the long-term target performance requirements.

Cut energy use: continuous pursuit of increased energy efficiency at a site level through EEM's (Energy Efficiency Measures).

Convert to renewables: through a procurement strategy and its generation on site.

Compensate unavoidable $\mathrm{CO}_{2}$ emissions: purchase off-setting certificates, through projects 'in country' where possible.

It is worth noting whilst all three strands of the roadmap can be developed in parallel it is envisaged that the implementation of 'Compensate' commences when the 'Cut' \& 'Convert' initiatives are mature.

\section{Energy Strategy Enablers}

To advance the $\mathrm{C}^{3}$ roadmap and meet the targets outlined ultimately requires investment. The literature review highlights the gaps that currently exist in the ad-hoc decisionmaking practices. To ensure optimal investment a 'Decision Support Framework' (DSF) is needed to allow top management unbiased visibility to all potential EEM's from any site [30].

The $\mathrm{C}^{3}$ roadmap is underpinned by several enablers that provide critical inputs from management teams. The following paragraphs outline the key areas supported by enablers;

Decision making process: requires defining the project selection criteria to use (e.g. financial, sustainability and business continuity criteria) and the appropriate mechanism to quantify (monetise if possible) all associated non-energy related benefits. The strategic input is from top management and it is fed into the DSF. Assigning a value to "non-energy related benefits' needs to include the impact to the sustainability targets set (e.g. using 
$10^{\mathrm{TH}}$ INTERNATIONAL CONFERENCE ON SUSTAINABLE ENERGY AND ENVIRONMENTAL Protection (June $27^{\mathrm{TH}}-30^{\mathrm{TH}}, 2017$, Bled, Slovenia), ENERgy MANAGEMENT AND

POLICIES

N. Finnerty, S. Contreras, R. Sterling, D. Coakley \& M. M. Keane: Defining Corporate

Energy Policy and Strategy to Achieve Carbon Emissions Reduction in Non-Energy Intensive Multi-Site Industrial Organisations

carbon pricing) as well as those related to improved business reliability and reduced maintenance. Such approach helps formulate a compelling business cases by effectively communicating the link between energy improvement projects and core business activities. This is a vital stage in the process of 'levelling the playing field' between energy and other company investments. Firstly, as defining the selection criteria enables energy projects compete independently from other business related projects. Secondly, if there is no dedicated energy budget it is imperative that all non-energy benefits are accounted for to optimise the business case.

Investment Strategy: top management and the finance department are key players. Ideally a dedicated budget is set-aside for $\mathrm{C}^{3}$ implementation. Even if this is not always feasible, an investment roadmap is required to deliver the strategy and policy targets. Direction is needed on the preferred company funding mechanism (e.g. own company capital vs. power purchase agreements (P.P.A)) and on financial rules relating to payback parameters such as NPV, IRR, and RoI. The strategy needs to recognise the special features that typical energy projects exhibit (e.g. long payback times). It is recommended to fix future energy forecasting based on a set period of past performance for each site in the network. Agreement on the financial equivalent of a production disruption period (recommended one hour) is required to monetise the potential impact or improvement on business continuity associated with an EEM. Establishing accountability and links between management remuneration and energy performance targets is also recommended.

Energy management system support: initiatives driven by an energy management system are enabled by strategic energy management decisions. For example: energy audit frequency and intensity level, energy management maturity models and yearly progression targets, alignment to independent certification bodies (e.g. LEED and ISO50001 ) to ensure best practices, alignment to industry advocacy initiatives (e.g. CDP and RE100) for recognition of progress and achievements and, communication strategies (internal and external).

\section{Verify: Metrics and monitoring}

Key performance indicators (KPI) are required to track performance at an individual site and organisation level to meet policy targets. The KPI are designed to capture both quantitative (e.g. energy usage) and qualitative (e.g. energy management maturity) metrics.

\section{Promote and disseminate the strategy}

Investment in EEM is improved by effectively communicating the link between EEM and core business activities. Alignment of policy and strategy reporting to the 'Global 
$10^{\mathrm{TH}}$ INTERNATIONAL CONFERENCE ON SUSTAINABLE ENERGY AND ENVIRONMENTAL Protection (June 27 $7^{\mathrm{TH}}-30^{\mathrm{TH}}, 2017$, Bled, Slovenia), EnERgy MANAGEMENT AND POLICIES

N. Finnerty, S. Contreras, R. Sterling, D. Coakley \& M. M. Keane: Defining Corporate Energy Policy and Strategy to Achieve Carbon Emissions Reduction in Non-Energy Intensive Multi-Site Industrial Organisations

Reporting Initiatives' [31] is recommended to facilitate benchmarking and sustainability mapping from organisation's sustainability reports.

\section{$4 \quad$ Case study}

GEMS (Global Energy Management System) [30] is a methodology designed between Boston Scientific Corporation (BSC) and the National University of Ireland, Galway (NUIG) aimed to guide multi-site organisations to meet energy reduction and GHG targets. GEMS complements each individual site's energy management system regardless of maturity level. GEMS is being rolled out in BSC which is a non-energy intensive multi-national manufacturing corporation in the life sciences industry.

\subsection{GEMS introduction}

The GEMS methodology [30] results in a simplified, understandable, systematic, repeatable and scalable decision support framework addressing the complexities unique to decision-making on capital investments in global multi-site organisation. The GEMS methodology is based on three foundation elements and four pillars as outlined in Figure 2.

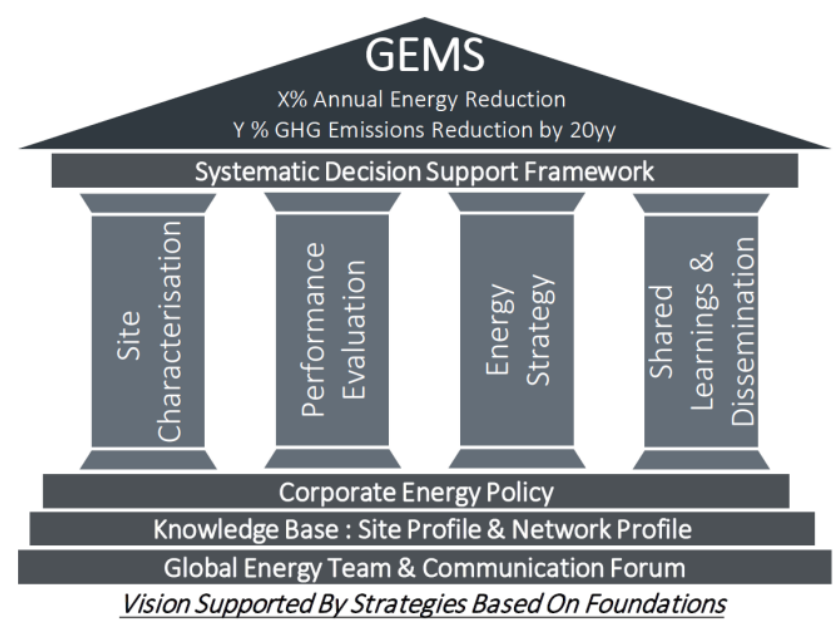

Figure 2. GEMS overview

The GEMS methodology is ideally positioned to implement a corporate energy policy (foundation) and associated energy strategy (pillar) as outlined in section 3. 
$10^{\mathrm{TH}}$ INTERNATIONAL CONFERENCE ON SUSTAINABLE ENERGY AND ENVIRONMENTAL Protection (June $27^{\mathrm{TH}}-30^{\mathrm{TH}}, 2017$, Bled, SLOVEniA), ENERGy MANAGEMENT AND

POLICIES

N. Finnerty, S. Contreras, R. Sterling, D. Coakley \& M. M. Keane: Defining Corporate

Energy Policy and Strategy to Achieve Carbon Emissions Reduction in Non-Energy Intensive Multi-Site Industrial Organisations

\subsection{GEMS energy policy foundation}

BSC (GEMS) energy policy forms part of the corporate sustainability policy and represents top management's commitment to drive and fund optimal network energy performance and reduce carbon emissions across all its sites in support of global efforts aligned to the Paris Agreement on climate change. The policy was outlined and defined by the global energy manager and has been approved by top-management.

BSC's boundary is Scope 1 and Scope 2 Emissions as defined by the GHG Protocol.

BSC will document GEMS in its 2016 sustainability report which is distributed internally and externally to all relevant stakeholders, apart from being publicly accessible through BSC webpage. The energy policy is reviewed and updated (if required) annually.

\subsection{GEMS energy strategy pillar}

\section{'SMART' Targets}

BSC has set the following target:

- 35\% reduction in $\mathrm{CO}_{2}$ by 2019 compared to 2009 baseline;

Note: Under GEMS renewable electricity, renewable energy and carbon neutral or positive targets are under review.

\section{Energy Strategy Roadmap}

Using GEMS as the framework, the 'Energy Strategy' pillar navigates the roadmap to potential carbon neutrality using the $\mathrm{C}^{3}$ approach.

Cut energy use: under the governance of GEMS, in 2016 alone BSC invested over US $\$ 5$ million into strategic energy infrastructure yielding US $\$ 2.25$ million in long term operational annual savings and reducing $\mathrm{CO}_{2}$ emissions by over $4 \%\left(3,866 \mathrm{t}\right.$ of $\mathrm{CO}_{2 \text {-eq }}$ emissions avoided).

Convert to renewables: this is a high-impact low-cost approach, BSC is currently reviewing all existing energy provider contracts to assess potential for supply from renewable sources.

Compensate unavoidable $\mathrm{CO}_{2}$ : $\mathrm{BSC}$ will review implementation of Carbon off-set projects when the 'Cut' and 'Convert' initiatives are mature. 

POLICIES

N. Finnerty, S. Contreras, R. Sterling, D. Coakley \& M. M. Keane: Defining Corporate Energy Policy and Strategy to Achieve Carbon Emissions Reduction in Non-Energy Intensive Multi-Site Industrial Organisations

\section{Energy Strategy Enablers}

Decision-making process: under GEMS, BSC implemented a DSF as the cornerstone of the decision-making strategy where operation savings, sustainability targets and business continuity are part of the assessment criteria [32]. It is worth noting the NPV on a high impact EEM (Tri Generation plant) increased by $40 \%$ when all the non-energy benefits were accounted for. These included cost avoidance of $\mathrm{CO}_{2}$ emissions, reduced running costs and maintenance of exiting HVAC equipment and business continuity improvements. The impact of a specific EEM on the overall company and site sustainability target is listed in the DSF results despite being already implicit via internal carbon pricing; such is the qualitative nature of the carbon emissions performance.

Investment strategy: BSC has proposed a dedicated fund to support their long-term goals (calculated as internal carbon pricing times their carbon emissions times multiple year payback periods). This creates good practice and aligns to the 'Cut' phase of the $\mathrm{C}^{3}$ roadmap. Both, company capital and PPA are used in their strategy, with PPA model typically used for longer term returns. NPV and IRR are fundamental financial metrics for project assessment. Future energy forecasting is based on the associated sites previous 5 year historical trends unless exceptional circumstances applies. Production disruption period of 1 hour is agreed on a site by site basis proportional to the overall value of the site value of production.

Energy management system Support: The GEMS energy audit and energy maturity level parameters are set by the Global Energy Management Team. BSC has eleven LEED certified buildings including platinum for their global headquarters. BSC main distribution centre in Quincy, US, is ENERGY STAR certified. In 2016, the 'Newsweek Green Ranking' listed BSC in $21^{\text {st }}$ position in the US, an improvement of 8 places from 2015.

\section{Verify: Metrics and monitoring}

GEMS utilises six enterprise level KPI's to track performance at an individual site and Global level as follows; Energy usage, energy management maturity level, green real estate, carbon footprint, green energy, cleaner energy.

\section{Promote and disseminate the strategy}

GEMS utilises a dedicated pillar to perform all aspects of "shared learning and dissemination'. GEMS logo and tag-line 'At BSC patient care begins with Planet care" are direct outcomes of this pillar. 
$10^{\mathrm{TH}}$ INTERNATIONAL CONFERENCE ON SUSTAINABLE ENERGY AND ENVIRONMENTAL 13 Protection (June $27^{\mathrm{TH}}-30^{\mathrm{TH}}, 2017$, Bled, Slovenia), ENERgy MANAGEMENT AND

POLICIES

N. Finnerty, S. Contreras, R. Sterling, D. Coakley \& M. M. Keane: Defining Corporate

Energy Policy and Strategy to Achieve Carbon Emissions Reduction in Non-Energy Intensive Multi-Site Industrial Organisations

\section{Conclusions and Future work}

The methodology outlined contains the key components of a long term corporate energy policy and strategic roadmap to address the barriers and support the drivers identified in the literature review. The energy strategy helps reduce the gaps identified in the literature around decision making practices and the non-energy benefits. Both policy and strategy build on best practices identified from recognised leaders in sustainability within their industry sector.

Future work will focus on evolving the methodology to enable further deployment in other organisations.

\section{Acknowledgements}

This publication has emanated from research supported in part by a research grant from Science Foundation Ireland (SFI) under Grant Number SFI/12/RC/2289 through a TP agreement between the SFI Centre for Ireland's Big Data and Analytics Research, ZuTec Inc. Ltd and Boston Scientific Corporation.

\section{Notes}

1 In non-energy intensive organisation, energy costs are $<2 \%$ of the turnover or $<5 \%$ of production costs [2], [9].

\section{References}

[1] P. Thollander and M. Ottosson, "Energy management practices in Swedish energyintensive industries," J. Clean. Prod., vol. 18, no. 12, pp. 1125-1133, Aug. 2010.

[2] A. Trianni, E. Cagno, and S. Farné, "Barriers, drivers and decision-making process for industrial energy efficiency: A broad study among manufacturing small and medium-sized enterprises," Appl. Energy, vol. 162, pp. 1537-1551, Jan. 2016.

[3] C. Cooremans, "Make it strategic! Financial investment logic is not enough," Energy Effic., vol. 4, no. 4, pp. 473-492, 2011.

[4] J.-C. Brunke, M. Johansson, and P. Thollander, "Empirical investigation of barriers and drivers to the adoption of energy conservation measures, energy management practices and energy services in the Swedish iron and steel industry," J. Clean. Prod., vol. 84, pp. 509525, Dec. 2014.

[5] C. Cooremans, "Investment in energy efficiency: do the characteristics of investments matter?," Energy Effic., vol. 5, no. 4, pp. 497-518, Nov. 2012.

[6] E. Cagno and A. Trianni, "Evaluating the barriers to specific industrial energy efficiency measures: an exploratory study in small and medium-sized enterprises," J. Clean. Prod., vol. 82, pp. 70-83, Nov. 2014.

[7] A. Trianni, E. Cagno, P. Thollander, and S. Backlund, "Barriers to industrial energy efficiency in foundries: a European comparison," J. Clean. Prod., vol. 40, pp. 161-176, Feb. 2013. 
$10^{\text {TH }}$ INTERNATIONAL CONFERENCE ON SUSTAINABLE ENERGY AND ENVIRONMENTAL Protection (June $27^{\mathrm{TH}}-30^{\mathrm{TH}}, 2017$, Bled, Slovenia), Energy Management And POLICIES

N. Finnerty, S. Contreras, R. Sterling, D. Coakley \& M. M. Keane: Defining Corporate Energy Policy and Strategy to Achieve Carbon Emissions Reduction in Non-Energy Intensive Multi-Site Industrial Organisations

[8] G. R. Timilsina, G. Hochman, and I. Fedets, "Understanding energy efficiency barriers in Ukraine: Insights from a survey of commercial and industrial firms," Energy, vol. 106, pp. 203-211, Jul. 2016.

[9] P. Rohdin and P. Thollander, "Barriers to and driving forces for energy efficiency in the non-energy intensive manufacturing industry in Sweden," Energy, vol. 31, no. 12, pp. 1836-1844, Sep. 2006.

[10] A. Hasanbeigi, C. Menke, and P. du Pont, "Barriers to energy efficiency improvement and decision-making behavior in Thai industry," Energy Effic., vol. 3, no. 1, pp. 33-52, Mar. 2010.

[11] P. Thollander and M. Ottosson, "An energy efficient Swedish pulp and paper industry exploring barriers to and driving forces for cost-effective energy efficiency investments," Energy Effic., vol. 1, no. 1, pp. 21-34, Feb. 2008.

[12] G. R. Timilsina, G. Hochman, and I. Fedets, "Understanding energy efficiency barriers in Ukraine: Insights from a survey of commercial and industrial firms," Energy, vol. 106, pp. 203-211, Jul. 2016.

[13] H. L. F. de Groot, E. T. Verhoef, and P. Nijkamp, "Energy saving by firms: decisionmaking, barriers and policies," Energy Econ., vol. 23, no. 6, pp. 717-740, Nov. 2001.

[14] P. Rohdin, P. Thollander, and P. Solding, "Barriers to and drivers for energy efficiency in the Swedish foundry industry," Energy Policy, vol. 35, no. 1, pp. 672-677, Jan. 2007.

[15] E. Worrell, J. A. Laitner, M. Ruth, and H. Finman, "Productivity benefits of industrial energy efficiency measures," Energy, vol. 28, no. 11, pp. 1081-1098, 2003.

[16] T. Nehler and J. Rasmussen, "How do firms consider non-energy benefits? Empirical findings on energy-efficiency investments in Swedish industry," J. Clean. Prod., vol. 113, pp. 472-482, Feb. 2016.

[17] M. Pye and A. McKane, "Making a stronger case for industrial energy efficiency by quantifying non-energy benefits," Resour. Conserv. Recycl., vol. 28, no. 3-4, pp. 171-183, 2000.

[18] ISO, "ISO 50001:2011 - Energy management systems - Requirements with guidance for use." p. 16, 2011.

[19] US EPA, ENERGY STAR Guidelines for Energy Management Overview. U.S. Environmental Protection Agency, 2013.

[20] US Department of Energy, "Superior Energy Performance Certification Protocol," SEP Resour., 2012.

[21] CDP, "CDP Global Climate Change Report 2015,” 2015.

[22] RobecoSAM, "RobecoSAM 's Corporate Sustainability Assessment Companion," 2016.

[23] Corporate Knights, "Global 100 Key performance indicators," 2014. [Online]. Available: http://www.corporateknights.com/reports/2014-global-100/key-performance-indicators13903955/. [Accessed: 18-Sep-2016].

[24] RobecoSAM, "The Sustainability Yearbook 2016," 2016.

[25] Newsweek, "2016 Newsweek Green Rankings: FAQ," 2016. [Online]. Available: http://europe.newsweek.com/

2016-newsweek-green-rankings-faq-464496?rm=eu.

[26] UNFCCC, "The Paris Agreement - United Nations Framework Convention on Climate Change," 2016. [Online]. Available: http://unfccc.int/paris_agreement/items/9485.php. [Accessed: 27-Oct-2016].

[27] World Business Council for Sustainable Development (WBCSD) and World Resources Institute (WRI), "A Corporate Accounting and Reporting Standard," Greenh. Gas Protoc., pp. 1-116, 2004. 
N. Finnerty, S. Contreras, R. Sterling, D. Coakley \& M. M. Keane: Defining Corporate Energy Policy and Strategy to Achieve Carbon Emissions Reduction in Non-Energy Intensive Multi-Site Industrial Organisations

[28] World Resources Institute and World Business Council for Sustainable Development, "The Green House Gas Protocol: A Corporate Accounting and Reporting Standard," 2004.

[29] G. T. Doran, "There's a S.M.A.R.T. way to write management's goals and objectives," Manage. Rev., vol. 70, no. 11, pp. 35-36, 1981.

[30] N. Finnerty, R. Sterling, D. Coakley, S. Contreras, R. Coffey, and M. M. Keane, "Development of a Global Energy Management System for non-energy intensive multi-site industrial organisations: A methodology," Energy, no. Forthcoming, 2016.

[31] Global Reporting Initiative (GRI), "Sustainability reporting guidelines," 2006.

[32] S. Contreras, "A multi-criteria decision method to prioritise energy improvement projects using sustainability criteria," National University of Ireland, Galway, 2016. 
$16 \quad 10^{\text {TH }}$ INTERNATIONAL CONFERENCE ON SUSTAINABLE ENERGY AND ENVIRONMENTAL

Protection (June $27^{\mathrm{TH}}-30^{\mathrm{TH}}, 2017$, Bled, Slovenia), ENERgy Management AND POLICIES 
$10^{\mathrm{TH}}$ InTERnational CONFERENCE ON Sustainable ENERgy AND

Environmental Protection (June 27 $7^{\mathrm{TH}}-30^{\mathrm{TH}}, 2017$, BLed,

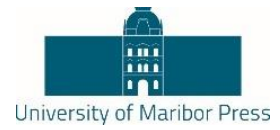

\title{
A Systematic Decision Support Framework and Prioritization Method for Energy Projects in Industrial Organisations
}

\author{
SERGio Contreras, NoEl FInNERTy, RAYMOND STERling, DANIEl COAKLEY \& \\ MARCUS M. KEANE
}

\begin{abstract}
This paper describes a decision support framework to help industrial organisations make positive investment decisions on energy performance improvement projects. It is intended as a simple and repeatable approach for energy managers to promote informed, unbiased energy-related decision-making from top management. The framework is underpinned by a project prioritisation tool that uses economic, environmental, social and technical criteria. This tool is a hybrid multicriteria decision method that combines Analytical Hierarchy Process, Fuzzy Logic and Technique for Order of Preference by Similarity to Ideal Solution. The proposed methodology is applied in a case study concerning five energy projects in a Fortune 500 manufacturing corporation in the life sciences industry. Results show the application of this decision support framework resulted in increased funding for energy projects within this large organisation.
\end{abstract}

Keywords: • Energy • energy management • project prioritisation • decision-making method • ISO-50001•

CORRESPONDENCE ADDRESS: Sergio Contreras, College of Engineering and Informatics, IRUSE, Ryan Institute, NUI, Galway, Ireland, email: sdcontrerasg@gmail.com. Noel Finnerty, Boston Scientific Corporation, Ballybrit Business Park, Galway, Ireland, email: Noel.Finnerty@ bsci.com, Raymond Sterling, PhD, Researcher, College of Engineering and Informatics, IRUSE, Ryan Institute, NUI, Galway, Ireland, email: raymond.sterling@nuigalway.ie. Daniel Coakley, PhD, College of Engineering and Informatics, IRUSE, Ryan Institute, NUI, Galway, Ireland, email: danielcoakley1@gmail.com. Marcus M. Keane, Lecturer, College of Engineering and Informatics, IRUSE, Ryan Institute, NUI, Galway, Ireland, email: Marcus.keane@ nuigalway.ie.

https://doi.org/10.18690/978-961-286-051-6.2

ISBN 978-961-286-051-6

(C) 2017 University of Maribor Press

Available at: http://press.um.si. 
$10^{\mathrm{TH}}$ INTERNATIONAL CONFERENCE ON SUSTAINABLE ENERGY AND ENVIRONMENTAL Protection (June $27^{\mathrm{TH}}-30^{\mathrm{TH}}, 2017$, Bled, SLOVENiA), ENERGy MANAGEMENT AND POLICIES

S. Contreras, N. Finnerty, R. Sterling, D. Coakley \& M. M. Keane: A Systematic Decision Support Framework and Prioritization Method for Energy Projects in Industrial Organisations

In implementing energy management, organisations align to standards such as ISO-50001 aimed at improving energy performance. These standards require implementing organisations to develop and prioritise energy performance improvement projects. However, specific guidelines for such prioritisation are missing, resulting in organisations having to create bespoke solutions. For industrial firms, including nonenergy intensive multi-site organisations ${ }^{1}$ with operations across a network of sites, this ad-hoc approach may result in both, under-investment and non-optimal or biased investment decisions. This has been highlighted in literature as a contributing factor to the energy efficiency gap [1].

This work proposes a project prioritisation tool to close this gap as part of a decision support framework. The proposed framework is aimed at ensuring top management are presented with all the necessary, un-biased characteristics and performance trends, from any site within an organisation, coupled with key performance indicators on the proposed energy performance improvement projects and their associated impact on the organisation.

The prioritisation tool is a hybrid multi-criteria decision method (MCDM) that combines different decision-making methodologies: Analytical Hierarchy Process (AHP), Fuzzy Logic (FL) and Technique for Order of Preference by Similarity to Ideal Solution (TOPSIS). In this MCDM, the novelty lies on how the organisation's priorities are translated into criteria weights (i.e. technical, environmental, financial and social) via qualitative assessment by top management.

\section{$2 \quad$ Literature Review}

\subsection{Decision making in companies}

Energy related projects are rarely seen as a priority in manufacturing firms [2], leading to lack of top management involvement, competition for funding with other investments considered as "more important", limited financial resources and unstructured decision making processes [3]. Understanding of the investment decision processes plays a definitive role in the execution of energy projects. Such processes are composed by a sequential and dynamic set of decision events which are not always linked to financial evaluations and depend on diverse context factors that vary from firm to firm. The approval or refusal of proposals is, therefore, influenced by investment categorisation, size, culture and complexity of the organisation [4] [5]. Furthermore, internal and external cultural factors also shape the decision-making processes [6].

Since "profitability plays an important but not decisive role in investment decisionmaking" [12], strategic alignment of energy projects requires not only attractive financial 
$10^{\mathrm{TH}}$ INTERNATIONAL CONFERENCE ON SUSTAINABLE ENERGY AND ENVIRONMENTAL Protection (June $27^{\mathrm{TH}}-30^{\mathrm{TH}}, 2017$, Bled, Slovenia), ENERgy MANAGEMENT AND

S. Contreras, N. Finnerty, R. Sterling, D. Coakley \& M. M. Keane: A Systematic Decision Support Framework and Prioritization Method for Energy Projects in Industrial Organisations

figures, but also awareness on the connection of energy investments with the organisation's core business activities. Such awareness presents top managers with compelling, informed business cases [3].

In organisations, energy-related decision-making process begins "once the need for an investment in energy efficiency is identified" [4]. It finishes either with a refusal decision for the investment proposals or with implementation of the measure designed to address the initial need. The evaluation and choice of solutions to address the identified need corresponds to the prioritisation of energy improvement investments required by ISO50001 [7]. Companies without a specific category for energy investments may create an unbalanced competition between them and other investments directly linked with the firm's core business. This may lead to negative decision-making outcomes for energy investments not considered strategic [3].

An approach to present top-management with business case supported by a structured, unbiased and informed decision-making framework is needed.

\subsection{Multi-criteria decision making for energy projects}

Multi-criteria decision methods (MCDM) are techniques that aim at facilitating a rational ranking of alternatives to select the best. MCDM are especially advantageous when using conflicting criteria, as for example, capital cost of energy generation technologies versus their contribution to reduce $\mathrm{CO}_{2}$ emissions in a manufacturing site.

Large industrial organisations are expected to support a continuous improvement of energy performance to advance the organisation's sustainability record. The energy management system should employ a holistic approach, aligned to sustainability criteria, to prioritise energy projects. MCDM developed in the field of sustainable energy provide a suitable reference.

The use of sustainability criteria and MCDM to rank energy projects was covered in detail by Wang [8]. Wang's work identified financial, environmental, social and technical criteria as the preferred set for ranking energy projects. These findings align with the standard triple bottom line (TBL) approach of sustainability assessments (economic, environment, society) [9] complementing it with the technical side of the energy project if needed. Table 1 contains a list of criteria that are frequently used in sustainable energy oriented MCDM. 
$10^{\mathrm{TH}}$ INTERNATIONAL CONFERENCE ON SUSTAINABLE ENERGY AND ENVIRONMENTAL Protection (June $27^{\mathrm{TH}}-30^{\mathrm{TH}}, 2017$, Bled, SLOVENiA), ENERGy MANAGEMENT AND POLICIES

S. Contreras, N. Finnerty, R. Sterling, D. Coakley \& M. M. Keane: A Systematic Decision Support Framework and Prioritization Method for Energy Projects in Industrial Organisations

Table 1. List of evaluation criteria

\begin{tabular}{|c|c|}
\hline Criteria & Sub-Criteria \\
\hline \multirow{8}{*}{ Economical } & Investment cost - CAPEX \\
\hline & Payback period (Simply / discounted) \\
\hline & Annual O\&M cost - OPEX \\
\hline & Equivalent annual cost \\
\hline & Net present value-NPV \\
\hline & Internal rate of return - IRR \\
\hline & Fuel Cost or Electricity cost \\
\hline & Fuel availability, Service life \\
\hline \multirow{6}{*}{ Environment } & NOx emissions, $\mathrm{CO}$ emissions \\
\hline & $\mathrm{CO}_{2}$ emissions, $\mathrm{SO}_{2}$ emissions \\
\hline & Particles emissions \\
\hline & Renewable energy fraction \\
\hline & Volatile hydrocarbons emissions \\
\hline & Land use, Noise \\
\hline \multirow{5}{*}{ Social } & Social (stakeholders) acceptability \\
\hline & Job creation, Future suitability \\
\hline & Effect for energy security \\
\hline & Benefited communities/ persons \\
\hline & Safety, Safeguards \\
\hline \multirow{6}{*}{ Technical } & Efficiency, Exergy efficiency \\
\hline & Automation grade \\
\hline & Primary energy ratio \\
\hline & Operability, Reliability \\
\hline & Technology maturity \\
\hline & Technology innovation \\
\hline
\end{tabular}

With regard to the techniques used in energy and sustainability decision-making, Analytical Hierarchy Process (AHP) is the preferred method [10]. AHP is based on disaggregation of a problem into several levels to construct a hierarchy that eases problem solving (see Figure 4). When applied to sustainability problems, an AHP model with two levels fits the TBL approach. The first level includes the environmental, economic and social criteria. The second level sub-criteria are those included in Table 1.

By combining AHP with other techniques such as TOPSIS and FL, the resulting hybridMCDM are appropriate for use in complex multi-criteria assessments involving qualitative criteria, human judgments and uncertainty [11], [12].

TOPSIS is a decision-making technique broadly used due to its simplicity and easy programmable computation process [11]. It is based on the concept that the best alternative shall be the closest to a positive ideal solution, and the farthest to a negative 
S. Contreras, N. Finnerty, R. Sterling, D. Coakley \& M. M. Keane: A Systematic Decision Support Framework and Prioritization Method for Energy Projects in Industrial Organisations

ideal solution [8], [13].

Fuzzy Logic is a theory that supports MCDM in dealing with human uncertainty of decision-makers. This theory facilitates MCDM to use qualitative criteria, for which performance is to be given in linguistic terms rather than numbers (i.e. low or high performance). It also facilitates the estimation of criteria weights, especially when combined with AHP [11]. FL translates linguistic evaluations into numerical figures [14].

\section{$3 \quad$ Methodology}

\subsection{Decision Support Framework}

An organisation's energy strategy should define the targets, roadmap and enablers required to meet the long-term objectives committed to by an energy policy. Meeting the targets requires investment. To ensure optimal investment a 'Decision Support Framework' (DSF) is needed to allow top management unbiased visibility to all potential Energy Efficiency Measures (EEM) from any site [15].

A minimal DSF dataset requires information from both site and corporate level. Site level data (top-row Figure 3) is tactical in nature and includes the proposed energy performance measure parameters (i.e. 1MW solar) and site energy performance metrics (i.e. energy consumption performance history and energy management maturity assessment). The corporate level data (bottom-row Figure 3) is strategic in nature and includes the preferred financial funding mechanism (i.e. own capital vs. Power Purchase Agreements -PPA) and the critical output from a project prioritisation tool.

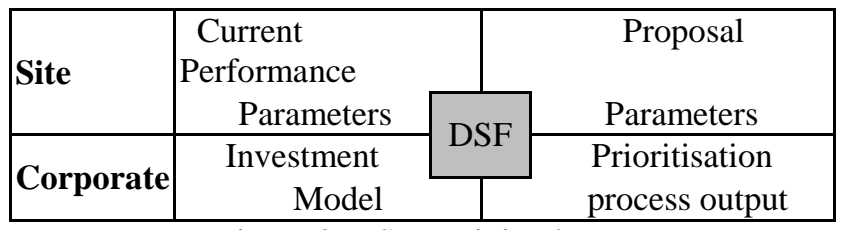

Figure 3. DSF - Minimal Dataset

The DSF presents a robust overview of all proposed energy projects and their respective impact at a site and organisation levels. Through this presentation of energy opportunities to the executive leadership, informed decision-making may take place promoting increased funding for energy efficient projects across the organisation.

The prioritisation process, as described in next section, is supported by a multi-criteria decision making method (MCDM). 
S. Contreras, N. Finnerty, R. Sterling, D. Coakley \& M. M. Keane: A Systematic Decision Support Framework and Prioritization Method for Energy Projects in Industrial Organisations

\subsection{Multi-criteria decision methods}

The proposed MCDM is a hybrid approach that combines Fuzzy Logic, AHP and TOPSIS. It is based on previous MCDM [11], [12] and has the following general characteristics:

- An AHP structure with two levels. Economic, environmental, social and technical criteria on the $1^{\text {st }}$ level. 14 sub-criteria on the $2^{\text {nd }}$ level.

- Economic and environmental criteria composed by quantitative sub-criteria.

- Social and technical criteria composed by qualitative sub-criteria.

- A criteria weighing method based on AHP linguistic pair-wise comparisons, FL and extent analysis [16].

- TOPSIS and FL to establish the best solution.

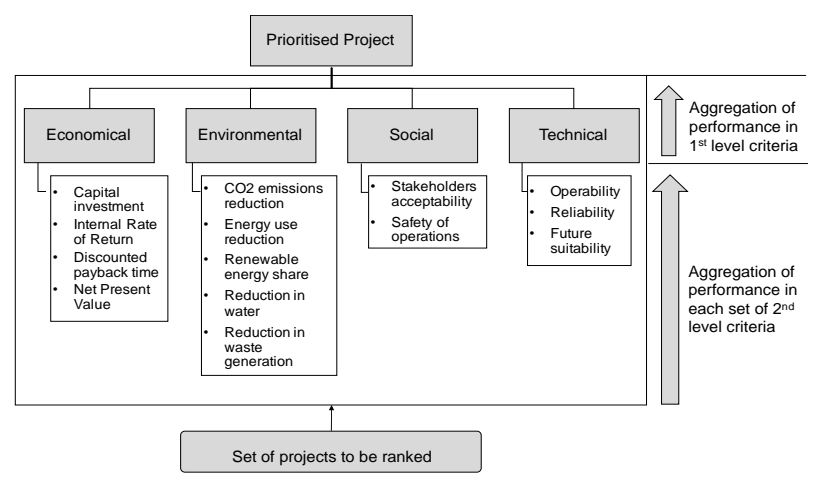

Figure 4. AHP structure and sets of criteria

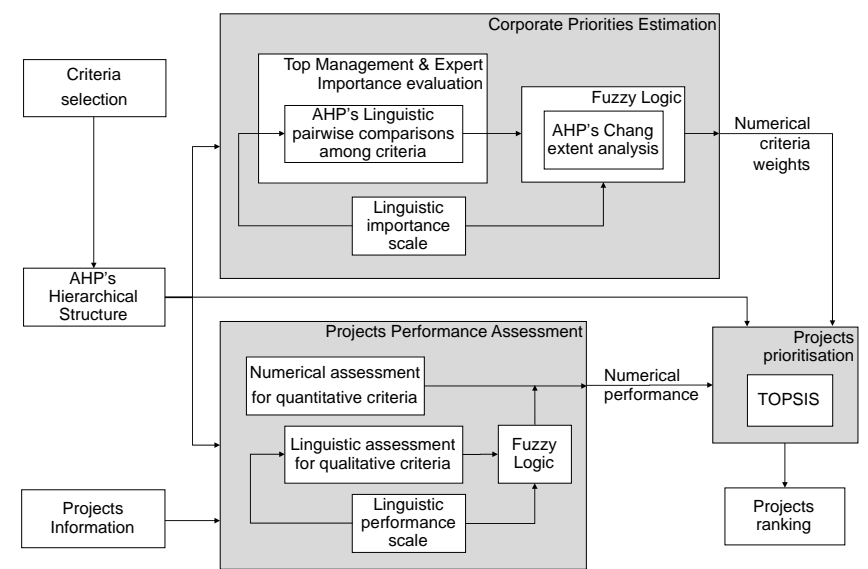

Figure 5. MCDM flowchart 
S. Contreras, N. Finnerty, R. Sterling, D. Coakley \& M. M. Keane: A Systematic Decision Support Framework and Prioritization Method for Energy Projects in Industrial Organisations

The flowchart presented in Figure 5 describes how the MCDM produces a ranking of energy projects. Qualitative performance assessments are based on subjective opinions about characteristics of energy projects and the technologies involved. Evaluators are provided with the following linguistic performance scale: very low, low, medium, high, very high. The evaluations are then translated into numerical assessments using FL for triangular fuzzy sets (TFN), see Figure 6.

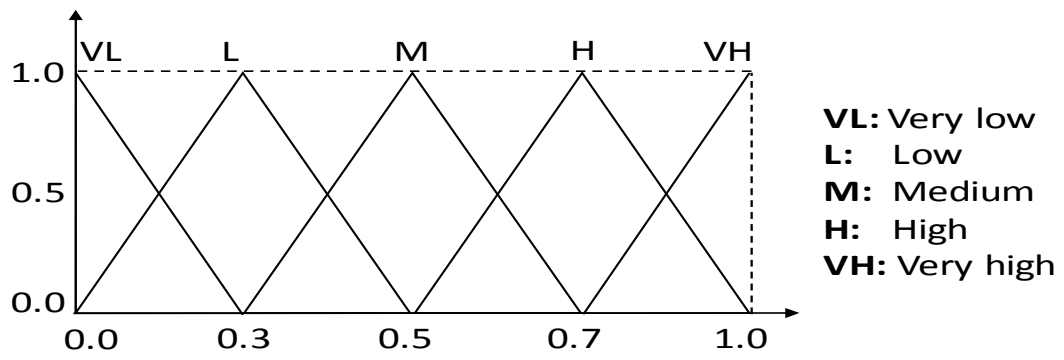

Figure 6. Linguistic performance scale and associated TFN sets [11], [12]

Criteria weights estimation is carried out by AHP pairwise comparisons. This step requires to elucidate the n's priorities when appraising energy projects. As indicated in Figure 5, opinions from the organisation's top managers and experts are used to understand those priorities and translate them into criteria weights. Nonetheless, inherent vagueness is expected in this process. To deal with that uncertainty, the novel MCDM proposed in this research work, requires managers and experts to complete two tasks. First, to judge whether criteria X (i.e. environmental) is more important than criteria $\mathrm{Y}$ (i.e. economical) within their organisation. And second, to use a linguistic importance scale to grade the relative importance of the more important criteria over the another (i.e. strongly more important). The linguistic importance scale is provided in Figure 7.

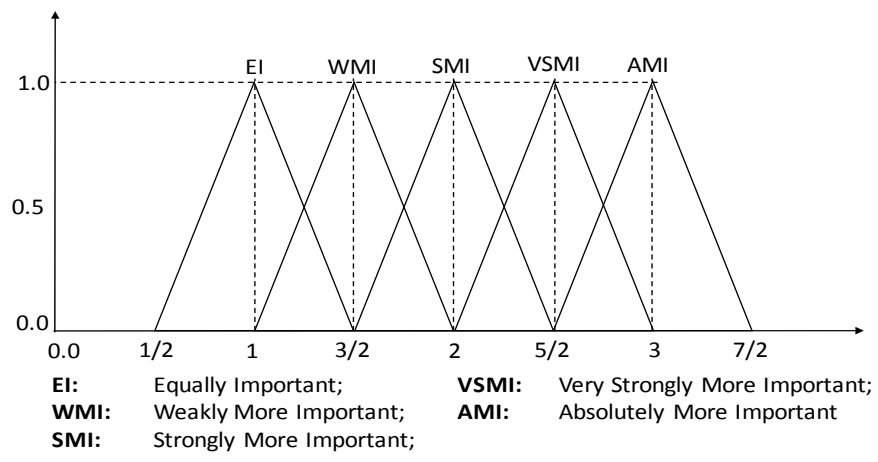

Figure 7. Linguistic importance scale and associated TFN sets [14]. 

POLICIES

S. Contreras, N. Finnerty, R. Sterling, D. Coakley \& M. M. Keane: A Systematic Decision Support Framework and Prioritization Method for Energy Projects in Industrial Organisations

Estimation of the numerical criteria weights is carried out using Chang's Extent Analysis for fuzzy-AHP [5] and the TFN shown in Figure 7.

Final project prioritisation is carried out by the TOPSIS component of the MCDM. It employs the numerical performances of all projects and aggregates them in accordance with the AHP structure and criteria weights. TOPSIS ranks the set of projects based on their geometric distances from the Positive Ideal Solution and the Negative Ideal Solution of the decision-making problem. The MCDM assigns a score of $100 \%$ to the top ranked project, because it is the closest project to the ideal solution. The rest of the projects are assigned proportional scores depending on their closeness to the best project. For instance, the score for the bottom ranked project is $0 \%$.

\section{$4 \quad$ Case Study}

As part of the development and deployment of a global energy management system [15], the DSF and associated MCDM described in Section 3 have been implemented to assist the investment decision for five energy projects in five different manufacturing sites in Boston Scientific Corporation (BSC). BSC is a non-energy intensive multi-national manufacturing corporation. For BSC, the DSF serves two mutually exclusive target audiences:

- Clear presentation of energy opportunities to the executive leadership;

- Normalized benchmark performance for the site energy manager.

\subsection{MCDM application}

Criteria weighing: The criteria weights were estimated using FL to transform the linguistic pairwise comparisons carried out by the appropriate top managers and experts in each discipline within the organisation. The estimated weights for first and second level criteria are reported in Table 2. 
S. Contreras, N. Finnerty, R. Sterling, D. Coakley \& M. M. Keane: A Systematic Decision Support Framework and Prioritization Method for Energy Projects in Industrial Organisations

Table 2. Criteria weights

\begin{tabular}{|l|c|l|c|}
\hline $\begin{array}{l}\text { Descript } \\
\text { ion }\end{array}$ & $\begin{array}{c}\text { Weight } \\
\mathbf{\%}\end{array}$ & Description & $\begin{array}{c}\text { Weight } \\
\mathbf{\%}\end{array}$ \\
\hline \multirow{4}{*}{$\begin{array}{l}\text { Economi } \\
\text { c }\end{array}$} & \multirow{2}{*}{31} & $\begin{array}{l}\text { Initial Capital } \\
\text { Investment }\end{array}$ & 18 \\
\cline { 3 - 3 } & & Net Present Value & 47 \\
\cline { 3 - 4 } & & Internal Return Ratio & 18 \\
\cline { 3 - 4 } & $\begin{array}{l}\text { Discounted Payback } \\
\text { Time }\end{array}$ & 18 \\
\hline \multirow{5}{*}{$\begin{array}{l}\text { Environ } \\
\text { mental }\end{array}$} & \multirow{2}{*}{34} & $\begin{array}{l}\text { CO2 Emissions } \\
\text { Reduction }\end{array}$ & 29 \\
\cline { 3 - 4 } & $\begin{array}{l}\text { Energy Consumption } \\
\text { Reduction }\end{array}$ & 29 \\
\cline { 3 - 4 } & $\begin{array}{l}\text { Renewable Energy } \\
\text { Share }\end{array}$ & 26 \\
\cline { 3 - 4 } & $\begin{array}{l}\text { Water Consumption } \\
\text { Reduction }\end{array}$ & 1 \\
\cline { 3 - 4 } & $\begin{array}{l}\text { Waste Generation } \\
\text { Reduction }\end{array}$ & 14 \\
\hline \multirow{3}{*}{ Social } & 9 & Safety of Operation & 68 \\
\cline { 3 - 4 } & $\begin{array}{l}\text { Stakeholder's } \\
\text { Acceptability }\end{array}$ & 32 \\
\hline \multirow{2}{*}{$\begin{array}{l}\text { Technic } \\
\text { al }\end{array}$} & \multirow{2}{*}{26} & Operability & 34 \\
\cline { 3 - 4 } & Reliability & Future Suitability & 10 \\
\cline { 3 - 4 } & & & \\
\hline
\end{tabular}

Table 2 indicates that environmental performance is the priority when ranking energy projects at BSC. The economic criteria are the second priority, followed closely by the technical criteria.

Projects: The MCDM was applied to prioritise five energy investment opportunities BSC. The set of projects comprises a Tri-generation System (P1) for Site 1; a new Combined Heat \& Power plant (P2) for Site 2; an Ice Storage System (P3) for Site 3; a Chillers' Upgrade project (P4) for Site 4; and a Solar PV System (P5) for Site 5.

The evaluation matrix: Information for the five projects per the criteria listed in Table 2 is presented in the evaluation matrix Table 3. Performances for quantitative and qualitative criteria are numerically and linguistically expressed respectively.

Project prioritisation: The prioritisation outcome is shown in Table 4. It depicts the project ' $\mathrm{P} 5$ ' as the top ranked, followed by project ' $\mathrm{P} 2$ ', which offers only half the rating than 'P5'. The output of the MCDM provides an unbiased ranking for the available 
$10^{\mathrm{TH}}$ INTERNATIONAL CONFERENCE ON SUSTAINABLE ENERGY AND ENVIRONMENTAL Protection (June 27 $7^{\mathrm{TH}}-30^{\mathrm{TH}}, 2017$, Bled, Slovenia), EnERgy Management AND Policies

S. Contreras, N. Finnerty, R. Sterling, D. Coakley \& M. M. Keane: A Systematic Decision Support Framework and Prioritization Method for Energy Projects in Industrial Organisations

investment opportunities based on the priorities of the organisation as defined by the criteria weighting. This score is the input into the DSF (Figure 1).

Table 3. Decision-making matrix

\begin{tabular}{|c|c|c|c|c|c|c|c|}
\hline \multirow{2}{*}{\begin{tabular}{|l|} 
First \\
Level \\
Criteria \\
\end{tabular}} & \multicolumn{2}{|r|}{ Second Level Criteria } & \multirow{2}{*}{$\begin{array}{c}\text { P1 } \\
\text { Site } 1\end{array}$} & \multirow{2}{*}{\begin{tabular}{|c|} 
P2 \\
Site 2 \\
\end{tabular}} & \multirow{2}{*}{\begin{tabular}{|c|} 
P3 \\
Site 3
\end{tabular}} & \multirow{2}{*}{$\begin{array}{c}\text { P4 } \\
\text { Site } 4\end{array}$} & \multirow{2}{*}{$\begin{array}{c}\text { P5 } \\
\text { Site } 5\end{array}$} \\
\hline & $\begin{array}{l}\text { Attri } \\
\text { bute }\end{array}$ & Description & & & & & \\
\hline \multirow{4}{*}{ Economic } & Cost & $\begin{array}{l}\text { Initial } \\
\text { Investment (\$) }\end{array}$ & $\begin{array}{c}\$ 2,575,0 \\
00\end{array}$ & $\begin{array}{l}\$ 1,34 \\
6,000 \\
\end{array}$ & $\begin{array}{c}\$ 1,250 \\
000\end{array}$ & $\$ 800,000$ & $\$ 0$ \\
\hline & $\begin{array}{l}\text { Bene } \\
\text { fit }\end{array}$ & Net Present Value (S) & $\$ 841,000$ & $\begin{array}{l}\$ 1,90 \\
0,000\end{array}$ & \begin{tabular}{|c|}
$\$ 609,62$ \\
7 \\
\end{tabular} & $\$ 996,000$ & $\begin{array}{c}\$ 900,0 \\
00\end{array}$ \\
\hline & $\begin{array}{l}\text { Bene } \\
\text { fit }\end{array}$ & $\begin{array}{l}\text { Internal Return Ratio } \\
(\%)\end{array}$ & 19 & 45 & 23 & 40.0 & 100 \\
\hline & Cost & $\begin{array}{ll}\text { Discounted } & \text { Payback } \\
\text { Time (yr.) } & \end{array}$ & 3.9 & 2.1 & 3.6 & 2.7 & 0.0 \\
\hline \multirow{5}{*}{$\begin{array}{l}\text { Environ } \\
\text { mental }\end{array}$} & $\begin{array}{l}\text { Bene } \\
\text { fit }\end{array}$ & $\begin{array}{ll}\mathrm{CO}_{2} & \text { Emissions } \\
\text { Reduction }(\%)\end{array}$ & 1.9 & 1.5 & 0.0 & 0.5 & 0.6 \\
\hline & $\begin{array}{l}\text { Bene } \\
\text { fit }\end{array}$ & $\begin{array}{l}\text { Energy Consumption } \\
\text { Reduction }(\%)\end{array}$ & 1.9 & 1.3 & 0.6 & 0.4 & 0.2 \\
\hline & $\begin{array}{l}\text { Bene } \\
\text { fit }\end{array}$ & $\begin{array}{l}\text { Renewable Energy } \\
\text { Share Increment }(\%)\end{array}$ & 0.0 & 0.0 & 0.0 & 0.0 & 37.0 \\
\hline & $\begin{array}{l}\text { Bene } \\
\text { fit } \\
\end{array}$ & $\begin{array}{l}\text { Water Consumption } \\
\text { Reduction }(\%)\end{array}$ & 0.0 & 0.0 & 0.0 & 0.0 & 0.0 \\
\hline & $\begin{array}{l}\text { Bene } \\
\text { fit }\end{array}$ & $\begin{array}{l}\text { Waste Generation } \\
\text { Reduction }(\%)\end{array}$ & 0.0 & 0.0 & 0.0 & 0.0 & 0.0 \\
\hline \multirow{2}{*}{ Social } & $\begin{array}{l}\text { Bene } \\
\text { fit }\end{array}$ & Safety of Operation & High & High & High & High & $\begin{array}{l}\text { Very } \\
\text { High }\end{array}$ \\
\hline & $\begin{array}{l}\text { Bene } \\
\text { fit }\end{array}$ & $\begin{array}{l}\text { Stakeholder's } \\
\text { Acceptability }\end{array}$ & $\begin{array}{l}\text { Very } \\
\text { High }\end{array}$ & $\begin{array}{l}\text { Very } \\
\text { High } \\
\end{array}$ & \begin{tabular}{|c|}
$\begin{array}{c}\text { Mediu } \\
\mathrm{m}\end{array}$ \\
\end{tabular} & High & $\begin{array}{l}\text { Very } \\
\text { High }\end{array}$ \\
\hline \multirow{3}{*}{ Technical } & $\begin{array}{l}\text { Bene } \\
\text { fit }\end{array}$ & Operability & High & High & High & High & $\begin{array}{l}\text { Very } \\
\text { High }\end{array}$ \\
\hline & $\begin{array}{l}\text { Bene } \\
\text { fit } \\
\end{array}$ & Reliability & High & High & High & High & High \\
\hline & $\begin{array}{l}\text { Bene } \\
\text { fit }\end{array}$ & Future Suitability & Medium & $\begin{array}{c}\text { Mediu } \\
\text { m }\end{array}$ & $\begin{array}{l}\text { Very } \\
\text { High }\end{array}$ & Medium & $\begin{array}{l}\text { Very } \\
\text { High }\end{array}$ \\
\hline
\end{tabular}

\subsection{DSF results}

The DSF application results is shown in Table 4. 
S. Contreras, N. Finnerty, R. Sterling, D. Coakley \& M. M. Keane: A Systematic Decision Support Framework and Prioritization Method for Energy Projects in Industrial Organisations

The proposed DSF approach and its implementation at BSC resulted in four projects being funded in 2016. This is attributable, among other elements, to the improved decision-making process for energy projects enabled by the DSF.

Table 4. DSF dataset ${ }^{2}$

\begin{tabular}{|c|c|c|c|c|c|}
\hline \multirow[b]{2}{*}{$\frac{\tilde{U}}{\stackrel{\mathscr{E}}{o}}$} & \multirow{2}{*}{ 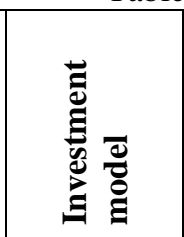 } & \multirow[b]{2}{*}{ 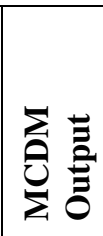 } & \multicolumn{2}{|c|}{$\begin{array}{c}\text { Current } \\
\text { Performance }\end{array}$} & \multirow{2}{*}{ 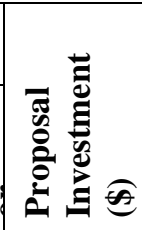 } \\
\hline & & & 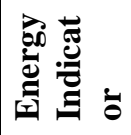 & 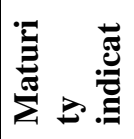 & \\
\hline P1 & Own capital & $\begin{array}{c}3 \\
(30 \%)\end{array}$ & 134 & 2.4 & $\begin{array}{r}\$ 2,575,0 \\
00 \\
\end{array}$ \\
\hline $\mathbf{P 2}$ & Own capital & $\begin{array}{c}2 \\
(50 \%)\end{array}$ & 128 & 2.2 & $\begin{array}{r}\$ 1,346,0 \\
00\end{array}$ \\
\hline P3 & Own capital & $\begin{array}{c}4 \\
(20 \%)\end{array}$ & 97 & 2.2 & $\begin{array}{r}\$ 1,250,0 \\
00\end{array}$ \\
\hline P4 & Own capital & $\begin{array}{c}5 \\
(0 \%) \\
\end{array}$ & 78 & 2.1 & $\$ 800,000$ \\
\hline P5 & PPA & $\begin{array}{c}1 \\
(100 \% \\
\end{array}$ & 78 & 2.1 & $\$ 0$ \\
\hline
\end{tabular}

\section{5}

\section{Conclusions}

The aim of the DSF is to present top management with an easy to understand yet comprehensive data-set of necessary, unbiased, information from proposed energy conservation measures to aid in the decision-making process. From the global energy manager perspective, the DSF is a condensed, repeatable, and effective template to request approval for funding, while for the executive leadership, it constitutes an understandable, fact based approach to reach informed decisions enabling optimal investment across the organisation.

The role of the DSF is not to eradicate the need for expert knowledge in project selection. It is important to note that the MCDM score does not necessary determine the order for funding. For example, the decision may conclude that the strategic need to improve the performance of one site out-weights the importance placed on the MCDM output for each individual project. In fact, the driver for capital investment may be to bring all sites to an acceptable level of performance and subsequently generate a list of projects to be implemented. This enables energy to become an asset that is maintained and invested in to ensure optimum running costs across the network. With a site only approach this is non-existent. 

POLICIES

S. Contreras, N. Finnerty, R. Sterling, D. Coakley \& M. M. Keane: A Systematic Decision Support Framework and Prioritization Method for Energy Projects in Industrial Organisations

The outputs of the MCDM are twofold. On the one hand, it elucidates the relative priorities given by the organisation to the environmental, economic, social and technical dimensions of energy improvement projects. On the other hand, it provides an objective prioritisation guide for resource allocation. Regarding the corporation's priorities, as per results shown in Table 2, this reveals that a project's contribution to improve the environmental footprint and business continuity have higher priority than financial benefits within this organisation. This outcome is aligned with results from empirical works on investment decisions for energy efficiency projects.

\section{Acknowledgements}

This publication has emanated from research supported in part by a research grant from Science Foundation Ireland (SFI) under Grant Number SFI/12/RC/2289 through a TP agreement between the SFI Centre for Ireland's Big Data and Analytics Research, ZuTec Inc. Ltd and Boston Scientific Corporation.

\section{Notes}

1 As suggested by previous literature, a company can be considered as non-energy intensive if its energy costs are less than $2 \%$ of its turnover or are less than $5 \%$ of its production costs [6], [17].

2 The energy and maturity indicators are outside the scope of this paper, the interested reader is referred to [15].

\section{References}

[1] P. Thollander and M. Ottosson, "Energy management practices in Swedish energyintensive industries," J. Clean. Prod., vol. 18, no. 12, pp. 1125-1133, Aug. 2010.

[2] E. Cagno and A. Trianni, "Evaluating the barriers to specific industrial energy efficiency measures: an exploratory study in small and medium-sized enterprises," J. Clean. Prod., vol. 82, pp. 70-83, Nov. 2014.

[3] C. Cooremans, "Make it strategic! Financial investment logic is not enough," Energy Effic., vol. 4, no. 4, pp. 473-492, 2011.

[4] T. Nehler and J. Rasmussen, "How do firms consider non-energy benefits? Empirical findings on energy-efficiency investments in Swedish industry," J. Clean. Prod., vol. 113, pp. 472-482, Feb. 2016.

[5] C. Cooremans, "Investment in energy efficiency: do the characteristics of investments matter?," Energy Effic., vol. 5, no. 4, pp. 497-518, Nov. 2012.

[6] A. Trianni, E. Cagno, and S. Farné, "Barriers, drivers and decision-making process for industrial energy efficiency: A broad study among manufacturing small and medium-sized enterprises," Appl. Energy, vol.162, pp.1537-1551, Jan.2016.

[7] ISO, "ISO 50001:2011 - Energy management systems - Requirements with guidance for use." p. 16, 2011.

[8] J.-J. Wang, Y.-Y. Jing, C.-F. Zhang, and J.-H. Zhao, "Review on multi-criteria decision analysis aid in sustainable energy decision-making," Renew. Sustain. Energy Rev., vol. 13, no. 9 , pp. 2263-2278, 2009. 
S. Contreras, N. Finnerty, R. Sterling, D. Coakley \& M. M. Keane: A Systematic Decision Support Framework and Prioritization Method for Energy Projects in Industrial Organisations

[9] J. Pope, D. Annandale, and A. Morrison-saunders, "Conceptualising sustainability assessment," Environ. Impact Assess. Rev., vol. 24, pp. 595-616, 2004.

[10] V. Ibáñez-Forés, M. D. Bovea, and V. Pérez-Belis, "A holistic review of applied methodologies for assessing and selecting the optimal technological alternative from a sustainability perspective," J. Clean. Prod., vol. 70, pp. 259-281, 2014.

[11] T. Kaya and C. Kahraman, "Expert Systems with Applications Multicriteria decision making in energy planning using a modified fuzzy TOPSIS methodology," Expert Syst. Appl., vol. 38, no. 6, pp. 6577-6585, 2011.

[12] J.-J. Wang, Y.-Y. Jing, C.-F. Zhang, G.-H. Shi, and X.-T. Zhang, “A fuzzy multi-criteria decision-making model for trigeneration system," Energy Policy, vol. 36, no. 10, pp. 38233832, 2008.

[13] F. Cavallaro, "Fuzzy TOPSIS approach for assessing thermal-energy storage in concentrated solar power ( CSP ) systems," Appl. Energy, vol. 87, no. 2, pp. 496-503, 2010.

[14] C. Kahraman, T. Ertay, and G. Büyüközkan, "A fuzzy optimization model for QFD planning process using analytic network approach," Eur. J. Oper. Res., vol. 171, no. 2, pp. 390-411, 2006.

[15] N. Finnerty, R. Sterling, D. Coakley, S. Contreras, R. Coffey, and M. M. Keane, "Development of a Global Energy Management System for non-energy intensive multi-site industrial organisations: A methodology," Energy, no. Forthcoming, 2016.

[16] D.-Y. Chang, "Applications of the extent analysis method on fuzzy AHP," Eur. J. Oper. Res., vol. 95, no.3, pp.649-655, 1996.

[17] P. Rohdin and P. Thollander, "Barriers to and driving forces for energy efficiency in the non-energy intensive manufacturing industry in Sweden," Energy, vol. 31, no. 12, pp. 1836-1844, Sep. 2006 
$30 \quad 10^{\text {TH }}$ INTERNATIONAL CONFERENCE ON SUSTAINABLE ENERGY AND ENVIRONMENTAL

Protection (June $27^{\mathrm{TH}}-30^{\mathrm{TH}}, 2017$, Bled, Slovenia), Energy Management And

POLICIES 
$10^{\mathrm{TH}}$ InTERnAtional CONFERENCE ON Sustainable ENERgy AND ENVIRONMENTAL Protection (June $27^{\mathrm{TH}}-30^{\mathrm{TH}}$, 2017, Bled, SLOVENIA), ENERGy MANAGEMENT AND Policies

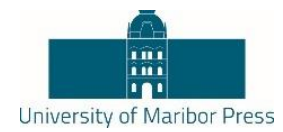

\title{
Energy Management System Standard Implementation at Yasar University in Izmir, Turkey: From Iso 50001 to Practice
}

\author{
HACER SEKERCI, NURDAN YILDIRIM \& ARIF HEPBASLI
}

\begin{abstract}
There are various approaches to energy management systems (EnMSs) in the literature. Among these, ISO 50001: 2011, which is the most recent Energy Management System Standard (EnMSS) and is also based on the Plan-Do-Check- Act (PDCA) continual improvement framework, has been widely used in many countries. Yasar University (YU) in Izmir, Turkey is the first and only university achieved TS EN ISO 50001:2011 Certification on 5 January 2016 in the country. In the present study, EnMSS will be briefly introduced first. How EnMS is implemented at YU according to ISO 50001 will be then explained. Finally, the lessons learned and best practices will be presented while main concluding remarks will be listed. The authors expect that the experience gained from establishing EnMS at YU will guide organizations in improving their energy management performance.
\end{abstract}

Keywords: • continual improvement • ISO $50001 \bullet$ energy management • energy management system • energy management system standard •

CORRESPONDENCE ADDRESS: Hacer Sekerci, Yasar University, Department of ElectricalElectronics Engineering, Faculty of Engineering, Kazımdirik Mahallesi, Üniversite Cd., 35100 Bornova/İzmir, Turkey; email: hacer.sekerci@yasar.edu.tr. Nurdan Yildirim, Yasar University, Department of Energy Systems Engineering, Faculty of Engineering, Kazımdirik Mahallesi, Üniversite Cd., 35100 Bornova/İzmir Turkey; emails: nurdan.yildirim@yasar.edu.tr. Arif Hepbasli, Yasar University, Department of Energy Systems Engineering, Faculty of Engineering, Kazımdirik Mahallesi, Üniversite Cd., 35100 Bornova/İzmir Turkey; emails: arif.hepbasli@yasar.edu.tr. 
$10^{\mathrm{TH}}$ INTERNATIONAL CONFERENCE ON SUSTAINABLE ENERGY AND ENVIRONMENTAL Protection (June $27^{\mathrm{TH}}-30^{\mathrm{TH}}, 2017$, Bled, Slovenia), Energy Management And POLICIES

H. Sekerci, N. Yildirim \& A. Hepbasli: Energy Management System Standard Implementation at Yasar University in Izmir, Turkey: From Iso 50001 to Practice

There are various management system standards, such as ISO 9001 (quality management), ISO 14001 (environmental management), ISO 22000 (food safety), and ISO/IEC 27001 (information security), which complement each other while an exery management system standard has been recently proposed by Hepbasli [1]. In particular, ISO 50001 (or BS EN 16001) follows the plan-do-check-act (PDCA) process for continual improvement of the energy management system [2]. These similar or common characteristics enable organizations to integrate exergy management with their overall efforts to improve quality, energy, environmental management and other challenges addressed by their management systems.

ISO 50001 is the international energy management system standard (EnMSS) issued in June 2011. The main objective of this standard is to focus on the continual improvement of energy performance, which covers the essential key items such as energy use, energy consumption, energy efficiency, and energy intensity.

A prescriptive step by step approach to implement an energy management system will help an organization perform the required tasks through effective resource allocation. The ISO 50001:2011 International Standard is a voluntary global management system standard and does specify mandatory requirements for an EnMS such as an energy policy, energy objectives, energy targets and action plans on significant energy uses [3], [4]. The ISO 50001 is a standalone standard and can be adopted regardless of any management systems (e.g. ISO 9001, 14001) that already exist. Depending on the size of any institution, it may be a separate standard or an integrated part of existing management system standards.

As far as some universities achieved the ISO 50001 standard are concerned, University College Cork (UCC) in Ireland has become the first third level institution worldwide to achieve the ISO 50001 standard in 2011, and is committed to continuous energy performance improvement to enhance the environment of the university community in which they work, teach and carry out research [5]. Singapore Management University (SMU) became the first public-funded, autonomous university in Singapore to achieve certification to the ISO 50001 EnMSS in 2013 [6]. Keele University, one of the first universities in the UK, achieved the ISO 50001 standard. The University's EnMS currently covers a combination of academic buildings, classrooms, lecture theatre, restaurant/cafe, teaching labs, kitchens and the estates activities for the academic and encompasses the work environments of approximately 1650 staff and 10000 students [7]. The University of Reading has become one of just a handful of universities in the UK to achieve certification to the ISO 50001 standard in 2015 [8]. Sheffield Hallam University also received the ISO certification and addresses a range of sustainability topics and issues such as energy management, engineering and environmental studies [9]. Turkish Standards Institution (abbreviated as TSE in Turkish) certified Yasar University's EnMS to TS EN ISO 50001:2011 (TS is the abbreviation of Turkish Standard) on 5 January 
H. Sekerci, N. Yildirim \& A. Hepbasli: Energy Management System Standard Implementation at Yasar University in Izmir, Turkey: From Iso 50001 to Practice

2016 [10]. One can conclude that up to date, the ISO 50001 standard has been applied mostly to industrial sector organizations and companies [4] while the number of universities achieved the ISO 50001 EnMSS is relatively very low.

The main objectives of this contribution are to (i) briefly present the EnMS structure of Yasar University, which was established in 2000 in Izmir, Turkey, (ii) explain some studies implemented within the framework of the ISO 50001 certification, and (iii) give some assessment values by focusing on the significant energy uses (SEUs), the energy baseline and energy performance indicators (EnPIs) in the planning part of the EnMSS.

\section{A Brief Outlook on Energy Management System Standard}

ISO 50001 is based on the PDCA continual improvement framework like ISO 9001 and ISO 14001. Figure 1 characterized by the authors shows the ISO 50001:2011 EnMS model based on the PDCA approach. As can be seen in the figure, this standard is depicted with four main steps as follows [3], [11]:

Plan: conducting the energy review and establishing the baseline, the EnPIs, objectives, targets and action plans necessary to deliver results in accordance with opportunities for improving the energy performance and the organization's energy policy.

Do: implementing the energy management action plans.

Check: monitoring and measuring processes and the key characteristics of its operations that determine energy performance against the energy policy and objectives and report the results.

Act: taking the necessary actions to continually improve energy performance and the EnMS. 
H. Sekerci, N. Yildirim \& A. Hepbasli: Energy Management System Standard Implementation at Yasar University in Izmir, Turkey: From Iso 50001 to Practice

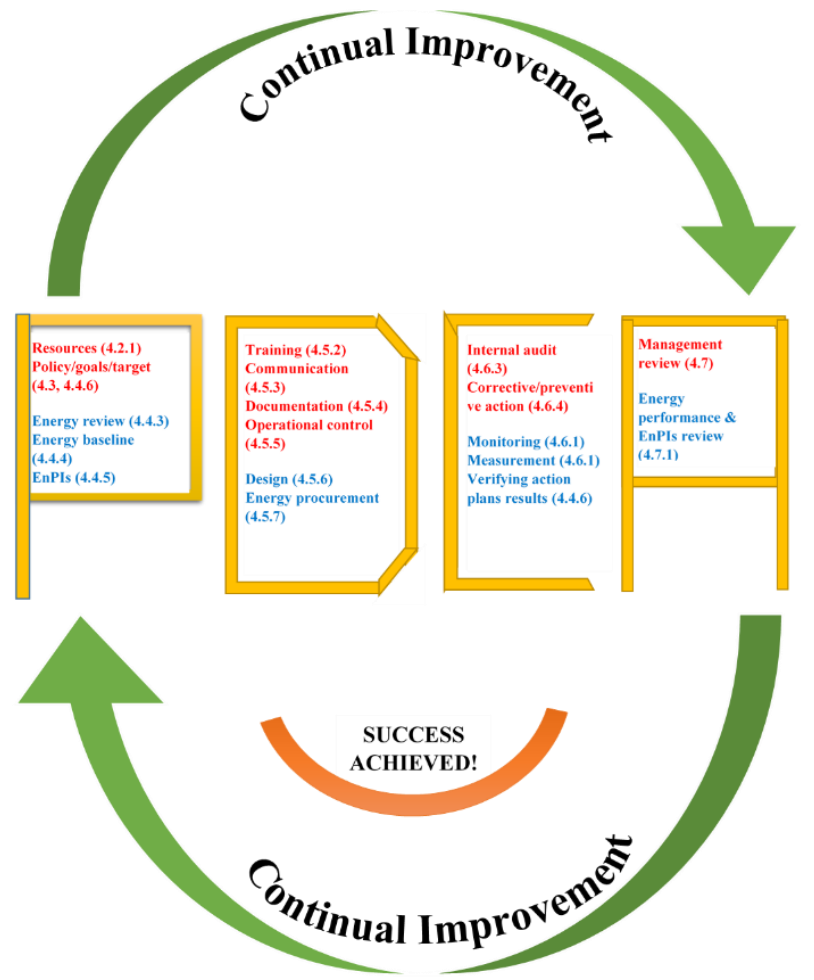

Figure 1. The ISO 50001:2011 EnMS Model

\section{An Application of Yasar University}

\subsection{Boundaries and scope}

EnMS covers the education and dormitory services belonging to Yasar University, located in Selcuk Yasar Campus and Yasar University Dormitory. Some enterprises (dining hall, cafeteria and copy center), which are located in Selcuk Yasar Campus and renders of Yasar University, are out of scope. Transportation activities are also left out of scope.

\subsection{Composing an energy policy}

Yasar University's energy policy has been composed as follows [12]:

As Yasar University, we are committed to continuously improving our energy performance in all our activities with an awareness of carrying the responsibility for the energy management system. 
H. Sekerci, N. Yildirim \& A. Hepbasli: Energy Management System Standard Implementation at Yasar University in Izmir, Turkey: From Iso 50001 to Practice

In order to achieve the above-mentioned objective, we will make every effort to:

Reduce energy and water usage in all our activities;

Raise cultural awareness about energy efficiency in our university by continuously organizing trainings/seminars;

Continuously monitor and report our energy consumption targets by defining them;

Perform regular energy efficiency audits for defining energy efficiency improvement areas;

Follow up updated legal statutes related to energy and water usage, and meet their requirements;

Include energy performance improvements in the design stages of projects;

Purchase and effectively utilize energy-efficient products and services.

\subsection{Appointing the management representative}

Energy Efficiency and Management Coordination Committee (EnEMCC) was formed on 16 December 2016, as shown in Figure 2.

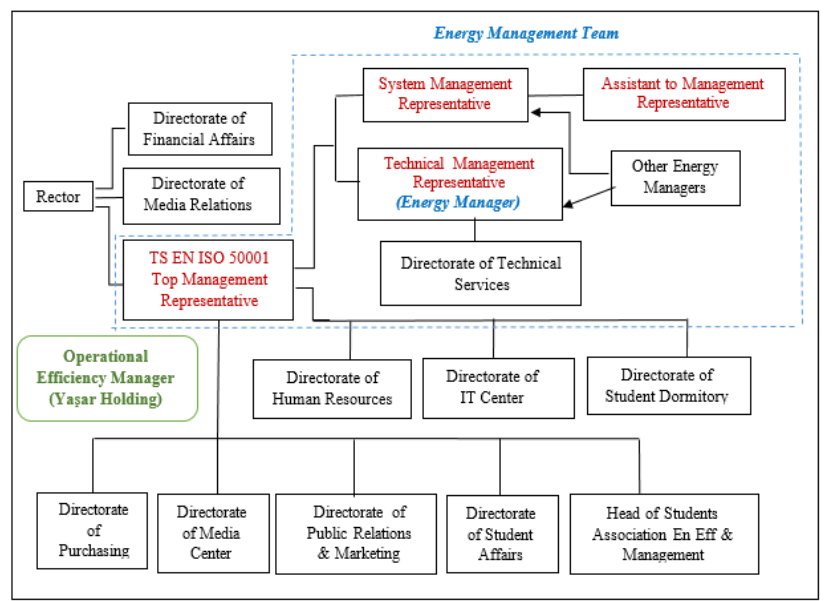

Figure 2. An Organizational Structure of the EnEMCC

In this regard, a top management representative, a technical management representative, a system management representative and an assistant to the system management representative were appointed. At Yasar University, there are 6 certified energy managers, of whom one acts the energy manager of the university. 
$10^{\mathrm{TH}}$ INTERNATIONAL CONFERENCE ON SUSTAINABLE ENERGY AND ENVIRONMENTAL Protection (June $27^{\mathrm{TH}}-30^{\mathrm{TH}}, 2017$, Bled, Slovenia), ENERgy Management AND POLICIES

H. Sekerci, N. Yildirim \& A. Hepbasli: Energy Management System Standard Implementation at Yasar University in Izmir, Turkey: From Iso 50001 to Practice

According to a regulation in Turkey, if yearly (annual) energy consumption exceeds the following cut off limits, an energy manager should be appointed or designated:

1000 tons of oil equivalent) TOE in industrial enterprises; 500 TOE or a construction are of $20000 \mathrm{~m}^{2}$ in buildings, and $250 \mathrm{TOE}$ in public enterprises. The annual TOE value for Yasar university is lower than this limit of $500 \mathrm{TOE}$ (being about $360 \mathrm{TOE}$-student hostel 17 TOE \& campus 343 TOE- in the year 2016), but the construction surface area is larger than this limit of $20000 \mathrm{~m}^{2}$ (campus $47547 \mathrm{~m}^{2} \&$ student hostel $9690 \mathrm{~m}^{2}$ ), at least one energy manager should be appointed. Figure 3 illustrates a picture of the energy management team, consisting of a total of 13 people from various disciplines such as mechanical, electrical-electronics, civil, of whom 6 are certified energy managers, 1 top management representative and the remainder from technical services department including the manager and technicians.

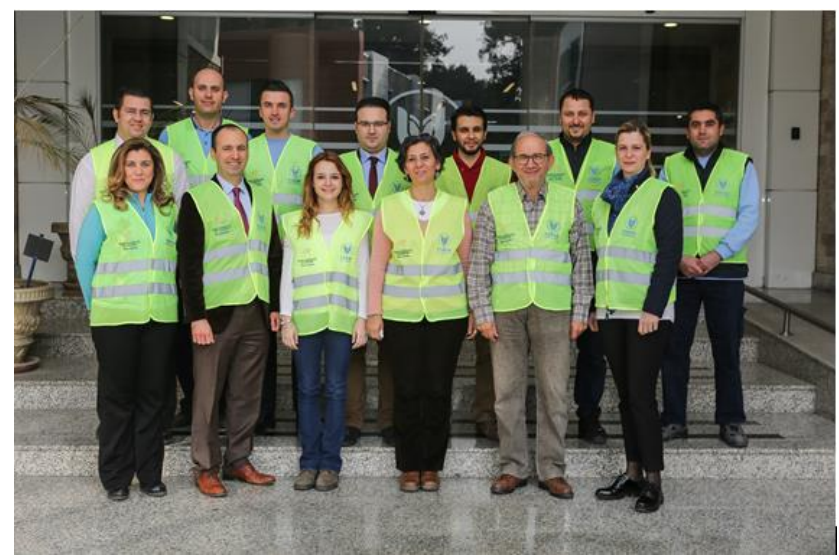

Figure 3. A Picture of the Energy Management Team

\subsection{Energy planning}

Energy planning consists of mainly three sections, namely planning inputs, energy review and planning outputs. Past and present energy uses along with relevant variables effecting the SEUs are inputs to the energy planning while energy baseline, EnPIs, energy objectives, energy targets and action plans fall into the outputs of the planning process. In this study, the SEUs, the baseline and EnPIs are considered as follows:

\subsubsection{Significant energy uses (SEUs)}

The criterion used for selecting energy uses as significant depends on the method applied. In this context, there are various approaches (e.g., energy balance, ranking, Pareto, fishbone diagram or identifying energy opportunities) to determining the SEUs in any enterprises. In this study, we selected the energy balance method. The criterion we used 
H. Sekerci, N. Yildirim \& A. Hepbasli: Energy Management System Standard Implementation at Yasar University in Izmir, Turkey: From Iso 50001 to Practice

was a percentage of the total energy consumption and the top three ranked energy uses after lighting and miscellaneous electrical usage were selected to be SEUs, as indicated in Table 1 where chillers, the boiler and air handling units are SEUs.

Table 1. Energy Balance Results for SEUs.

\begin{tabular}{|c|c|c|c|c|c|c|c|}
\hline Description & Size & Unit & Op. Hour & Load & kWh & MJ & \% Total \\
\hline \multicolumn{8}{|l|}{ Electrical Usage } \\
\hline Air handling units & 64.6 & $\mathrm{~kW}$ & 8640 & 0.9 & 502,330 & $1,808,387$ & $14.8 \%$ \\
\hline Cooling tower & 7.5 & $\mathrm{~kW}$ & 4320 & 0.8 & 25,920 & 93,312 & $0.8 \%$ \\
\hline Chiller & 216 & $\mathrm{~kW}$ & 4320 & 0.8 & 746,496 & $2,687,386$ & $21.9 \%$ \\
\hline Circulation pumps & 57.35 & kW & 8640 & 0.6 & 297,302 & $1,070,289$ & $8.7 \%$ \\
\hline Fire pumps & 150 & $\mathrm{~kW}$ & 100 & 0.5 & 7,500 & 27,000 & $0.2 \%$ \\
\hline $\begin{array}{l}\text { Sport center electrical } \\
\text { boiler }\end{array}$ & 35 & kW & 4320 & 0.5 & 75,600 & 272,160 & $2.2 \%$ \\
\hline $\begin{array}{l}\text { Lighting and misc. } \\
\text { electrical usage }\end{array}$ & & & & & & $5,108,896$ & $41.7 \%$ \\
\hline \multicolumn{8}{|l|}{ Natural Gas Usage } \\
\hline \multirow[t]{2}{*}{ Boiler } & 500 & $\mathrm{~kW}$ & 727 & 0.9 & 327,000 & $1,177,200$ & $9.6 \%$ \\
\hline & & & & & & $12,244,628$ & $100.0 \%$ \\
\hline
\end{tabular}

Enterprise Annual Energy Usage
\begin{tabular}{|l|c|c|}
\hline Source & Usage & Units \\
\hline Natural gas & $1,177,200$ & MJ \\
\hline Electricity & $11,067,428$ & MJ \\
\hline Combined MJ & $12,244,628$ & MJ \\
\hline
\end{tabular}

\subsubsection{Energy baseline}

The purpose of the energy baseline is to develop a starting point for measuring energy performance improvements [14]. In the literature there are different ways. In some cases, this can be a very complex subject, but the process can be simplified through the selection of the appropriate method.

In this regard, we used the driving factors, which have been established earlier to predict the amount of energy that should have been used and to compare it with what has actually been achieved, as recommended in Ref. [13]. The monthly heating and cooling degreedays are calculated by using measured hourly outside air temperatures in Yaşar University for the year of 2015 and 2016 . The design indoor temperature is taken as $22^{\circ} \mathrm{C}$ for winter and $26^{\circ} \mathrm{C}$ for summer to calculate degree-days. The baseline was established to be the best fit straight line on the regression chart of driver against energy use, as indicated in Figure 4. As performance improves, this line will move downwards. As it can be seen from Figure 4, the best fit straight line is $y=0.7869 x+249.67$ for 2015 and $y=0.771 x+244.79$ for 2016 . These show that the weather-dependent consumption per degree-day is $786.9 \mathrm{kWh}$ and $771 \mathrm{kWh}$ for the year of 2015 and 2016, respectively. 

Protection (June $27^{\mathrm{TH}}-30^{\mathrm{TH}}, 2017$, Bled, Slovenia), ENERgy Management AND POLICIES

H. Sekerci, N. Yildirim \& A. Hepbasli: Energy Management System Standard Implementation at Yasar University in Izmir, Turkey: From Iso 50001 to Practice

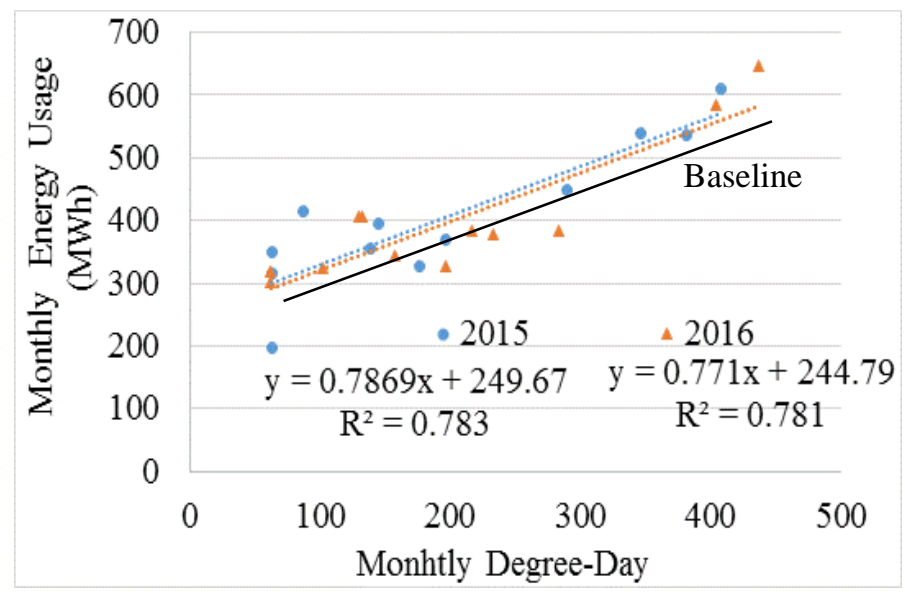

Figure 4. Establishing the Baseline

\subsubsection{Energy performance indicators}

The purpose of this activity is to identify a small number of indicators of energy performance which will help any enterprises to be confident that performance targets are being met and if not to alert any enterprises of any problems at an early stage [13].

There are also some factors, such as weather (e.g., temperature, dew point, relative humidity, and wind speed), operations (operating hours, operating days, operating shifts, seasonal variations, which affect EnPIs. In developing the EnPIs, relevant factors should be considered, as also stated in Ref. [14].

Various EnPIs used for assessing the performance of buildings are reviewed in Ref. [15]. The most commonly used energy benchmark is the simplified Energy Use intensity or Index (EUI) in $\mathrm{kWh} / \mathrm{m}^{2}$, which accounts for only one building feature that affects energy consumption.In this study, we used three different EnPIs. The first two ones are related to the EUI, as indicated in Figures 5 and 6. 
H. Sekerci, N. Yildirim \& A. Hepbasli: Energy Management System Standard Implementation at Yasar University in Izmir, Turkey: From Iso 50001 to Practice

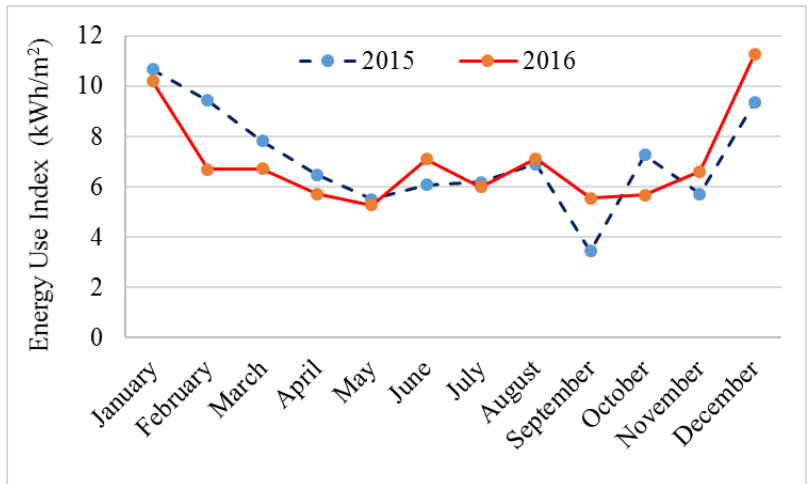

Figure 5. Energy Use Index per $\mathrm{m}^{2}$

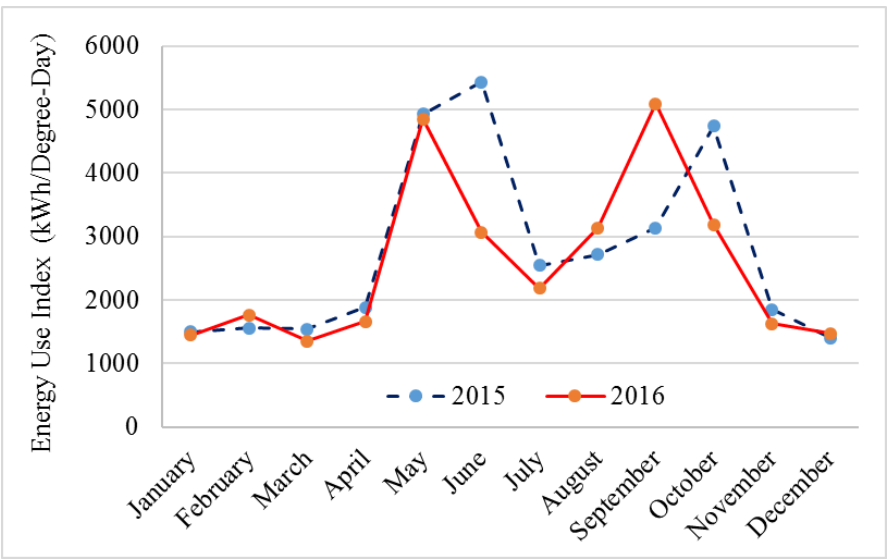

Figure 6. Energy Use Index per Degree-Day

The monthly EUI is in the range of 3.4-11.3 $\mathrm{kWh}$ per $\mathrm{m}^{2}$, while the range of EUI per degree-day is 1353.4-5092.6 kWh.

The third is the normalised performance indicator (EnNPI), defined as the annual consumption per $\mathrm{m}^{2}$ of floor area, normalised for weather, exposure, and hours of use. The annual electrical energy and natural gas usage in 2016 is $3921030.5 \mathrm{kWh}$ and 91840 $\mathrm{m}^{3}$, respectively. The EnNPI for the year of 2016 is calculated as $85.2 \mathrm{kWh} / \mathrm{m}^{2}$ with total $57237 \mathrm{~m}^{2}$ building area and $4874084.5 \mathrm{kWh}$ energy usage, while it is calculated as 87.5 $\mathrm{kWh} / \mathrm{m}^{2}$ for 2015 .

\subsection{Some awareness activities}

The following activities have been made during implementing the EnMS studies to increase energy awareness among staff and greater participation: 
- Awareness training for staff (from top management to the employees and students) on the importance of energy management and energy cost reduction has been included.

- Energy suggestion boxes (cubes) have been established to encourage the campus community to voice suggestions and concerns about energy usage and energy efficiency improvements [16].

- An orienteering event was organized. Students were given a specially prepared orienteering map, which they used to find control points, where energy efficiency-related questions were included.

- Students Association of Energy Efficiency and Management has been formed to motivate and encourage students to be aware of Yasar University's commitment to improved energy performance.

- Two courses, namely energy management and efficiency (mandatory for energy systems engineering students and elective for electrical-electronics engineering students), and EnMSSs (elective for all engineering students) have been offered to engineering students. The course EnMSSs has been delivered at Yasar University for the first time in the country.

\section{$4 \quad$ Concluding remarks}

One of the ways of maintaining sustainable development is to use energy efficiently. In this regard, establishing energy management systems in all institutions play an essential role because EnMS could offer many advantages, such as reductions in energy consumptions, energy costs and environmental impacts, improvement of corporate image.

We may list some main conclusions as follows:

a) University College Cork (UCC) in Ireland is World's First University to get ISO 50001 in 2011 while Yasar University achieved TS EN ISO 50001:2011 Certification for the first time in Turkey.

b) The majority of the enterprises achieved the ISO 50001:2011 certification come from industrial sectors while the number of universities received ISO 50001:2011 certificate is relatively very low.

c) Yasar University got the certificate in a period of 15 months without having any other management system standards, indicating the success of the university. The certificate is valid for 3 years, requiring an audit of the Turkish Standards Institution every year. In this regard, the first audit in December 2016 was successfully reported.

d) Considering that all roads lead to Rome, since all management standards follow the PDCA process for continual improvement of the performance, ISO 50001 can easily be integrated with other existing management system standards depending on the size of the university. 
$10^{\mathrm{TH}}$ INTERNATIONAL CONFERENCE ON SUSTAINABLE ENERGY AND ENVIRONMENTAL 41 Protection (June $27^{\mathrm{TH}}-30^{\mathrm{TH}}, 2017$, Bled, SLovenia), EnERgy MANAGEMENT AND

POLICIES

H. Sekerci, N. Yildirim \& A. Hepbasli: Energy Management System Standard Implementation at Yasar University in Izmir, Turkey: From Iso 50001 to Practice

e) Some exergy-based preliminary studies proposed in Ref. [15] have also been implemented at Yasar University. In this regard, it is recommended that some exergetic indicators for buildings be used.

f) The total annual energy usage is $4855255.9 \mathrm{kWh}$ and $4805053.8 \mathrm{kWh}$ for the year 2015 and 2016, respectively.

g) The EUIs are determined as $84.8 \mathrm{kWh} / \mathrm{m}^{2}$ and $2055 \mathrm{kWh} /$ degree-day for 2015 and $83.9 \mathrm{kWh} / \mathrm{m}^{2}$ and $1985.7 \mathrm{kWh} /$ degree-day for 2016 with total $57237 \mathrm{~m}^{2}$ building area.

h) The annual degree-days (including heating and cooling) are calculated 2362.6 and 2418.3 for 2015 and 2016 with the design indoor temperature of $22^{\circ} \mathrm{C}$ for winter and $26^{\circ} \mathrm{C}$ for summer, respectively.

i) The EnNPIs are determined as $87.5 \mathrm{kWh} / \mathrm{m}^{2}$ for 2015 and $85.2 \mathrm{kWh} / \mathrm{m}^{2}$ for 2016.

\section{Acknowledgements}

The authors would like to thank Mr. Ali Galip Ayvat (Top Management Representative), Mr. Serkan Gurbuz (Manager of Technical Services) and Mr. Tugrul Unutmaz (Energy Manager of the University) from Yasar University for providing the necessary data and their continual support.

\section{References}

[1] A. Hepbasli, "Proposing an exergy management system (ExMS) standard for establishing exergetically green aviation," Int. J. Sustainable Aviation, Vol. 2(4), pp. 271-283, 2016.

[2] United Nations Industrial Development Organization (UNIDO), "Two day energy management training. Student manual, practical guide for implementing an energy management system", United Nations Industrial Development Organization (UNIDO), Vienna: UNIDO, 2011.

[3] ISO 50001:2011(E). International standard, energy management systems -requirements with guidance for use. International Organization for Standardization; 2011.

[4] B. Gopalakrishnan, K. Ramamoorthy, E. Crowe, S. Chaudhari, and H. Latif, “A structured approach for facilitating the implementation of ISO 50001 standard in the manufacturing sector", Sustainable Energy Technologies and Assessments, vol. 7, pp. 154-165, 2014

[5] University College Cork (UCC), "UCC is World's 1st to Achieve ISO 50001 Standard", https://www.ucc.ie/en/build/energy/iso50001/, Access date: 17 March 2017.

[6] Eco Business, "Singapore Management University Spearheads Drive for Energy Efficiency with ISO 50001", Published by DNV Business Assurance Pte Ltd., 22 April 2013.

[7] "Lucideon Certifies Keele University Energy Management System to ISO 50001", http://www.eauc.org.uk/cics_certifies_keele_universityrsquos_energy_ma, Access date: 17 March 2017.

[8] The University of Reading, "University Certifies for International ISO50001 Energy Management

Standard", https://www.reading.ac.uk/internal/staffportal/news/articles/spsn-628239.aspx, Access date: 17 March 2017.

[9] BSI, "Case Study, Sheffield Hallam University, ISO 50001 Energy Management", BSIUK-023-MS-0712-E-LB. 
H. Sekerci, N. Yildirim \& A. Hepbasli: Energy Management System Standard Implementation at Yasar University in Izmir, Turkey: From Iso 50001 to Practice

[10] Yasar University News, “The first university achieved TS EN ISO 50001 certification,"http://haber.yasar.edu.tr/basari/ts-en-iso-50001-belgeli-ilk-universite.html, Access date: 18 March 2017 (in Turkish).

[11] S. Bougain, D. Gerhard, C. Nigischer, S. Uğurlu, "Towards energy management in production planning software based on energy consumption as a planning resource", CIRP 26, Procedia, pp.139 - 144, 2015.

[12] Yasar University-Energy Efficiency and Management, "Energy policy of our university," http://evy.yasar.edu.tr/en/energy-policy/, Access date: 18 March 2017.

[13] United Nations Industrial Development Organization (UNIDO), "Practical Guide for implementing an energy management system," Vienna: UNIDO, 78 pp, 2013.

[14] BS ISO 50006: 2014 Energy management systems-Measuring energy performance using energy baselines (EnB) and energy performance indicators (EnPI)-General principles and guidance, First edition, 2014-12-15.

[15] A. Hepbasli \& A. C. Arkon,"A New Exergy-based Index for Performance Assessment of Buildings", CLIMAMED 15, The Eighth Mediterranean Congress of Heating Ventilation and Air-Conditioning, Antibes Juan-les Pins, France, Sep. 2015.

[16] Yasar University-Energy Efficiency and Management, "Suggestion box," http://evy.yasar.edu.tr/en/suggestion-box/, Access date: 18 March 2017. 
$10^{\mathrm{TH}}$ InTERnAtional CONFERENCE ON Sustainable ENERgy AND Environmental Protection (June 27 $7^{\mathrm{TH}}-30^{\mathrm{TH}}, 2017$, BLed, SLOVENIA), ENERGy MANAGEMENT AND Policies

J. Krope, A.Ghani Olabi, D. Goričanec \& S. Božičnik

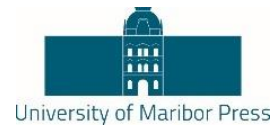

\title{
Long Term Energy Strategy Scenario to Promote 'Green' Electricity Against Natural Gas Consumption
}

\section{CRISTINA TAREAN}

\begin{abstract}
The paper aims to address national energy strategies scenarios in countries where energy consumption is based on mix of electricity from fossil fuels, renewable, natural gas or any other sources. Scope is to promote long term scenario that ensure sustainable development and promote decarbonisation. Availability of resources, consumption behaviour, price evolution, environment and climate change awareness and political and geostrategic position represents part of influencing factors when discussing about long term energy strategies. The paper promotes a long term scenario of Romanian energy system transformation by moving forward from conventional methods, for heating and cooking, towards solutions based on electricity generated from renewable sources. Looking for a 2050 scenario provides the opportunity to set up big goals in order to address big problems and transform our standard of living in a sustainable manner.
\end{abstract}

Keywords: - energy • renewables • strategy • 2050 scenario • transformation •

Correspondence AdDress: Cristina Tarean, Ph.D., Transformation Project Manager, E.ON Business Services, Newstead Court, Little Oak Drive, Annesley, NG15 0DR, Nottingham, UK, email: cristinatarean@gmail.com. 
$10^{\mathrm{TH}}$ INTERNATIONAL CONFERENCE ON SUSTAINABLE ENERGY AND ENVIRONMENTAL Protection (June $27^{\mathrm{TH}}-30^{\mathrm{TH}}, 2017$, Bled, Slovenia), Energy Management AND POLICIES

C. Tarean: Long Term Energy Strategy Scenario to Promote 'Green' Electricity Against Natural Gas Consumption

\section{$1 \quad$ Introduction}

In general, there is a consensus that natural gas combustion generates lower global warming emission compared with other fossil fuels and it's considered as a relative clean burning fossil fuel. [1], [2]

Furthermore the limited resources of natural gas must be addressed to understand the limitation in developing energy systems based on this type of fuel. Around the world, the highest reserves are concentrated in Russia, Middle East (Iran, Qatar, Saudi Arabia, Iraq) and America (U.S.A, Venezuela, Canada). [3] This paper will not address any other types of fossil fuels, like coal, as there are many discussions on the market around the impact of these fuels and a general acceptance about the need to transition towards renewable energy, as per most recent Paris Agreement from 2015, also known as $21^{\text {st }}$ yearly session of the Conference of the Parties (COP21).

The importance of challenging the natural gas usage is due to the limited reserves and geopolitics crisis that puts in a vulnerable position the countries that are dependent of imports. The residential sector represents the most vulnerable type of energy consumer from an energy security point of view. For residential sector the main usage of natural gas is for heating and cooking. A more recent event that affected a country dependent of natural gas imports from Russia is Ukraine. During winter period Russia has stopped gas deliveries to Ukraine putting the country in a difficult position. [4] Ukraine had national storage reserves to cover the demand but this example should be a lesson learned and countries should prepare to develop alternative solutions to energy imports.

\section{$2 \quad$ Research and Results}

The paper addresses the Romanian energy system due to its particularities of being almost completely reliant on national resources for natural gas. Although the current situation is very fortunate, the medium term estimations indicate the need for a different approach.

In order to proper develop a medium and long term energy scenario to promote renewable electricity shifts in Romania, the paper address further the energy profile, resource availability, climate profile and price differences for natural gas and electricity.

\subsection{Energy profile and resource availability}

In Romania, for 2015, natural gas consumption was assured from internal resources in percentage of $98.4 \%$ and the rest was represented by import as showed in figure 1 . The independence degree for coal was $80.4 \%$ and for oil was $37.6 \%$. 


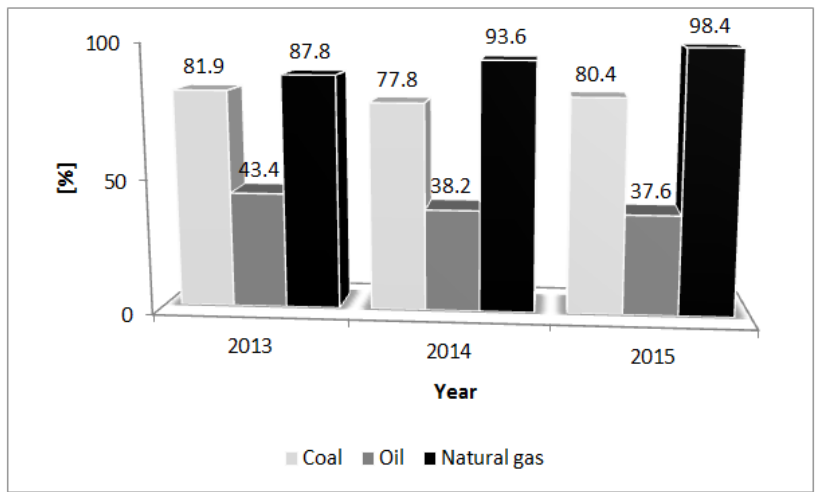

[Source: Modelled by author based on data from INSSE]

Figure 1. Romania energy independence degree

In 2015, the biggest consumer in the energy system was the residential sector $33.7 \%$; followed by industry $29.6 \%$, transport $25.5 \%$ and other $11.2 \%$ as represented in figure 2 .

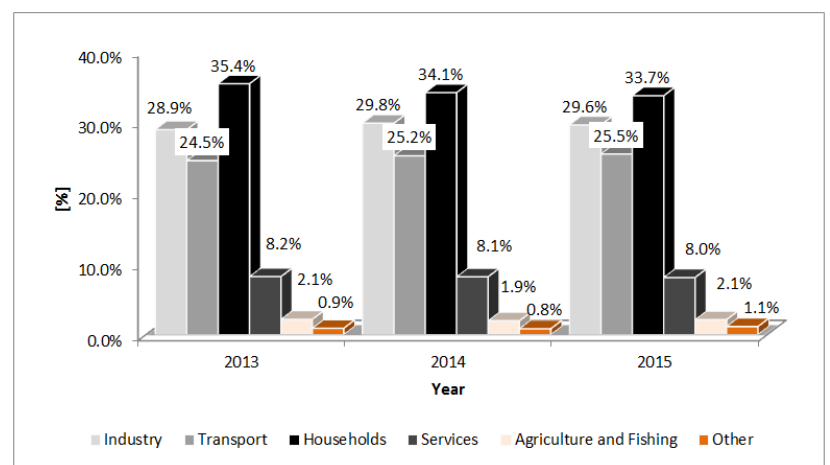

[Modelled by author based on European Commission data]

Figure 2. Final energy consumption by sector [14]

The national reserves of natural gas [5] were estimated to be sufficient for 15 years based on the yearly average production of 12.5 thousand tonnes.

In 2016, the Romanian Energy Minister finalised to update the current state for energy system [6] and based on a yearly average production of 11 billion cubic meters with a 5 $\%$ reduction of the reserves and $80 \%$ replacement rate of the natural gas reserves, it is estimated that this will be exhausted in 14 years.

Under the assumption that no new reserves will be discovered and exploited inside country territories, it is expected that Romania will have to find other natural gas sources around 2030 as shown in the figure 3. 
POLICIES

C. Tarean: Long Term Energy Strategy Scenario to Promote 'Green' Electricity Against

Natural Gas Consumption

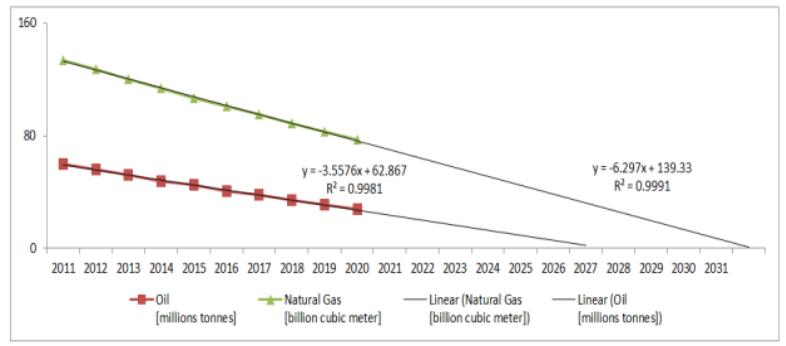

Source: Modelled by author based on data from ANRM

Figure 3. Romanian natural gas reserves evolution modelled with a linear trend line

The estimation model used is a linear regression line and, based on the value of the correlation coefficient $\mathrm{R}^{2}$ above 0.99 , the results are most reliable. The evolution is based on the assumption that no major events will occur in the next years.

World Energy Council, that is UN accredited, includes energy statistic for Romania, and, based on 2016 figures, indicates gas recoverable reserves of 99 [Mtoe] and, an annual production of 9.27 [Mtoe] which can indicate that if the trend is maintain then, in less than 10 years, Romania will exhaust the resources. [7]

In Romania, primary energy resources in 2015 were based on oil $28 \%$, natural gas $26 \%$, coal $14 \%$, hydro, nuclear and import electricity $13 \%$ and other types $18 \%$. [8] Based on the available data for the last 10 years, the first two most important resources were oil and natural gas representing more than $50 \%$ of the primary energy resources. Corroborated with the evolution of the availability, Romania must find alternative solution to ensure energy security for long term.

\subsection{Country climate profile}

Climate in Romania is temperate-continental with moderate features, with four seasons from which: winters are quite cold with average below $-15^{\circ} \mathrm{C}$ and, summers are very warm to hot and temperatures can go above $+35^{\circ} \mathrm{C}$. [9] The changes observed in Romania indicates an increase of yearly average of $+0.5^{\circ} \mathrm{C}$ from $8.8^{\circ} \mathrm{C}$ for $1961-1990$ period to $9.3^{\circ} \mathrm{C}$ for $1981-2014$ period. [10]

If this trend continues then it is expected further raise in Romania's temperature with impact on country's climate. Increase frequency for extreme meteorological events and warmer winter season will have an impact on yearly energy demand and will change the consumption behaviour.

Climate profile for winter season indicates the importance of energy resources availability for heating to ensure the health and safety of the residential sector but not limited at. 
$10^{\mathrm{TH}}$ INTERNATIONAL CONFERENCE ON SUSTAINABLE ENERGY AND ENVIRONMENTAL 47 Protection (June $27^{\mathrm{TH}}-30^{\mathrm{TH}}, 2017$, Bled, Slovenia), ENERgy MANAGEMENT AND POLICIES C. Tarean: Long Term Energy Strategy Scenario to Promote 'Green' Electricity Against Natural Gas Consumption

\subsection{Natural gas and electricity prices}

The main usage of energy for households is represented by heating due to cold winters. One main factor in choosing the energy supply type is represented by commodity price.

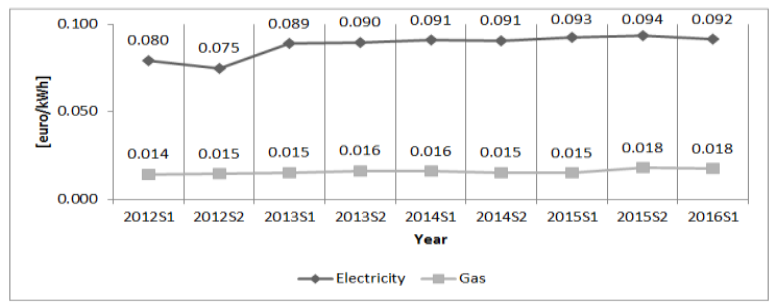

Source: Modelled by author based on Eurostat data

Figure 4. Households' electricity prices compared with natural gas prices for Romania (excluding taxes and levies, S1 and S2 represents the semesters)

The difference between electricity price and natural gas price is represented in figure 4 . The electricity prices are circa five times higher compared with natural gas.

However, this discrepancy is looking different if contractual prices are being compared and, in average, the electricity prices are three times higher than natural gas prices. The analysis was done on the two biggest companies (based on market share) from Romania by looking at their offers for households in 2017. [11] [12]

Analysis of the electricity and natural gas prices is not that simple as there are other factors to be considered when comparing the cost of using natural gas or electricity for households and, one of that is the efficiency of heating systems.

In average, for a 2 bedroom apartment, medium insulation, with a surface of circa $55 \mathrm{~m}^{2}$, during cold season it is estimate a monthly consumption of circa $3165 \mathrm{kWh}$ (300 cubic meter, based on ANRE statement) [13] for heating with natural gas and, circa $836 \mathrm{kWh}$ [14] for heating with electricity. Using the average prices from the two biggest energy companies from Romania, the cost of heating with electricity is lower with circa $10 \%$. This result supports the declaration of Mr. Nicolae Havrilet, the president of Romanian Energy Regulatory Authority (A.N.R.E.) when he stated that heating with electricity is with circa 50 lei (circa 10.1 euros) below natural gas cost per month during winter period. This estimations are average and the reality may show different results based on each consumer's profile and the efficiency of buildings.

Thinking on a long term, Naiping Zhu et al. research mentions a study by Shawkat et al. (2015) in which the correlation between natural gas, other energy prices, electricity prices and carbon emissions indicates that there is symmetrical effect between carbon gas and electricity prices, a negative correlation between natural gas prices and carbon prices and a positive correlation between electricity prices and carbon prices. [15] 
$10^{\mathrm{TH}}$ INTERNATIONAL CONFERENCE ON SUSTAINABLE ENERGY AND ENVIRONMENTAL Protection (June $27^{\mathrm{TH}}-30^{\mathrm{TH}}, 2017$, Bled, SLOVENiA), ENERGy MANAGEMENT AND POLICIES

C. Tarean: Long Term Energy Strategy Scenario to Promote 'Green' Electricity Against Natural Gas Consumption

D. Hulshof et al. research indicates that if the problems regarding international trade in electricity markets are solved, then a negative impact on the gas demand will affect the prices, as the gas-fired power plants will be switched off to allow an increase in the supply of renewable electricity. [16]

\subsection{Horizon 2050 - proposed scenario}

European Union and Romania, as member country, promotes through the document 'Energy Roadmap 2050' [17] a future in which the greenhouse gas emission are reduce by $80-95 \%$ by 2050 . In order to achieve this target, the energy system needs to go through a transformation and rely on emission free production.

In 2015 , renewable resources had represented $40.1 \%$ of gross electricity generation and $18.4 \%$ of the gross inland consumption. Starting with 2010, the renewable electricity generation capacity increased substantially due to investment schema supported by the government through legislation. The main generation capacity increased in 2015 compared with 2010 by: $256 \mathrm{MW}$ for hydro, $2741 \mathrm{MW}$ for wind and 1326 for solar PV. [18]

The political uncertainties are a constant factor that reminds that a country should prepare to be energetic independent and ensure people's well-being, secure, sustainable and affordable energy.

Considering a time Horizon of 2050, the proposal for a long term scenario is to transform the energy system by transitioning from natural gas consumption into renewable electricity consumption.

The scenario is based on two types of customers, figure 5: households and industry. The households customer are considered in two categories based on the volume of gas consumed: below 500 cubic meters per year will represents customers that are using natural gas for cooking; above 500 cubic meters per year represents customers that are using natural gas for cooking and heating.

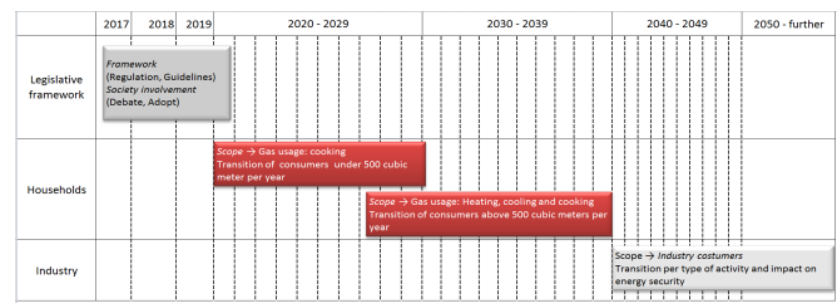

Figure 5. Romanian energy system transition roadmap 2050 
$10^{\mathrm{TH}}$ INTERNATIONAL CONFERENCE ON SUSTAINABLE ENERGY AND ENVIRONMENTAL 49 Protection (June $27^{\mathrm{TH}}-30^{\mathrm{TH}}, 2017$, Bled, Slovenia), ENERgy MANAGEMENT AND POLICIES C. Tarean: Long Term Energy Strategy Scenario to Promote 'Green' Electricity Against Natural Gas Consumption

The transition is planned per timeframes as follows:

- Present until 2020: preparatiobn phase to align legilative framework and engage society

- 2020 - 2030: transiton of consumers below 500 cubic meters per year, starting with new constructions and then the existing consumers.

- 2025 - 2040: transition of consumers above 500 cubic meter per year. Before transition starts there will a preparation phase.

- 2040 - onwards: transition phase for industry with the preparation phase before in which a planning per type of activity will be developed.

The scenario starts with residential consumers due to their vulnerability associated with any type of crisis that may impact resource availability.

A long time scenario and planning offers a timeframe in which, once the natural gas demand will decrease and, the electricity demand increases, the necessary generation capacity will be developed and integrated in an improved and modernized national grid system.

In Europe are similar types of examples and, one is Denmark with its objectives to supply $100 \%$ of its electricity mix from renewable energy by 2050. [19]

Sweden offers another example by its strategy to phase out natural gas in transportation and replace it with biogas by 2030. [20]

The transition towards electricity consumption will increase the electricity supply which shall lead to a reduction of prices but an increase in renewable generation capacity investments.

This type of scenario requires long terms commitment for investment and effort from the society and political cycles.

\section{Conclusions}

Transformation of a society it is not a fast process and radical changes should be debated at all levels and beyond political cycles. Long term changes should start with transparency and access to information. Education represents a high influential factor especially for environmental causes and climate change impact.

The paper addresses three influential factors but the discussion should go beyond. Society needs to be informed about resource availability and should be part of the decision making about the future of energy. 
$10^{\mathrm{TH}}$ INTERNATIONAL CONFERENCE ON SUSTAINABLE ENERGY AND ENVIRONMENTAL Protection (June $27^{\mathrm{TH}}-30^{\mathrm{TH}}, 2017$, Bled, Slovenia), Energy Management AND POLICIES

C. Tarean: Long Term Energy Strategy Scenario to Promote ‘Green’ Electricity Against Natural Gas Consumption

The analysis concluded that natural gas reserves will be exhausted by 2030 if no new sites are discovered and if the demand remains on the same trend. The yearly average temperature increased and this might have an impact of warmer winter period. The price comparison indicated that electricity is much expensive than natural gas but, based on the system efficiency, electricity heating is slightly cheaper that solutions based on natural gas, although this might be different based on the profile of each consumer.

In order to lower greenhouse gas emission, it is proposed to support investments in renewable energy that, in addition will provide energy security and energy independence on a long term.

One of the biggest benefits by switching to electric houses is the access to smart technology and innovation and the possibility of control by end user. For natural gas this option is restricted due to security challenges. The benefits of smart technologies will need to be further address as more and more smart meters will be installed.

In the end, long term planning represents a big challenge for society as most of the time the benefits will be for future generations based on the effort of current ones. A good understanding and engagement is essential for the success of long term strategies.

\section{Acknowledgements}

This paper represents further dedication from the author in raising the awareness for long term planning in energy and it is a continuation of the $\mathrm{PhD}$ thesis "Studies and research regarding energy strategies and policies in Romania in the context of sustainable development" published in 2016.

\section{References}

[1] U. o. C. Scientists. [Online]. Available: http://www.ucsusa.org/clean-energy/coal-andother-fossil-fuels/environmental-impacts-of-natural-gas. [Accessed March 2017].

[2] US Energy Information Administration. [Online]. Available: https://www.eia.gov/energyexplained/index.cfm/data/index.cfm?page=natural_gas_enviro nment. [Accessed March 2017].

[3] C. I. Agency, "The World Factbook: Natural Gas - Proved Reserves," [Online]. Available: https://www.cia.gov/library/publications/the-world-factbook/rankorder/2253rank.html. [Accessed March 2017].

[4] A. E. Kramer, "New York Times, Russia Cuts Off Gas Deliveries to Ukraine," 1 January $2009 . \quad$ [Online]. Available: http://www.nytimes.com/2009/01/02/world/europe/02gazprom.html. [Accessed March 2017].

[5] Ministerul Mediului, "Strategia Energica a Romaniei pentru perioada 2007 - 2020," 4 September 2007. [Online]. Available: www.minind.ro/energie/STRATEGIA_energetica_actualizata.pdf. [Accessed March 2017]. 
[6] Energy Ministery, “Analiza stadiului actual," 15 February 2016. [Online]. Available: http://energie.gov.ro/strategia-energetica-analiza-stadiului-actual-document-realizat-indata-de-12-04-2014/. [Accessed March 2017].

[7] World Energy Council, "Energy resources, Europe, Romania - gas," 2016. [Online]. Available: https://www.worldenergy.org/data/resources/country/romania/gas/. [Accessed March 2017].

[8] Institutul National De Statistica, "IND107A - Resursele de energie primara pe surse de provenienta si categorii de resurse," Romania, [Online]. Available: http://statistici.insse.ro/shop/index.jsp?page=tempo2\&lang=ro\&context=51. [Accessed March 2017].

[9] Romanian National Administration of Meteorology, "Climate of Romania," [Online]. Available: http://www.meteoromania.ro/anm2/clima/clima-romaniei/. [Accessed March 2017].

[10] I. Dr. Sandu, "Schimbari Climatice Observate Si Viitoare," in World day of Meteorology, Cunoasterea climei pentru prevenirea schimbarilor climatice, Bucharest, 2015.

[11] "E.ON Energie Romania," [Online]. Available: https://www.eon-energie-romania.ro/.

[12] "Engie Romania," [Online]. Available: https:/www.engie.ro/.

[13] "Digi 24 - ANRE recomandă încălzirea electrică în locul celei pe gaz," 14112013. [Online]. Available: http://www.digi24.ro/stiri/actualitate/social/anre-recomandaincalzirea-electrica-in-locul-celei-pe-gaz-152068. [Accessed March 2017].

[14] "Blog de Instalatii - Cum Aleg si Cat Consuma o Centrala Electrica?," 7 November 2015. [Online]. Available: http://blogdeinstalatii.ro/centrala-electrica/. [Accessed March 2017].

[15] N. Zhu, Q. Zhao, L. Tian and Q. Zhang, "Cost analysis and development strategies for China' natural gas power generation industry under the situation of energy price's reformation," Energy Procedia, no. 104, pp. 203 - 208, 2016.

[16] D. Hulshof, J.-P. v. d. Maat and M. Mulder, "Market fundamentals, competition and natural-gas prices,” Energy Policy, no. 94, pp. 480-491, 2016.

[17] European Commission, “Energy roadmap 2050," ISBN 978-92-79-21798-2, Luxemburg, 2012.

[18] European Commission, "Energy - Country datacheets - March 2017 update," March 2017. [Online]. Available: https://ec.europa.eu/energy/en/data-analysis/country. [Accessed March 2017].

[19] H. Lund and B. Mathiesen, "Energy system analysis of $100 \%$ renewable energy systems The case of Denmark in years 2030 and 2050," Energy, no. 34(5), pp. 524 - 531, 2009.

[20] European Biogas Association, 08 May 2015. [Online]. Available: http://europeanbiogas.eu/2015/05/08/sweden-on-the-way-to-phase-out-natural-gas-from-the-transportsector/. [Accessed March 2017]. 
$52 \quad 10^{\text {TH }}$ INTERNATIONAL CONFERENCE ON SUSTAINABLE ENERGY AND ENVIRONMENTAL

Protection (June $27^{\mathrm{TH}}-30^{\mathrm{TH}}, 2017$, Bled, Slovenia), Energy Management And

POLICIES 
$10^{\mathrm{TH}}$ InTERnational CONFERENCE ON Sustainable ENERgy AND

ENVIRONMENTAL Protection (June $27^{\mathrm{TH}}-30^{\mathrm{TH}}$, 2017, Bled, SLOVENIA), ENERGy MANAGEMENT AND Policies

J. Krope, A.Ghani Olabi, D. Goričanec \& S. Božičnik

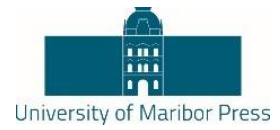

\title{
A Hybrid Solar/Wind/Biofuel Management Strategy in Iran Using Techno-Econo-Socio-Environmental Multivariate Analysis (TESEMA)
}

\author{
Pouya IFAEI, JOUAN RASHIDI, JEONG TAI KIM \& CHANGKYOO YOO
}

\begin{abstract}
A comprehensive renewable energies management strategy is proposed for Iran considering various technical, economic, social and environmental variables. Accordingly, hybrid solar/wind/biofuel systems are optimally designed at each Iranian meteorological site to meet the local power demand. Having obtained the electrical share of each renewable source under optimal conditions, eight other variables are obtained including net present costs, population density, air pollution, unemployment rate, land use and price, population, and industrial development factor to set up a data base for techno-econo-socioenvironmental multivariate analysis (TESEMA). Principal components analysis is done to reduce the variability dimensions and hierarchical and non-hierarchical clustering are performed to classify the case study with regard to the sustainability variables. The results showed that together, the first three and five principal components represent $66.1 \%$ and $81.4 \%$, respectively, of the total variability while Iran can be effectively classified in five clusters with respect to the TESEMA results.
\end{abstract}

Keywords: • clustering $\bullet$ hybrid solar/wind/biofuel system $\bullet$ management strategy $\bullet$ Principal components analysis • TESEMA •

CorResPondence AdDress: Pouya Ifaei, Ph.D, student, Kyung Hee University, Dept. of Environmental Science and Engineering, Seocheon-dong 1, Giheung-gu, Yongin-Si, GyeonggiDo, 446-701, Korea, e-mail: pouya.ifaei@khu.ac.kr. Jouan Rashidi, Ph.D, student, Kyung Hee University, Dept. of Environmental Science and Engineering, Seocheon-dong 1, Giheung-gu, Yongin-Si, Gyeonggi-Do, 446-701, Korea, e-mail: jouanra@gmail.com. Jeong Tai Kim, Ph.D., Professor, Kyung Hee University, Department of agricultural engineering, Suwon-si, Gyeongi-do, South Korea, e-mail: jtkim@khu.ac.kr. ChangKyoo Yoo, Ph.D, professor, Kyung Hee University, Dept. of Environmental Science and Engineering, Seocheon-dong 1, Giheung-gu, Yongin-Si, Gyeonggi-Do, 446-701, Korea, e-mail: ckyoo@khu.ac.kr. 
$10^{\mathrm{TH}}$ INTERNATIONAL CONFERENCE ON SUSTAINABLE ENERGY AND ENVIRONMENTAL Protection (June $27^{\mathrm{TH}}-30^{\mathrm{TH}}, 2017$, Bled, Slovenia), Energy Management AND POLICIES

P. Ifaei, J. Rashidi, J. Tai Kim \& C. Yoo: A Hybrid Solar/Wind/Biofuel Management Strategy in Iran Using Techno-Econo-Socio-Environmental Multivariate Analysis (TESEMA)

Sustainable development is undoubtedly the main global concern in the modern world which is significantly endangered by resources depletion and environmental situation degradation [1]. A holistic sustainable plan can be achieved if and only if all involved aspects are considered and probable threats are predicted. Such a concise plan requires considerable scientific efforts especially in the case of developing countries. Thus, many researchers have concentrated on the problem in the recent years and promising progresses have been made in various fields of concern.

Soflaei et al. [2] studied two ancient civilizations, China and Iran, to investigate the potential of traditional courtyard houses in responding to environmental challenges. Their review extracted useful socio-environmental and socio-cultural lessons from the past architectural principles. However, economic aspects were not included. Compton and Rezaei [3] performed and enviro-exergy sustainability analysis in the USA. Their analysis results revealed that biofuel is preferred compared to the natural gas from both economic and environmental viewpoints. The interest in biomass as a sustainable replacement of the conventional fossil fuels have been increased in the recent years. The main reasons can be described as high global warming potential of methane and the advances in more economic utilization of the sources [4]. However, other researchers focused on the social and economic issues as sustainability parameters rather than the renewable energy sources. From this point of the view green energies are assumed to be zero carbon emission sources [5]. However, zero emissions during the plant operation does not mean an absolute non-carbon system considering a cradle-to-grave assessment of the power generation systems. Hence, confident environmental results could be obtained as a full life cycle assessment is conducted. In this way, Evans et al. [6] proposed several sustainability indicators for renewable and non-renewable energy sources considering greenhouse gas emissions, land requirements, the cost of electricity, water consumption and other social impacts.

Similar studies have been done in Iran since the sustainable growth is under question in the energy-intensive country. The researchers have mentioned energy security, water scarcity, policies, and risks in Iran but a comprehensive study proposing a management strategy has not been published yet [7]. On the other hand, the assessment approaches have been devoted to a solo-resource such as wind power and a hybrid assessment approach considering the renewable sources potential simultaneously is scarce [8].

Having reviewed the literature, energy-based sustainable growth has been widely studied but a comprehensive study analysing all technical, economic, social, and environmental variables has not been published to the knowledge of the authors.

The aim of the current paper is to study the hybrid solar/wind/biofuel energy potential in Iran considering effective technical, economic, social, and environmental variables. 
P. Ifaei, J. Rashidi, J. Tai Kim \& C. Yoo: A Hybrid Solar/Wind/Biofuel Management Strategy in Iran Using Techno-Econo-Socio-Environmental Multivariate Analysis

Thus, techno-econo-socio-environmental multivariate analysis (TESEMA) is detailed for Iran using multivariate statistical techniques. The paper consists of four major parts. In the first part, the case study is briefly introduced. In the second part, the simulation approach is detailed. In the third part the required variables and analysis are explained and in the fourth part the TESEMA application results are discussed.

\section{$2 \quad$ Materials and Methods}

TESEMA is detailed and verified in Iran in the following sections.

\subsection{Case study background}

Iran is the $18^{\text {th }}$ largest country in the world which holds approximately $17 \%$ of the global natural gas reserves [9]. Since 97\% of domestic energy demand is met using the fossil fuels and the rest by the hydro power, the country has faced serious environmental hazards [10]. On the other hand the energy demand is considerably high in Iran so that the energy consumption per capita is 10 times higher than that of the European Union [11]. Thus, the government is determined in renewable energy harnessing for which a strategy plan is required.

The political division of Iran and the representative sites in the current study are shown in Figure 1. According to the figure, thirty sites are selected and the required hourly temperature, global horizontal radiation, and wind speed are obtained from the corresponding meteorological stations.

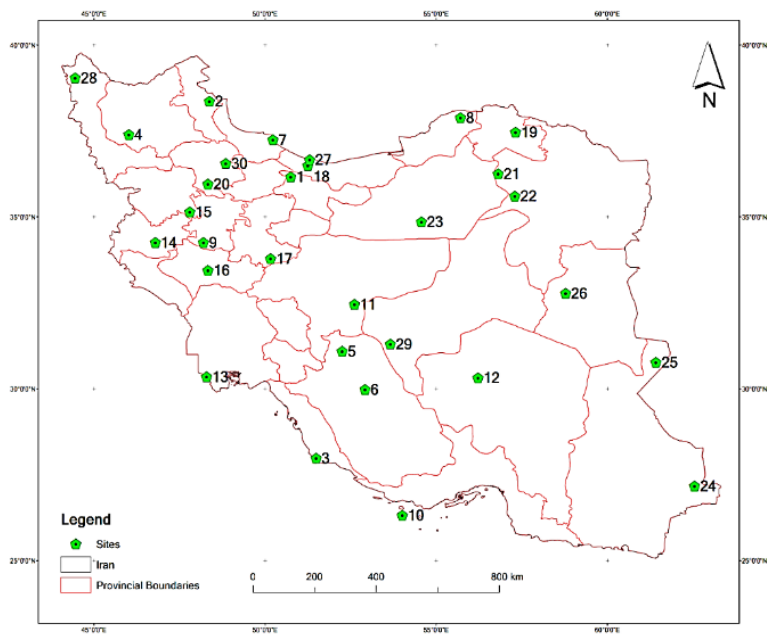

Figure 1. Representative meteorological sites location in Iran 
$10^{\mathrm{TH}}$ INTERNATIONAL CONFERENCE ON SUSTAINABLE ENERGY AND ENVIRONMENTAL

Protection (June $27^{\mathrm{TH}}-30^{\mathrm{TH}}, 2017$, Bled, Slovenia), Energy Management AND POLICIES

P. Ifaei, J. Rashidi, J. Tai Kim \& C. Yoo: A Hybrid Solar/Wind/Biofuel Management Strategy in Iran Using Techno-Econo-Socio-Environmental Multivariate Analysis (TESEMA)

The geographical locations of the sites are given in Table 1 . The required solar and wind data are detailed in refs. [12] and [8], respectively. The amount of biogas is obtained for a 200 people community as detailed in ref. [13].

Table 1. Representative sites coordinates

\begin{tabular}{|c|c|c|c|c|}
\hline No. & Site & Province & Location & Elev. \\
\hline 1 & Taleghan & Alborz & $\begin{array}{l}50.75^{\circ} \mathrm{E}, \\
36.17^{\circ} \mathrm{N}\end{array}$ & 1,842 \\
\hline 2 & Namin & Ardabil & $\begin{array}{l}48.37{ }^{\circ} \mathrm{E}, \\
38.37^{\circ} \mathrm{N}\end{array}$ & 1,425 \\
\hline 3 & Bardkhoon & Bushehr & $\begin{array}{l}51.49{ }^{\circ} \mathrm{E}, \\
27.98^{\circ} \mathrm{N}\end{array}$ & 14 \\
\hline 4 & Bonab & $\begin{array}{l}\text { East- } \\
\text { Azerbaijan }\end{array}$ & $\begin{array}{ll}46.02 & { }^{\circ} \mathrm{E}, \\
37.4^{\circ} \mathrm{N} & \end{array}$ & 1,286 \\
\hline 5 & Abade & Fars & $\begin{array}{l}52.25{ }^{\circ} \mathrm{E}, \\
31.09^{\circ} \mathrm{N}\end{array}$ & 2,030 \\
\hline 6 & Marvdasht & fars & $\begin{array}{l}52.92{ }^{\circ} \mathrm{E}, \\
29.98^{\circ} \mathrm{N}\end{array}$ & 2,170 \\
\hline 7 & Langrood & Gilan & $\begin{array}{l}50.23{ }^{\circ} \mathrm{E}, \\
37.25^{\circ} \mathrm{N}\end{array}$ & -17 \\
\hline 8 & Marave Tappe & Golestan & $\begin{array}{l}55.71{ }^{\circ} \mathrm{E}, \\
37.89^{\circ} \mathrm{N}\end{array}$ & 219 \\
\hline 9 & Nahavand & Hamedan & $\begin{array}{l}48.2{ }^{\circ} \mathrm{E}, \\
34.26^{\circ} \mathrm{N}\end{array}$ & 1,655 \\
\hline 10 & Kish & Hormozgan & $\begin{array}{l}54.01{ }^{\circ} \mathrm{E}, \\
26.32^{\circ} \mathrm{N}\end{array}$ & 33 \\
\hline 11 & Varzaneh & Isfahan & $\begin{array}{l}52.61{ }^{\circ} \mathrm{E}, \\
32.46^{\circ} \mathrm{N}\end{array}$ & 1,548 \\
\hline 12 & Rafsanjan & Kerman & $\begin{array}{l}56.22{ }^{\circ} \mathrm{E}, \\
30.32^{\circ} \mathrm{N}\end{array}$ & 1,546 \\
\hline 13 & Abadan & Khuzestan & $\begin{array}{l}48.29{ }^{\circ} \mathrm{E}, \\
30.35^{\circ} \mathrm{N}\end{array}$ & 3 \\
\hline 14 & Mahi Dasht & Kermanshah & $\begin{array}{l}46.79{ }^{\circ} \mathrm{E}, \\
34.26^{\circ} \mathrm{N}\end{array}$ & 1,362 \\
\hline 15 & Ghorveh & Kordestan & $\begin{array}{l}47.8{ }^{\circ} \mathrm{E}, \\
35.15^{\circ} \mathrm{N}\end{array}$ & 1,788 \\
\hline 16 & Khorramabad & Lorestan & $\begin{array}{l}48.33{ }^{\circ} \mathrm{E}, \\
33.45^{\circ} \mathrm{N}\end{array}$ & 1,166 \\
\hline 17 & Khomeyn & Markazi & $\begin{array}{l}50.16{ }^{\circ} \mathrm{E}, \\
33.79^{\circ} \mathrm{N}\end{array}$ & 1,811 \\
\hline 18 & Senar & Mazandaran & $\begin{array}{ll}51.25 & { }^{\circ} \mathrm{E}, \\
36.5^{\circ} \mathrm{N} & \\
\end{array}$ & 1,204 \\
\hline
\end{tabular}


P. Ifaei, J. Rashidi, J. Tai Kim \& C. Yoo: A Hybrid Solar/Wind/Biofuel Management Strategy in Iran Using Techno-Econo-Socio-Environmental Multivariate Analysis

(TESEMA)

\begin{tabular}{|c|c|c|c|c|}
\hline 19 & Bojnurd & \begin{tabular}{|l} 
North- \\
Khorasan \\
\end{tabular} & $\begin{array}{l}57.32{ }^{\circ} \mathrm{E}, \\
37.47^{\circ} \mathrm{N}\end{array}$ & 1,071 \\
\hline 20 & Shurjeh & Qazvin & $\begin{array}{l}48.33{ }^{\circ} \mathrm{E}, \\
35.96^{\circ} \mathrm{N}\end{array}$ & 1,596 \\
\hline 21 & Davarzan & $\begin{array}{l}\text { Razavi- } \\
\text { Khorasan }\end{array}$ & $\begin{array}{l}56.81{ }^{\circ} \mathrm{E}, \\
36.26^{\circ} \mathrm{N}\end{array}$ & 900 \\
\hline 22 & Rudab & $\begin{array}{l}\text { Razavi- } \\
\text { Khorasan }\end{array}$ & $\begin{array}{l}57.3{ }^{\circ} \mathrm{E}, \\
35.61^{\circ} \mathrm{N}\end{array}$ & 1,281 \\
\hline 23 & Moalleman & Semnan & $\begin{array}{l}54.57{ }^{\circ} \mathrm{E}, \\
34.86^{\circ} \mathrm{N}\end{array}$ & 711 \\
\hline 24 & Dehak & $\begin{array}{l}\text { Sistan and } \\
\text { Baluchistan }\end{array}$ & $\begin{array}{l}62.55{ }^{\circ} \mathrm{E}, \\
27.17^{\circ} \mathrm{N}\end{array}$ & 1,072 \\
\hline 25 & Lutak & $\begin{array}{l}\text { Sistan and } \\
\text { Baluchistan }\end{array}$ & $\begin{array}{l}61.42{ }^{\circ} \mathrm{E}, \\
30.77^{\circ} \mathrm{N}\end{array}$ & 749 \\
\hline 26 & Fadashk & $\begin{array}{l}\text { South- } \\
\text { Khorasan }\end{array}$ & $\begin{array}{l}58.78{ }^{\circ} \mathrm{E}, \\
32.78^{\circ} \mathrm{N}\end{array}$ & 1,327 \\
\hline 27 & Hesarak & Tehran & $\begin{array}{l}51.3{ }^{\circ} \mathrm{E}, \\
36.67^{\circ} \mathrm{N}\end{array}$ & 1,594 \\
\hline 28 & Chaldoran & $\begin{array}{l}\text { West- } \\
\text { Azerbaijan }\end{array}$ & $\begin{array}{l}44.45{ }^{\circ} \mathrm{E}, \\
39.05^{\circ} \mathrm{N}\end{array}$ & 1,829 \\
\hline 29 & Abarkuh & Yazd & $\begin{array}{ll}53.66 & { }^{\circ} \mathrm{E}, \\
31.3^{\circ} \mathrm{N} & \end{array}$ & 1,511 \\
\hline 30 & Soltanye & Zanjan & $\begin{array}{l}48.855^{\circ} \mathrm{E}, \\
36.56^{\circ} \mathrm{N}\end{array}$ & 1,797 \\
\hline
\end{tabular}

\subsection{Hybrid solar/wind/biofuel system simulation}

The hybrid solar/wind/biofuel system is shown in Figure 2. The hybrid system consists of solar photovoltaic (PV), wind turbine (WT), biogas generator (BG), converter, and battery (storage) components. The off-grid hybrid system is capable of generating at least one $\mathrm{kW}$ of power in each hour so it can be used as a gauge system which indicates the necessary size of the renewable system to meet the energy demand in each site under optimal conditions. The annual amount of extra energy is reported as the excess power in each site.

The required economic parameters are summarized in Table 2. The system is simulated using HOMER PRO software. Thus, a hybrid system is optimally designed in each site and net present cost of the system is obtained using Equation (1) as follows:

$$
N P C=\frac{T A C}{C R F}
$$


$10^{\mathrm{TH}}$ INTERNATIONAL CONFERENCE ON SUSTAINABLE ENERGY AND ENVIRONMENTAL Protection (June $27^{\mathrm{TH}}-30^{\mathrm{TH}}, 2017$, Bled, Slovenia), Energy Management AND POLICIES

P. Ifaei, J. Rashidi, J. Tai Kim \& C. Yoo: A Hybrid Solar/Wind/Biofuel Management Strategy in Iran Using Techno-Econo-Socio-Environmental Multivariate Analysis (TESEMA)

Where, NPC is the net present cost, TAC is the total annualized costs and CRF is the capital recovery factor.

Table 2. Economic parameters

\begin{tabular}{|l|l|}
\hline parameter & value \\
\hline BG capital costs & $5,000 \$$ \\
\hline BG replacement costs & $1,250 \$$ \\
\hline BG maintenance costs & $875 \$$ year \\
\hline WT capital costs & $3,950 \$$ \\
\hline WT replacement costs & $3,450 \$$ \\
\hline WT maintenance costs & $60 \$$ year \\
\hline PV capital costs & $3,500 \$$ \\
\hline PV replacement costs & $3,000 \$$ \\
\hline PV maintenance costs & $25 \$$ year \\
\hline battery capital costs & $600 \$$ \\
\hline battery replacement costs & $600 \$$ \\
\hline battery maintenance costs & $10 \$ /$ year \\
\hline converter capital costs & $1,100 \$$ \\
\hline converter replacement costs & $600 \$$ \\
\hline Project lifetime & 25 years \\
\hline Nominal discount rate & $10 \%$ \\
\hline Expected inflation rate & $10 \%$ \\
\hline
\end{tabular}

Thus, the NPC, excess power, solar fraction (SF), and wind fraction (WF) are obtained in each site under optimal conditions. It goes without saying that the biogas fraction can be calculated according to SF and WF so that the sum of three variables ends up to the unity. The required land for the system is obtained using Equation (2) in each site.

$$
\text { system }_{\text {area }}=\sum C U S . C N
$$

Where, CUS is the components unit size, and $\mathrm{CN}$ is the components number. The converter, solar and wind components unit size are assumed to be $1.2,10$ and $25 \mathrm{~m}^{2}$, respectively [14]. The size of biogas and battery components are neglected because the biogas size is fixed for all sites and the batteries can be mounted on the inverter components. 
P. Ifaei, J. Rashidi, J. Tai Kim \& C. Yoo: A Hybrid Solar/Wind/Biofuel Management Strategy in Iran Using Techno-Econo-Socio-Environmental Multivariate Analysis

(TESEMA)

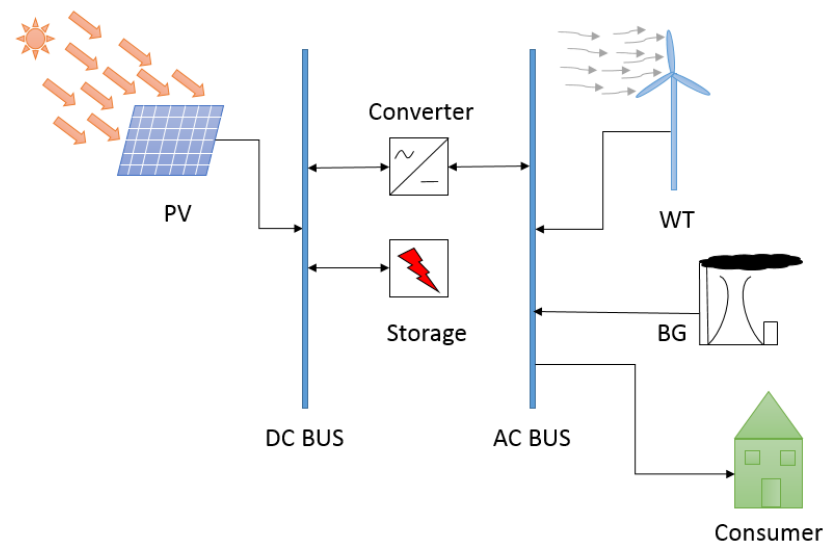

Figure 2. Schematic representation of the hybrid system

\subsection{Non-simulated variables}

Non-simulated required economic, social and environmental variables are summarized in Table 3. According to the table, air quality is obtained regarding the department of environment report in 2015. Industrial development score indicates the industrial growth in a province. Population, population density, and unemployment rate are other socioeconomic variables followed by the land price. Note that the provinces with more than one representative sites are reported only once. 
P. Ifaei, J. Rashidi, J. Tai Kim \& C. Yoo: A Hybrid Solar/Wind/Biofuel Management Strategy in Iran Using Techno-Econo-Socio-Environmental Multivariate Analysis (TESEMA)

Table 3. Non-simulated variables

\begin{tabular}{|c|l|l|l|l|l|l|}
\hline $\begin{array}{c}\text { site } \\
\text { No. }\end{array}$ & $\begin{array}{l}\text { Air } \\
\text { qual. }\end{array}$ & $\begin{array}{l}\text { Ind. } \\
\text { Dev. }\end{array}$ & $\begin{array}{l}\text { Populati } \\
\text { on }\end{array}$ & $\begin{array}{l}\text { Pop. } \\
\text { Den. }\end{array}$ & $\begin{array}{l}\text { Un. } \\
\text { rate }\end{array}$ & $\begin{array}{l}\text { Ln. } \\
\text { Pr. }\end{array}$ \\
\hline 1 & 406 & 2019 & 2712.4 & 465 & 12.4 & 136 \\
\hline 2 & 302 & 1368 & 1270.4 & 70.8 & 12.8 & 80 \\
\hline 3 & 428 & 16581 & 1163.4 & 51.1 & 9.7 & 39 \\
\hline 4 & 304 & 2019 & 3909.6 & 85.9 & 7.3 & 115 \\
\hline 5 & 274 & 2150 & 4851.2 & 39.6 & 12.1 & 90 \\
\hline 7 & 296 & 1092 & 2530.6 & 180 & 11 & 65 \\
\hline 8 & 315 & 1181 & 1868.6 & 91.7 & 11.8 & 43 \\
\hline 9 & 372 & 1264 & 1738.2 & 89.7 & 8.5 & 77 \\
\hline 10 & 274 & 11420 & 1776.4 & 25.1 & 11.9 & 90 \\
\hline 11 & 398 & 2944 & 5120.8 & 47.8 & 13.8 & 132 \\
\hline 12 & 324 & 2963 & 3164.7 & 17.4 & 7.9 & 47 \\
\hline 13 & 622 & 4788 & 4710.5 & 73.5 & 10.9 & 78 \\
\hline 14 & 464 & 1939 & 1952.4 & 78.1 & 17.6 & 70 \\
\hline 15 & 448 & 1402 & 1603.1 & 56.8 & 13.3 & 73 \\
\hline 16 & 496 & 1081 & 1760.6 & 62.2 & 13.3 & 48 \\
\hline 17 & 380 & 2974 & 1429.4 & 48.4 & 7.9 & 114 \\
\hline 18 & 296 & 1802 & 3283.5 & 138 & 1.02 & 52 \\
\hline 19 & 318 & 1629 & 863.1 & 30.3 & 11.1 & 68 \\
\hline 20 & 406 & 2033 & 1273.7 & 81.9 & 11.7 & 105 \\
\hline 21 & 394 & 1422 & 6434.5 & 54.1 & 13.3 & 74 \\
\hline 23 & 396 & 1915 & 702.3 & 7.2 & 8.4 & 73 \\
\hline 24 & 405 & 1321 & 2775.1 & 9.9 & 11.5 & 60 \\
\hline 26 & 408 & 1380 & 768.9 & 5.1 & 8.6 & 60 \\
\hline 27 & 412 & 2547 & 13268 & 1022 & 8.1 & 903 \\
\hline 28 & 304 & 1098 & 3265.2 & 881 & 10.9 & 76 \\
\hline 29 & 386 & 2459 & 1138.5 & 148.9 & 11.2 & 51 \\
\hline 30 & 348 & 1523 & 1057.4 & 48.6 & 9.6 & 97 \\
\hline
\end{tabular}

\section{$2.4 \quad$ Multivariate analysis}

Having obtained more than 10 techno-econo-socio-environmental variable for thirty sites, principal component analysis (PCA) is performed in order to reduce the complexity of input variables. PCA is a mature multivariate statistical method which reduces the dimensions of variables using a Varimax rotation [15].

Following the PCA, the simulated and non-simulated variables are clustered to classify the observations in the sites. A k-means algorithm is used to cluster the variables. Finally, an average linkage similarity hierarchical clustering method is applied to depict the 
P. Ifaei, J. Rashidi, J. Tai Kim \& C. Yoo: A Hybrid Solar/Wind/Biofuel Management Strategy in Iran Using Techno-Econo-Socio-Environmental Multivariate Analysis

(TESEMA)

clusters graphically. The clustering approaches are constructed according to the Euclidean similarity level between the variables [16].

\section{$3 \quad$ Results and Discussion}

The simulation results are summarized in Table 4 for which the NPC and land use are in $\mathrm{M} \$$ and $\mathrm{m}^{2}$, respectively. In order to obtain a uniform data set, a multiple of the reciprocals of the land price, land use and NPC are used for statistical analyses instead of the reported values. In this way, the greater the variable quantity is, the greater the renewable energies priority becomes. Thus, greater value of air quality leads to higher priority of renewable energies application as zero carbon sources.

The scree plot of PCA is shown in Figure 3. According to PCA results, the first PC has an eigenvalue of 2.8651 which accounts for $28.7 \%$ of total variance. The first to the seventh PCs have $97.1 \%$ of cumulative variance. Thus, the significance of the last three PCs seems negligible. The variability can be efficiently captured in three underlying dimensions because an eyebrow occurs in the third PC.

Table 4. Simulation results and corresponding clusters

\begin{tabular}{|c|l|l|l|l|l|l|}
\hline No. & NPC & SF & WF & Ln. use & $\begin{array}{l}\text { Clus } \\
\text { ter }\end{array}$ & Ln. use \\
\hline 1 & 3.31 & 53.57 & $\begin{array}{l}32.2 \\
5\end{array}$ & 4590 & A & 4590 \\
\hline 2 & 3.21 & 65.93 & $\begin{array}{l}24.4 \\
6\end{array}$ & 3650 & C & 3650 \\
\hline 3 & 3.17 & 77.72 & 9.6 & 2860 & C & 2860 \\
\hline 4 & 4.09 & 94.8 & 0.2 & 4980 & A & 4980 \\
\hline 5 & 3.09 & 86.96 & 0.91 & 2400 & D & 2400 \\
\hline 6 & 3.24 & 82.73 & 3.75 & 2770 & D & 2770 \\
\hline 7 & 3.83 & 88.26 & 0.16 & 3700 & A & 3700 \\
\hline 8 & 3.08 & 57.49 & $\begin{array}{l}36.1 \\
9\end{array}$ & 4175 & B & 4175 \\
\hline 9 & 3.43 & 88.17 & 0.08 & 2920 & B & 2920 \\
\hline 10 & 3.07 & 68.57 & $\begin{array}{l}21.8 \\
1\end{array}$ & 3605 & B & 3605 \\
\hline 11 & 3.07 & 94.3 & 0.13 & 2590 & D & 2590 \\
\hline 12 & 3.07 & 70.82 & $\begin{array}{l}22.5 \\
9\end{array}$ & 4000 & A & 4000 \\
\hline 13 & 3.28 & 53.61 & $\begin{array}{l}33.2 \\
5\end{array}$ & 4020 & D & 4020 \\
\hline 14 & 3.43 & 94.23 & 0.08 & 3360 & B & 3360 \\
\hline 15 & 3.32 & 89.21 & 0.15 & 2775 & B & 2775 \\
\hline & & & & & \\
\hline 1.09 & & & & & \\
\hline
\end{tabular}


$62 \quad 10^{\mathrm{TH}}$ INTERNATIONAL CONFERENCE ON SUSTAINABLE ENERGY AND ENVIRONMENTAL Protection (June $27^{\mathrm{TH}}-30^{\mathrm{TH}}, 2017$, Bled, Slovenia), Energy Management AND POLICIES

P. Ifaei, J. Rashidi, J. Tai Kim \& C. Yoo: A Hybrid Solar/Wind/Biofuel Management Strategy in Iran Using Techno-Econo-Socio-Environmental Multivariate Analysis (TESEMA)

\begin{tabular}{|l|l|l|l|l|l|l|}
\hline 16 & 3.15 & 71.4 & $\begin{array}{l}19.4 \\
9\end{array}$ & 3530 & B & 3530 \\
\hline 17 & 3.22 & 87.46 & 0.07 & 2455 & B & 2455 \\
\hline 18 & 3.45 & 38.87 & $\begin{array}{l}49.2 \\
7\end{array}$ & 4665 & A & 4665 \\
\hline 19 & 2.93 & 61.77 & $\begin{array}{l}26.6 \\
3\end{array}$ & 3540 & C & 3540 \\
\hline 20 & 3.27 & 60.25 & $\begin{array}{l}25.8 \\
2\end{array}$ & 4075 & C & 4075 \\
\hline 21 & 3.04 & 77.14 & $\begin{array}{l}18.0 \\
7\end{array}$ & 3710 & D & 3710 \\
\hline 22 & 5.4 & 87.84 & 1.36 & 4030 & D & 4030 \\
\hline 23 & 3.08 & 88.76 & 0.53 & 2400 & C & 2400 \\
\hline 24 & 3.16 & 86.75 & 0.29 & 2490 & A & 2490 \\
\hline 25 & 3.11 & 78.95 & $\begin{array}{l}13.1 \\
9\end{array}$ & 3085 & A & 3085 \\
\hline 26 & 2.98 & 74.5 & $\begin{array}{l}20.4 \\
9\end{array}$ & 3765 & C & 3765 \\
\hline 27 & 3.43 & 65.2 & $\begin{array}{l}24.4 \\
1\end{array}$ & 4135 & E & 4135 \\
\hline 28 & 3.42 & 86.21 & $\begin{array}{l}13.6 \\
7\end{array}$ & 2955 & $\begin{array}{l}\text { Out } \\
\text { lier }\end{array}$ & 2955 \\
\hline 29 & 3.08 & 77.13 & 6.31 & 3645 & E & 3645 \\
\hline 30 & 3.09 & 90.39 & 0.22 & 2360 & C & 2360 \\
\hline
\end{tabular}

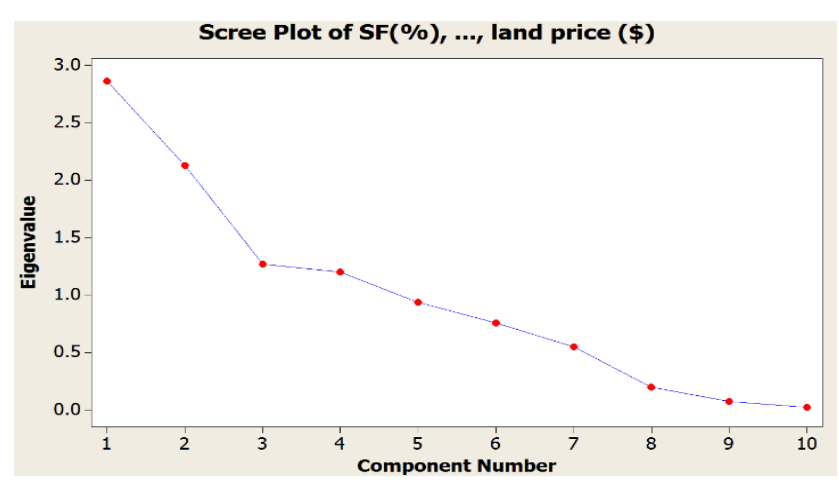

Figure 3. Scree plot of PCA

K-means clustering results are summarized in the last column of Table 4. Considering site No. 28 as an outlier, the sites can be effectively clustered in 5 clusters. The sites of a cluster can be treated in a similar way from the management viewpoint. The clustering results can also be used to construct hybrid RE and sustainability maps of Iran. 
P. Ifaei, J. Rashidi, J. Tai Kim \& C. Yoo: A Hybrid Solar/Wind/Biofuel Management Strategy in Iran Using Techno-Econo-Socio-Environmental Multivariate Analysis

(TESEMA)

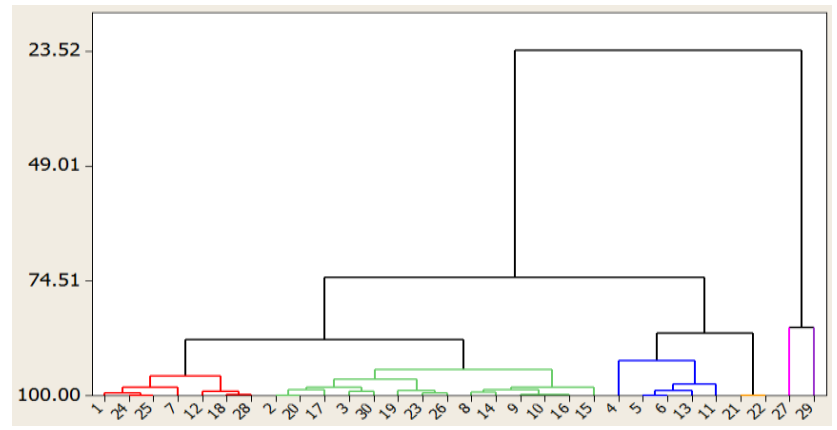

Figure 4. Scree plot of PCA

The dendrogram of the hierarchical clustering using an average linkage method is shown in Figure 4 for which the vertical axis represents the similarity level and the horizontal axis accounts for the sites. According to the figure, 14 sites can be classified in a cluster with a common energy management strategy.

\section{$4 \quad$ Conclusion}

Techno-econo-socio-environmental multivariate analysis was applied to Iran in order to set up a management strategy for hybrid solar/wind/biofuel systems. Accordingly thirty meteorological sites were selected and the corresponding ten minute weather data were used. Solar and wind fractions of the optimal hybrid system were assumed as technical variables in addition to land price, land use, unemployment rate, industrial development, air quality, population, population density and net present cost to form the variables data set. PCA and K-means were applied and the following conclusion was driven

- Iran can be effectively classified in five clusters;

- Three principal components represent $66.1 \%$ of the total variability among the variables; thus

- A three stages management strategy can be applied to Iran.

The results of the study can be used for the as hybrid renewable and sustainability maps of Iran and the analysis can be further extended to any regions of interest in the world.

\section{Acknowledgements}

This work was supported by a National Research Foundation of Korea (NRF) grant funded by the Korean government (MSIP) (No.2015R1A2A2A11001120).

\section{References}

[1] X.Y. Liu, G.Y. Liu, Z.F. Yang, B. Chen, S. Ulgiati. Comparing national environmental and 
$10^{\mathrm{TH}}$ INTERNATIONAL CONFERENCE ON SUSTAINABLE ENERGY AND ENVIRONMENTAL Protection (June $27^{\mathrm{TH}}-30^{\mathrm{TH}}, 2017$, Bled, SLOVENiA), ENERGy MANAGEMENT AND POLICIES

P. Ifaei, J. Rashidi, J. Tai Kim \& C. Yoo: A Hybrid Solar/Wind/Biofuel Management Strategy in Iran Using Techno-Econo-Socio-Environmental Multivariate Analysis (TESEMA)

economic performances through emergy sustainability indicators: Moving environmental ethics beyond anthropocentrism toward ecocentrism. Renew Sust Energ Rev. 58 (2016) 1532-42.

[2] F. Soflaei, M. Shokouhian, W.Y. Zhu. Socio-environmental sustainability in traditional courtyard houses of Iran and China. Renew Sust Energ Rev. 69 (2017) 1147-69.

[3] M. Compton, B. Rezaie. Enviro-exergy sustainability analysis of boiler evolution in district energy system. Energy. 119 (2017) 257-65.

[4] S. Bracco. Effectiveness of EU biofuels sustainability criteria in the context of land acquisitions in Africa. Renew Sust Energ Rev. 50 (2015) 130-43.

[5] S. Cho, J. Kim. Feasibility and impact analysis of a renewable energy source (RES)-based energy system in Korea. Energy. 85 (2015) 317-28.

[6] A. Evans, V. Strezov, T.J. Evans. Assessment of sustainability indicators for renewable energy technologies. Renew Sust Energ Rev. 13 (2009) 1082-8.

[7] Z. Bakhtiyari, M. Yazdanpanah, M. Forouzani, N. Kazemi. Intention of agricultural professionals toward biofuels in Iran: Implications for energy security, society, and policy. Renew Sust Energ Rev. 69 (2017) 341-9.

[8] P. Alamdari, O. Nematollahi, M. Mirhosseini. Assessment of wind energy in Iran: A review. Renew Sust Energ Rev. 16 (2012) 836-60.

[9] S. Gorjian, B. Ghobadian. Solar desalination: A sustainable solution to water crisis in Iran. Renew Sust Energ Rev. 48 (2015) 571-84.

[10] S. Farzin, P. Ifaei, N. Farzin, Y. Hassanzadeh, M.T. Aalami. An Investigation on Changes and Prediction of Urmia Lake water Surface Evaporation by Chaos Theory. Int J Environ Res. 6 (2012) 815-24.

[11] G. Najafi, B. Ghobadian, R. Mamat, T. Yusaf, W.H. Azmi. Solar energy in Iran: Current state and outlook. Renew Sust Energ Rev. 49 (2015) 931-42.

[12] P. Alamdari, O. Nematollahi, A.A. Alemrajabi. Solar energy potentials in Iran: A review. Renew Sust Energ Rev. 21 (2013) 778-88.

[13] Z. Rashidi, A.R. Karbassi, A. Ataei, P. Ifaei, R. Samiee-Zafarghandi, M.J. Mohammadizadeh. Power Plant Design Using Gas Produced By Waste Leachate Treatment Plant. Int J Environ Res. 6 (2012) 875-82.

[14] T. Hong, M. Lee, C. Koo, J. Kim, K. Jeong. Estimation of the Available Rooftop Area for Installing the Rooftop Solar Photovoltaic (PV) System by Analyzing the Building Shadow Using Hillshade Analysis. Energy Procedia. 88 (2016) 408-13.

[15] R. Noori, M.S. Sabahi, A.R. Karbassi, A. Baghvand, H.T. Zadeh. Multivariate statistical analysis of surface water quality based on correlations and variations in the data set. Desalination. 260 (2010) 129-36.

[16] R. Azimi, M. Ghayekhloo, M. Ghofrani. A hybrid method based on a new clustering technique and multilayer perceptron neural networks for hourly solar radiation forecasting. Energy Conversion and Management. 118 (2016) 331-44. 


\title{
The Impact of the European Electricity Market Regulation on Environmental Adjusted Productivity: Evidence from 10 Selected Countries Between 1995 and 2013
}

\author{
TEODORA DIANA CORSATEA
}

\begin{abstract}
Using an environmental adjusted productivity framework technical efficiencies are examined within the electricity and gas sector, in the context of the sector's reforms between 1995 and 2013 and over a panel of 10 European countries. The econometric strategy proposes a stochastic frontier estimation of a multiple output distance function of one desirable output (gross output) and three undesirable outputs (CO2, N2O and CH4 emissions). The investigation suggests that the liberalisation of the energy markets was responsible for empowering vertical separations in the supply chain to significantly influence the sector's variability of technical inefficiency. Results suggest that vertical integration contributed negatively to inefficiency's variability during that period. The decomposition of the productivity change in efficiency change and technical progress, suggests that the latter was the main source of productivity growth within the traditional single output productivity framework; however, within an environmental productivity measurement, it turns out that the sector has the potential for productivity gains from resource reallocation through the reduction of market distortions.
\end{abstract}

Keywords: • electricity and gas sector $\bullet$ emissions $\bullet$ stochastic frontier analysis $\bullet$ technical efficiency change $\bullet$ productivity change $\bullet$

CORRESPONDENCE ADDRESS: Teodora Diana Corsatea, Directorate B5, Circular Economy and Industrial Leadership, European Commission, Inca Garcilaso 3, E-41092, Seville, Spain: email: Teodora.corsatea@ec.europa.eu. 
$10^{\mathrm{TH}}$ INTERNATIONAL CONFERENCE ON SUSTAINABLE ENERGY AND ENVIRONMENTAL Protection (June $27^{\mathrm{TH}}-30^{\mathrm{TH}}, 2017$, Bled, Slovenia), Energy Management AND POLICIES

T. D. Corsatea: The Impact of the European Electricity Market Regulation on Environmental Adjusted Productivity: Evidence from 10 Selected Countries Between 1995 and 2013

Energy transition, as a concept incorporated in many policy measures, carries different interpretations across countries: whilst for some countries the concept refers to the level of carbon intensity, for others it relates to the process of liberalisation of energy markets [1]. Many energy policy measures were introduced as a means of correcting market failures that can generate suboptimal investments in the energy sector. For example, the energy packages introduced from the mid1990s aimed at greater openness of the European energy markets, ownership unbundling, independence of regulators and cross border transmission of electricity $[2,3]$. A consequence of the regulatory changes, the legal and functional unbundling occurring in the sector was acknoledged as having positive impacts, through induced price reduction [4]. Other regulatory incentives, such as the ones stimulating the diffusion of renewable energy sources ${ }^{1}$ and increased energy efficiency enabled the most carbon intensive European industries to successfully reduce their emissions ${ }^{2}$. The transition to a more competitive framework together with environmental policies seeking low-carbon technology diffusion possibly favoured productivity and efficiency changes in specific segments of the energy supply chain.

The present investigation explores the extent to which productivity changes and deviations from the production frontier depended on efforts focused on market liberalization. It uses efficiency and productivity as two different concepts, with productivity changes incorporating both technical efficiency changes and technical progress. The analysis adds to the studies on decomposition of productivity change previously examined by growth accounting [5, 6]; stochastic frontier [7], linear programming $[8,9]$ or DEA [10]. These studies expand the traditional framework for studying productivity by including resources that are devoted to pollution abatement or, otherwise, a part of the outputs that should be sacrificed for a cleaner environment [8]. The use of a stochastic frontier approach $[11,12]$ allows the expansion of the framework for studying environmental productivity and adds a vector of institutional variables, such as regulation, explaining the variability of inefficiencies in the energy sector.

The econometric strategy proposes a panel data analysis of an output distance function across 10 European countries, from 1995 to 2013 and using as inputs capital, labour, one desirable output (gross output) and three undesirable outputs $\left(\mathrm{CO}_{2}, \mathrm{~N}_{2} \mathrm{O}\right.$ and $\mathrm{CH}_{4}$ emissions). The estimates are further used to estimate environmental productivity changes for the electricity and gas sector, one of the most polluting sectors during that period of time, yet one for which new opportunities for growth are identified. The structure of the work is as follows. Section 2 presents the data and model specifications. Section 3 discusses the results and policy implications. Finally, Section 4 concludes. 
$10^{\mathrm{TH}}$ INTERNATIONAL CONFERENCE ON SUSTAINABLE ENERGY AND ENVIRONMENTAL Protection (June $27^{\mathrm{TH}}-30^{\mathrm{TH}}, 2017$, Bled, Slovenia), ENERgy MANAGEMENT AND

T. D. Corsatea: The Impact of the European Electricity Market Regulation on Environmental Adjusted Productivity: Evidence from 10 Selected Countries Between 1995 and 2013

\section{Data, Methodology and Model Specification}

The estimation of productivity and efficiency changes usually involves additional assumptions pertaining to model specifications, distributional assumptions and temporal behaviour of inefficiency. The use of a multi-output distance function relaxes several data limitations, such as the need for prices for the bad outputs, or the need for weights used in the case of multiple outputs; a specification using output distance functions assures a joint estimation of multiple outputs, informing of the maximum that can be achieved given a set of inputs and subject to specific constraints.

Related to the inefficiency term, distributional assumptions of inefficiency are needed in the case of panel data analysis in order to separate inefficiency from noise. Different approaches invite different assumptions in order to deal with limits raised by nonparametric approaches or by sequential analysis, assumptions that might contradict the assumption of identically distributed residuals [11]; these inconveniences can be addressed by a simultaneous estimation in the framework of the Stochastic Frontier Approach (SFA) [11]. The use of the SFA allows the parametrising of the variance of the one-sided inefficiency error component, and thus achieving additional insights into the relationships of the inefficiency with various determinants [13]. The model was also augmented with the inclusion of entities' specific intercepts [14]. Inspiring from all these models, the paper considers a translog multiple output distance function(eq 1), where $i$ and $t$ are subscripts for countries and years respectively

$$
\begin{aligned}
& -\ln \left(y_{1, i t}\right)=\alpha_{i}+\sum_{m} \alpha_{m} \ln \left(\frac{y_{m i t}}{y_{1, i t}}\right)+0.5 * \\
& \sum_{m} \sum_{n} \beta_{m n} \ln \left(\frac{y_{m, i t}}{y_{1, i t}}\right) \ln \left(\frac{y_{n, i t}}{y_{1, i t}}\right)+\sum_{k} \gamma_{m} \ln x_{k, i t}+ \\
& \quad+0.5 * \sum_{k} \sum_{l} \beta_{k . l} \ln x_{k t} \ln x_{l i t}+\sum_{m} \alpha_{m} P M R+\theta t+\vartheta t * \ln x_{k i t}-u_{i t}+v_{i t}
\end{aligned}
$$

The translog output function was defined for $\mathrm{k}=2$ inputs $\left(x_{k, i}\right)$ and $\mathrm{m}=3\left(y_{m i}\right)$ outputs including the following assumptions [8] i) the shadow prices of the bad outputs should reflect the sacrifice of the good outputs for obtaining a cleaner environment; ii) an additional specification reflects the trade-off between the good and the bad output iii) when it is non-increasing in the inputs, for fixed quantities of the good and bad outputs, more inputs decrease the value of the distance function. The constraint of constant returns to scale seems unrealistic in the context of the current investigation and hence is not considered for this analysis. The negative sign of the explanatory variables reflects the distance from the frontier. The model allows for true fixed effects $\alpha_{i}$ [14].

Last, the inefficiency is distributed half normal $\mathrm{u}_{\mathrm{it}} \sim \mathrm{N}^{+}\left(\mu_{\mathrm{it}}, \sigma_{\mathrm{u}, \mathrm{it}}^{2}\right)=\mathrm{N}^{+}\left(\delta_{\mathrm{o}}+\right.$ $\left.\mathrm{z}_{\mathrm{u}, \mathrm{it}} \delta, \exp \left(\mathrm{w}_{\mathrm{uo}}+\mathrm{z}_{\mathrm{u}, \mathrm{it}} \mathrm{w}_{\mathrm{u}}\right)\right)$ and the error term as $\mathrm{v}_{\mathrm{it}} \sim N\left(0, \sigma_{v, i t}^{2}\right)$, where the technical 
T. D. Corsatea: The Impact of the European Electricity Market Regulation on Environmental Adjusted Productivity: Evidence from 10 Selected Countries Between 1995 and 2013

efficiency equals $\exp \left(-u_{i t}\right)$ ). The inefficiency term $u_{i t}$ is quite sensitive to how it is modelled [15]: the inclusion of the measures relating to the regulatory stance of countries enables transitions induced in the (in)efficiency within the energy sector to be understood. Productivity is measured as the relative performance of the units across different units of time, also incorporating changes due to technical progress. Departing from DebreuFarrell's definition of technical efficiency and deriving it in time, the paper decomposes the productivity change into technical progress and efficiency change in a similar manner to previous studies (Minh et al., 2012).

\section{$3 \quad$ Results}

The patterns of the gross output $y_{1, i t}$ of Sector D "Electricity, gas and water supply", the patterns of the bad outputs $y_{m, i t}\left(\mathrm{CO}_{2}, \mathrm{CH}_{4}, \mathrm{~N}_{2} \mathrm{O}\right.$ emissions) and the patterns of the inputs (K, L) controlling for market regulation (PMR) are explored between 1995 and 2013 over a panel of 10 countries: Austria, Belgium, Denmark, Finland, France Germany, Italy, Spain, Sweden and the UK. The EUKLEMS was used as the data source for the sectorial gross output, the capital services and the labour services series across-countries and time [16]. The information on pollutant' emissions for Sector D was collected from Eurostat (Air Accounts, 2008-2013) and completed with the WIOD environmental accounts (Genty et al 2012) in order to account for the residence-based system of accounting.

Measures of countries' regulatory stance over time are reflected by the product market regulation indicators produced by the OECD [15]. To determine the extent to which these regulatory efforts affected the variability of the efficiency is the aim of the present exploration. In particular, whether the indicators on barriers to entry, public ownership, market structure and vertical integration played a role upon productivity and efficiency gains was tested.

The time varying inefficiency, controlling for country fixed effects was estimated based on previous studies [17] and using the specification from equation (1) that allows the use of a multiple output framework.

Table 1 displays the estimates of the different specifications, one allowing the inclusion of several pollutants (hereafter called environmental) and controlling for the country's regulation in the electricity sector. This specification has been compared to single output specification. 
$10^{\mathrm{TH}}$ INTERNATIONAL CONFERENCE ON SUSTAINABLE ENERGY AND ENVIRONMENTAL 69 Protection (June $27^{\mathrm{TH}}-30^{\mathrm{TH}}, 2017$, Bled, Slovenia), ENERgy MANAGEMENT AND POLICIES

T. D. Corsatea: The Impact of the European Electricity Market Regulation on Environmental Adjusted Productivity: Evidence from 10 Selected Countries Between 1995 and 2013

Table 1. Stochastic frontier estimates : single output versus multiple outputs specification

\begin{tabular}{|c|c|c|c|c|c|c|}
\hline & & $\begin{array}{l}\text { Single } \\
\text { output } \\
\text { homos } \\
\text { cedasti } \\
\text { c } \\
\text { ineffici } \\
\text { ency- } \\
\text { (1)- }\end{array}$ & $\begin{array}{l}\text { Multipl } \\
\text { e } \\
\text { output, } \\
\text { homosc } \\
\text { edastic } \\
\text { inefficie } \\
\text { ncy (2) }\end{array}$ & $\begin{array}{l}\text { Multipl } \\
\text { e } \\
\text { output } \\
\text { heteros } \\
\text { cedastic } \\
\text { inefficie } \\
\text { ncy - } \\
\text { (3)- }\end{array}$ & $\begin{array}{l}\text { Multip } \\
\text { le } \\
\text { output } \\
\text { hetero } \\
\text { skedas } \\
\text { tic } \\
\text { ineffici } \\
\text { ency - } \\
\text { (4)- }\end{array}$ & $\begin{array}{l}\text { Multiple } \\
\text { output } \\
\text { heterosk } \\
\text { edastic } \\
\text { inefficie } \\
\text { ncy -(5)- } \\
\text { eq.1 }\end{array}$ \\
\hline & Capital & $\begin{array}{c}0.40 \\
{[0.22] \mathrm{n}}\end{array}$ & $\begin{array}{c}0.29 \\
{[0.21] \mathrm{n} .}\end{array}$ & $\begin{array}{c}-0.36 \\
{[0.22] \mathrm{n} .}\end{array}$ & $\begin{array}{c}-0.50 \\
{[0.41] \mathrm{n}}\end{array}$ & $\begin{array}{c}-0.29 \\
{[0.52] \mathrm{n} . \mathrm{s}}\end{array}$ \\
\hline & (log scale) & .s. & S. & & & \\
\hline & $\begin{array}{l}\text { Labour } \\
\text { services } \\
\text { (log scale) }\end{array}$ & $\begin{array}{c}-0.63 \\
{[0.09]^{*}} \\
* *\end{array}$ & $\begin{array}{c}-0.68 \\
{[0.08]^{* *}} \\
*\end{array}$ & $\begin{array}{c}-0.21 \\
{[0.11]^{*}}\end{array}$ & $\begin{array}{c}-0.53 \\
{[0.21]^{*}} \\
*\end{array}$ & $\begin{array}{c}-0.24 \\
{[0.60] \mathrm{n} . \mathrm{s}} \\
.\end{array}$ \\
\hline & $\begin{array}{l}\text { Capital*la } \\
\text { bour } \quad(\log \\
\text { scale) }\end{array}$ & & & & & $\begin{array}{c}-0.20 \\
{[0.16] \mathrm{n} . \mathrm{s}} \\
.\end{array}$ \\
\hline & $\begin{array}{l}\text { Ratio } \mathrm{CO} 2 \\
\text { to gross } \\
\text { output(log } \\
\text { scale) }\end{array}$ & & $\begin{array}{c}0.19 \\
{[0.06]^{* *}} \\
*\end{array}$ & $\begin{array}{c}0.21 \\
{[0.09]^{* *}}\end{array}$ & $\begin{array}{l}0.08 \\
{[] \mathrm{ns}}\end{array}$ & $\begin{array}{c}0.13 \\
{[0.16] \mathrm{n} . \mathrm{s}} \\
.\end{array}$ \\
\hline & $\begin{array}{l}\text { Ratio N2O } \\
\text { to gross } \\
\text { output(log } \\
\text { scale) }\end{array}$ & & $\begin{array}{c}-0.04 \\
{[0.09] \mathrm{n} .} \\
\text { s. }\end{array}$ & $\begin{array}{c}0.28 \\
{[0.15]^{*}}\end{array}$ & $\begin{array}{c}0.69 \\
{[0.23]^{*}} \\
*\end{array}$ & $\begin{array}{c}0.60 \\
{[0.23]^{* *}}\end{array}$ \\
\hline & $\begin{array}{l}\text { Ratio ch4 } \\
\text { to gross } \\
\text { output(log } \\
\text { scale) }\end{array}$ & & $\begin{array}{c}0.84 \\
{[0.07]^{* *}} \\
*\end{array}$ & $\begin{array}{c}0.50 \\
{[0.12]^{* *}} \\
*\end{array}$ & $\begin{array}{c}0.22 \\
{[0.15]}\end{array}$ & $\begin{array}{c}0.26 \\
{[0.15]^{*}}\end{array}$ \\
\hline & $\begin{array}{l}\text { Ratio } \\
\text { CO2* } \\
\text { Ratio Ch4 }\end{array}$ & & $\begin{array}{c}-0.06 \\
{[0.01]^{* *}} \\
*\end{array}$ & $\begin{array}{c}-0.06 \\
{[0.02]^{* *}} \\
*\end{array}$ & $\begin{array}{c}-0.05 \\
{[0.23]^{*}} \\
*\end{array}$ & $\begin{array}{c}-0.01 \\
{[.021]^{* *}}\end{array}$ \\
\hline 光 & $\begin{array}{l}\text { Ratio } \\
\mathrm{CO} 2 * \text { Ratio } \\
\mathrm{N} 2 \mathrm{O}\end{array}$ & & $\begin{array}{c}0.02 \\
{[0.01] \mathrm{n} .} \\
\text { s. }\end{array}$ & $\begin{array}{c}0.04 \\
{[0.02]^{* *}}\end{array}$ & $\begin{array}{c}0.06 \\
{[0.03]^{*}}\end{array}$ & $\begin{array}{c}0.06 \\
{[0.03]^{*}}\end{array}$ \\
\hline อี & $\begin{array}{l}\text { Ratio } \\
\mathrm{CO} 2 * \text { Ratio } \\
\mathrm{N} 2 \mathrm{O}\end{array}$ & & $\begin{array}{c}0.04 \\
{[0.01]^{* *}} \\
*\end{array}$ & $\begin{array}{c}0.01 \\
{[0.01] \mathrm{n} .} \\
\mathrm{s} .\end{array}$ & $\begin{array}{c}-0.01 \\
{[0.02] \mathrm{n}} \\
. \mathrm{s}\end{array}$ & $\begin{array}{c}0.01 \\
{[0.01] \mathrm{n} . \mathrm{s}} \\
.\end{array}$ \\
\hline & Trend & -0.05 & -.03 & -0.02 & -0.01 & -0.01 \\
\hline
\end{tabular}


T. D. Corsatea: The Impact of the European Electricity Market Regulation on Environmental Adjusted Productivity: Evidence from 10 Selected Countries Between 1995 and 2013

\begin{tabular}{|c|c|c|c|c|c|}
\hline & \multicolumn{3}{|c|}{$[0.0]^{* *}[0.00]^{* *}[0.00]^{* *}$} & {$[0.01] \mathrm{n}$} & {$[0.0]$ n.s. } \\
\hline & $*$ & $*$ & $*$ &.$s$ & \\
\hline $\begin{array}{l}\text { Fixed } \\
\text { effects }\end{array}$ & Yes & yes & Yes & Yes & yes \\
\hline Entry & & & & $\begin{array}{c}0.004 \\
{[0.02] \mathrm{n}} \\
. \mathrm{s}\end{array}$ & \\
\hline $\begin{array}{l}\text { Vertical } \\
\text { integration }\end{array}$ & & & $\begin{array}{c}-0.09 \\
{[0.03]^{* *}} \\
*\end{array}$ & & \\
\hline Entry & & & & $\begin{array}{c}-0.91 \\
{[0.71] \mathrm{n}} \\
. \mathrm{s}\end{array}$ & $\begin{array}{c}-0.99 \\
{[0.47]^{* *}}\end{array}$ \\
\hline $\begin{array}{l}\text { Public } \\
\text { ownership }\end{array}$ & & & & & $\begin{array}{c}-0.04 \\
{[0.24] \mathrm{n} . \mathrm{s}}\end{array}$ \\
\hline $\begin{array}{l}\text { Vertical } \\
\text { integration }\end{array}$ & & & $\begin{array}{c}-1.62 \\
{[0.40]^{* *}} \\
*\end{array}$ & & $\begin{array}{c}-0.86 \\
{[0.54]^{*}}\end{array}$ \\
\hline $\begin{array}{l}\text { Market } \\
\text { structure }\end{array}$ & & & & & $\begin{array}{c}-0.29 \\
{[0.24] \mathrm{n} . \mathrm{s}}\end{array}$ \\
\hline Constant & $\begin{array}{l}-4.46 \\
{[0.35]^{*}} \\
* *\end{array}$ & $\begin{array}{l}-5.10 \\
{[0.52]^{* *}} \\
*\end{array}$ & $\begin{array}{c}3.27 \\
{[1.79]^{*}}\end{array}$ & $\begin{array}{c}-4.19 \\
{[2.21]^{*}}\end{array}$ & $\begin{array}{c}0.79 \\
{[2.39] \mathrm{n} . \mathrm{s}} \\
.\end{array}$ \\
\hline Constant & $\begin{array}{l}-5.67 \\
{[0.3]^{* *}} \\
*\end{array}$ & $\begin{array}{l}-5.82 \\
{[0.35] * *} \\
*\end{array}$ & $\begin{array}{c}-5.18 \\
{[0.33]^{* *}} \\
*\end{array}$ & $\begin{array}{c}-3.75 \\
{[0.4]^{* *}} \\
*\end{array}$ & $\begin{array}{c}-4.31 \\
{[0.32]^{* *}} \\
*\end{array}$ \\
\hline
\end{tabular}

N.B. Standard errors in brackets and * $10 \%$ significance level, ** 5\% significance level and $* * * 1 \%$ significance level.

The models presented in the table build incrementally one on top of the other. First, they seek a correction of environmental damages, by including different pollutants within the multiple output distance function, and constraining them to a radial expansion, that is respecting conditions i),ii and iii). Secondly, the specifications include the variables reflecting product market regulation and affecting the variance of the inefficiency term. The negative signs are interpreted as contributions that help reduce the distance from the frontier. Significant positive estimates are shown for pollutants (e.g. $\mathrm{CO}_{2}, \mathrm{CH}_{4}, \mathrm{~N}_{2} \mathrm{O}$ emissions) and indicate the amount of resources used for the abatement of pollution. 
$10^{\mathrm{TH}}$ INTERNATIONAL CONFERENCE ON SUSTAINABLE ENERGY AND ENVIRONMENTAL Protection (June $27^{\mathrm{TH}}-30^{\mathrm{TH}}, 2017$, Bled, Slovenia), ENERgy MANAGEMENT AND

POLICIES

T. D. Corsatea: The Impact of the European Electricity Market Regulation on Environmental Adjusted Productivity: Evidence from 10 Selected Countries Between 1995 and 2013

Technical progress. The single output model specification revealed a positive and significant contribution of the technical progress, approximated by the trend (5\%). However, its contribution decreases in environmental specifications becoming even not significant (Model 5, Table1) .

\section{The reorganisation of the energy sector: production gains versus efficiency gains.}

The period of analysis features the implementation of the liberalisation framework, sought to allow transition from nationally vertically integrated monopolies to more competitive markets. Some concerns over the functioning of these markets were raised in the sense that limitations to market penetration of the new entrants could have negatively affected production, yet this effect was found not statistically significant (model 3, table1).

Certain characteristics of the sector are potentially harmful to electricity output and the sectors' efficiency gains. For example, high rates of public ownership could impede the entrance of firms able to assure better allocations. However, this effect was not confirmed by present specifications (model 5, Table1).

Considering only the effect of vertical separations over the energy sector (specification 3 ) it turns out that vertical relationships contributed positively to the output growth, whilst on the efficiency side, vertical relationships contributed negatively to the inefficiency's variability. The latter recalls the slow pace of reforms in the sector with respect to the separation of functions belonging to different segments of the energy supply chain. Among the indicators examined, all countries manifested higher regulation intensity with respect to vertical integration and public ownership compared to entry and market structure. Insufficient unbundling between supply and transmission activities might not allow economies of scope $^{3}$ to reduce inefficiencies. This hypothesis will be further studied by changing the distributional assumptions of the one side inefficiency term. Finally, the investigation suggests that the liberalization of the energy markets was responsible for empowering vertical separations in the supply chain to significantly influence the sector's variability of technical efficiency.

\section{Efficiency patterns}

An empirical indication of the performance of the energy sector, which does not differentiate between idiosyncratic errors and the inefficiency term, is possible using the information from countries' energy balances. The technical efficiency of the overall energy sector was calculated as a ratio between the transformation output and transformation input. Comparing the estimation results with this deterministic measure, it appeared that the most exhaustive specification (model 5) featured a technical efficiency change close to the one determined through the use of energy balances. Ttests were also employed to test the differences in the means of efficiency changes 
T. D. Corsatea: The Impact of the European Electricity Market Regulation on Environmental Adjusted Productivity: Evidence from 10 Selected Countries Between 1995 and 2013

between the ratio derived from the energy balances $(-0.3 \%$ on average) and the ones based on stochastic frontier estimations; the results indicated greater closeness of the means when using the multiple output regulated specification $(-0.4 \%$ on average).

\section{Productivity change}

The patterns of efficiency change are incorporated into the productivity change, bearing important policy insights. In the single output specification, the growth of productivity is less explained by the efficiency change ( $0.3 \%$ on average) and more by the technical change (5\%). In the multi-output specification, the technical progress contributes on average $2.5 \%$ to productivity changes, or even becomes statistically insignificant in the presence of regulation (models 4, 5, Table 1).

The environmental productivity change is lower than the single output one, indicating that, without the inclusion of the cost of pollution, the analysis framework understates the true productivity improvement in industries that have been devoting an increasing share of resources to pollution abatement activities. The evolution of the average multiple output productivity patterns affected by the market regulation is shown in Figure 1.

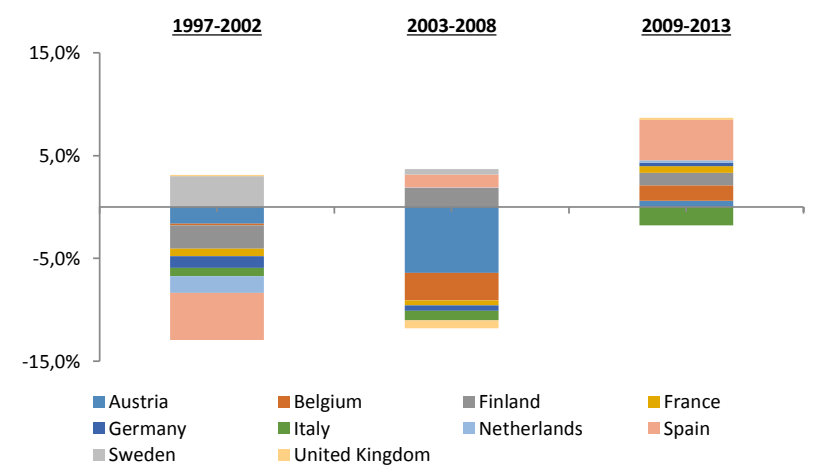

Figure 1 Average environmental productivity patterns by country, controlling for the market regulation affecting the inefficiency's variability

The regulatory components exerted a positive contribution on the production side through the changes in vertical integration. However, the joint contribution of regulation to the inefficiency's variance was negative, and significant only with respect to vertical integration and entry. The patterns in productivity change should be carefully examined as they reflect the joint effect of energy market regulation and the level of pollution abatement occurring in these countries. 
$10^{\mathrm{TH}}$ INTERNATIONAL CONFERENCE ON SUSTAINABLE ENERGY AND ENVIRONMENTAL 73 Protection (June $27^{\mathrm{TH}}-30^{\mathrm{TH}}, 2017$, Bled, Slovenia), ENERgy MANAGEMENT AND POLICIES

T. D. Corsatea: The Impact of the European Electricity Market Regulation on Environmental Adjusted Productivity: Evidence from 10 Selected Countries Between 1995 and 2013

\section{$4 \quad$ Conclusion}

The efforts directed towards market liberalisation and low-carbon transition sought to correct market failures negatively affecting investments. The analysis shows that the choice of the policy measures plays an important role in explaining the variability of technical inefficiency and also in the productivity changes.

Furthermore, the analysis used an environmentally expanded framework. Without the inclusion of the cost of pollution, the analysis understates the true productivity improvement in industries that have been devoting an increasing share of resources to pollution abatement activities. Stricter environmental regulations in one country lead to a higher opportunity cost between bad and good outputs, and greater effort within specific countries to comply. This effect needs to be accounted for in the context of an industry opening to competition with the final aim of a single market.

Also, one sees the need for incorporation of the role of market regulation as a means to decrease distortions that could generate resource reallocations across countries and increase aggregate productivity.

The effects on productivity change resulting from the interplay between the market regulation and the environmental goals (i.e. lower emissions) could contribute to providing responses for correcting structural weaknesses in the overall business climate. The design of policy measures, hence, accounting for different facets of the production process is not only a relevant question for a top-down design of policy measures. It is also interesting from a bottom-up perspective, in which firms and smaller entities empowered by a liberalised framework would reallocate resources towards greener growth.

\section{Disclaimer}

The views expressed in this paper are purely those of the writer and may not in any circumstances be regarded as stating an official position of the European Commission.

\section{Notes}

1 Up to $27.5 \%$ from gross electricity production in 2014, source Eurostat http://ec.europa.eu/eurostat/statistics-explained/index.php/Europe_2020_indicators_-

_climate_change_and_energy

2 based on territorial accounting, it appears that in 2014 energy sectors reduced by $24.8 \%$ CO2 emissions under 1990 levels

3( i.e. cost reduction when controlling various segments of the supply chain 
$10^{\mathrm{TH}}$ INTERNATIONAL CONFERENCE ON SUSTAINABLE ENERGY AND ENVIRONMENTAL Protection (June $27^{\mathrm{TH}}-30^{\mathrm{TH}}, 2017$, Bled, Slovenia), Energy Management AND POLICIES

T. D. Corsatea: The Impact of the European Electricity Market Regulation on Environmental Adjusted Productivity: Evidence from 10 Selected Countries Between 1995 and 2013

\section{References}

[1] G. Bridge, S. Bouzarovski, M. Bradshaw and N. Eyre, "Geographies of energy transition: Space, place and the low-carbon economy," Energy Policy, vol. 53, pp. 331-340, 2013.

[2] Directive72/2009, "EC of the European Parliament and of the Council of 13 July 2009 concerning common rules for the internal market in electricity and repealing Directive 2003/54/EC".

[3] Directive2009/73/EC, "Directive2009/73/EC concerning common rules for the internal market in natural gas and repealing Directive 2003/55/EC[8]," 2009.

[4] C. (. 851, "Energy Sector Inquiry,".

[5] . D. W. Caves, L. R. Christensen and W. E. Diewert, "Multilateral comparisons of output, input, and productivity using superlative index numbers," ECONOMIC JOURNAL, vol. 92, pp. 73-86, 1982.

[6] M. Nanere, I. Fraser, A. Quazi and C. D'Souza, "Environmentally adjusted productivity measurement: an Australian case study," J Environ Manage 85(2), pp. 350-362, 2007.

[7] N. K. Minh, P. V. Khanh, N. T. Minh and N. T. P. Anh, "Productivity Growth, technological progress and efficiency change in vietnamese manufacturing industries: a stochastic frontier approach," Open Journal of statistcis, vol. 2, pp. 224-235, 2012.

[8] D. Aiken and C. Pasurka Jr, "Adjusting the Measurement of US Manufacturing Productivity for for Pollution Emissions Control," Resource and Energy Economics 25, pp. 329-351, 2003.

[9] T. Dang and A. Mourougane, "Adjusting Productivity for Pollution in Selected Asian Economies," OECD Green Growth Papers, 2014-01, OECD Publishing, Paris., 2014.

[10] N. Empora and T. Mamuneas, "The Effect of Emissions on U.S. State Total Factor productivity growth,” Review of Economic Analysis 3, pp. 149-172, 2011.

[11] L. Montinari and M. Rochlitz, "Absorptive Capacity Compared: Evidence From Sectoral Data," Applied Econometrics and International Development, Vols. 14-2, 2014.

[12] G. Battese and T. Coelli, "A Model for Technical Efficiency Effects in a Stochastic Frontier Production Function For Panel Data," Empirical Economics, Vols. 20(2),, pp. 325-332, 1995.

[13] J. H. Wang, "Hetersoskedasticity and non monotonic efficiency effects of a sthchastic frontier model," J Prod anal, vol. 18, p. 241:253, 2002.

[14] W. Greene, "Fixed and random effects in stochastic frontier models," J Prod anal, Vols. 732, p. 23, 2005.

[15] I. e. a. Koske, "The 2013 update of the OECD's database on product market regulation: Policy insights for OECD and non-OECD countries," OECD Economics Department Working Papers, No. 1200, OECD Publishing., 2015.

[16] M. O'Mahony and M. P. Timmer, "Output, Input and Productivity Measures at the Industry Level: the EU KLEMS Database,” Economic Journal, vol. 119, no. 538, pp. 374-403, 2009.

[17] F. Belotti, S. Dainone, G. Ilardi and V. Atella, "Stochastic Frontier Analysis using Stata," Stata Journal, 2012.

[18] . S. C. Kumbhakar, G. Lien and J. b. Hardaker, "Technical efficiency in competing panel data models:a study of Norwegian grain farming," J prod Anal, 2012.

[19] EC, "The economic impact of enforcement of competition policies on the functioning of EU energy markets,Specific contract no. COMP/2014/003 implementing Framework Contract ECFIN-005-2011/LOT NO.1," Publications Office of the European Union, ISBN 978-92-79-54567-2, Luxembourg:, 2016. 
Protection (June $27^{\mathrm{TH}}-30^{\mathrm{TH}}, 2017$, Bled, Slovenia), ENERgy MANAGEMENT AND

POLICIES

T. D. Corsatea: The Impact of the European Electricity Market Regulation on Environmental Adjusted Productivity: Evidence from 10 Selected Countries Between 1995 and 2013

[20] G. Nicoletti and S. Scarpetta, "Regulation, Productivity and Growth: OECD Evidence," Economic Policy., vol. 36, pp. 9-72, 2003. 
\begin{tabular}{l|l}
76 & $10^{\mathrm{TH}}$ INTERNATIONAL CONFERENCE ON SUSTAINABLE ENERGY AND ENVIRONMENTAL
\end{tabular}

Protection (June 27 $7^{\mathrm{TH}}-30^{\mathrm{TH}}, 2017$, Bled, Slovenia), EnERgy Management AND

POLICIES 
$10^{\mathrm{TH}}$ InTERnational CONFERENCE ON Sustainable ENERgy AND ENVIRONMENTAL Protection (June $27^{\mathrm{TH}}-30^{\mathrm{TH}}$, 2017, Bled, SLOVENIA), ENERGy MANAGEMENT AND Policies

J. Krope, A.Ghani Olabi, D. Goričanec \& S. Božičnik

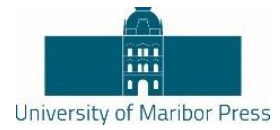

\title{
Energization as a Determinant of Life Quality in the Dispersed Rural Areas in Colombia
}

\author{
ANDRÉS FELIPE LEÓN ESTEBAN, ISAAC GUERRERO RINCÓN, VIATCHESLAV KAFAROV \& \\ ALEXANDRA CORTÉS AGUILAR
}

\begin{abstract}
This paper looks at the effect of energization on income, education, health, and labor productivity in scattered rural areas of Colombia. Our data comes from the National Census of Agriculture, conducted in 2014. To account for endogeneity issues, we estimate a simultaneous system of equations via the three-stage least squares (3SLS) method. We find that a household connected to electricity has a very large and significant effect on health, education and agricultural productivity. We find a little positive but significant effect of electricity on income. The effect of electricity on Income is measured both directly and through the intermediaries of education, health, and agricultural productivity. The highly significant magnitude of electricity's impact on life quality makes a powerful argument for the importance of including energy policies in the development conversation.
\end{abstract}

Keywords: • Dispersed Rural Areas • 3SLS • Energization • Life Quality • Colombia $\bullet$.

CORRESPONDENCE ADDRESS: Andrés F. León, Magister Student, Universidad Industrial de Santander, Economy and Development, Cra $27 \mathrm{Cl}$ 9, Bucaramanga, Colombia, e-mail: leonest17@hotmail.com. Isaac G. Rincón, Mg., Assistant Professor, Universidad Industrial de Santander, Economics and Administration Department, Cra $27 \mathrm{Cl}$ 9, Bucaramanga, Colombia, email: iguerrin@uis.edu.co. Viatcheslav Kafarov, Dr. Sc., Associate Professor, Universidad Industrial de Santander, Chemical Engineering Department, Cra $27 \mathrm{Cl}$ 9, Bucaramanga, Colombia, e-mail: kafarov@uis.edu.co. Alexandra Cortés A., Dr., Associate Professor, Universidad Industrial de Santander, Economics and Administration Department, Cra $27 \mathrm{Cl}$ 9, Bucaramanga, Colombia, e-mail: alexacor@uis.edu.co. 
$10^{\mathrm{TH}}$ INTERNATIONAL CONFERENCE ON SUSTAINABLE ENERGY AND ENVIRONMENTAL Protection (June $27^{\mathrm{TH}}-30^{\mathrm{TH}}, 2017$, Bled, Slovenia), Energy MaNaGement AND POLICIES

A. Felipe León Esteban, I. Guerrero Rincón, V. Kafarov \& A. Cortés Aguilar: Energization as a Determinant of Life Quality in the Dispersed Rural Areas in Colombia

Energization plays a decisive role in the socio-economic and environmental development of any country. A society that has access to electricity creates conditions to alleviate poverty, increase social protection and raise the standard of living. In addition, energy can lead to the mobilization of resources that are paralyzed, creating an array of services that in some cases are precarious [1].

Recently there is a growing interest in the study of energization and its effect life quality. Empirical evidence has demonstrated the relationship of effect and causality between energizing and improving life quality. The most recent research on the subject exposes the risks to health, detriment in education and productivity challenges of those societies that suffer from energy poverty [2-5]. Studies have also highlighted the positive impact of per capita electricity consumption on growth at macro levels [6].

Bridge et al (2016), for example, examine the effect of electricity on income, education, health and labour productivity in Nepal [7]. Their results show that the lack of energy in the territories, has a negative impact on life quality of the habitants. In the particular case of rural communities, it is difficult to develop domestic and agricultural activities, which directly affect the life quality of households. From this perspective, energization is a factor that contributes to improving the levels of education, health, labour productivity and income of families. In other words, energization promotes true sustainable development [8].

This paper follows a similar approach to Bridge et al. (2016). The purpose of the present paper is to analyse the effect of energization as a determinant of quality of life in Colombia. To do this, the National Agricultural Census (CNA in Spanish) [9] of the year 2014 will be used, with which a correlation analysis between the energization and determinants associated to the quality of life is made. Based on the CNA data, it is estimated statistically whether household access to energization is significantly related to health, education, labour productivity and income. Next, the magnitude and meaning of this relationship will be analysed. Due to the possible existence of bidirectional causalities in these relations, the estimation requires an econometric model that represents the endogenous character, which is a model of simultaneous equations of three stages with least squares (3SLS). Subsequently, the different functional relationships are considered taking into account the limitations in the data and the main equation is determined. The present analysis will be carried out using Stata ${ }^{\circledR} 13.0$ software.

\section{$2 \quad$ Modeling Approach}

According to Bridge et al. (2016), the intuitive and anecdotal explanation of the impact of energization is that it improves health, education and productivity at work [8]. In figure 1 , it is observed that there are double-sided arrows, which indicate causality in both directions. It is understandable that an increase in education will lead to an increase in 
income. It is also true that a greater amount of income allows a household to seek better education conditions. Due to these bidirectional causalities, the estimation of the relations will require an econometric model that represents the endogenous character: Model of three-stage simultaneous equations with least squares (3SLS).

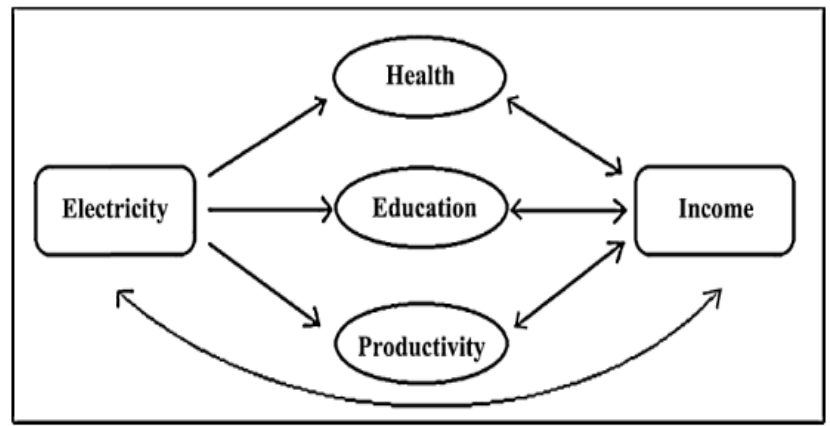

Figure 1. Conceptual model of the interrelationship between electricity and income. Source: Bridge et al. (2016)

\subsection{Functional relationships}

In order to get a true understanding of how the energizing impacts on the life quality of people, you have to start with an understanding of why some homes have electricity while others do not. As stated by Bridge et al. [8], two simple and intuitive indicators are useful for this: (a) only those households that can pay for energizing will have it, and (b) only those families that live in an area where the energization is available will have access to it.

Equation (1) shows household access to energization, which has the function of household wealth and whether it resides within an area with electricity coverage.

$$
\text { Energiza }=f(\text { Wealth }, C)
$$

For a more complete understanding of the differences between households that have and do not have energy, the goal is to analyse households that are the same in every way, different from being energized. The main areas for variation in access to electricity are rural areas, where most households are involved in the agricultural sector. The rest of the analysis will focus only on rural households residing within grid areas. For the purposes of this research, equation (1) becomes:

Energiza $=f($ Wealth $)$ 
A. Felipe León Esteban, I. Guerrero Rincón, V. Kafarov \& A. Cortés Aguilar: Energization as a Determinant of Life Quality in the Dispersed Rural Areas in Colombia

The next step will be to look at the factors that influence the wealth of households. Wealth indicators vary widely by country. For our case, we will use some primary predictors of wealth as they are: income, education, land ownership and health services.

Equations (3) show the wealth of households in terms of education, land tenure and household health services.

Wealth $=f($ Income, Education,

Land_Holding, Health_services)

The substitution of the determinants of wealth (3) in equation (2) gives:

Energiza $=f$ (Income, Education,

Land_holding,Health_services)

As can be seen in Figure 1, the hypothesis is that energization influences household income through the intermediary mechanisms of health, education and productivity. Therefore, we can express the effects of access to energization in the following way:

$$
\text { Health }=f(\text { Energiza, } \bar{X})
$$

$$
\text { Agricul_produc }=f(\text { Energiza }, \bar{X})
$$

\section{Education $=f($ Energiza, $\bar{X})$}

Where $X$ is a vector of household and other commonly accepted characteristics of health, productivity and education. Finally, an understanding of (5)-(7) allows investigating the indirect effects of electricity on income. This is mathematically described as:

$$
\text { Income }=f(\text { Health, Agricult_ } \text { produc, }
$$

\section{Education)}

Limitations in the data are likely to result in limitations on the information obtained from the estimate. For this reason, the direct impact of energization on income was also investigated to take into account the missing information and thus gain a better understanding of the equations (5)-(7). Thus, in practice, the equation (8) will be estimated as: 
$10^{\mathrm{TH}}$ INTERNATIONAL CONFERENCE ON SUSTAINABLE ENERGY AND ENVIRONMENTAL Protection (June $27^{\mathrm{TH}}-30^{\mathrm{TH}}, 2017$, Bled, Slovenia), ENERgy MANAGEMENT AND

POLICIES

A. Felipe León Esteban, I. Guerrero Rincón, V. Kafarov \& A. Cortés Aguilar: Energization as a Determinant of Life Quality in the Dispersed Rural Areas in

Colombia

$$
\begin{aligned}
& \text { Income }=f(\text { Electricity }, \text { Health }, \\
& \text { Agricul_produc,Education })
\end{aligned}
$$

\section{Data Review}

Our data come from the CNA, made by the National Administrative Department of Statistics (DANE in Spanish) in the year 2014. The CNA is the only one of the three censuses carried out in Colombia, which is characterized by being inclusive, it covers 1101 municipalities, the San Andrés Archipelago, Providencia and Santa Catalina, 32 departments, 20 non-municipalized areas, 773 indigenous reserves, 181 afro Colombian communities and 56 national natural parks [9].

The sample size of the cross section of the CNA is 1122 municipalities. Our level of analysis for this study varies according to the available information: households, individuals and Agricultural Productivity Units (UPA in Spanish). This analysis takes into account the entire population concentrated in the dispersed rural areas of Colombia.

The Census provides information about the use and coverage of land, characteristics of UPA's, machinery and infrastructure, population characteristics, education and living conditions, among others. In addition to the information contained in the CNA, proxies related to the Electricity Coverage Index (2014) are added, which represent rural areas different from municipal headings per municipality. Equally, municipal value added is used as a measure of productivity and economic development. The aforementioned variables were obtained from the Colombian Mining and Energy Planning Unit (UPME in Spanish) and the DANE, respectively.

\subsection{Variable list and descriptive statistic}

The descriptive statistics appear in Table 1. For purposes of analysis, we take some decisions about variables of interest: a) except for municipal value added, the rest of the variables used in the model refer to the dispersed rural areas of Colombia, those areas different from the urban centre of the municipalities and the populated centres; $b$ ) with the exception of municipal value added and the total population, the remaining variables used in the model are expressed in percentages. Given that within the national accounts of Colombia the gross domestic product at the municipal level is not estimated, the municipal value added calculated by the National Planning Department (DNP in Spanish) was used. The municipal added value is a proxy variable that is used to express the monetary value of the production of goods and services of final demand, in this particular case, of the municipalities of Colombia.

However, in terms of the main variables, it is assumed that the Municipal Electricity Coverage Index of the dispersed rural areas of Colombia is on average 85\%. In other 
A. Felipe León Esteban, I. Guerrero Rincón, V. Kafarov \& A. Cortés Aguilar: Energization as a Determinant of Life Quality in the Dispersed Rural Areas in Colombia

words, the average energization is relatively high; however, an approximate standard deviation of 0.21 can be observed, which indicates an important inequality gap between municipalities that have energy and those that do not. Something similar occurs with the average percentage of school absenteeism of children between 5 and 16 years of age in rural areas scattered in the municipalities of Colombia; this amounts to approximately $20 \%$; however, it is worrying that in some populations this index reaches figures above $60 \%$. At the same time, the average percentage of harvested areas in the dispersed rural areas of the municipalities of Colombia is $7.35 \%$. Finally, we observe that the average percentage of people without affiliation to the health system in the dispersed rural areas of Colombia is $3.64 \%$. The illiterate ratio, land tenure, sanitary services and livestock head, are considered to support the analysis in this research.

\section{$4 \quad$ Econometric Model}

$$
\begin{aligned}
& \text { Income }=\beta_{0}+\beta_{1} \text { Elect }+\beta_{2} \text { Educa }+ \\
& \beta_{3} \text { Agric } \_ \text {prod }+\beta_{4} \text { Health }+\bar{Y}_{1} \bar{X}_{1}+\varepsilon_{1} \\
& \text { Health }=\delta_{0}+\delta_{1} \text { Elect }+\bar{Y}_{2} \bar{X}_{2}+\varepsilon_{2} \\
& \text { Agric_prod }=\phi_{0}+\phi_{1} \text { Elect }+\bar{Y}_{3} \bar{X}_{3}+\varepsilon_{3} \\
& \text { Educa }=\mu_{0}+\mu_{1} \text { Elect }+\bar{Y}_{4} \bar{X}_{4}+\varepsilon_{4} \\
& \text { Elect }=\rho_{0}+\rho_{1} \text { Income }+\bar{Y}_{5} \bar{X}_{5}+\varepsilon_{5}
\end{aligned}
$$


$10^{\mathrm{TH}}$ INTERNATIONAL CONFERENCE ON SUSTAINABLE ENERGY AND ENVIRONMENTAL 83 Protection (June $27^{\mathrm{TH}}-30^{\mathrm{TH}}, 2017$, Bled, Slovenia), ENERgy MANAGEMENT AND POLICIES A. Felipe León Esteban, I. Guerrero Rincón, V. Kafarov \& A. Cortés Aguilar: Energization as a Determinant of Life Quality in the Dispersed Rural Areas in Colombia

Table 1. Descriptive statistics

\begin{tabular}{|c|c|c|c|c|c|}
\hline Variable & $\begin{array}{l}\text { Ob } \\
\text { s. }\end{array}$ & $\begin{array}{l}\text { Mea } \\
\text { n }\end{array}$ & $\begin{array}{l}\text { Std. } \\
\text { Dev }\end{array}$ & $\begin{array}{l}\text { Mi } \\
\mathbf{n}\end{array}$ & Max \\
\hline Index of electricity coverage (\%) & $\begin{array}{l}11 \\
22\end{array}$ & 0.85 & 0.21 & 0 & 1 \\
\hline $\begin{array}{l}\text { School absenteeism between } 5 \text { - } 16 \text { years old } \\
(\%)\end{array}$ & $\begin{array}{l}11 \\
22\end{array}$ & 19.95 & 6.56 & 0 & 60.24 \\
\hline Harvested area $(\%$, in Hectare $)$ & $\begin{array}{l}11 \\
22\end{array}$ & 7.35 & 11.67 & 0 & 92.87 \\
\hline People without health affiliation (\%) & $\begin{array}{l}11 \\
22\end{array}$ & 3.64 & 3.06 & 0 & 29.63 \\
\hline $\begin{array}{l}\text { Municipal Value Added (thousands of } \\
\text { millions) }\end{array}$ & $\begin{array}{l}11 \\
22\end{array}$ & $\begin{array}{l}618.3 \\
2\end{array}$ & $\begin{array}{l}5478.1 \\
6\end{array}$ & $\begin{array}{l}0.8 \\
5\end{array}$ & $\begin{array}{l}1709 \\
56\end{array}$ \\
\hline Total people & $\begin{array}{l}11 \\
22\end{array}$ & $\begin{array}{l}4569 . \\
3\end{array}$ & $\begin{array}{l}5301.9 \\
2\end{array}$ & 16 & $\begin{array}{l}7073 \\
8\end{array}$ \\
\hline Illiterate rate $(\%)$ & $\begin{array}{l}11 \\
22\end{array}$ & 12.71 & 6.67 & $\begin{array}{l}1.0 \\
9\end{array}$ & 51.56 \\
\hline Own productive units (\%) & $\begin{array}{l}11 \\
22\end{array}$ & 54.26 & 17.92 & 0 & 93.26 \\
\hline Houses with sewer service (\%) & $\begin{array}{l}11 \\
22\end{array}$ & 5.56 & 7.69 & 0 & 93.25 \\
\hline Housing with aqueduct service (\%) & $\begin{array}{l}11 \\
22\end{array}$ & 39.30 & 28.96 & 0 & 100 \\
\hline $\begin{array}{l}\text { People affiliated to the subsidized health } \\
\text { system (\%) }\end{array}$ & $\begin{array}{l}11 \\
22\end{array}$ & 78.64 & 15.84 & $\begin{array}{l}9.5 \\
6\end{array}$ & 98.7 \\
\hline $\begin{array}{l}\text { Agricultural productive units with presence } \\
\text { of livestock }(\%)\end{array}$ & $\begin{array}{l}11 \\
22\end{array}$ & 31.49 & 20.46 & 0 & 92.17 \\
\hline $\begin{array}{l}\text { Households with inappropriate material on } \\
\text { their walls }(\%)\end{array}$ & $\begin{array}{l}11 \\
22\end{array}$ & 4.15 & 6.93 & 0 & 79.79 \\
\hline
\end{tabular}

Source: Authors' calculation using CNA - 2014. 
$84 \quad 10^{\mathrm{TH}}$ INTERNATIONAL CONFERENCE ON SUSTAINABLE ENERGY AND ENVIRONMENTAL Protection (June $27^{\mathrm{TH}}-30^{\mathrm{TH}}, 2017$, Bled, SLOVENiA), ENERGy MANAGEMENT AND POLICIES

A. Felipe León Esteban, I. Guerrero Rincón, V. Kafarov \& A. Cortés Aguilar: Energization as a Determinant of Life Quality in the Dispersed Rural Areas in Colombia

Table 2. 3SLS simultaneous estimation of the impacts of electricity on life quality

\begin{tabular}{|c|c|c|c|c|c|}
\hline & $\begin{array}{l}\text { (1) } \\
\text { Municip } \\
\text { al Value } \\
\text { Added } \\
\text { (log) }\end{array}$ & $\begin{array}{l}(2) \\
\text { People } \\
\text { without } \\
\text { health } \\
\text { affiliatio } \\
\text { n }\end{array}$ & $\begin{array}{l}(3) \\
\text { Harves } \\
\text { ted } \\
\text { area }\end{array}$ & $\begin{array}{l}(4) \\
\text { School } \\
\text { absenteeis } \\
\text { m } \\
\text { between } \\
5-16 \text { years } \\
\text { old }\end{array}$ & $\begin{array}{l}\text { (5) } \\
\text { Index of } \\
\text { electricit } \\
\text { y } \\
\text { coverag } \\
\text { e }\end{array}$ \\
\hline $\begin{array}{l}\text { Index of electricity } \\
\text { coverage }\end{array}$ & $\begin{array}{l}2.558 \\
(0.023) * \\
*\end{array}$ & $\begin{array}{l}-7.459 \\
(0.012)^{*} \\
*\end{array}$ & $\begin{array}{l}8.992 \\
(0.023) \\
* *\end{array}$ & $\begin{array}{l}-9.171 \\
(0.000)^{* *} \\
*\end{array}$ & \\
\hline $\begin{array}{l}\text { School absenteeism } \\
\text { between } 5-16 \text { years } \\
\text { old }\end{array}$ & $\begin{array}{l}-0.335 \\
(0.000)^{*} \\
* *\end{array}$ & & & & \\
\hline Harvested area & $\begin{array}{l}-0.023 \\
(0.011)^{*} \\
*\end{array}$ & & & & \\
\hline $\begin{array}{l}\text { People without health } \\
\text { affiliation }\end{array}$ & $\begin{array}{l}0.453 \\
(0.000)^{*} \\
* *\end{array}$ & & & & \\
\hline $\begin{array}{l}\text { Municipal } \quad \text { Value } \\
\text { Added (log) }\end{array}$ & & & & & $\begin{array}{l}0.029 \\
(0.010)^{*} \\
* *\end{array}$ \\
\hline Total people & $\begin{array}{l}0.000 \\
(0.000)^{*} \\
* *\end{array}$ & $\begin{array}{l}0.000 \\
(0.014) * \\
*\end{array}$ & $\begin{array}{l}0.000 \\
(0.632)\end{array}$ & $\begin{array}{l}-0.000 \\
(0.279)\end{array}$ & $\begin{array}{l}0.000 \\
(0.052)^{*}\end{array}$ \\
\hline Illiterate people & & $\begin{array}{l}0.146 \\
(0.000)^{*} \\
* *\end{array}$ & $\begin{array}{l}-0.196 \\
(0.000) \\
* * *\end{array}$ & $\begin{array}{l}0.175 \\
(0.000)^{* *} \\
*\end{array}$ & $\begin{array}{l}-0.006 \\
(0.000)^{*} \\
* *\end{array}$ \\
\hline Own productive units & $\begin{array}{l}0.011 \\
(0.030)^{*} \\
* *\end{array}$ & $\begin{array}{l}-0.006 \\
(0.215)\end{array}$ & $\begin{array}{l}0.106 \\
(0.000) \\
* * *\end{array}$ & $\begin{array}{l}0.184 \\
(0.083) *\end{array}$ & $\begin{array}{l}-0.000 \\
(0.931)\end{array}$ \\
\hline $\begin{array}{l}\text { Houses with sewer } \\
\text { service }\end{array}$ & & $\begin{array}{l}0.011 \\
(0.179)\end{array}$ & & & \\
\hline $\begin{array}{l}\text { Housing } \\
\text { aqueduct service }\end{array}$ & & $\begin{array}{l}-0.002 \\
(0.788)\end{array}$ & & & \\
\hline $\begin{array}{l}\text { People affiliated to the } \\
\text { subsidized health } \\
\text { system }\end{array}$ & & $\begin{array}{l}-0.075 \\
(0.000)\end{array}$ & & & \\
\hline $\begin{array}{l}\text { Agricultural } \\
\text { productive units with } \\
\text { presence of livestock }\end{array}$ & & & $\begin{array}{l}-0.205 \\
(0.000) \\
* * *\end{array}$ & & \\
\hline
\end{tabular}


$10^{\mathrm{TH}}$ INTERNATIONAL CONFERENCE ON SUSTAINABLE ENERGY AND ENVIRONMENTAL

POLICIES

A. Felipe León Esteban, I. Guerrero Rincón, V. Kafarov \& A. Cortés Aguilar: Energization as a Determinant of Life Quality in the Dispersed Rural Areas in

Colombia

\begin{tabular}{|l|l|l|l|l|l|}
\hline $\begin{array}{l}\text { Households with } \\
\text { inappropriate } \\
\text { material on their walls }\end{array}$ & & & & & $\begin{array}{l}-0.003 \\
(0.003)^{*} \\
* *\end{array}$ \\
\hline _cons & $\begin{array}{l}6.910 \\
(0.000)^{*} \\
\end{array}$ & $\begin{array}{l}14.233 \\
(0.000)^{*} \\
* *\end{array}$ & $\begin{array}{l}2.777 \\
(0.503)\end{array}$ & $\begin{array}{l}24.728 \\
(0.000)^{* *}\end{array}$ & $\begin{array}{l}0.812 \\
(0.000)^{*} \\
* *\end{array}$ \\
\hline No. of Obs. & 1122 & 1122 & 1122 & 1122 & 1122 \\
\hline Chi-Square & 181.27 & 406.15 & 236.16 & 100.04 & 89.47 \\
\hline P-value & 0.000 & 0.000 & 0.000 & 0.000 & 0.000 \\
\hline
\end{tabular}

Source: Authors' calculation using (NCA 2014)

$* \mathrm{P}<.10$. ** $\mathrm{P}<.05$. *** $\mathrm{P}<.01 . \mathrm{P}$ Value in parenthesis

\section{$5 \quad$ Results}

Our regression results show that there is a positive impact of access to electricity on the municipal value added. This effect is observed both directly through the intermediate effects of levels of education, health and agricultural productivity. Table 2 presents the results of the regression of the equations (10) to (14), where at the same time the determinants of five different variables of interest are estimated.

In the proposed functional relations, it was hypothesized that the constant supply of electrical energy is related to positive way, with the best levels of education, health, productivity and income of the households that are located in the Dispersed Rural Areas in Colombia. The results obtained are highly significant and with expected signs of the relationship. This hypothesis is corroborated by the results of our 3SLS estimate.

We see in model (5) that an increase in the municipal value added, ceteris paribus, entails a rise on the electric coverage index in the dispersed rural areas of the municipalities' is positive. Nevertheless, despite the level of meaning, the effect is not of the magnitude expected. This can be explained mainly by two reasons: the first has to do with the type of variable (proxy) that is the value added and the second is related to the centralized policies of energization in Colombia, that is to say to a great extent that a municipality is energized or not, it depends on the policies centralized from the Government.

Now you can see the direct impact of energy on life quality indicators. Model (4) in Table 2 shows that the electric coverage index has a positive and very significant effect on the schooling attendance of children from 5 to 16 . This means that before an increase by one percentage point of the electric energy coverage index, Ceteris paribus, the percentage of school absenteeism among children between the ages of 5 and 16 decreases approximately $9.2 \%$. In other words, an area that has more energization, generates a considerable decrease in school attendance. This result provides a quantitative understanding of the anecdotal discussion about the benefits of electricity over education. 
$10^{\mathrm{TH}}$ INTERNATIONAL CONFERENCE ON SUSTAINABLE ENERGY AND ENVIRONMENTAL Protection (June $27^{\mathrm{TH}}-30^{\mathrm{TH}}, 2017$, Bled, Slovenia), Energy Management AND POLICIES

A. Felipe León Esteban, I. Guerrero Rincón, V. Kafarov \& A. Cortés Aguilar: Energization as a Determinant of Life Quality in the Dispersed Rural Areas in Colombia

Our next indicator of development is agricultural productivity. In model (3) of Table 2 we again observe the anecdotal evidence of the importance of electricity over agricultural productivity. An example is the electric water pumps, which make irrigation much easier, thus favouring fertilization techniques. Similarly, access to power tools reduces the labour intensity of agricultural laboratories. From Table 2, it can be deduced that the rate of electric energy coverage increases by one percentage point, ceteris paribus, the percentage of cultivated area would increase by approximately 9 percentage points. This result is reasonable if we consider that an energized farm makes the most of irrigation systems, fertilization and pesticide techniques. Important is also the effect of the presence of cattle in dispersed rural areas. According to the model, a 10\% increase in livestock in productive and non-productive units, ceteris paribus, will lead to a reduction of 2 percentage points in the total area harvested.

The variable used to investigate health outcomes in model (2) of Table 2 shows some interesting results. Due to the limitations in the data, the variable used as determinant of health are the people without affiliation to health. This variable gives us an indication of the number of people who do not have a health service in the dispersed rural areas of the municipalities of Colombia. Again, we find a significant effect of energization on health service affiliation. The above could be explained from the following perspective: "the provision of the health service is affected in the populations that have a lower coverage of electrical energy". The results in table 2 indicate that, if the electric coverage index increases by $1 \%$, ceteris paribus, the percentage of people without health system affiliation will decrease by approximately 7.5 percentage points. Likewise, it is important to highlight the effect of illiteracy on people without health affiliation. The model indicates that a $10 \%$ increase in the percentage of illiterate people in a municipality, ceteris paribus, would cause an increase of 1.5 percentage points in the percentage of people without health affiliation.

The model (1) in Table 2 brings together all the information of the models (2)-(5) to estimate the total impact of electricity on life quality. The first important result is that the three indicators of development (education, productivity and health) have the expected signs and are significant at a level of $1 \%$. An increase in the electric coverage index by one percentage point, ceteris paribus, will cause municipal value added to increase by $2.56 \%$. Likewise, if the percentage of people without health system affiliation increases by $1 \%$, ceteris paribus, the municipal value added will increase by $0.45 \%$. Regarding education and productivity we have found some counterintuitive results: if the Percentage of school absence among young people aged 5 to 16 increases by one percentage point, ceteris paribus, the municipal value added will decrease by $0.3 \%$. If the percentage of cultivated area increases by $1 \%$, ceteris paribus, the municipal value added decreases by $0.02 \%$. Although it was assumed that education and productivity had a positive effect on income, we observed that the effect was slightly contrary. This can be explained by the nature of the variable used to measure income. 
$10^{\mathrm{TH}}$ INTERNATIONAL CONFERENCE ON SUSTAINABLE ENERGY AND ENVIRONMENTAL

A. Felipe León Esteban, I. Guerrero Rincón, V. Kafarov \& A. Cortés Aguilar: Energization as a Determinant of Life Quality in the Dispersed Rural Areas in

Colombia

\section{Conclusion}

Using a 3SLS approach that control for endogeneity problems, this study finds that municipal value added is determined in part by the Electric Energy Coverage Index. We also find that levels of education, health and agricultural productivity are largely determined by access to electricity, both directly and through the intermediate impacts of each variable. The magnitude and high significance of the impact of electricity on life quality of people in dispersed rural areas creates a powerful argument in favour of the importance of including energy in local development.

\section{Acknowledgements}

The authors of this research would like to thank The Research Group on Regional Development and Spatial Planning (GIDROT in Spanish) and the Research Center for Sustainable Development (CIDES in Spanish), the Industrial University of Santander (UIS in Spanish), the department of Economics and Administration UIS.

\section{References}

[1] A. Gaye, «Access to Energy and Human Development,» de Human Development Report 2007/2008, 2007.

[2] F. Birol, «Energy Economics: a place for energy poverty in the agenda?,» Energy Journal, pp. 1-6, 2007.

[3] B. K. Sovacool, «The political eoconomy of energy poverty: A review of the key challenges,» Energy for Sustainable Development, pp. 272-282, 2012.

[4] D. Sagar, «Alleviating energy poverty for the world's poor,» Energy Policy, pp. 1367-1372, 2005.

[5] A. K. Reddy, «Goals, strategies and for rural energy,» Economic and Political Weekly, pp. 3435-3445, 1999.

[6] M. Shahbaz, S. Khan y M. I. Tahir, «The dynamic links between energy consumption, economic growth, financial development and trade in China: Fresh evidence from multivariate framework analisys,» Energy Economics, pp. 8-21, 2013.

[7] S. R. Khandker, D. F. Barnes y H. A. Samad, «Welfare impacts of rural electrification: A panel data analisys from vietnam,» Economic Development and Cultural Change, pp. 659692, 2013.

[8] A. B. Bridge, D. Adhikari y M. Fontela, «Electricity,,» The Social Science Journal, vol. I, no 53, pp. 33-39, 2016.

[9] DANE, «National Agricultural Census,» Departamento Administrativo Nacional de Estadística, Bogotá, 2014. 
88 10 $10^{\mathrm{TH}}$ INTERNATIONAL CONFERENCE ON SUSTAINABLE ENERGY AND ENVIRONMENTAL

Protection (June 27 $7^{\mathrm{TH}}-30^{\mathrm{TH}}, 2017$, Bled, Slovenia), EnERgy Management AND

POLICIES 
$10^{\mathrm{TH}}$ InTERnational CONFERENCE ON Sustainable ENERgy AND Environmental Protection (June 27 $7^{\mathrm{TH}}-30^{\mathrm{TH}}, 2017$, BLed, SLOVENIA), ENERGy MANAGEMENT AND Policies

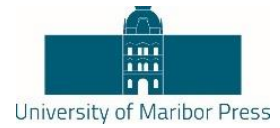

\title{
Impact of Dynamic Pricing Mechanism on Net Metered Consumers in India
}

\author{
JAGRUTI THAKUR \& BASAB CHAKRABORTY
}

\begin{abstract}
The modernization of grid and increased renewable penetration had led to a requirement of alternative tariff mechanisms for consumers. The increasing PV deployment trend as well as implementation of smart meters under smart grid pilot projects in India has opened up avenues for time based retail rates and net metering policies for residential consumers. In this paper, unit commitment based energy system model is used to simulate hourly wholesale electricity prices for the present energy mix. Based on modelled wholesale electricity prices, various retail rates are designed using standard retail rate design principles. The electricity bills of 97 residential consumers are calculated under two different scenarios (net metering with rollover and net metering with Feed in tariff). The results indicate that under different retail rates, the savings of net metered consumers vary. Retail rates are linked to consumer economics and hence would be critical in deciding future PV deployment trends.
\end{abstract}

Keywords: • Net metering $\bullet$ retail rate modelling $\bullet$ India $\bullet$ energy system model $\bullet$ energy policy $\bullet$.

CORRESPONDENCE ADDRESS: Jagruti Thakur, Research Scholar, Indian Institute of Technology, Rajendra Mishra School of Engineering Entrepreneurship Assistant, Kharagpur 721302, India, jagruti.t@iitkgp.ac.in. Basab Chakraborty, Ph.D, Assistant Professor, Indian Institute of Technology, Rajendra Mishra School of Engineering Entrepreneurship, Kharagpur 721302, India; email: basab@see.iitkgp.ernet.in. 
$10^{\mathrm{TH}}$ INTERNATIONAL CONFERENCE ON SUSTAINABLE ENERGY AND ENVIRONMENTAL Protection (June $27^{\mathrm{TH}}-30^{\mathrm{TH}}, 2017$, Bled, Slovenia), Energy Management AND POLICIES

J. Thakur \& B. Chakraborty: Impact of Dynamic Pricing Mechanism on Net Metered Consumers in India

The growth of solar PV in residential sector had led to developments in regulations and policies for grid integrated solar photovoltaic (PV). Under National solar mission, one of the initiative of National Action Plan on Climate Change, the government of India (GOI) has set up an ambitious target of installing $100 \mathrm{GW}$ solar by 2022. Out of this $100 \mathrm{GW}$, solar capacity of $40 \mathrm{GW}$ is supposed to be achieved through rooftop PV. There are two ways in which rooftop solar PV is often compensated; gross metering and net metering. In net metering, the consumers are compensated based on prevailing retail rates and in gross metering a fixed amount is paid for excess generation (PV generation is more than consumption). The net metering policies are being devised in various states in India. State electricity regulatory committees have designed state specific net metering policies by defining, size of solar panel, compensation for excessive units generated and other parameters [1]

Usually, while calculating consumer economics of PV, retails rates are assumed to be increasing or constant [2]. The paper investigates the impact of various retail rates on electricity bills of net metered consumers. In literature, there are studies which analyse the impact of renewable penetration on wholesale electricity rates [3], [4]. Also, the impact of retail rates on behind the meter PV generation is studied [5], [6]. The literature to link wholesale electricity rates with retail rates and study of impact on net metered consumers is sparse. Darghouth et al [7] and Darghouth [8], study various aspect of net metering, retail rates and electricity market. In a study, Darghouth et al studies uncertainty in future value of bill savings for three different factors: changes in PV compensation mechanism, changes in electricity market conditions and changes in retail rates for residential PV consumers [2].

In this analysis, wholesale prices are simulated using an energy systems model in which energy only market is considered. The modelled wholesale rate is used to design retail rates and calculate annual bills of net metered consumers. The analysis is first of its kind in India to understand the consumer economics of PV based on wholesale electricity rates. The analysis is based on underlying assumptions which may influence the results. The scenarios designed for the analysis consider the prevailing guidelines for net metering existing in different states in India. The results of the study would aid in policy design and add towards literature for supporting renewables and smart tariff mechanisms in India.

\section{Data, Methodology and Assumptions}

The state of Karnataka, in the southern part of India is considered for the present study. The data of 97 residential consumers from a smart grid pilot project is utilized for the purpose of bill calculation. The solar PV generation is simulated from PVWatts India for the location considered in the analysis [9]. The average residential consumption load profile indicates two peaks, one in morning and another in evening [10]. Also, there are 
J. Thakur \& B. Chakraborty: Impact of Dynamic Pricing Mechanism on Net Metered

a few consumers with distinct consumption patterns having variance in peak consumption as compared to the usual morning and evening peaks [10]. The load pattern of a consumer is of huge importance while calculating bills based on time variant retail rates.

The size of solar panel is calculated based on $90 \%$ of energy consumption of the consumer as per guidelines provided by State Electricity Regulatory Commission (SERC) [11]. The electricity bills of consumers is calculated after hourly netting with PV for each retail type in both the scenarios.

The wholesale electricity prices are modelled using a unit commitment model based on mixed energy linear programming optimisation. The wholesale market design is discussed in detail in section 2.1. Retail rates are modelled using simulated wholesale electricity rates as discussed in section 2.2. The net consumption of consumer is calculated using simulated solar generation data. The bills of these net metered consumers are calculated using designed retail rates.

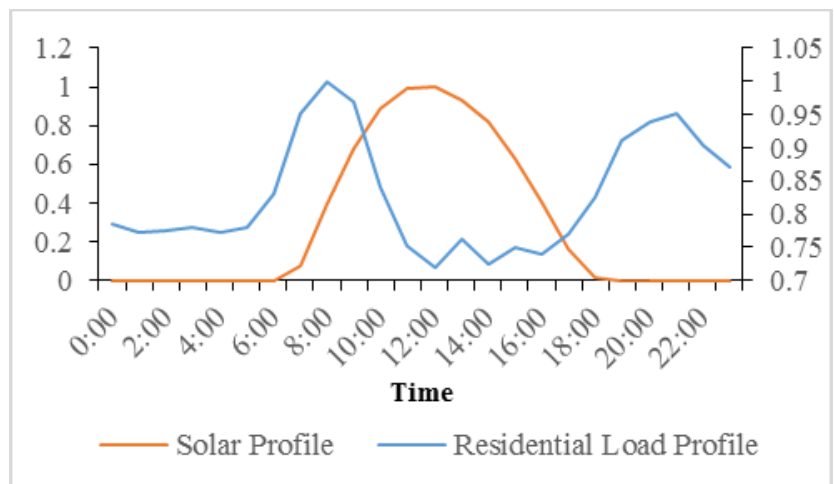

Figure 1: Normalized annual average load profile of residential consumers and normalized annual solar generation profile

Figure 1 exhibits the normalized annual average load profile of a residential consumer vis-a-vis solar generation profile. It is observed that the peak of PV generation coincides with low consumption of a consumer. This coincidence impacts the bill savings achieved through PV in time varying retail rates. The peaks of generation and consumption are of huge importance for consumer economics in time variant rates.

\subsection{Wholesale market design}

In the first step, wholesale electricity prices are modelled with an energy system model. The optimization of the model is based on a mixed integer programming, thereby minimizing the overall marginal cost of the electricity. The present energy mix is considered for the analysis. The hourly load profile of 2015 of the state is considered for simulation of energy system. The details of power plant like number 
POLICIES

J. Thakur \& B. Chakraborty: Impact of Dynamic Pricing Mechanism on Net Metered Consumers in India

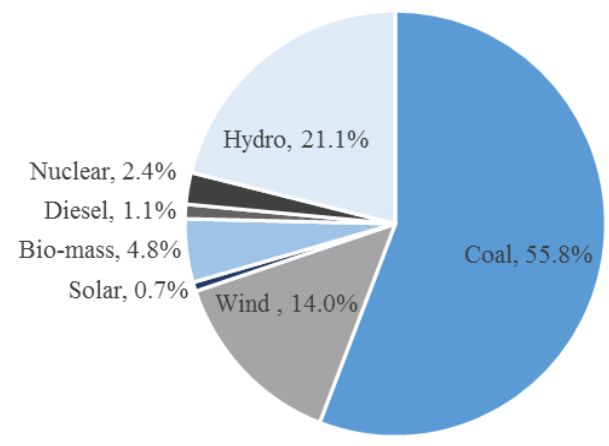

Figure 2. Energy Mix of Karnataka

of blocks, efficiency of power plants and availability of power plants is also considered. The marginal fuel cost of various fuels is included for the analysis. The generation profile of solar and wind is used as input for the model.

It is observed from figure 2 that solar is less than $1 \%$ of total energy mix [12] and hence there are policies from state government to encourage integration of solar in the grid.

As energy only market design is used, the marginal cost of generation of most expensive plant sets the cost for that particular hour and assists other plants in recovering their fixed costs. The model is designed to meet the supply demand with minimum marginal cost.

\subsection{Retail rate design}

Retail rates are designed using standard design rate principles with the simulated wholesale prices. There are two components of retail rate: fixed charge per month and variable costs. Fixed charge is same for all the months, for all the retail rates and variable charges depend on the amount of units consumed. While designing retail rates, the criteria of meeting the revenue of utility by residential consumers is taken into account. There are four different retail rates considered for the analysis; inclining block rate, time of use rate, critical Peak price rate and real time price rate.

Inclining block rate (IBR) is non dynamic rate design. It does not depend on the time of consumption. This rate is not designed using wholesale price. IBR specified in the tariff schedule of Karnataka for the year 2015-16 is considered for the present analysis [13]. In India, IBR is the most prevalent tariff rate for residential consumers. Time of use (TOU) rate is a dynamic pricing mechanism based on the hour of the day. Time of use rate is designed using simulated wholesale prices. Based on threshold value, 3 time periods are designed with no period lesser than 3 hours. Off peak, mid-peak and peak are 
$10^{\mathrm{TH}}$ INTERNATIONAL CONFERENCE ON SUSTAINABLE ENERGY AND ENVIRONMENTAL 93 Protection (June $27^{\mathrm{TH}}-30^{\mathrm{TH}}, 2017$, Bled, Slovenia), ENERgy MANAGEMENT AND POLICIES

J. Thakur \& B. Chakraborty: Impact of Dynamic Pricing Mechanism on Net Metered Consumers in India

three periods, with lowest tariff rate in off peak period and highest tariff rate in peak period.

Critical peak price (CPP) rate is a variant of TOU rate. Based on simulated wholesale price, 15 highest price days are considered as critical peak days in a year. The critical peak period can be for 8 hour maximum in a day. The tariff for all the other days except for critical days is same as TOU rate. On critical peak days, the tariff for critical peak hour is twice than that of normal peak price.

In real time pricing (RTP), the consumers are charged based on hourly wholesale rate. The wholesale rates are not enough to recover the revenue; hence an adder is aggregated to wholesale prices which is calculated based on the difference between required revenue and revenue earned from variable charges.

\subsection{Bill calculation}

The hourly consumption of consumers is offset by hourly PV generation. The regulations of net metering are considered while designing the size of the solar PV. The monthly bills of net metered consumers are calculated for the four different retail rates. In IBR, the bills are calculated based on increase in consumed units. In case of TOU and CPP, the consumption in a period is aggregated for the month and multiplied by TOU rate. For RTP rate, the hourly consumption is multiplied with the corresponding hourly retail rate plus a volumetric adder.

The bills are calculated for two different scenarios. In the first scenario (Scenario 1), if the exported units are more than imported units, they are settled in next month's bill (that is, monthly rollover is considered). For TOU and CPP, the excessive units in an hour at the end of the month are adjusted in the same hour in the next month. In RTP, the excessive units are carried forward on the next day in the same hour. Any remaining units at the end of the year are forfeited.

In scenario 2, instead of rollover, the excessive units are compensated based on feed in tariff (FiT) decided by the SERC. In this case, we have assumed Rs. 6.03 per unit [14]. In all the cases, the compensation is monthly. Table 1 enumerates comparison between the two scenarios. 
$10^{\mathrm{TH}}$ INTERNATIONAL CONFERENCE ON SUSTAINABLE ENERGY AND ENVIRONMENTAL Protection (June 27 $7^{\mathrm{TH}}-30^{\mathrm{TH}}, 2017$, Bled, Slovenia), EnERgy Management AND POLICIES

J. Thakur \& B. Chakraborty: Impact of Dynamic Pricing Mechanism on Net Metered Consumers in India

Table 1: Comparison between scenario 1 and scenario 2

\begin{tabular}{|c|c|}
\hline Scenario 1 & Scenario 2 \\
\hline $\begin{array}{l}\text { Monthly/ Daily rollover } \\
\text { of excessive units }\end{array}$ & No rollover of excessive units \\
\hline $\begin{array}{l}\text { No monthly } \\
\text { compensation }\end{array}$ & $\begin{array}{l}\text { Monthly compensation for } \\
\text { excessive units, based on feed } \\
\text { in tariff of Rs. } 6.03 / \mathrm{kWh}\end{array}$ \\
\hline $\begin{array}{l}\text { Waived off excessive } \\
\text { units at the end of the } \\
\text { settlement period (a year) }\end{array}$ & $\begin{array}{l}\text { Settlement is done on monthly } \\
\text { basis }\end{array}$ \\
\hline $\begin{array}{l}\text { Fixed monthly cost Rs. } \\
25\end{array}$ & Fixed monthly cost Rs. 25 \\
\hline \multicolumn{2}{|r|}{ IBR } \\
\hline $\begin{array}{l}\text { Monthly rollover. Bill } \\
\text { based on net } \\
\text { consumption in a month. }\end{array}$ & $\begin{array}{l}\text { Monthly settlement based on } \\
\text { FiT. }\end{array}$ \\
\hline \multicolumn{2}{|c|}{ TOU and CPP } \\
\hline $\begin{array}{l}\text { Monthly rollover but } \\
\text { excess units are carried } \\
\text { forward to the same hour } \\
\text { of the next month }\end{array}$ & $\begin{array}{l}\text { Monthly compensation based } \\
\text { on fixed FiT in case of excess } \\
\text { generation, regardless of hour } \\
\text { of generation. }\end{array}$ \\
\hline \multicolumn{2}{|r|}{ RTP } \\
\hline $\begin{array}{l}\text { Daily rollover. Excess } \\
\text { units are forfeited at the } \\
\text { end of the year }\end{array}$ & $\begin{array}{l}\text { Compensation is provided } \\
\text { based on hourly excess } \\
\text { generation. The FiT remains } \\
\text { same irrespective of time of } \\
\text { generation }\end{array}$ \\
\hline
\end{tabular}

\section{$3 \quad$ Results}

The inclining block rate is based on tariff rate of urban residential consumers in Karnataka. There are 4 blocks in IBR, in which the price increases in subsequent blocks with increase in consumption of electricity. Based on a threshold value of wholesale prices three time periods are designed. The off peak periods are from 01:00 to 07:00 hours and 22:00 to 00:00 hours, mid peak is from 13:00 hours to 18:00 hour and peak periods from 07:00 to 13:00 hours and 18:00 to 22:00 hours.

CPP is designed based on maximum priced 15 days in a year. Those 15 days will be considered critical peak days and during rest of the days normal TOU rate is applied. CPP days will have twice the peak prices during critical peak hours. 
$10^{\mathrm{TH}}$ INTERNATIONAL CONFERENCE ON SUSTAINABLE ENERGY AND ENVIRONMENTAL

J. Thakur \& B. Chakraborty: Impact of Dynamic Pricing Mechanism on Net Metered Consumers in India
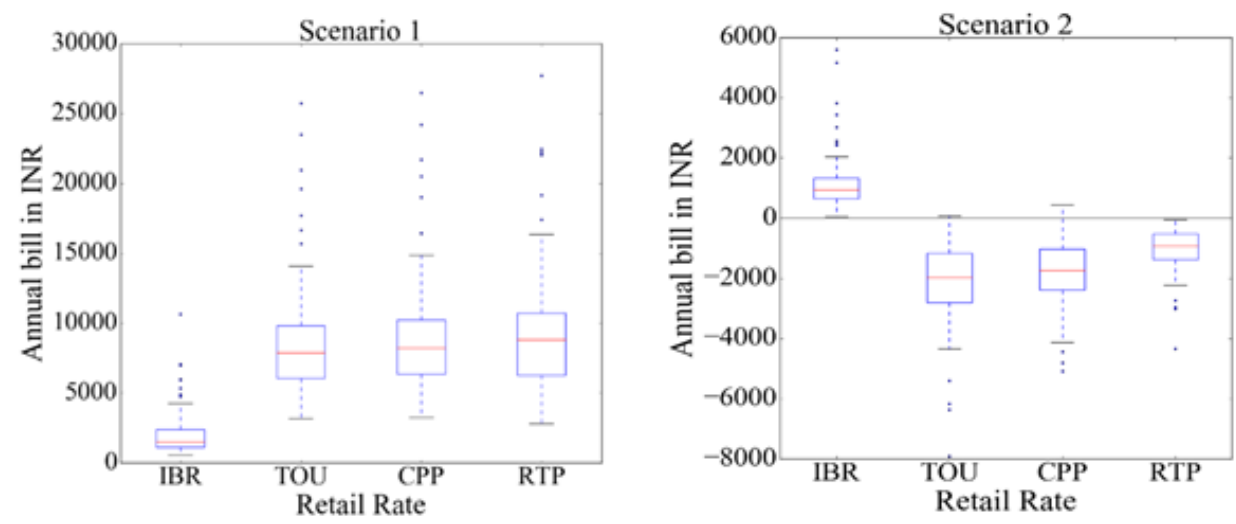

Figure 3. Annual bill in scenario 1 and scenario 2

In RTP, hourly simulated wholesale prices with an adder is multiplied directly with hourly consumption of a consumer, for calculating bills of a consumer.

Based on the designed retail rates, annual bill of net metered consumer is calculated. Figure 3 plots the annual bills of net metered consumers under different retail rate mechanisms. It is observed that, on an average, the annual bill is the least in IBR as compared to other dynamic pricing mechanism, with maximum bill being realized in RTP. The peak period of consumption is 07:00 to 10:00 hours and 19:00 to 21:00 hours whereas the peak of PV generation is 11:00 to 13:00 hours. The peaks of consumption and generation do not coincide, hence when the excessive units are carried forward to same hour, it belongs to off peak period in time varying rates. The retail rate for off peak period is the lowest, leading to lower compensation. This can be observed in figure 3 . Hence in TOU, CPP and RTP, which is based on the hour of consumption, the compensation is less for net metered consumers. The time variant rates are beneficial to utility as they assist in peak load management. But, as observed in scenario 1, IBR proves to be the most beneficial to net metered consumers. TOU is more beneficial than RTP because TOU and CPP get the advantage of increased PV compensation due to averaging of wholesale prices in peak periods.

In scenario 2, reverse trend as compared to scenario 1 is observed. The feed in tariff is more than average retail rate (Rs. $4.8 / \mathrm{kWh}$ ) in this case, and monthly compensation is provided as opposed to monthly rollover as in scenario 1 . Hence, the annual bill is bound to decrease. The bill in IBR is maximum in this case with minimum in TOU rate. In time varying rates, maximum PV generation is during time period when the consumption is low, hence the accumulated units are more during off peak period at the end of the month. As the compensation is fixed irrespective of time of generation, hence the compensation achieved is quite high and annual bill is decreased. 
$10^{\mathrm{TH}}$ INTERNATIONAL CONFERENCE ON SUSTAINABLE ENERGY AND ENVIRONMENTAL Protection (June 27 $7^{\mathrm{TH}}-30^{\mathrm{TH}}, 2017$, Bled, Slovenia), ENERgy MANAGEMENT AND POLICIES

J. Thakur \& B. Chakraborty: Impact of Dynamic Pricing Mechanism on Net Metered Consumers in India

Since IBR is prevalent among the domestic consumers in India, the present analysis is futuristic. Time based rates exist for industrial consumers in India [10]. However, with increased impetus to smart grid and increased installation of smart meters by the government as well as private utilities, the possibility of introduction of alternative smart tariff rates (time varying rates) for domestic consumers is increasing.

In scenario 1, IBR which is a non-time differentiated rate proves to be most beneficial. Traditionally, it is considered that IBR does not send appropriate price signals to consumers regarding peak hours. In scenario 2 , it is observed that consumers with TOU achieve maximum benefits whereas, they pay maximum bill in case of IBR. In IBR, bills do not vary, as there is no time varying element, where as in TOU, CPP and RTP annual bill depends on the load profile of the consumer along with the proportion of PV generation during high priced periods.

The annual bills are lesser for consumers in non-time variant rates when net metering is compensated based on retail rate and with the introduction of net metering with feed in tariffs, time variant rates prove to be more useful. In scenario 1, the excessive units are zeroed out at the end of the year, which reduces the average compensation per Kwh generated. In net metering with feed in tariff, the compensation is more than average retail rate, hence the time variant rates prove to be more beneficial. The PV generation during off peak period keeps accumulating as it is more than the consumption of a consumer most of the times, owing to the load profile. These units cannot be used for hourly netting during other time periods due to the inherent feature of retail rate. Hence, the compensation is more in scenario 2 .

The net metering scheme of scenario 1 is more beneficial economically to utilities for their financial viability. The increased installation of smart meters would open up avenues for time varying retail rates. But as observed in scenario 1, it discourages consumers from $\mathrm{PV}$ deployment due to less savings in annual bills as compared to time invariant varying rates. The average compensation per unit is less as it is based on prevalent retail rates. With higher feed in tariff compared to average retail rate, dynamic retail rates prove to be a good option. This would serve the two-fold benefit of accepting time based rates and also increased PV installation. In contrast, this would increase cross subsidy and also burden viability gap funding of the government further. The distribution companies in India are already financially sick and designing polices of this kind would further worsen the situation. There is an increasing trend in gap between average cost of supply and average realized revenue, which have worsen the financial stability of utilities [15]. This also led to opposition from some utilities while forming a net metering with feed in tariff policy. PV deployment trend depends directly on the financial benefits derived from it.

In scenario 1, based on retail rate, non-time variant rates might lead to increased PV deployment but would deprive utility from achieving benefits of time based rates. In 
$10^{\mathrm{TH}}$ INTERNATIONAL CONFERENCE ON SUSTAINABLE ENERGY AND ENVIRONMENTAL 97 Protection (June $27^{\mathrm{TH}}-30^{\mathrm{TH}}, 2017$, Bled, Slovenia), ENERgy MANAGEMENT AND POLICIES

J. Thakur \& B. Chakraborty: Impact of Dynamic Pricing Mechanism on Net Metered Consumers in India

scenario 2 time based rates would prove to be more useful but would prove financially infeasible to the utility. Hence, the design of policy is critical for benefits to consumers without losses to utility. Increased deployment of PV would help government achieve $40 \mathrm{GW}$ target of rooftop solar PV. This would also assist in reduction of CO2 emissions along with economic benefits and advancing nation towards achievement of climate change goals.

In future, retail rate mechanism would play a definite role in manoeuvring PV deployment trend with regards to impact on consumer economics. The suitability of gross or net metering is a debatable issue for the government and utilities. The introduction of time based rates will further lead to revision of policies to be suitable for PV adoption.

The impact of increased solar penetration on retail rates will further impact the PV deployment trend, as it may shift the peak periods and hence change time varying rates drastically. This will further impact the compensation to net metered consumers and hence affect the PV deployment trend in future. Also, the components of tariff like demand charge, fixed charge or minimum charge will play a significant role in the bill savings from solar PV.

\section{Conclusion}

In the research, it is observed that net metering leads to saving in electricity bills for the consumers. Based on the policy of the state, the impact of different retail rates affect the savings of the consumers. In absence of any feed in tariff for the consumer, rates which do not vary with time proved to be more beneficial. This would encourage PV deployment for consumers with flat rate or IBR and hence discourage implementation of time varying rates which send proper price signals to the consumers. On the other hand, net metering with feed in tariff, leads to increased savings to consumers with time varying rates, but it also poses a question about financial viability of a utility. This mechanism encourages PV deployment but also causes burden on government and utilities. Hence, retail rate design would prove to be critical in future PV deployment trend, due to its direct linkage with savings realized from PV.

\section{References}

[1] Combined summary of CERC \& SERCS regulations/tariff orders, Ministry of new and renewable energy source, Government of India.

[2] N. R. Darghouth, G. Barbose, and R. H. Wiser, "Customer-economics of residential photovoltaic systems (Part 1): The impact of high renewable energy penetrations on electricity bill savings with net metering," Energy Policy, vol. 67, pp. 290-300, Apr. 2014.

[3] S. Weissman and N. Johnson, "The State-wide Benefits of Net-Metering In California," 2012

[4] A. D. Mills and R. H. Wiser, "Changes in the economic value of photovoltaic generation at high penetration levels: A pilot case study of California," in 2012 IEEE 38th Photovoltaic Specialists Conference (PVSC) PART 2, 2012, pp. 1-9. 

Protection (June $27^{\mathrm{TH}}-30^{\mathrm{TH}}, 2017$, Bled, Slovenia), Energy Management AND POLICIES

J. Thakur \& B. Chakraborty: Impact of Dynamic Pricing Mechanism on Net Metered Consumers in India

[5] N. R. Darghouth, G. Barbose, and R. Wiser, "The impact of rate design and net metering on the bill savings from distributed PV for residential customers in California," Energy Policy, vol. 39, no. 9, pp. 5243-5253, Sep. 2011.

[6] A. Mills, R. Wiser, G. Barbose, and W. Golove, "The impact of retail rate structures on the economics of commercial photovoltaic systems in California," Energy Policy, vol. 36, no. 9, pp. 3266-3277, Sep. 2008.

[7] N. Darghouth, "Electricity Bill Savings from Residential Photovoltaic Systems: Sensitivities to Changes in Future Electricity Market Conditions," eScholarship, Apr. 2014.

[8] N. R. Darghouth, "Uncertainties in the Value of Bill Savings from Behind-the-Meter, Residential Photovoltaic Systems: The Roles of Electricity Market Conditions, Retail Rate Design, and Net Metering," eScholarship, Jan. 2013.

[9] NREL, Renewable Resource Data Center: PVWatts. National Renewable Energy Laboratory. [Online]. Available: http://pvwatts.nrel.gov/india/. [Accessed: 09-Apr-2017].

[10] J. Thakur and B. Chakraborty, "Demand side management in developing nations: A mitigating tool for energy imbalance and peak load management," Energy, vol. 114, pp. 895-912, Nov. 2016.

[11] Guidelines for Grid-connected Small Scale (Rooftop) Solar PV Systems for Tamil Nadu, Tamil Nadu Energy Development Agency (TEDA).

[12] Central Electricity authority. Ministry of Power. Government of India. (March, 2016). All India installed capacity (in MW) of power stations. [Online]. Available: http://www.cea.nic.in/reports/monthly/installedcapacity/2016/installed_capacity-03.pdf.

[13] Tariff order for FY 2016, Karnataka Electricity Regulatory Commission, [Online] Available: $\quad$ http://www.karnataka.gov.in/kerc/Pages/Tariff-Orders.aspxBESCOMTARIFF-2015-16.pdf. [Accessed: 09-Apr-2017].

[14] Tariff Order for Solar Rooftop and small Photovoltaic Power Plants FY17-FY18, Karnataka Electricity Regulatory Commission.

[15] Report on "The Performance of State Power Utilities for the years 2012-13 to 2014-15" Power Finance Corporation Ltd., Government of India. 
$10^{\mathrm{TH}}$ InTERnational CONFERENCE ON Sustainable ENERgy AND ENVIRONMENTAL Protection (June $27^{\mathrm{TH}}-30^{\mathrm{TH}}$, 2017, Bled, SLOVENIA), ENERGy MANAGEMENT AND Policies

J. Krope, A.Ghani Olabi, D. Goričanec \& S. Božičnik

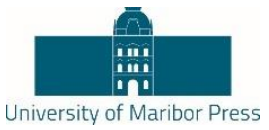

\title{
Comparison of Farmers' Risk Perception in Staw Supply Chain in Different Income Levels: A Case Study in a National Bioenergy Industry Area, Northeast China
}

\author{
LINGLING WANG \& TSUNEMI WATANABE
}

\begin{abstract}
This study compared the extent to which influencing factors predict farmers' risk perception and how such perception predicts the motivation of farmers with different income levels to supply straw. A sample of 275 farmers living around a bioenergy industry area were recruited. Results indicated that the factors affecting farmers' risk perception significantly differed across three income levels. For lowincome farmers, only government-issued economic incentives, as a policy guidance factor could predict risk perception. Trust factors significantly predicted risk perception in all the income levels, although the specific trust factors differed. For high-income farmers, risk perception regarding insufficient labor was a significant motivational factor. The implication of the results and cooperation strategies with farmers are discussed.
\end{abstract}

Keywords: • risk perception $\bullet$ farmers $\bullet$ straw supply $\bullet$ income level $\bullet$ China

$\bullet$.

CORRESPONDENCE ADDRESS: Lingling Wang, Kochi University of Technology, School of Economics and Management, 2-22 Eikokuji-cho, Kochi City, Kochi 780-8515, Japan, email: wang.lingling@kochi-tech.ac.jp. Tsunemi Watanabe, Kochi University of Technology, School of Economics and Management, 2-22 Eikokuji-cho, Kochi City, Kochi 780-8515, Japan; email: watanabe.tsunemi@kochi-tech.ac.jp. 
$10^{\mathrm{TH}}$ INTERNATIONAL CONFERENCE ON SUSTAINABLE ENERGY AND ENVIRONMENTAL Protection (June 27 $7^{\mathrm{TH}}-30^{\mathrm{TH}}, 2017$, Bled, Slovenia), ENERgy MANAGEMENT AND POLICIES

L. Wang \& T. Watanabe: Comparison of Farmers' Risk Perception in Staw Supply Chain in Different Income Levels: A Case Study in a National Bioenergy Industry Area, Northeast China

Concerns about climate change and air pollution and demands for energy have further increased the value of biomass energy [1]. The quest for renewable energy sources has promoted many countries to include biomass power on their agendas as an alternative to traditional fossil fuel energy [2]. Biomass presents many advantages that cannot be obtained from other renewable energy sources, such as wind, solar energy, and water; these advantages include larger benefits to local economic development, and less intermittence and seasonality [3]. Rural China enjoys abundant biomass resources, which are constituted primarily by agricultural residues, but not sufficiently utilized. Fully utilizing straw in rural China is critical for both renewable energy development and environmental conservation.

An urgent requirement in efficiently using crop residues is smoothening the operation of biomass supply chains. A well-functioning biomass supply chain can ensure access to sufficient bioenergy feedstock [4]. Yet most of biomass power plants currently struggle with financial deficits because of the insufficient collection of biomass [5]. Biomass supply chains have been studied from both qualitative [6] and game theory [7-9] perspectives. Barriers to such chains have also been discussed [10-12]. The efficiency of a biomass supply chain depends mostly on end-users' willingness, and risk perception. Farmers therefore play a critical role in ensuring the successful operation of a biomass supply chain given that they form the starting point of a straw supply chain. With these considerations in mind, this study categorized famers who supply straw to the chosen industry area into three groups, namely, low-, medium-, and high-income groups. The model of farmers' risk perception of straw supply (FROSS) [13] was then used as basis in conducting regression analysis for the comparison of risk perception among the different farmer groups and for the development of concrete strategies that reduce risk perception regarding the supply of straw to middlemen who serve as intermediaries between biomass power plants and farmers (i.e., They purchase straw from farmers and sell it to biomass power plants). The objectives of this study is to (1) explore the extent to which farmers' risk perception affecting factors could influence risk perception regarding straw supply of farmers in three difference income levels; (2) propose strategies with the derived idea of straw supply from the analysis of farmers in different income levels.

\section{$2 \quad$ Methodology}

The survey was administered face to face to grantee high quality results. The questionnaires were distributed to 300 farmers, and 275 valid questionnaires were returned. Of the 275 respondents, 101 were low-income farmers, 96 were mediumincome farmers, and 78 were high-income farmers. This survey contained questions about risk perception in relation to straw supply. These questions were presented to the farmers not only to determine their perceptions and attitudes toward straw supply, but 
$10^{\mathrm{TH}}$ INTERNATIONAL CONFERENCE ON SUSTAINABLE ENERGY AND ENVIRONMENTAL 101 Protection (June $27^{\mathrm{TH}}-30^{\mathrm{TH}}, 2017$, Bled, Slovenia), ENERgy MANAGEMENT AND POLICIES

L. Wang \& T. Watanabe: Comparison of Farmers' Risk Perception in Staw Supply Chain in Different Income Levels: A Case Study in a National Bioenergy Industry Area, Northeast China

also to derive ideas that can serve as reference in the development of supply chain strategies for farmers with different economic characteristics. The items that were measured on a Likert scale were treated as continuous variable $[15,16]$.

Basic statistical and multivariate techniques were employed for data analysis, which was conducted using SPSS 21.0. A multiple regression analysis was carried out to explore how influencing factors can predict the risk perception of farmers having three different income levels.

\section{$3 \quad$ Results}

\subsection{Farmers in three different income levels}

Wang and Watanabe [13] identified risk perception of farmers and determined its influencing factors, after which they developed the FROSS model. The influencing factors identified by the authors were policy guidance factors, economic factors, trust factors and socio-demographic characteristic. The current research used the FROSS model to identify the effects of aforementioned factors on the risk perception of farmers with different income levels regarding straw supply. According to the National Bureau of Statistic of China, the annual average income of low-, medium-, and high-income farmers in rural China are $\$ 964, \$ 1,386$, and $\$ 2,728$, respectively [14]. Our interview with local government officials indicated, however, that farmers' incomes are much higher than annual average income provided by the Bureau. Each farmer owns a large farmland, and most farmers secure part-time jobs in towns or cities during non-farming periods, thereby doubling of their earnings. The local governor of this study site estimated incomes to be US $\$ 2,756$ for low-income farmers, US $\$ 4,919$ for middle-income farmers, and US\$7,034 for high-income farmers. The differences among the respondents, were examined by testing homogeneity of variance; the results showed unequal variances among the three income levels $(p=.000)$. A one-way ANOVA was also conducted, $F(2$, $272=147.538), p=.000$, Mean Square $=20.550$. The Welch and Brown-Forsythe tests were carried out to support the results (Welch test $p=.000$, Brown-Forsythe $p=.000$ ).

\subsection{Risk perception and it influencing factors}

Using the predictors in FROSS model as basis, we conducted a multiple regression analysis to identify the specific factors that affect the farmers' risk perception and assess the extent to which these factors explain and predict risk perception regarding straw supply (Table 1). Age, education, effects of government-provided economic incentives, trust that middlemen will clear farmland at no extra cost to farmers, and a general feeling of trust toward middlemen could predict the risk perception of farmers with low income. All the significant factors explained $63.0 \%$ of the variance in risk perception, $F(14,86)$ $=13.187, \mathrm{Adj} . \mathrm{R}^{2}=.630, p=.000$. The beta weight of the medium-income farmers indicated that only trust factors, trust that farmers will not be cheated, and a general feeling of trust 
$10^{\mathrm{TH}}$ INTERNATIONAL CONFERENCE ON SUSTAINABLE ENERGY AND ENVIRONMENTAL Protection (June $27^{\mathrm{TH}}-30^{\mathrm{TH}}, 2017$, Bled, Slovenia), Energy Management AND POLICIES

L. Wang \& T. Watanabe: Comparison of Farmers' Risk Perception in Staw Supply Chain in Different Income Levels: A Case Study in a National Bioenergy Industry Area, Northeast China

toward middlemen significantly predicted the farmers' risk perception. The result explained $67.5 \%$ of the variance in risk perception, $F(14,86)=15.105$, Adj. $\mathrm{R}^{2}=.675$, $p=.000$. Among the high income farmers, education, income, meager profit, loss outweighing benefit, trust that farmers will not be cheated, and a general feeling of trust toward middlemen were significant predictors. This finding explained $66.7 \%$ of the variance in risk perception, $F(14,63)=12.037$, Adj. $\mathrm{R}^{2}=.667, p=.000$.

Table 1. Summary of results on factors affecting farmers' risk perception regarding straw supply.

\begin{tabular}{|l|c|c|c|}
\hline Style & $\begin{array}{l}\text { Low income } \\
\text { level }(\beta)\end{array}$ & $\begin{array}{l}\text { Medium } \\
\text { income level } \\
(\beta)\end{array}$ & $\begin{array}{l}\text { High } \\
\text { income } \\
\text { level }(\beta)\end{array}$ \\
\hline Age & $-.142^{*}$ & $n . s$ & $n . s$. \\
\hline Education & $-.152^{*}$ & $n . s$ & $-.155^{* *}$ \\
\hline Income of & $.168^{* *}$ & $n . s$ & $-.139^{*}$ \\
\hline $\begin{array}{l}\text { Effects } \\
\text { government- } \\
\text { provided economic } \\
\text { incentives }\end{array}$ & & $n . s$ & $n . s$. \\
\hline Meager profit & $n . s$ & $n . s$ & $.193^{*}$ \\
\hline $\begin{array}{l}\text { Losses } \\
\text { outweighing } \\
\text { benefits }\end{array}$ & $n . s$ & $n . s$ & $.176^{*}$ \\
\hline $\begin{array}{l}\text { Trust } \\
\text { middlemen will } \\
\text { clear farmland at } \\
\text { no extra cost to } \\
\text { farmers }\end{array}$ & $-.227^{* *}$ & $n . s$ & $n . s$ \\
\hline $\begin{array}{l}\text { Trust that farmers } \\
\text { will not be cheated }\end{array}$ & $n . s$ & $-.242^{* *}$ & $-.231^{* *}$ \\
\hline $\begin{array}{l}\text { A general feeling } \\
\text { of trust toward } \\
\text { middlemen }\end{array}$ & $-.196^{*}$ & $-.364^{* * *}$ & $-.263^{* *}$ \\
\hline $\mathrm{N}$. & .630 & .675 & .667 \\
\hline Adj. R 2 & $15.105^{* * *}$ & $12.037^{* * *}$ \\
\hline F value & $13.187^{* * *}$ & & \\
\hline
\end{tabular}

Notes: 1. Dependent variable: risk perception

2. ${ }^{*} p<0.1,{ }^{* *} p<0.05,{ }^{* * * *} p<0.01$

3. Only significant factors were listed $(n . s=$ non-significant $)$ 
$10^{\mathrm{TH}}$ INTERNATIONAL CONFERENCE ON SUSTAINABLE ENERGY AND ENVIRONMENTAL 103 Protection (June $27^{\mathrm{TH}}-30^{\mathrm{TH}}, 2017$, Bled, SLOVEnia), ENERgy MANAGEMENT AND POLICIES

L. Wang \& T. Watanabe: Comparison of Farmers' Risk Perception in Staw Supply Chain in Different Income Levels: A Case Study in a National Bioenergy Industry Area, Northeast China

\section{$4 \quad$ Discussion}

The main agricultural product in the study site is corn. As determined from the survey and the FROSS model, for the low-income farmers, demographic characteristics, such as age and education, were negatively related to risk perception and exert a significant effect on risk perception regarding straw supply. This finding suggests that young people hold a risk perception higher than that harbored by older people. Young farmers, especially those earning low incomes, experience more life burdens, and are therefore more concerned about their farmlands and the income that they can derive from selling straw. In terms of policy guidance factors, only factor of effects of government-provided economic incentives have influence on low-income farmers. This result is understandable because low-income farmers prefer to earn more income from selling straw. Economic factors (meager profit and losses outweighing benefits) served as predictors only among the high-income group. Economic factors (meager profit and losses outweighing benefits) served as predictors only among the high-income group. Because these farmers are frequently in more contact with middlemen and have more experience in such transactions. Correspondingly, they are burdened with more worries because they have encountered more undesirable experiences. In terms of trust factors, a general feeling of trust toward middlemen significantly affected the farmers in all the three income groups. Trust that middlemen will clear farmland at no extra cost to farmers significantly affected the low-income farmers, and trust that farmers will not be cheated significantly affected medium- and high-income farmers.

\section{$5 \quad$ Conclution and Policy Implementation}

This paper has presented an exploratory investigation based on data obtained from a survey administered to farmers living around a biomass power plant in China. The research has provided empirical support for the long-held beliefs that farmers' risk perception is affected by economic factors, policy guidance factors, trust factors, and demographic characteristic.

There are three policy implementations in this study. First, in the process of straw supply, mitigating farmers' risk perception is important to motivate farmers to cooperate with middleman. Hence, farmers' risk perception affecting factors play critical role in mitigation of risk perception. To smoothen the supply chain, farmers' characteristic, policy guidance factors, economic factors, and trust factors are necessary to be considered. Second, for farmers with low income, education is necessary to change their conservative attitude towards straw supply. Trust is also an important obstacle for lowincome farmers to supply straw. Therefore, to build trust with farmers, middlemen need to be more considerable to farmers. Third, for medium- and high-income farmers, trust is particular important. Without trust, they would not take advantage of opportunities to transact with middlemen. These implications indicate that realizing the smooth operation of straw supply chains requires middlemen to change their strategy for building trust with 
$10^{\mathrm{TH}}$ INTERNATIONAL CONFERENCE ON SUSTAINABLE ENERGY AND ENVIRONMENTAL Protection (June $27^{\mathrm{TH}}-30^{\mathrm{TH}}, 2017$, Bled, Slovenia), Energy Management AND POLICIES

L. Wang \& T. Watanabe: Comparison of Farmers' Risk Perception in Staw Supply Chain in Different Income Levels: A Case Study in a National Bioenergy Industry Area, Northeast China

farmers. Therefore, investigating risk perception of farmers with different income levels is necessary for offering training to middlemen to further improve their relationship with farmers.

\section{Acknowledgements}

The authors would like to acknowledge Mr. Wang, the manager of national bioenergy power plant; Mr. Sun, and Mr. Li, the local governor, who provided the important information of the biomass power plant and the situation of the local people, also assisted us to do field survey. This research was financially supported by a Kochi University of Technology.

\section{References}

[1] Rulli MC, Saviori A, D'Odorico P., "Global land and water grabbing," Proceedings of the National Academy of Sciences, vol. 110, pp. 892-7, 2013.

[2] German L, Schoneveld G., "A review of social sustainability considerations among EUapproved voluntary schemes for biofuels, with implications for rural livelihoods," Energy Policy, vol. 51, pp. 765-78, 2012.

[3] Zhao Z-Y, Zuo J, Fan L-L, Zillante G. "Impacts of renewable energy regulations on the structure of power generation in China-a critical analysis," Renewable Energy, vol. 36, pp. 24-30, 2011.

[4] De Laporte AV, Weersink AJ., McKenney DW. "Effects of supply chain structure and biomass prices on bioenergy feedstock supply," Applied Energy, vol. 183, pp.1053-64, 2016.

[5] Wang L, Watanabe T., "A Stackelberg Game Theoretic Analysis of Incentive Effects under Perceived Risk for China's Straw-Based Power Plant Supply Chain,” Energies, vol. 9, pp. 455, 2016.

[6] de Lourdes Bravo M, Naim MM, Potter A., "Key issues of the upstream segment of biofuels supply chain: a qualitative analysis," Logistics Research, vol. 5, pp. 21-31, 2012.

[7] Bai Y, Ouyang Y, Pang J-S, "Biofuel supply chain design under competitive agricultural land use and feedstock market equilibrium," Energy Economics, vol. 34, pp. 1623-33, 2012.

[8] Luo Y, Miller S, “A game theory analysis of market incentives for US switchgrass ethanol," Ecological Economics, vol. 93, pp. 42-56, 2013.

[9] Nasiri F, Zaccour G., "An exploratory game-theoretic analysis of biomass electricity generation supply chain," Energy Policy, vol. 37, pp. 4514-22, 2009.

[10] Ebadian M, Sowlati T, Sokhansanj S, Townley-Smith L, Stumborg M., "Modeling and analysing storage systems in agricultural biomass supply chain for cellulosic ethanol production," Applied energy, vol. 102, pp. 840-9, 2013.

[11] Rentizelas AA, Tolis AJ, Tatsiopoulos IP., "Logistics issues of biomass: the storage problem and the multi-biomass supply chain," Renewable and Sustainable Energy Reviews, vol. 13, pp. 887-94, 2009.

[12] Sharma B, Ingalls R, Jones C, Khanchi A. "Biomass supply chain design and analysis: basis, overview, modeling, challenges, and future," Renewable and Sustainable Energy Reviews, vol. 24, pp. 608-27, 2013. 
L. Wang \& T. Watanabe: Comparison of Farmers' Risk Perception in Staw Supply Chain in Different Income Levels: A Case Study in a National Bioenergy Industry Area, Northeast China

[13] Wang L, Watanabe T., "Factors affecting farmers' risk perceptions regarding biomass supply: A case study of the national bioenergy industry in northeast China," Journal of Cleaner Production, vol. 139, pp. 517-26, 2016.

[14] Natioanl Bureau of Statistics of China. China Statistical Yearbook. China Statistics Press, 2015.

[15] Lien G, Hardaker JB, Flaten O., "Risk and economic sustainability of crop farming systems," Agricultural Systems, vol. 94, pp. 541-52, 2007.

[16] Meuwissen M, Huirne R, Hardaker J. "Risk and risk management: an empirical analysis of Dutch livestock farmers," Livestock production science, vol. 69, pp. 43-53, 2001. 
$106 \quad 10^{\mathrm{TH}}$ INTERNATIONAL CONFERENCE ON SUSTAINABLE ENERGY AND ENVIRONMENTAL

Protection (June 27 $7^{\mathrm{TH}}-30^{\mathrm{TH}}, 2017$, Bled, Slovenia), EnERgy Management AND POLICIES 
$10^{\mathrm{TH}}$ InTERnAtional CONFERENCE ON Sustainable ENERgy AND ENVIRONMENTAL Protection (June $27^{\mathrm{TH}}-30^{\mathrm{TH}}$, 2017, Bled, SLOVENIA), ENERGy MANAGEMENT AND Policies

J. Krope, A.Ghani Olabi, D. Goričanec \& S. Božičnik

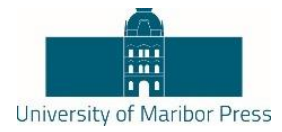

\title{
Patterns of Energy Consumption, GDP and $\mathrm{CO}_{2}$ Emissions in China
}

\author{
Bing Gong, QIng GuO, JoAquín ORdieres-Meré \& XiAOCHEN ZHENG
}

\begin{abstract}
The goal of this paper is to analyze the patterns of energy consumption, GDP share and $\mathrm{CO}_{2}$ emissions with accountability in China at the province level. The main reasons for the interest are that China is one of the world's greatest contributors to pollution and the central government determines policy, whereas implementation is the responsibility of the provinces. Depending on the specific strategies adopted at province level, different patterns are observed. Learning the relationship between those patterns according to different indicators will help decision makers to establish new, updated policies.
\end{abstract}

Keywords: • Energy consumption • $\mathrm{CO} 2$ emissions • materialization • dematerialization $\bullet$ decarbonization $\bullet$

CORRESPONDENCE AdDREsS: Bing Gong, MsC, PMQ research member. Technical University of Madrid, Calle de José Gutiérrez Abascal, 2, 28006 Madrid, Spain; bing.gong@alumnos.upm.es. Qing Guo, PhD. Associate Professor, Guangdong University of Foreign Studies, School of Economics and Trade, 2 Baiyun N Ave, Baiyun Qu, Guangzhou Shi, Guangdong Sheng 510420, China; qingguovip@gmail.com. Joaquín Ordieres-Meré, PhD, Full Professor, PMQ research member. Technical University of Madrid, Calle de José Gutiérrez Abascal, 2, 28006 Madrid, Spain, j.ordieres@upm.es. Xiaochen Zheng MsC, PMQ research member. Technical University of Madrid, Calle de José Gutiérrez Abascal, 2, 28006 Madrid, Spain, xiaochen.zheng@alumnos.upm.es. 
$10^{\mathrm{TH}}$ INTERNATIONAL CONFERENCE ON SUSTAINABLE ENERGY AND ENVIRONMENTAL Protection (June $27^{\mathrm{TH}}-30^{\mathrm{TH}}, 2017$, Bled, Slovenia), Energy Management AND POLICIES

B. Gong, Q. Guo, J. Ordieres-Meré \& X. Zheng: Patterns of Energy Consumption, GDP and $\mathrm{CO}_{2}$ Emissions in China

Albeit the technological disruptions and innovations, increasing pollution and ecosystem contamination continue to be pressing issues across the globe [1]. China's rapid increase in urbanization in the last three decades, for example, has resulted in burgeoning environmental challenges in which air pollution is the number one problem [2].

Protecting the environment, therefore, is a serious concern that drives businesses and governments today.

In recent years, there have been increasing pressures for institutions to measure and report environmental impacts [3]. $\mathrm{CO}_{2}$ is one of the greenhouse gas that is responsible for globing warming. Burning fuels to provide energy for transportation, industry, agriculture, commercial and residential properties, etc. is the main contributor to $\mathrm{CO}_{2}$.

Therefore, the issues that are related to energy, pollution and its related health and other impacts have sparked considerable attention from e citizens, governments and a number of researchers.

China, a large greenhouse gas emitter, has surpassed the United States to become the largest $\mathrm{CO}_{2}$ emitter in the world. China now accounts for $25 \%$ of the world's carbon emissions [4].

In achieving this, the Chinese government has implemented a series of actions and regulation to deal with climate change. For instance, in 2016, the Chinese government announced China's proposed $13^{\text {th }}$ Five-Year Plan [5]. To achieve the emission reduction target, local pollution abatement should be implemented.

China, as one of the largest countries in area, experiences very different distribution patterns of economic performance, energy consumption and population. Therefore, very different behaviours can be expected of the provinces, sectors and regions.

Since the anthropogenic $\mathrm{CO}_{2}$ emissions are highly related to socioeconomic activities, such as GDP and urbanization, it is necessary to analyze the $\mathrm{CO}_{2}$ emission patterns considering these factors as well. The interest will be to understand the dynamic changes of energy usage and $\mathrm{CO}_{2}$ emission in relation to the social-economic activities. Therefore, a comprehensive analysis that considers carbon emissions and other factors will be required to propose a proper policy, such as allocated national emissions by province, in order to achieve the nation's carbon emission target.

Finally, the expected outcome of the paper is help to understand the main drivers in long term behaviour and different implementations strategies in order to promote feasible policies, and suggest best practices looking at those implementations. 
$10^{\mathrm{TH}}$ INTERNATIONAL CONFERENCE ON SUSTAINABLE ENERGY AND ENVIRONMENTAL Protection (June $27^{\mathrm{TH}}-30^{\mathrm{TH}}, 2017$, Bled, SLovenia), ENERGy MaNagement AND 109 Policies
B. Gong, Q. Guo, J. Ordieres-Meré \& X. Zheng: Patterns of Energy Consumption,
GDP and $\mathrm{CO}_{2}$ Emissions in China

\section{$2 \quad$ State of the Art}

The study from [6] explored the regional characteristics of inter-provincial $\mathrm{CO}_{2}$ emissions and the regional distribution of the reduction of emission intensity reduction in China by K-means, Hierarchical clusters, and PSO-FCM clustering algorithms. The latter is a method that uses the Particle Swarm Optimization(PSO) on Fuzzy-C means (FCM). To differ from the previous traditional studies that divided China into eastern, central and western regions, the aforementioned research examined how the regions correspond to the divisions by economic developing level. Moreover, five indices, including total emission, per capital emissions, $\mathrm{CO}_{2}$ emissions per GDP (intensity of $\mathrm{CO}_{2}$ emission), $\mathrm{CO}_{2}$ emissions per unit of energy and the proportion of industrial $\mathrm{CO}_{2}$ emissions, have been considered to characterize $\mathrm{CO}_{2}$ emissions in China.

Research from [7] analyzed $\mathrm{CO}_{2}$ emission levels due to energy production in cities in China by DMSP/OLS night time light imageries and explored major driving forces to propose feasible mitigation policies. A recommendation is made to reduce the growth rate of $\mathrm{CO}_{2}$ without compromising economic development by optimizing the industrial structure of technology intensive areas and improving energy efficiency in other areas.

The study [8], on the other hand, compares transport development and energy use with a focus on $\mathrm{CO}_{2}$ emissions in the EU15 countries. Three aspects that are related to energy and emissions were examined.. They are, immaterialization, dematerialization and decarbonization. Immaterialization refers to the reduction in energy and transport intensities, and can be measured by the indicator (energy/GDP). Dematerialization was defined as the reduction of carbon intensity of energy production and the carbon intensity of transport $\left(\mathrm{CO}_{2} /\right.$ energy). Decarbonization is the reduction in carbon of the whole economy. It can be seen as a link between immaterialization and dematerialization, and is measured by the carbon intensity of the economy $\left(\mathrm{CO}_{2} / \mathrm{GDP}\right)$. This study groups EU15 countries based on each of three aforementioned indicators in order to establish different patterns. The limitation of this study is that it lacks a statistical analysis to identify the main influential factors in each group.

A special Impact of Human Activity on the environment (IPAT) identify case that reveals the importance of distinct components or factors in the historical data of energy related $\mathrm{CO}_{2}$ emissions, has been widely utilized in many studies [9]. It is often called KAKY identity. This research separates urban emissions into four components (emissions from primary, secondary and tertiary industry and residential areas) to obtain the result of the interactions among 13 macro influential factors. Thirty provinces in China were ranked on the basis of historical data of those macro factors. Shapley value decomposition has been used to identify the key factors with a result that the related policy control was promoted. 
$110 \quad 10^{\mathrm{TH}}$ INTERNATIONAL CONFERENCE ON SUSTAINABLE ENERGY AND ENVIRONMENTAL Protection (June $27^{\mathrm{TH}}-30^{\mathrm{TH}}, 2017$, Bled, Slovenia), ENERgy Management AND POLICIES

B. Gong, Q. Guo, J. Ordieres-Meré \& X. Zheng: Patterns of Energy Consumption, GDP and $\mathrm{CO}_{2}$ Emissions in China

The main limitation of the existing arrangement is that it lacks a dynamic view to reveal the changes in China's energy usage and $\mathrm{CO}_{2}$ emissions, or fails to use modelling to identify the main important factors for different dynamic indicators.

To bridge the identified gap, this study aims to analyze dynamically the patterns of energy usage and $\mathrm{CO}_{2}$ emissions at the provincial level by utilizing the indicators, immaterialization, dematerializaion and decarbonization. The study will cover thirty provinces in China, and will include the four largest megacities in the analyses, which have provincial status in China based on the Chinese political and administrative system (see Figure 1).

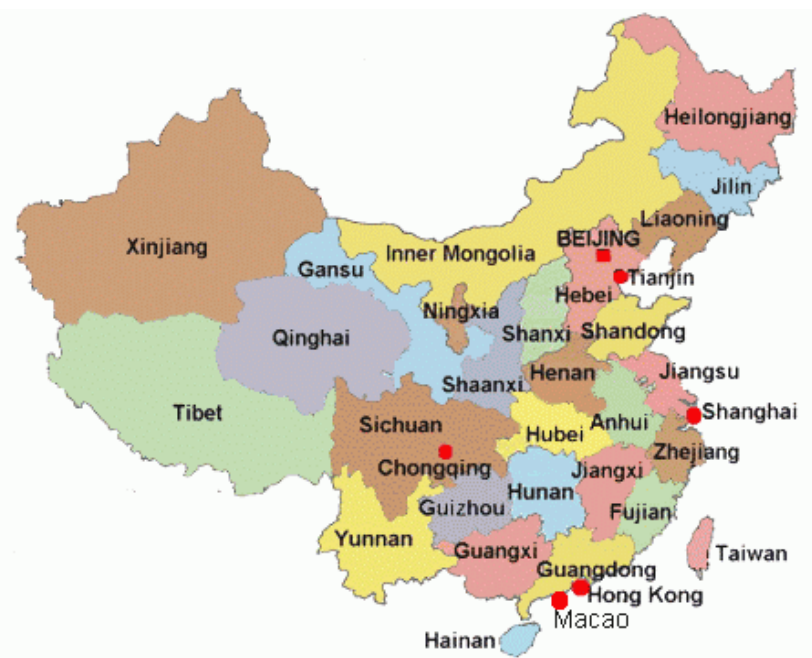

Figure 1. Provincial Map of China

\section{$3 \quad$ Methodology}

All data were obtained from the Chinese yearbook, including energy usage for each type and province, GDP and urbanization for each province.

This study focuses on the ninth, tenth, eleventh, and twelfth Five Years Plan (FYP), which were for 1996 to 2000, 2001 to 2005, 2006 to 2010 and 2011 to 2016 respectively.

Due to lack of $\mathrm{CO}_{2}$ emission statistics in China, $\mathrm{CO}_{2}$ will be calculated by the types of energy and their corresponding $\mathrm{CO}_{2}$ emission factors that are provided by the Intergovernmental Panel on Climate Change(IPCC) [10].

This approach was adopted by most of the existing studies [6], [7]. The $\mathrm{CO}_{2}$ conversion for each province (j) was calculated by means of Equation (1). 
$10^{\mathrm{TH}}$ INTERNATIONAL CONFERENCE ON SUSTAINABLE ENERGY AND ENVIRONMENTAL

B. Gong, Q. Guo, J. Ordieres-Meré \& X. Zheng: Patterns of Energy Consumption,

$\left(\mathrm{CO}_{2}\right)_{j}=\frac{44}{11} \sum_{i=1}^{N} K_{i} E_{i}$

where $K_{i}$ reflects the conversion factor for energy $E_{i}$. In this work 18 types of energy have been considered (see Table 1). The cumulative effects will be given by the summation by province.

Table 1. Energies and Conversion Factors

\begin{tabular}{|l|r|}
\hline Energy Type & K factor \\
\hline Raw Coal & 2,69 \\
\hline Cleaned Coal & 3,09 \\
\hline Other Washed Coal & 1,98 \\
\hline Briquettes & 1,55 \\
\hline Coke & 3,14 \\
\hline Coke Oven Gas & 0,93 \\
\hline Other Gas & 0,88 \\
\hline Crude Oil & 2,76 \\
\hline Gasoline & 2,26 \\
\hline Kerosene & 2,56 \\
\hline Diesel Oil & 2,73 \\
\hline LPG & 1,75 \\
\hline Refinery Gas & 2,98 \\
\hline Natural Gas & 2,09 \\
\hline Other Petroleum Products & 2,76 \\
\hline Other Coking Products & 3,14 \\
\hline Other Energy & 2,74 \\
\hline
\end{tabular}

Using the annual GDP, energy consumption and $\mathrm{CO}_{2}$ consumption data, the immaterialization, dematerialization and decarbonization per province are identified by equations (2-4).

Immaterialization $=\frac{E_{y 2}-E_{y 1}}{G D P_{y 2}-G D P_{y 1}}$

Dematerialization $=\frac{\left(\mathrm{CO}_{2}\right)_{y_{2}}-\left(\mathrm{CO}_{2}\right)_{y 1}}{E_{y 2}-E_{y 1}}$

Decarbonization $=\frac{\left(\mathrm{CO}_{2}\right)_{y_{2}}-\left(\mathrm{CO}_{2}\right)_{y 1}}{G D P_{y_{2}}-G D P_{y_{1}}}$

The approach adopted in this paper was to cluster different indicators per province by considering the outcomes from different periods. The acronyms for those provinces are presented in Table 2. Two different cluster technologies were used in order to compare 
112 10 $10^{\mathrm{TH}}$ INTERNATIONAL CONFERENCE ON SUSTAINABLE ENERGY AND ENVIRONMENTAL Protection (June 27 $7^{\mathrm{TH}}-30^{\mathrm{TH}}, 2017$, Bled, Slovenia), EnERgy Management AND POLICIES

B. Gong, Q. Guo, J. Ordieres-Meré \& X. Zheng: Patterns of Energy Consumption, GDP and $\mathrm{CO}_{2}$ Emissions in China

the findings. Agglomerative hierarchical clustering and Mixed Gaussian based models were considered.

Table 2. Acronyms per Area

\begin{tabular}{|l|c|l|c|}
\hline Area Name & $\begin{array}{l}\text { Acro- } \\
\text { nym }\end{array}$ & Area Name & Acro-nym \\
\hline Bei Jing & BJ & He Nan & HN \\
\hline Tian Jin & TJ & Hu Bei & HuB \\
\hline He Bei & HeB & Hu Nan & HuN \\
\hline Shan Xi & ShanX & Guang Dong & GD \\
\hline Inner Mongolia & IM & Guang Xi & GX \\
\hline Liao Ning & LN & Hai Nan & HaiN \\
\hline Ji Lin & JL & Chong Qing & CQ \\
\hline Hei Long Jiang & HLJ & Si Chuan & SC \\
\hline ShangHai & SH & Gui Zhou & GZ \\
\hline Jiang Su & JS & Yu Nan & YN \\
\hline Zhe Jiang & ZJ & ShannXi & ShannX \\
\hline An Hui & AH & GanSu & GS \\
\hline Fu Jian & FJ & QingHai & QH \\
\hline Jiang Xi & JX & NingXia & NX \\
\hline Shang Dong & SD & XinJiang & XJ \\
\hline
\end{tabular}

\section{$4 \quad$ Results}

Figure 2 shows the 15 provinces that had the highest $\mathrm{CO}_{2}$ emission volumes in 1996, 2001, 2006 and 2011. In 1996, $\mathrm{CO}_{2}$ emission volumes of all provinces were below $25000 \mathrm{kT}$. HeB, JS, LN and SD are the provinces with the highest $\mathrm{CO}_{2}$ emissions.

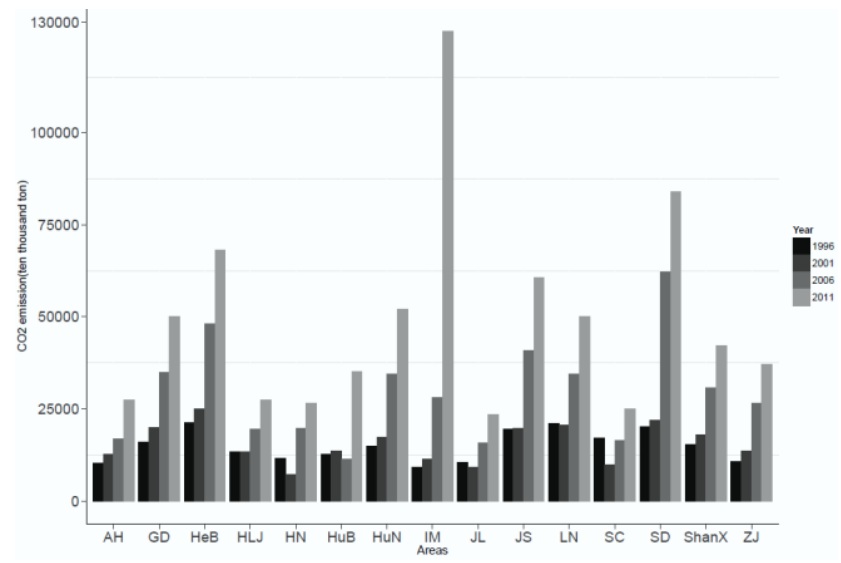

Figure 2. Highest $\mathrm{CO}_{2}$ levels in China (1996-2011) 
From 1996 to 2001, the increase in $\mathrm{CO}_{2}$ emissions was minimal. Some provinces, like $\mathrm{HN}$, JL and SC, showed a downward trend in $\mathrm{CO}_{2}$ emissions. Since 2001, the growth in $\mathrm{CO}_{2}$ emissions has become very notable. $\mathrm{CO}_{2}$ emissions rose in some areas such as $\mathrm{HeB}$, HuN, IM, JS and SD. In SD province, they had more than doubled to $61250 \mathrm{kT}$ by 2011 from $25000 \mathrm{kT}$ in 2006. In 2011, IM province experienced the severest $\mathrm{CO}_{2}$ pollution with more than $12500 \mathrm{kT}$, followed by SD and $\mathrm{HeB}$, with approximately $7500 \mathrm{kT}$.

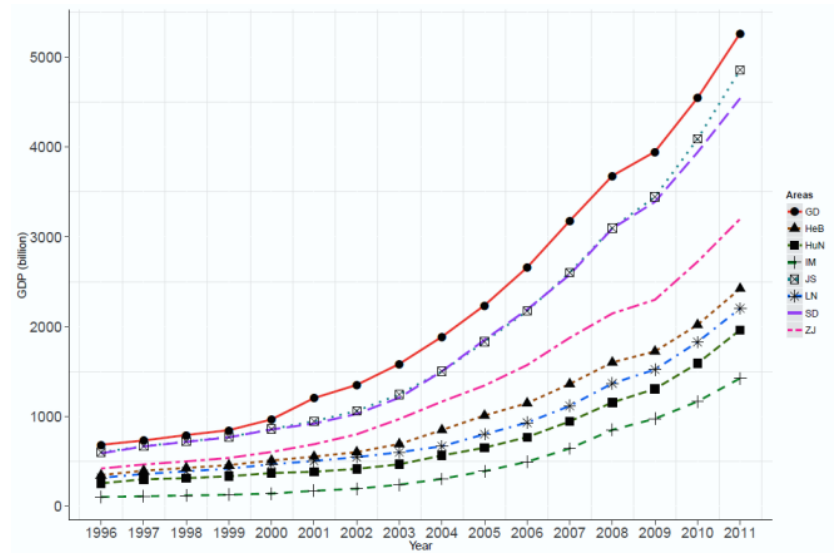

Figure 3. GDP trend for some provinces.

Figure 3 shows the GDP values of the provinces in China that have the highest $\mathrm{CO}_{2}$ levels. These provinces are GD, HeB, HuN, IM, JS, LN, SD, and ZJ. GD is the area in which GDP values increased most notably during this period, from 800 billion (RMB) in 1996 to more than 5000 billion in 2011. IM grows its economy more slowly than the other seven areas, even with highest $\mathrm{CO}_{2}$ emissions. It can be seen that, the economy of these provinces grew slowly before 2002, but rose considerably afterward. Figure 2 and Figure 3 both show that the most pollutant province might not be the most developed ones in China (For example IM). Meanwhile, a province like ZJ could have a higher GDP, but relatively low $\mathrm{CO}_{2}$ pollution.

Figure 4 shows the energy consumption structure in year 2012 in China. Raw coal (66\%) was still the main energy source in China until 2012. It is followed by cleaned coal and crude oil, which accounted for $9 \%$ and $7 \%$ of total energy consumption respectively. It clearly demonstrates that the clean energy was not widely used before 2012 . 
$11410^{\mathrm{TH}}$ INTERNATIONAL CONFERENCE ON SUSTAINABLE ENERGY AND ENVIRONMENTAL Protection (June 27 $7^{\mathrm{TH}}-30^{\mathrm{TH}}, 2017$, Bled, Slovenia), EnERgy Management AND Policies

B. Gong, Q. Guo, J. Ordieres-Meré \& X. Zheng: Patterns of Energy Consumption, GDP and $\mathrm{CO}_{2}$ Emissions in China

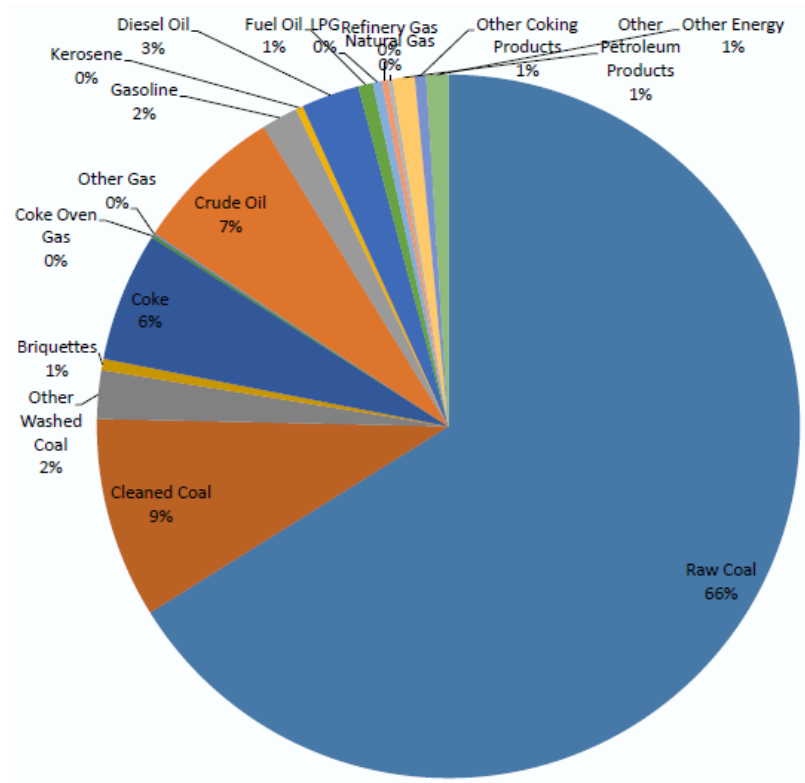

Figure 4. Structure of China's Energy consumption in 2012.

In regards to the results based on the three indicators (i.e., immaterialization, dematerialization, and decarbonization), it is necessary to remember that, in China, the central government usually determines the high level policies and the local governments' or city governments are responsible for their implementation.

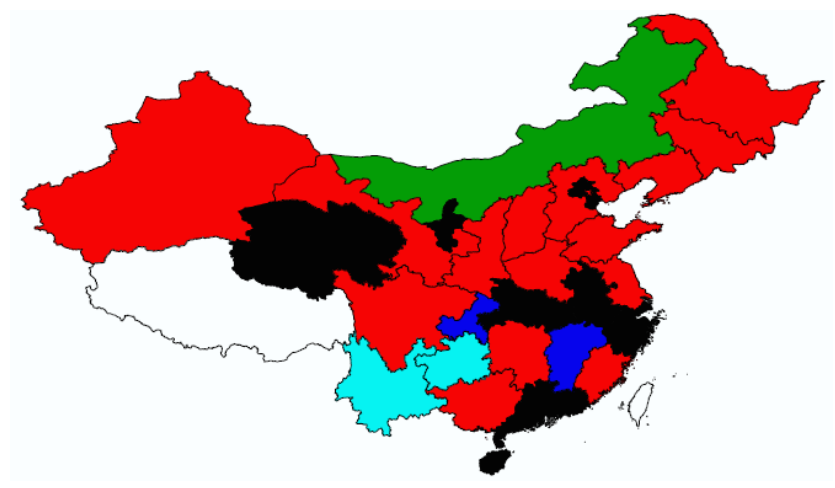




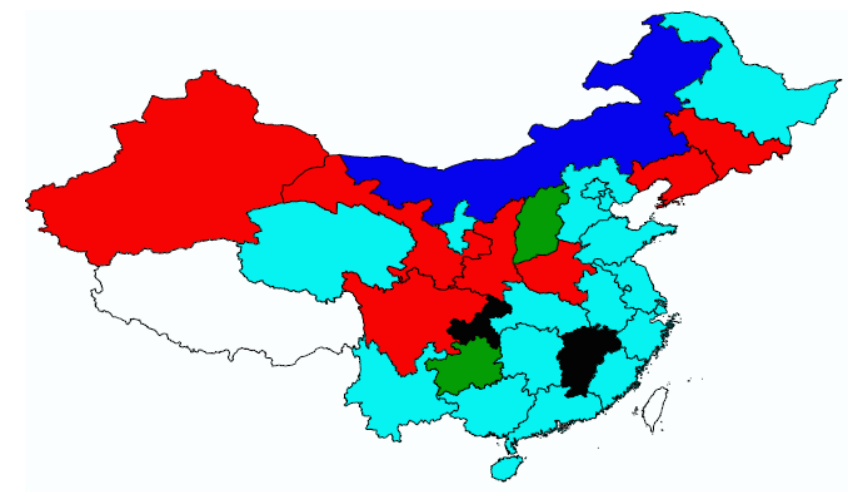

Figure 5. Results for immaterialization indicators.Top: Hierarchical and bottom: Gaussian clusters.

Because of such distribution of responsibilities, it is important to understand the characteristics of provinces with similar behaviour and different indicators, in order to design effective policies to reduce emissions.

Figure 5 shows the agglomerative hierarchical and Gaussian mixed clustering models based on indicator immaterialization $(\Delta($ energy/GDP $)$ ). Based on Gaussian mixed modeling, the provinces of JX and CQ are grouped in cluster one. LN, JL, HN, SC, ShannX, GS, and XJ belong to cluster two. Cluster three includes ShanX and GZ, whereas cluster four contains only IM. The rest of the provinces are clustered together.

The discrimination patterns of the energy intensity (immaterialization) among clusters probably result from the industrial structures' changes from low-energy, intensive industry to high-energy, intensive industry or the reverse. One of the measurements that discriminate the industrial structures is the investment in each type of industry, as well as the usage patterns of various types of energy [8].

The change of energy against of GPD could reflect both material production and consumption from economic production [8]. It reveals that the energy intensity $\Delta$ (energy/GDP) decreased during the three periods for the most provinces, except the $9^{\text {th }}$ FYP for CQ and JX, the $10^{\text {th }}$ FYP for HN, FJ, SD and YN, 11TH FYP for IM and HB.

As mentioned before, no matter which clustering methods are used in this study, CQ and JX are grouped together. The pattern in this cluster is characterized by considerably increasing energy intensity in the first period, a decreasing trend in the second period and a slight changes in the third period. This is probably due to the energy consumption structure of these two provinces. 
$116 \quad 10^{\mathrm{TH}}$ INTERNATIONAL CONFERENCE ON SUSTAINABLE ENERGY AND ENVIRONMENTAL Protection (June $27^{\mathrm{TH}}-30^{\mathrm{TH}}, 2017$, Bled, SLOVENiA), ENERGy MANAGEMENT AND POLICIES

B. Gong, Q. Guo, J. Ordieres-Meré \& X. Zheng: Patterns of Energy Consumption, GDP and $\mathrm{CO}_{2}$ Emissions in China

Indicator dematerialization $\Delta\left(\mathrm{CO}_{2} /\right.$ energy $)$ can reflect the environmental harm from material production. Based on this indicator, the provinces are separated into three groups according to BIC. CQ and JX belong to one cluster, whereas NX and ShannX are grouped together. The remaining provinces are in the same cluster.

In Figure 6, there are considerable changes in provinces CQ, JX, NX and ShannX. CQ and JX reduced their carbon intensity of energy production $\Delta(\mathrm{CO} 2 /$ energy) significantly. Therefore, the notable increase of $\Delta(\mathrm{CO} 2 /$ energy $)$ in the first period for the two provinces is probably due to the increasing raw coal consumption. The reason for the pattern of CO2/energy should be the same as CQ and JX. Conversely, these two aggregated provinces reduce the raw coal energy consumption percentage in the first period, but increase it in the second period.

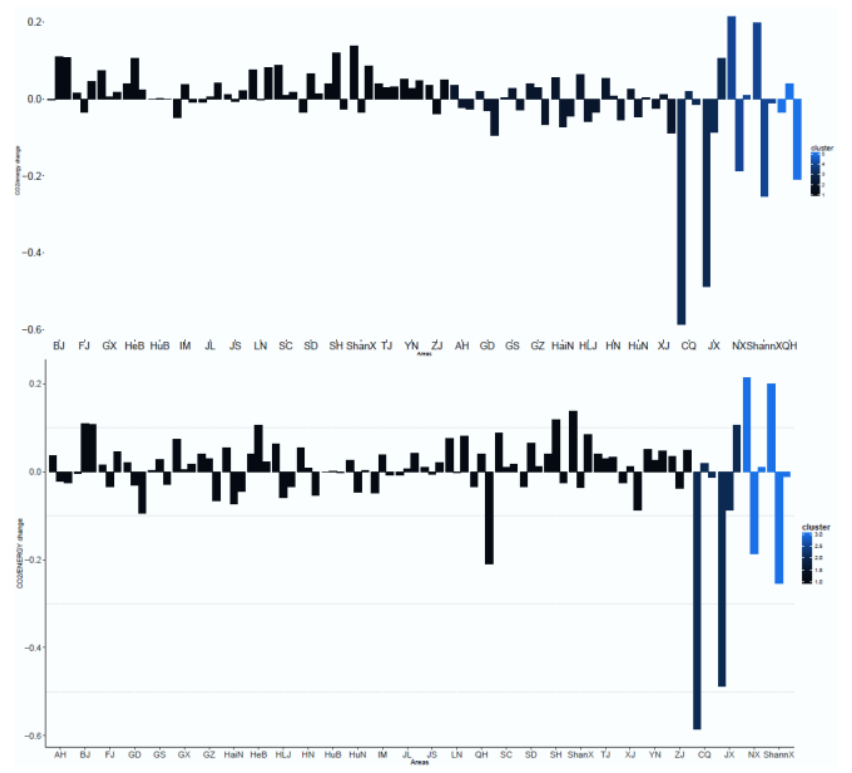

Figure 6. Clustered dematerialization indicator by provincial level.

\section{$5 \quad$ Conclusions}

In this study, the provinces in China have been clustered by immaterialization, dematerialization and decarbonization indicators in order to understand the similar pattern in the same cluster, and the different patterns among the clusters. For each of the indicators, two extremely disparate clusters and their possible driven factors were analyzed and discussed. Although the work is underway, some preliminary results can be summarized as follows: 
$10^{\mathrm{TH}}$ INTERNATIONAL CONFERENCE ON SUSTAINABLE ENERGY AND ENVIRONMENTAL

B. Gong, Q. Guo, J. Ordieres-Meré \& X. Zheng: Patterns of Energy Consumption, GDP and $\mathrm{CO}_{2}$ Emissions in China

- The provinces in China have been grouped based on three indicators (immaterialization, dematerialization and decarbonization) that are characterized as dynamic representations of the interaction among the energy usage, $\mathrm{CO}_{2}$ emissions, and GDP.

- From the description analysis, the driving factor for immaterialization could be related to the added value of primary, secondary, and tertiary sectors. For dematerialization, the influencing factor could be related to the changes in the raw coal usage.

- Other factors such as the changes in urbanization rate cannot be connected at the present time with the indicators.

The research is underway to increase the level of explanatory relationship between indicators and aggregated behaviour. The greater the knowledge, the better will be the help to decision makers that can be provided.

\section{Acknowledgements}

The authors want to thank China Scholarship Council for the support it provided for this work.

\section{References}

[1] Global Reporting Initiative, "Sustainability and Reporting Trends in 2025 - Preparing for the Future -," no. May, p. 19, 2015.

[2] Ernst \& Young, "Rapid-growth markets," no. July, 2014.

[3] KPMG, "Ten emerging trends in 2017," no. January, 2017.

[4] S. Shao, J. Liu, Y. Geng, Z. Miao, and Y. Yang, "Uncovering driving factors of carbon emissions from China's mining sector," Appl. Energy, vol. 166, pp. 220-238, Mar. 2016.

[5] S. W. NG, N. Mabey, and J. Gaventa, "Pulling Ahead on Clean Technology: China's 13th Five Year Plan Challenges Europe's Low Carbon Competitiveness," Brief. Pap. E3G, London, 2016.

[6] S. Yu, Y.-M. Wei, J. Fan, X. Zhang, and K. Wang, "Exploring the regional characteristics of inter-provincial $\mathrm{CO}_{2}$ emissions in China: an improved fuzzy clustering analysis based on particle swarm optimization," Appl. Energy, vol. 92, pp. 552-562, 2012.

[7] Y. Su, X. Chen, Y. Li, J. Liao, Y. Ye, H. Zhang, N. Huang, and Y. Kuang, "China's 19year city-level carbon emissions of energy consumptions, driving forces and regionalized mitigation guidelines," Renew. Sustain. Energy Rev., vol. 35, pp. 231-243, 2014.

[8] P. Tapio, D. Banister, J. Luukkanen, J. Vehmas, and R. Willamo, "Energy and transport in comparison: Immaterialisation, dematerialisation and decarbonisation in the EU15 between 1970 and 2000," Energy Policy, vol. 35, no. 1, pp. 433-451, 2007.

[9] S. Yu, Y.-M. Wei, and K. Wang, "Provincial allocation of carbon emission reduction targets in China: An approach based on improved fuzzy cluster and Shapley value decomposition," Energy Policy, vol. 66, pp. 630-644, 2014.

[10] I. P. on Climate Change, Climate Change 2014--Impacts, Adaptation and Vulnerability: Regional Aspects. Cambridge University Press, 2014. 
$118 \mid 10^{\text {Th }}$ INTERNATIONAL CONFERENCE ON SUSTAINABLE ENERGY AND ENVIRONMENTAL Protection (June $27^{\mathrm{TH}}-30^{\mathrm{TH}}, 2017$, Bled, Slovenia), Energy Management And POLICIES 
$10^{\mathrm{TH}}$ InTERnational CONFERENCE ON Sustainable ENERgy AND

ENVIRONMENTAL Protection (June $27^{\mathrm{TH}}-30^{\mathrm{TH}}$, 2017, Bled,

SLOVENIA), ENERGy MANAGEMENT AND Policies

J. Krope, A.Ghani Olabi, D. Goričanec \& S. Božičnik

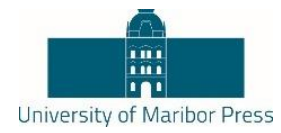

\title{
Multi-Criteria Approach to Sustainability Evaluate of District Heating System Scenarios in Case of Serbia
}

\author{
MARINA JOVANOVIĆ, VUKMAN BAKIĆ, VALENTINA TURANJANIN \& BILJANA VuČIĆEVIĆ
}

\begin{abstract}
Today, the district heating system in Serbia with an installed capacity of 6,600 MW supplying 58 towns with thermal energy. Special importance for Serbia as a candidate country for accession to the European Union, and in particular on issues related to the environment, the obligation to reduce the level of greenhouse gas emissions. Current work presents basic and three alternative scenarios of final energy consumption in the district heating sector for 2015, 2020 and 2025 years. This paper has proposed that heat demand to be $10 \%$ higher in 2020 and $15 \%$ in 2025 than the consumption in 2015, while the share of each energy carriers does not change. Changing the structure of energy sources for heat supply assumes decrease in the share of coal and liquid fuel, and increase the share of biomass and natural gas. The obtained results were compared by the General Index of Sustainability which is a measure of the complexity of proposed energy scenario. Paper considers formation of related energy indicators as a quantitative tool that analyses changes. In this way, the results of multi-criteria assessment can help in the decision making process in cases where is considered equally influence between economic, social and ecological criteria.
\end{abstract}

Keywords: • district heating system $\bullet$ energy scenarios $\bullet$ sustainability $\bullet$ multi-criteria decision $\bullet$ Serbia $\bullet$

CoRRESPONDENCE AdDRESS: Marina Jovanović, Ph.D., Associate research professor, University of Belgrade, Institute for Nuclear Science Vinča, Laboratory for Thermal Engineering and Energy, PO.Box. 522, 11000 Belgrade, Serbia, email: marinaj@vinca.rs. Vukman Bakić, Ph.D., Research professor, University of Belgrade, Institute for Nuclear Science Vinča, Laboratory for Thermal Engineering and Energy, PO.Box. 522, 11000 Belgrade, Serbia, email: bakicv@ vinca.rs. Valentina Turanjanin, Ph.D., Associate research professor, University of Belgrade, Institute for Nuclear Science Vinča, Laboratory for Thermal Engineering and Energy, PO.Box. 522, 11000 Belgrade, Serbia, email: valentin@vinca.rs. Biljana Vučićević, Ph.D., Associate research professor, University of Belgrade, Institute for Nuclear Science Vinča, Laboratory for Thermal Engineering and Energy, PO.Box. 522, 11000 Belgrade, Serbia, email: bee@ vinca.rs. 
$10^{\mathrm{TH}}$ INTERNATIONAL CONFERENCE ON SUSTAINABLE ENERGY AND ENVIRONMENTAL Protection (June 27 $7^{\mathrm{TH}}-30^{\mathrm{TH}}, 2017$, Bled, Slovenia), ENERgy MANAGEMENT AND POLICIES

M. Jovanović, V. Bakić, V. Turanjanin \& B. Vučićević: Multi-Criteria Approach to Sustainability Evaluate of District Heating System Scenarios in Case of Serbia

Public District Heating (PDH) systems in Serbia provide services for about 30\% of households on the territory of the Republic of Serbia. In 2008, consumption energy sources in these systems was about 7,108 GWh with the share of natural gas by $67 \%$, liquid fuels of $19 \%$ and coal $14 \%$ [1]. The share of thermal energy in final energy consumption for energy purposes in 2015. amounted to around $8.77 \%$ [2]. The total emissions of greenhouse gases that attributable to these systems amounted to about 2.0 million tonnes of $\mathrm{CO} 2 \mathrm{eq}$ per year.

Basic features of the PDH sector in Serbia are: a mix of fuel to be used largely depends on the terms of payment and liquidity of companies whose operating in the PDH sector; non-optimized distribution and delivery of heat in Serbia is one of the problems that affect on the inefficiency distribution and delivery of heat; losses in the distribution of thermal energy are also due to the poor state of the distribution network with a large water leaks and insufficient insulation; $48 \%$ of the distribution network is older than 20 years.

The Republic of Serbia has signed the Convention on Climate Change (UNFCC) in 2001 and ratified the Kyoto Protocol as non-Annex I country in 2008. As a candidate country for accession to the European Union (EU), Serbia assumed the obligation to apply European standards concerning the living environment and in the energy sector. Even $30 \%$ of legislation that needs to be adapted to EU standards is related to energy sector and environmental protection. It provides the opportunity to contribute to the reduction of GHG emissions, increase energy efficiency, gradually implement the principles of sustainable development, and reduce the local pollution of the environment.

According to the strategy in the energy sector [1], should be realized through implementation of the following measures:

a) Increasing energy efficiency of heat distribution systems. EU Directive on energy end-use efficiency and energy services adopted in 2006 has set a 9\% energy efficiency improvement target for the period $2008-2016$.

In addition, EU energy climate package "20-20-20" has defined an objective to achieve $20 \%$ energy efficiency increase by 2020 ;

b) Introducing contemporary technical solutions characterized by highly efficient performance;

c) Decreasing specific energy consumption by introducing heat consumption metering and payment for the energy actually consumed, together with energy efficient building design solutions;

d) Further substitution of coal and heavy oil with natural gas and renewable energy sources, primarily biomass. Nowdays, the energy scenarios have planned to fully utilize renewable energy technologies in municipal facilities [3]. 
$10^{\mathrm{TH}}$ INTERNATIONAL CONFERENCE ON SUSTAINABLE ENERGY AND ENVIRONMENTAL 121 Protection (June $27^{\mathrm{TH}}-30^{\mathrm{TH}}, 2017$, Bled, Slovenia), ENERgy MANAGEMENT AND POLICIES

M. Jovanović, V. Bakić, V. Turanjanin \& B. Vučićević: Multi-Criteria Approach to Sustainability Evaluate of District Heating System Scenarios in Case of Serbia

A techno-economic assessment of renewable energy sources (biomass) and their use for combined heat and power generation in Serbia was presented in [4], defining characteristics of Serbian renewable energy potentials and their utilization in decentralized energy generation.

The multi-criteria analysis was applied to estimate the sustainability of the various energy system options and scenarios [5] taking in account technical, economic, environmental and social impacts.

\section{The Energy Scenarios}

Since 2000, the consumption of fossil fuels in district heating systems has grown from year to year [6]. In this same period, there was a significant increase in the use of natural gas and to decrease the use of coal and oil derivatives. In 2000, the share of natural gas in the PDH system amounted to $56.7 \%$, while in 2015 it amounted to $74.7 \%$. The use of energy from renewable energy sources in district heating systems in Serbia is negligible so that it is only amounted to $0.3 \%$ in 2015 [2].

Strategic directions of the PDH sector are: continuous upgrading of existing heating systems, the expansion of existing district heating system, increasing the energy efficiency in the production, distribution and utilization of heat energy, the promotion of new energy systems which lead to decrease share of liquid fuel and coal; greater use of biomass and renewable energy sources, the use of municipal waste in the production of thermal energy and the combined production of heat and electricity.

Total heating surface area of buildings (residential, commercial and institutional) which is connected to the district heating system, in 2015 amounted to about $12.5 \%$ of the total floor building area of $315,000,000 \mathrm{~m}^{2}$, i.e. $39,375,000 \mathrm{~m}^{2}$ with an average specific heat energy consumption of $180 \mathrm{kWh} / \mathrm{m}^{2}$, and the surface of commercial and public buildings that are connected on the district heating system was approximately $19 \%$ of the total heated surface in the PDH sector, that is $7,481,250 \mathrm{~m}^{2}$.

Based on the available data [1], almost $14 \%$ of the total heating area use electricity for heating, primarily due to low electricity prices comparing in the price of final energy from liquid and gaseous fuels. In the Republic of Serbia, primary production of electricity obtained from lignite-fired power plant with total efficiency of energy transformation process of 0.33 and high transmition and distribution loses. This high residential electricity consumption for space heating is accompanied by high GHG emissions in energy generation sector.

Assessment of growth of housing in Serbia in 2050 is presented in [7]. Based on this assessment floor area buildings will grow 1.0-1.4\% in the period from 2015 to 2030, i.e. 1.4-1.7\% between 2030 and 2050, so that the estimated total building floor area in Serbia will amount to $329,660,000 \mathrm{~m}^{2}$ and $343,260,000 \mathrm{~m}^{2}$ in 2020 , respectively 2025 . If take 
$10^{\mathrm{TH}}$ INTERNATIONAL CONFERENCE ON SUSTAINABLE ENERGY AND ENVIRONMENTAL Protection (June 27 $7^{\mathrm{TH}}-30^{\mathrm{TH}}, 2017$, Bled, Slovenia), ENERgy MANAGEMENT AND POLICIES

M. Jovanović, V. Bakić, V. Turanjanin \& B. Vučićević: Multi-Criteria Approach to Sustainability Evaluate of District Heating System Scenarios in Case of Serbia

into account the price of energy policy and commitments of the Republic of Serbia in reducing emissions of greenhouse gases, to assume that by 2030, the proportion of the housing stock that is heated to a district heating system will increase from $12.5 \%$ in 2015 to $14.5 \%$ in 2020 and $16.5 \%$ in 2025 . While the heating surface area in the public and commercial sector, which is connected to the district heating system remained at $19 \%$ of the residential area to be heated by district heating system.

PDH sector analysis has done for base and three alternative scenarios. Base scenario (BAU- 'business and usual') relates to the assumption that thermal energy demand will increase by

$10 \%$ till 2020 and $15 \%$ till 2025 compared to 2015 , while the fuel mix will remain unchanged. In all the alternative scenarios, thermal energy demand from PDH sector remains the same as in the BAU scenario, while the fuel share is changed from one scenario to the other:

Table 1. Projection of energy consumption in PDH sector according to different scenarios

\begin{tabular}{|l|l|l|l|l|l|c|}
\hline Year/Scenario & $\begin{array}{l}\text { Total } \\
\text { energy } \\
{[\mathrm{TJ}]}\end{array}$ & $\begin{array}{l}\text { Liquid } \\
\text { fuel [\%] }\end{array}$ & $\begin{array}{l}\text { Solid } \\
\text { fuel [\%] }\end{array}$ & $\begin{array}{l}\text { Natural } \\
\text { gas [\%] }\end{array}$ & $\begin{array}{l}\text { RES } \\
{[\%]}\end{array}$ & $\begin{array}{l}\text { Heat } \\
\text { from } \\
\text { TPP } \\
{[\%]}\end{array}$ \\
\hline 2015 & 27,215 & 13 & 12 & 74.7 & 0.3 & 0 \\
\hline 2020 - BAU & 29,934 & 13 & 12 & 74.7 & 0.3 & 0 \\
\hline 2025 - BAU & 31,297 & 13 & 12 & 74.7 & 0.3 & 0 \\
\hline 2020 - I & 29,934 & 13 & 12 & 53 & 2.5 & 19.5 \\
\hline 2025 - I & 31,297 & 13 & 12 & 50 & 5 & 20 \\
\hline 2020 - II & 29,934 & 87.7 & 11.9 & 0 & 0.4 & 0 \\
\hline 2025 - II & 31,297 & 87.7 & 11.9 & 0 & 0.4 & 0 \\
\hline 2020 - III & 29,934 & 13 & 0 & 65 & 22 & 0 \\
\hline 2025 - III & 31,297 & 13 & 0 & 53 & 34 & 0 \\
\hline
\end{tabular}


$10^{\mathrm{TH}}$ INTERNATIONAL CONFERENCE ON SUSTAINABLE ENERGY AND ENVIRONMENTAL

Protection (June $27^{\mathrm{TH}}-30^{\mathrm{TH}}, 2017$, Bled, SLOVENiA), ENERgy MANAGEMENT AND

POLICIES

M. Jovanović, V. Bakić, V. Turanjanin \& B. Vučićević: Multi-Criteria Approach to

Sustainability Evaluate of District Heating System Scenarios in Case of Serbia

Table 2. Projection of GHG emissions according to different scenarios

\begin{tabular}{|c|c|c|c|c|c|c|c|c|}
\hline \multirow{2}{*}{$\begin{array}{l}\text { Year/Scenar } \\
\text { io }\end{array}$} & \multicolumn{8}{|c|}{$\begin{array}{l}\text { GHG } \\
\text { emission }[t]\end{array}$} \\
\hline & $\mathrm{CO}_{2}$ & $\mathrm{CH}_{4}$ & $\mathrm{~N}_{2} \mathrm{O}$ & $\mathrm{NO}_{\mathrm{x}}$ & $\begin{array}{c}\text { NMVO } \\
\mathrm{C}\end{array}$ & $\begin{array}{l}\mathrm{C} \\
\mathrm{O} \\
\end{array}$ & $\mathrm{SO}_{2}$ & $\mathrm{CO}_{2 \mathrm{eq}}$ \\
\hline 2015 & $\begin{array}{c}2,079,0 \\
00\end{array}$ & 34.22 & 8.71 & 4,735 & 136 & $\begin{array}{c}52 \\
5\end{array}$ & 7,620 & $\begin{array}{c}2,082,4 \\
51\end{array}$ \\
\hline $\begin{array}{ll}2020 & - \\
\text { BAU }\end{array}$ & $\begin{array}{c}2,286,6 \\
50 \\
\end{array}$ & 37.63 & 9.58 & 5,206 & 149 & $\begin{array}{c}57 \\
7 \\
\end{array}$ & 8,380 & $\begin{array}{c}2,290,4 \\
46 \\
\end{array}$ \\
\hline $\begin{array}{l}2025 \\
\text { BAU }\end{array}$ & $\begin{array}{c}2,391,3 \\
30\end{array}$ & 39.35 & $\begin{array}{c}10.0 \\
2\end{array}$ & 5,445 & 156 & $\begin{array}{c}60 \\
3 \\
\end{array}$ & 8,760 & $\begin{array}{c}2,395,3 \\
00\end{array}$ \\
\hline 2020 - I & $\begin{array}{c}1,811,2 \\
20 \\
\end{array}$ & 31.15 & 8.93 & 4,234 & 117 & $\begin{array}{c}44 \\
7 \\
\end{array}$ & 8,380 & $\begin{array}{c}1,814,6 \\
60 \\
\end{array}$ \\
\hline $2025-\mathrm{I}$ & $\begin{array}{c}1,831,7 \\
80\end{array}$ & 31.72 & 9.25 & 4,300 & 118 & $\begin{array}{c}45 \\
1\end{array}$ & 8,760 & $\begin{array}{c}1,835,3 \\
30\end{array}$ \\
\hline 2020 - II & $\begin{array}{c}3,660,5 \\
50\end{array}$ & $\begin{array}{c}132.1 \\
3\end{array}$ & $\begin{array}{c}30.7 \\
2\end{array}$ & 9,643 & 232 & $\begin{array}{c}71 \\
4\end{array}$ & $\begin{array}{c}30,73 \\
0\end{array}$ & $\begin{array}{c}3,673,0 \\
08\end{array}$ \\
\hline 2025 - II & $\begin{array}{c}3,827,6 \\
00\end{array}$ & $\begin{array}{c}138.1 \\
6\end{array}$ & $\begin{array}{c}32.1 \\
2\end{array}$ & $\begin{array}{c}10,08 \\
3\end{array}$ & 243 & $\begin{array}{c}74 \\
7\end{array}$ & $\begin{array}{c}32,12 \\
0\end{array}$ & $\begin{array}{c}3,840,6 \\
26\end{array}$ \\
\hline 2020 - III & $\begin{array}{c}1,747,0 \\
11\end{array}$ & 31.18 & 4.29 & 3,710 & 117 & $\begin{array}{c}44 \\
7\end{array}$ & 3,900 & $\begin{array}{c}1,748,0 \\
92\end{array}$ \\
\hline 2025 - III & $\begin{array}{c}1,556,9 \\
65\end{array}$ & 28.81 & 4.10 & 3,302 & 103 & $\begin{array}{c}39 \\
3\end{array}$ & 4,080 & $\begin{array}{c}1,558,9 \\
07\end{array}$ \\
\hline
\end{tabular}

- The first alternative scenario (I). The largest heating plant in Serbia, which supplies water for heating in winter and hot water in the summer period the city of Belgrade, is the Plant Belgrade's which annually consumes about of $300,200,000 \mathrm{~m}^{3}$ of natural gas, 45,836 tons of residential oil and about 9,600 t of pellets. At $60 \mathrm{~km}$ far from Belgrade there is TPP Obrenovac with installed capacity of 1,522 MW boilers. To reduce energy dependency rate and net imports, the construction of hot water pipeline from TPP Obrenovac to Belgrade that supplied Belgrade city with thermal energy by the year 2020 is considered. It was estimated that will be saved $150,000,000 \mathrm{~m}^{3}$ of natural gas per year.

- The second scenario (II). Second scenario represents a hypothetical case assuming that the total amount of natural gas is substituted by liquid fuel. This situation is almost happened when natural gas supplies are cut-off in winter 2008/2009 due to RussiaUkraine crisis.

- The third scenario (III). In 2015, the energy consumption of renewable energy (biomass) accounted for $0.3 \%$ of total energy consumption. In this scenario is considered to increase the use of renewable energy with a share of up to $34 \%$ (biomass, solid recovery fuels, solar and geothermal energy) in 2025, with a reduction of natural gas use and completely eliminating the use of coal. 
$124 \quad 10^{\mathrm{TH}}$ INTERNATIONAL CONFERENCE ON SUSTAINABLE ENERGY AND ENVIRONMENTAL Protection (June $27^{\mathrm{TH}}-30^{\mathrm{TH}}, 2017$, Bled, Slovenia), ENERgy Management AND POLICIES

M. Jovanović, V. Bakić, V. Turanjanin \& B. Vučićević: Multi-Criteria Approach to Sustainability Evaluate of District Heating System Scenarios in Case of Serbia

Table 1. presents projection of using fossil fuels and renewable energy sources in the PDH sector for different scenarios. Calculations of GHG emissions for 2015, 2020 and 2025 years were performed according to the IPCC methodology, with results were obtained and presented in Table 2.

\section{$3 \quad$ Selecting Criteria and Indicators for Assessing the Sustainability}

This paper describes different scenarios for thermal energy generated from DHS in Serbia. In the long term settings decision, sustainability of district heating system was estimated with methodology which used for support in decision making process. Selected criteria for assessing the sustainability of this complex energy system

Table 3. Economy sub-indicators

\begin{tabular}{|c|c|c|c|c|c|c|c|c|}
\hline \multirow[b]{2}{*}{ Scenario } & \multirow{2}{*}{ 苞 } & \multirow{2}{*}{ है } & $\mathbf{I}_{\mathrm{EC} 1}$ & $\mathbf{I}_{\mathrm{EC} 2}$ & $\mathbf{I}_{\mathrm{EC} 3}$ & $\mathrm{I}_{\mathrm{EC} 4}$ & $\mathbf{I}_{\mathrm{EC} 5}$ & $\mathbf{I}_{\mathrm{EC} 6}$ \\
\hline & & & $\mathrm{kWh} / \mathrm{m}^{2}$ & $\begin{array}{l}\text { EUR/ } \\
\text { hhmb. }\end{array}$ & $\mathrm{kWh} / \mathrm{m}^{2}$ & EUR & EUR & $\begin{array}{l}\mathrm{GWh} / \\
\mathrm{USD}\end{array}$ \\
\hline \multirow{3}{*}{$\begin{array}{l}\text { 'business- } \\
\text { as usual' }\end{array}$} & 2015 & 1 & 192.15 & 256.20 & 143.59 & $339,237,840$ & $453,946,200$ & 1.489 \\
\hline & 2020 & 2 & 174.09 & 221.42 & 130.11 & $379,384,376$ & $507,620,772$ & 1.423 \\
\hline & 2025 & 3 & 153.62 & 201.79 & 114.80 & $409,634,946$ & $548,135,658$ & 1.280 \\
\hline \multirow{2}{*}{$\begin{array}{c}\text { Scenario } \\
\text { I }\end{array}$} & 2020 & 4 & 174.09 & 119.98 & 37.76 & $110,108,294$ & $391,117,644$ & 1.423 \\
\hline & 2025 & 5 & 153.62 & 108.02 & 37.46 & $133,649,334$ & $435,028,300$ & 1.280 \\
\hline \multirow{2}{*}{$\begin{array}{c}\text { Scenario } \\
\text { II }\end{array}$} & 2020 & 6 & 174.09 & 373.47 & 152.64 & $445,062,710$ & $915,381,720$ & 1.423 \\
\hline & 2025 & 7 & 153.62 & 389.43 & 134.68 & $480,549,132$ & $1,131,073,580$ & 1.280 \\
\hline \multirow{2}{*}{$\begin{array}{c}\text { Scenario } \\
\text { III }\end{array}$} & 2020 & 8 & 174.09 & 271.61 & 16.98 & $49,500,402$ & $915,381,720$ & 1.423 \\
\hline & 2025 & 9 & 153.62 & 284.58 & 33.43 & $119,270,340$ & $1,131,073,580$ & 1.280 \\
\hline
\end{tabular}


$10^{\mathrm{TH}}$ INTERNATIONAL CONFERENCE ON SUSTAINABLE ENERGY AND ENVIRONMENTAL

Protection (June $27^{\mathrm{TH}}-30^{\mathrm{TH}}, 2017$, Bled, SLOVENiA), ENERGy MANAGEMENT AND POLICIES

M. Jovanović, V. Bakić, V. Turanjanin \& B. Vučićević: Multi-Criteria Approach to Sustainability Evaluate of District Heating System Scenarios in Case of Serbia

Table 4. Social sub-indicators

\begin{tabular}{|c|c|c|c|c|c|c|}
\hline \multirow{2}{*}{ Scenario } & \multirow{2}{*}{ 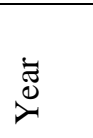 } & \multirow{2}{*}{ 苂 } & Iso1 & IsO2 & IsO3 & IsO4 \\
\hline & & & $\mathrm{kWh} / \mathrm{hh}$ & $\mathrm{kWh} / \mathrm{hh}$ & $\%$ & $\%$ \\
\hline \multirow{3}{*}{$\begin{array}{c}\text { 'business-as } \\
\text { usual' }\end{array}$} & 2015 & 1 & 12.30 & 0.045 & 9.2 & 67 \\
\hline & 2020 & 2 & 11.14 & 0.041 & 6.5 & 63 \\
\hline & 2025 & 3 & 9.83 & 0.037 & 4.9 & 58 \\
\hline \multirow{2}{*}{$\begin{array}{c}\text { Scenario } \\
\text { I }\end{array}$} & 2020 & 4 & 11.14 & 0.482 & 3.5 & 63 \\
\hline & 2025 & 5 & 9.83 & 0.850 & 2.6 & 58 \\
\hline \multirow{2}{*}{$\begin{array}{c}\text { Scenario } \\
\text { II }\end{array}$} & 2020 & 6 & 11.14 & 0.041 & 11.1 & 58 \\
\hline & 2025 & 7 & 9.83 & 0.037 & 9.4 & 52 \\
\hline \multirow{2}{*}{$\begin{array}{c}\text { Scenario } \\
\text { III }\end{array}$} & 2020 & 8 & 11.14 & 3.025 & 8.1 & 71 \\
\hline & 2025 & 9 & 9.83 & 4.128 & 6.9 & 72 \\
\hline
\end{tabular}

Table 5. Environmental sub-indicators

\begin{tabular}{|c|c|c|c|c|c|c|}
\hline \multirow{2}{*}{ Scenario } & \multirow[b]{2}{*}{ 苋 } & \multirow{2}{*}{ } & $\mathbf{I}_{\mathrm{EN1}}$ & $\mathrm{I}_{\mathrm{EN} 2}$ & $\mathbf{I}_{\mathrm{EN} 3}$ & $\mathbf{I}_{\mathrm{EN} 4}$ \\
\hline & & & $\mathrm{kg} / \mathrm{kWh}$ & $\mathrm{kg} / \mathrm{kWh}$ & $\mathrm{kg} / \mathrm{kWh}$ & $\mathrm{kg} / \mathrm{kWh}$ \\
\hline \multirow{3}{*}{$\begin{array}{l}\text { 'business- } \\
\text { as usual' }\end{array}$} & 2015 & 1 & 0.275 & $6.259 \mathrm{E}-04$ & $1.007 \mathrm{E}-03$ & $1.79306 \mathrm{E}-05$ \\
\hline & 2020 & 2 & 0.275 & $6.256 \mathrm{E}-04$ & $1.007 \mathrm{E}-03$ & $1.79266 \mathrm{E}-05$ \\
\hline & 2025 & 3 & 0.275 & $6.258 \mathrm{E}-04$ & $1.007 \mathrm{E}-03$ & $1.79308 \mathrm{E}-05$ \\
\hline \multirow{2}{*}{$\begin{array}{c}\text { Scenario } \\
\text { I }\end{array}$} & 2020 & 4 & 0.407 & $9.52 \mathrm{E}-04$ & $1.88 \mathrm{E}-03$ & $2.62517 \mathrm{E}-05$ \\
\hline & 2025 & 5 & 0.411 & $9.64 \mathrm{E}-04$ & $1.96 \mathrm{E}-03$ & $2.64245 \mathrm{E}-05$ \\
\hline \multirow{2}{*}{$\begin{array}{c}\text { Scenario } \\
\text { II }\end{array}$} & 2020 & 6 & 0.615 & $1.62 \mathrm{E}-03$ & $5.16 \mathrm{E}-03$ & $3.89758 \mathrm{E}-05$ \\
\hline & 2025 & 7 & 0.619 & $1.63 \mathrm{E}-03$ & $5.19 \mathrm{E}-03$ & $3.92499 \mathrm{E}-05$ \\
\hline \multirow{2}{*}{$\begin{array}{c}\text { Scenario } \\
\text { III }\end{array}$} & 2020 & 8 & 0.293 & $6.23 \mathrm{E}-04$ & $6.55 \mathrm{E}-04$ & $1.96031 \mathrm{E}-05$ \\
\hline & 2025 & 9 & 0.252 & $5.34 \mathrm{E}-04$ & $6.60 \mathrm{E}-04$ & $1.67009 \mathrm{E}-05$ \\
\hline
\end{tabular}

(DHS) reflect the following aspects: economic, social and environmental. Also, the criteria should be based on the time information and should present a strategic vision. This research analyse set of indicators for nine options which were defined in 'businessas usual' scenario as well as the in two alternative scenarios for 2020 and 2025 (Table 3$5)$.

Criteria indicate the quality of selected option within the limits of indicators. They should be designed with indicators which can be measured and which are applicable as the physical parameters. Indicators present the information that can be obtained in a suitable quantitative or qualitative manner. 
$10^{\mathrm{TH}}$ INTERNATIONAL CONFERENCE ON SUSTAINABLE ENERGY AND ENVIRONMENTAL Protection (June $27^{\mathrm{TH}}-30^{\mathrm{TH}}, 2017$, Bled, Slovenia), Energy Management AND POLICIES

M. Jovanović, V. Bakić, V. Turanjanin \& B. Vučićević: Multi-Criteria Approach to Sustainability Evaluate of District Heating System Scenarios in Case of Serbia

However, in this paper economic, social and environmental criteria are introduced in order to overcome the randomness in the sustainability assessment of an energy options for different scenarios. This paper shows that formed indicators numerical expressing the essential character of options. For each indicator, sets of sub-indicators are calculated. This means that indicators for certain criteria shows quantitative values and parameters (input date) of mathematical model for computing the sustainability index. In order to analyze the sustainability of the chosen options, in this paper six economic and four social and environmental sub-indicators are selected, defined and computed. In Tables 3-5 calculated values of sub-indicator sets within each of the analyzed indicators are presented. On the basis of a number of statistical data, data from the literature as well as the estimated values, the following sub-indicators values are calculated: a) Economic: specific thermal energy consumption per unit heating surface area $\mathrm{I}_{\mathrm{ECl}}\left(\mathrm{kWh} / \mathrm{m}^{2}\right)$; specific costs for home heating per household member, $\mathrm{I}_{\mathrm{EC} 2}(\mathrm{EUR} / \mathrm{hhmb})$; the maximum expected potential to reduce the consumption of heating energy from gas production per unit heating surface area, $\mathrm{I}_{\mathrm{EC} 3}\left(\mathrm{kWh} / \mathrm{m}^{2}\right)$; the maximum expected potential to reduce the cost for heating by reducing the amount of gas and introducing renewable energy sources, $\mathrm{I}_{\mathrm{EC} 4}(\mathrm{EUR})$; total costs required for the production of thermal energy, $\mathrm{I}_{\mathrm{EC} 5}(\mathrm{EUR})$; the thermal energy generation by GDP, $\mathrm{I}_{\mathrm{EC} 6}(\mathrm{GWh} / \mathrm{USD})$; b) Social: specific thermal energy consumption per household, $\mathrm{I}_{\mathrm{SO} 1}(\mathrm{kWh} / \mathrm{hh})$; usage of renewable energies per household, $\mathrm{I}_{\mathrm{SO} 2}(\mathrm{kWh} / \mathrm{hh})$; share of space heating cost in household revenue, $\mathrm{I}_{\mathrm{SO} 3}(\%)$; energy supply security, $\mathrm{I}_{\mathrm{SO} 4}(\%)$; c) Environmental: carbon-dioxide emissions per energy production, $\mathrm{I}_{\mathrm{EN} 1}\left(\mathrm{kgCO}_{2} / \mathrm{kWh}\right)$; sulfur-dioxide emissions per energy production, $\mathrm{I}_{\mathrm{EN} 2}$ $\left(\mathrm{kgSO}_{2} / \mathrm{kWh}\right)$; nitrogen-oxide emissions per energy production, $\mathrm{I}_{\mathrm{EN} 3}(\mathrm{kgNOx} / \mathrm{kWh})$; emission of non-methane volatile organic compounds per energy production, $\mathrm{I}_{\mathrm{EN} 4}(\mathrm{~kg} /$ $\mathrm{kWh}),[5-15]$.

\section{Determination Index of Sustainability and Analuze Options for Scenarious Until 2025}

For estimating the sustainability of selected options and calculating index of sustainability (IS), ASPID (Analyse and Synthesis Parameters under Information Deficiency) multi-criteria method is used. This procedure is based on 'the fuzzy set synthesis technique', which represents the mathematical system to support the decision process and it useful for treating vague information and uncertainty.

Index of sustainability use as an evaluative tool, most popular and quantitative tool (generally) that analyses changes, monitor and measure of sustainable development and communicate progress towards sustainable development. Its purpose is to show how well a system is working towards the defined goals. Equal 1 show how to get IS on the second level of calculation which includes pre-defined constraints that represent non-numerical information about interrelation between criteria. Also, synthesis function for index sustainability calculation is used. 
M. Jovanović, V. Bakić, V. Turanjanin \& B. Vučićević: Multi-Criteria Approach to Sustainability Evaluate of District Heating System Scenarios in Case of Serbia

$$
\begin{aligned}
\overline{Q(q ; I)} & =\frac{1}{N(I ; m, n)} \sum_{s=1}^{N(I ; m, n)} Q\left(q ; w^{(s)}\right), \\
w^{(s)} & \in W(I ; m, n)
\end{aligned}
$$

This study has proposed and analysed three cases when economic, social and environmental indicators have important [16-18]. Figure 1 shows ranking list of options for Case 1 where economic indicator and sub-indicators of specific costs for home heating have priority. At the top of the priority list the most sustainable Options 3 and 5 are placed. Depending on the weight assigned to criteria for Case 2, social indicator and subindicator of share of space heating cost in household revenue, Option 3 and Option 9 have highest index of sustainability, Figure 2. Given equal weighting of economic and social criteria and priority to environmental dimension (sub-indicators of sulphur-dioxide emissions and nitrogen-oxide emissions per energy production), for Case 3 in Figure 3, the best level of sustainability have Option 3 and Option 9 as in previous case.

\section{CASE 1}

$$
\mathrm{I}_{\mathrm{EC}}>\mathrm{I}_{\mathrm{SO}}=\mathrm{I}_{\mathrm{EN}}
$$

$\mathrm{I}_{\mathrm{EC}}\left(\mathrm{I}_{\mathrm{EC} 2}>\mathrm{I}_{\mathrm{EC} 5}>\mathrm{I}_{\mathrm{EC} 4}=\mathrm{I}_{\mathrm{EC} 3}>\mathrm{I}_{\mathrm{EC} 6}=\mathrm{I}_{\mathrm{EC} 1}\right)>\mathrm{I}_{\mathrm{SO}}\left(\mathrm{I}_{\mathrm{SO} 1}=\mathrm{I}_{\mathrm{SO} 2}>\mathrm{I}_{\mathrm{SO} 3}>\mathrm{I}_{\mathrm{SO} 4}\right)=\mathrm{I}_{\mathrm{EN}}\left(\mathrm{I}_{\mathrm{EN} 1}>\mathrm{I}_{\mathrm{EN} 2}=\right.$ $\left.\mathrm{I}_{\mathrm{EN} 3}>\mathrm{I}_{\mathrm{EN} 4}\right)$

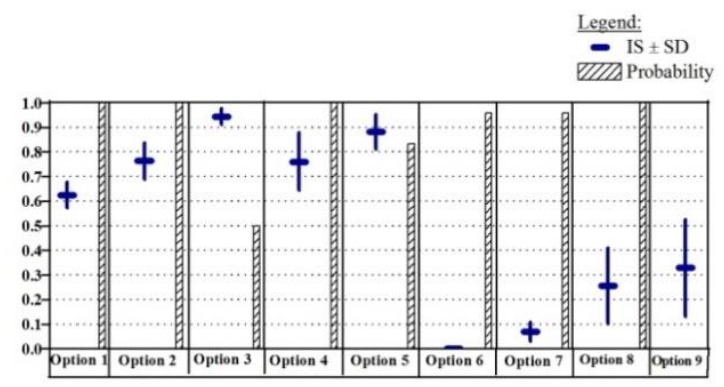

Figure 1. Priority list of options for Case 1

\section{CASE 2}

$$
\mathrm{I}_{\mathrm{SO}}>\mathrm{I}_{\mathrm{EC}}=\mathrm{I}_{\mathrm{EN}}
$$

$\mathrm{I}_{\mathrm{SO}}\left(\mathrm{I}_{\mathrm{SO} 3}>\mathrm{I}_{\mathrm{SO} 2}=\mathrm{I}_{\mathrm{SO} 1}>\mathrm{I}_{\mathrm{SO} 4}\right)>\mathrm{I}_{\mathrm{EC}}\left(\mathrm{I}_{\mathrm{EC} 3}>\mathrm{I}_{\mathrm{EC} 2}>\mathrm{I}_{\mathrm{EC} 1}=\mathrm{I}_{\mathrm{EC} 6}>\mathrm{I}_{\mathrm{EC} 4}=\mathrm{I}_{\mathrm{EC} 5}\right)=\mathrm{I}_{\mathrm{EN}}\left(\mathrm{I}_{\mathrm{EN} 1}=\mathrm{I}_{\mathrm{EN} 4}>\right.$ $\left.\mathrm{I}_{\mathrm{EN} 3}>\mathrm{I}_{\mathrm{EN} 2}\right)$ 
$128 \quad 10^{\mathrm{TH}}$ INTERNATIONAL CONFERENCE ON SUSTAINABLE ENERGY AND ENVIRONMENTAL Protection (June $27^{\mathrm{TH}}-30^{\mathrm{TH}}, 2017$, Bled, Slovenia), ENERgy Management AND POLICIES

M. Jovanović, V. Bakić, V. Turanjanin \& B. Vučićević: Multi-Criteria Approach to Sustainability Evaluate of District Heating System Scenarios in Case of Serbia

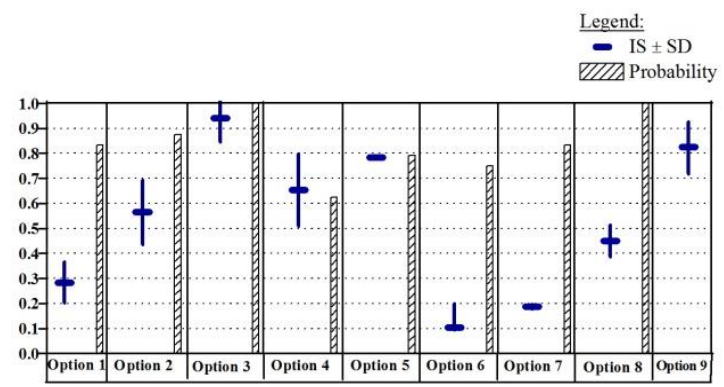

Figure 2. Priority list of options for Case 2

\section{CASE 3}

$\mathrm{I}_{\mathrm{EN}}>\mathrm{I}_{\mathrm{SO}}=\mathrm{I}_{\mathrm{EC}}$

$\mathrm{I}_{\mathrm{EN}}\left(\mathrm{I}_{\mathrm{EN} 2}=\mathrm{I}_{\mathrm{EN} 3}>\mathrm{I}_{\mathrm{EN} 1}>\mathrm{I}_{\mathrm{EN} 4}\right)>\mathrm{I}_{\mathrm{SO}}\left(\mathrm{I}_{\mathrm{SO} 2}>\mathrm{I}_{\mathrm{SO} 1}>\mathrm{I}_{\mathrm{SO} 3}=\mathrm{I}_{\mathrm{SO} 4}\right)=\mathrm{I}_{\mathrm{EC}}\left(\mathrm{I}_{\mathrm{EC} 4}=\mathrm{I}_{\mathrm{EC} 3}>\mathrm{I}_{\mathrm{EC} 1}>\mathrm{I}_{\mathrm{EC} 2}=\mathrm{I}_{\mathrm{EC} 5}=\right.$ IEC6)

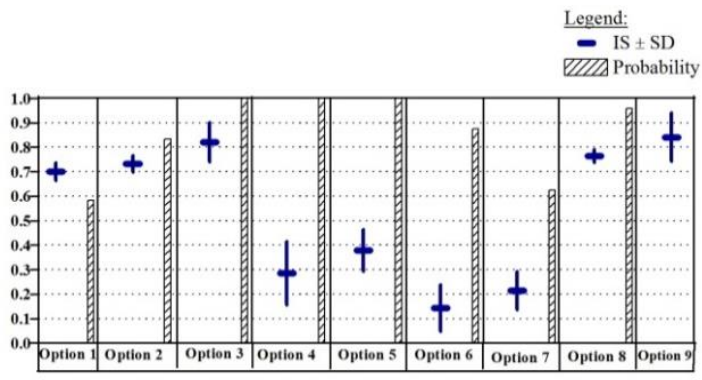

Figure 3. Priority list of options for Case 3

\section{$5 \quad$ Conclusion}

Gas is the main source for the production of thermal energy in RS but because everpresent possibility of gas crisis, the lack of domestic coal due to possible floods and environmental pollution and unsustainable price of fuel oil, alternative scenarios that were analyzed in this paper provide renewable sources (SRF, biomass, solar and geothermal) to thermal energy production.

To assess the sustainable development of district heating systems, as a complex energy system, to 2025 in the Republic of Serbia, the paper considers nine options for several scenarios. The first option is to use 'business-as-usual' scenario that examines the consequence of continuing current trends in heat energy production technology. The data show that the heat energy produced in district heating systems in the RS in 2015 obtained from the gas of $75 \%$ and residual fuel oil of $13 \%$. It is noted that in relation to 'business- 
$10^{\mathrm{TH}}$ INTERNATIONAL CONFERENCE ON SUSTAINABLE ENERGY AND ENVIRONMENTAL 129 Protection (June $27^{\mathrm{TH}}-30^{\mathrm{TH}}, 2017$, Bled, Slovenia), ENERgy MANAGEMENT AND POLICIES

M. Jovanović, V. Bakić, V. Turanjanin \& B. Vučićević: Multi-Criteria Approach to Sustainability Evaluate of District Heating System Scenarios in Case of Serbia

as-usual' scenario, share of gas decreases to $22 \%$ or $10 \%$ in Scenario I and Scenario III. Scenario II does not predict gas consumption and the largest part of thermal energy production comes from the residual fuel oil. Reduction of gas consumption is replaced by the thermal energy from the thermal power plant (Scenario 1) or introduction of RES in Scenario III.

The results of this research illustrate use of multi-criteria method and promote the quality of evaluation the most sustainable energy options according to different aspects of sustainability. For all of cases option 3 is perfect ranking option ('business-as-usual' scenario for 2025), and for Case 3 and Case 2 Option 9 (scenario III of 2025) has highest sustainability. Also, for all cases, Option 6 and 7 (scenario II for 2020 and 2025) have very low sustainability and are placed on the bottom of the priority list. The established methodology can help policy makers in finding future decisions in selection of district heating system.

\section{References}

[1] Strategy of energy sector development in the Republic of Serbia until 2015, Termotehnika, Vol. 31, No.1-2, pp. 13-70, 2005 (in Serbian).

[2] Federal Statistical Office, Energy balance of the Republic of Serbia for 2015, No.622, Belgrade 2017.

[3] T. Tomic, B. Cosic and D. R. Schneider, Influence of legislative conditioned changes in waste management on economic viability of MSW-fuelled district heating system -case study, Thermal Science, Vol.20, No.4., pp. 1105-1120, 2016.

[4] B. Glavonjic, L. Oblak, Consuption of woody biomass in industry, commercial and public facilities in Serbia, Present State and Possible Contribution to the Share of Renewable Sources in Final Energy Consumption, Thermal Science Vol 16., No.1., pp. 7-19, 2012.

[5] J.J. Wang, Y.Y. Jing, C.F. Zhang, J.H. Zhao, Review on multi-criteria decision analysis aid in sustainable energy decision making, Renewable and Sustainable Energy Reviews, Vol. 13, pp. 2263-2278, 2009.

[6] P. Stefanović, V. Bakić, Z. Marković, M. Jovanović, V. Turanjanin, D. Cvetinović, et all, Emission of greenhouse gases in PE "Toplane" in the cities of the Republic of Serbia in the period 1990 to 2008. Internal report NIV-ITE 2010; No. 445 (in Serbian).

[7] The typology of the residential building stock in Serbia and modeling its low-carbon transformation Serbia, Report of project: Support for Low-Emission Development in South Eastern Europe (SLED), December 2015.

[8] Fundamentals of balancing energy building, Serbian Chamber of Engineers, Belgrade 2012 (in Serbian)

[9] The Official Gazette of the City of Belgrade, No. 56, 30 september 2015 (in Serbian)

[10] http://ec.europa.eu/eurostat/statistics-explained/index.php/File:Halfyearly_gas_prices_(EUR).png

[11] http://www.worldbank.org/en/country/serbia/overview

[12] http://www.tradingeconomics.com/serbia/gdp

[13] http://www.deagel.com/country/Serbia_c0178.aspx

[14] Republic Institute for Statistics, statistics of employment and earnings, No.15 - year LXVII, 25/01/2017 (in Serbian) 
$130 \quad 10^{\mathrm{TH}}$ INTERNATIONAL CONFERENCE ON SUSTAINABLE ENERGY AND ENVIRONMENTAL

Protection (June 27 $7^{\mathrm{TH}}-30^{\mathrm{TH}}, 2017$, Bled, Slovenia), ENERgy MANAGEMENT AND POLICIES

M. Jovanović, V. Bakić, V. Turanjanin \& B. Vučićević: Multi-Criteria Approach to Sustainability Evaluate of District Heating System Scenarios in Case of Serbia

[15] D. Cvetinovic, P. Stefanovic, Z. Markovic, V. Bakic, V. Turanjanin, M. Jovanovic, B. Vucicevic, GHG (Greenhouse Gases) emission inventory and mitigation measures for public district heating plants in the Republic of Serbia, Energy, Vol. 57, pp. 788-795, 2013.

[16] N. Afgan, M. Carvalho, M. Jovanović Biomass-fired power plant: the sustainability option, International Journal of Sustainable Energy, Vol.26, No.4, pp.179-193, 2007.

[17] N. Afgan, Quality, sustainability and indicators of energy systems, Lisbon, Portugal: Instituto Superior Tecnico, 2003.

[18] P. Škobalj, M. Kijevčanin, M. Jovanović, N. Afgan, Milić D. Erić, Energy indicators impact in multicriteria sustainability analyse of thermal power plant unit, Thermal Science, Vol.21, No.2, pp1143-1151, 2016. 
$10^{\mathrm{TH}}$ InTERnational CONFERENCE ON Sustainable ENERgy AND ENVIRONMENTAL Protection (June $27^{\mathrm{TH}}-30^{\mathrm{TH}}$, 2017, Bled, SLOVENIA), ENERGy MANAGEMENT AND Policies

J. Krope, A.Ghani Olabi, D. Goričanec \& S. Božičnik

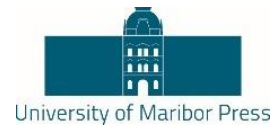

\title{
Policies and Measures for Sustainable and Energy Efficient Urban Freight Transport
}

\author{
TOMISLAV LETNIK, GIUSEPPE LUPPINO, ANDREA BARDI \& STANE BOZICNIK
}

\begin{abstract}
Sustainable and energy efficient transport of passengers and goods has become a major concern of policy makers worldwide. This paper aims to investigate the existence of policies and measures for sustainable urban freight planning in European cities. A methodology for a comprehensive mapping and benchmarking of policy documents and measures has been developed and applied to a panel of more than 129 European cities. The analysis shows an extremely heterogeneous situation concerning logistics and mobility planning documents in Europe. Logistics is in most cases included into sustainable transport planning whereby there are very few measures directly dedicated to the energy savings. On the other hand, several measures have indirect impact on energy consumption, due to the optimisation of transport flows (e.g. fuel savings, because of shorter transport distances), the introduction of clean vehicles for logistics operations (e.g. electric mobility) or modal shift (e.g. use of transport means with lower energy impact).
\end{abstract}

Keywords: • transport $\bullet$ sustainability $\bullet$ energy efficiency $\bullet$ policy measures

- freight transport •

CORRESPONDENCE ADDRESS: Tomislav Letnik, Senior Lecturer, University of Maribor, Faculty of Civil Engineering, Transportation Engineering and Architecture, Smetanova 17, 2000 Maribor, Slovenia, e-mail: tomislav.letnik@um.si. Giuseppe Luppino, Project Manager, Institue for Transport and Logistics - ITL, via dei Mille 21, 40121 Bologna, Italy, e-mail: giuseppe.luppino@regione.emilia-romagna.it. Andrea Bardi, General Manager, Institue for Transport and Logistics - ITL, via dei Mille 21, 40121 Bologna, Italy, e-mail: andrea.bardi@fondazioneitl.org. Stane Bozicnik, Ph.D., Associate Professor, University of Maribor, Faculty of Civil Engineering, Transportation Engineering and Architecture, Smetanova 17, 2000 Maribor, Slovenia, e-mail: stane.bozicnik@um.si. 
$10^{\mathrm{TH}}$ INTERNATIONAL CONFERENCE ON SUSTAINABLE ENERGY AND ENVIRONMENTAL Protection (June $27^{\mathrm{TH}}-30^{\mathrm{TH}}, 2017$, Bled, Slovenia), ENERGy MANAGEMENT AND POLICIES

T. Letnik, G. Luppino, A. Bardi \& S. Bozicnik: Policies and Measures for Sustainable and Energy Efficient Urban Freight Transport

Transport is the largest energy-consuming sector in the EU-28, with a $33 \%$ of the share of total final energy consumption [1]. The European Commission has set the ambitious goal of CO2-free city logistics by 2030 [2]. This does not only call for public policy actions, but for a shift in the paradigm of policies. Over $80 \%$ of the European population will live in cities by 2050 [3], therefore urban freight issues need to be tackled not only from the perspective of the city logistics but also from the perspective of the "Functional Urban Areas" (FUAs).

FUA takes into consideration transport in the (and between) urban centres and the pending surrounding urban territories, because of their close regional economic relations. For achieving sustainable territorial and economic development FUAs are put in the political focus of the EU.

To solve the problems of urban mobility holistically, European Commission launched the concept called "Sustainable Urban Mobility Plan" (SUMP). The concept refers to an innovative planning approach, which structures the steps of mobility planning in urban contexts and guides authorities towards a more comprehensive and sustainable approach in developing their mobility plans [4]. According to the European Commission [5], a Sustainable Urban Mobility Plan is a strategic plan designed to satisfy the mobility needs of people and businesses in cities and their surroundings for a better quality of life. It builds on existing planning practices and takes due consideration of integration, participation, and evaluation principles. The ELTIS guidelines developed by the European Commission described in detail the SUMP concept and its development phases [4].

With the new concepts of European Commission also freight mobility becomes an important issue. In the existing concepts, freight transport is addressed only partially, and for that reason, the idea of Sustainable Urban Logistics Plans (SULP) has been launched [6]. SULP can stand as a separate document or can be considered as a part of the existing SUMP.

In the period before this initiatives, cities have adopted diverse documents covering the urban freight problems. Logistics/mobility planning issues can be found in different cities in different documents on different levels. The main aim of this paper is to review existing documents and measures in a panel of European cities to understand the level of implementation of sustainable mobility/logistics measures, which have an enormous impact on energy consumption and $\mathrm{CO} 2$ emissions.

\section{$2 \quad$ Methodology for the Analysis}

The analysis is focusing on city mobility/logistics documents of the chosen European cities in order to find out their main contents, governances and development processes. 
T. Letnik, G. Luppino, A. Bardi \& S. Bozicnik: Policies and Measures for Sustainable and Energy Efficient Urban Freight Transport

For the analysis of the state of the art, the bottom-up approach was used. Based on that a categorization of documents and types of measures was performed.

The methodological concept is shown in the figure (1) below.

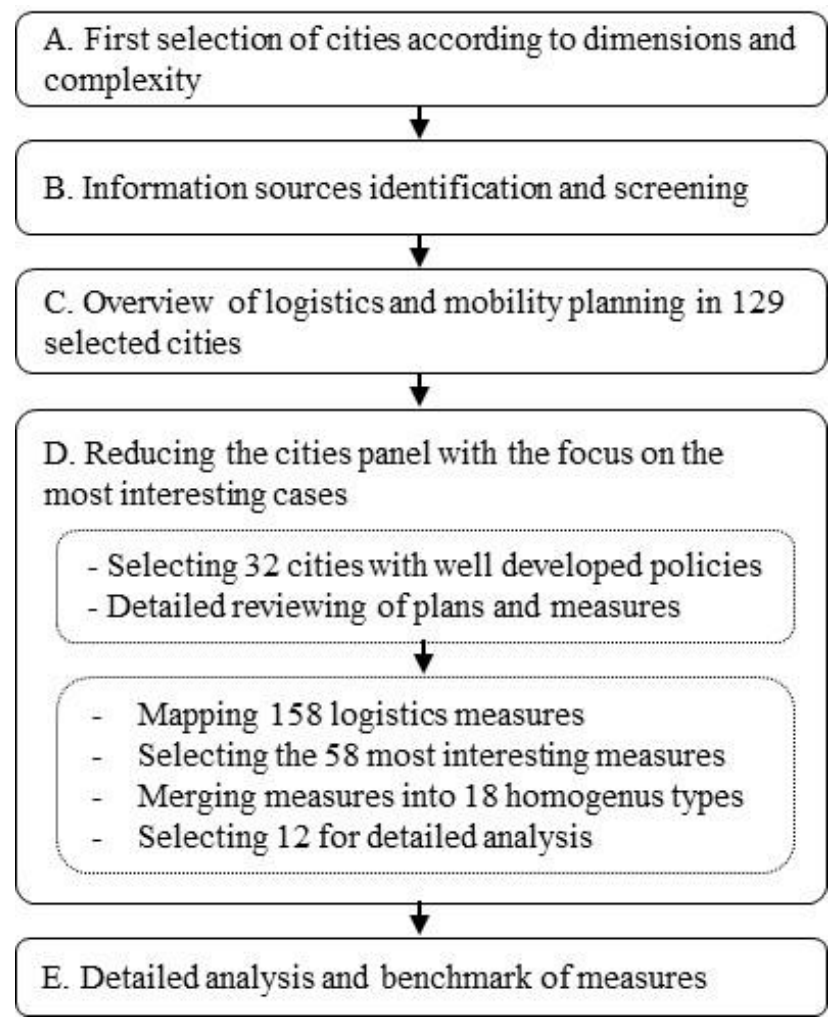

Figure 1. The methodological steps

In the first step $(A)$, cities have been selected according to their dimension and characteristics. The main aim was to take into consideration as a diverse sample of cities as possible (continental cities, cities with rivers where inland navigation is possible and cities at the coast). In addition to that, the focus on the analysis was not only in city centres but to a wider territory aspect of Functional Urban Areas (FUAs), which consists of the city core and its commuting zone [7]. Considering that aspects 129 cities (shown on the map/figure 2 below) have been identified and selected for the analysis. 
134 10 $10^{\mathrm{TH}}$ INTERNATIONAL CONFERENCE ON SUSTAINABLE ENERGY AND ENVIRONMENTAL Protection (June $27^{\mathrm{TH}}-30^{\mathrm{TH}}, 2017$, Bled, Slovenia), Energy Management AND POLICIES

T. Letnik, G. Luppino, A. Bardi \& S. Bozicnik: Policies and Measures for Sustainable and Energy Efficient Urban Freight Transport

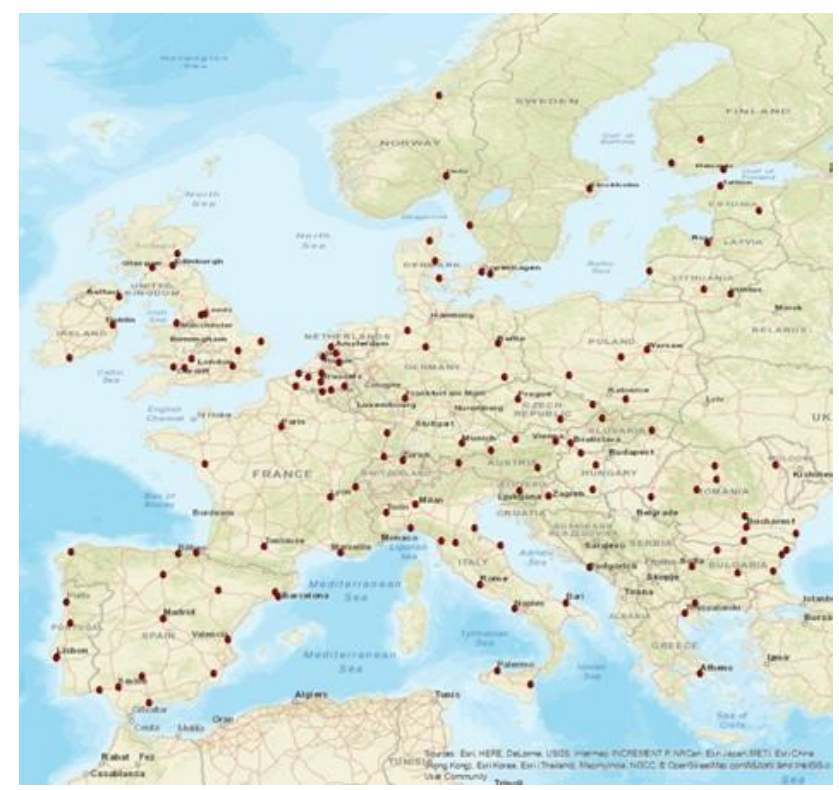

Figure 2. The panel of cities

After identification of cities, the main aim was to identify information sources $(B)$ of planning documents containing logistics topics (policies, measures). This step is very difficult and time-consuming because documents containing this kind of information are very versatile and fragmented.

To map and analyse logistics planning and low carbon mobility measures, two types of sources have been selected:

- the institutional websites of the selected cities, as the primary source of information concerning their logistics planning activities (for the sake of brevity web page addresses are not included in the list of references);

- thematic websites and documents concerning SUMPs, urban logistics and SULPs, among which: ELTIS [8], 2MOVE2 [9], ADVANCE [10], BUMP [11], CH4LLENGE [12], CIVINET [13], DO THE RIGHT MIX [14], DYN@MO [15], ECOMOBILITY SHIFT [16], ENDURANCE [17], PUMAS [18], SOLUTIONS [19] and TIDE [20].

Based on the identified information sources the mobility planning documents were mapped and preliminarily reviewed $(C)$. 
T. Letnik, G. Luppino, A. Bardi \& S. Bozicnik: Policies and Measures for Sustainable and Energy Efficient Urban Freight Transport

In this process, we identified the existence of:

- SUMP or mobility planning documents,

- documents that include logistics measures (specific logistics actions) in mobility planning and

- the presence of a logistics plan (the comprehensive process of planning logistics and related measures at urban level).

In the next phase $(D)$ the panel of cities was reduced to 32 cities with well-developed logistics planning documents and measures. In these cities, we identified in total 158 measures. These measures were reviewed in detail to identify 58 measures which could represent best practices and for which enough data were available. For an in-depth understanding of identified measures various sources of information has been used: Stathopoulos et al. [21], Browne et al. [22], Giuliano et al. [23], BESTFACT [24] and CITYLOG [25].

The 58 measures were finally grouped into 12 measures typologies that have been selected for detailed analysis. The main driver for final selection of measures was to include types of measures that could be applied not only to the city centre but also at wider City / FUA level.

Finally, the measure types were qualitatively benchmarked with reference to:

- The category of measures type.

- The territorial level of applicability: City centre, Specific city areas in the FUA, overall City / FUA.

- The investment and operational costs.

\section{Sustainable Mobility Planning in European Cities}

The diversity of identified documents required a categorization of cases which could allow the benchmarking of the city planning cases. This resulted in 5 categories of cities:

- SUMPs without city logistics measures;

- Mobility Plan with city logistics measures;

- SUMP with city logistics measures;

- Logistics plans;

- SULPs.

From the panel of 129 cities, $29(22,5 \%)$ did not fall in any of the identified categories. This does not mean that those cities are not facing mobility issues or do not have developed mobility plans. It means they don't have SUMPs and they don't have specific logistics measures in the adopted documents. 
$136 \quad 10^{\mathrm{TH}}$ INTERNATIONAL CONFERENCE ON SUSTAINABLE ENERGY AND ENVIRONMENTAL Protection (June $27^{\mathrm{TH}}-30^{\mathrm{TH}}, 2017$, Bled, Slovenia), ENERgy Management AND POLICIES

T. Letnik, G. Luppino, A. Bardi \& S. Bozicnik: Policies and Measures for Sustainable and Energy Efficient Urban Freight Transport

Among the rest of cities (100 cities), 7 cities have SUMPs without city logistics measures, 46 cities have mobility plan with city logistics measures, 38 cities have SUMPs with logistics measures, 4 cities have logistics plans and 9 cities have SULPs. The results are graphically presented in Figure 3 below.

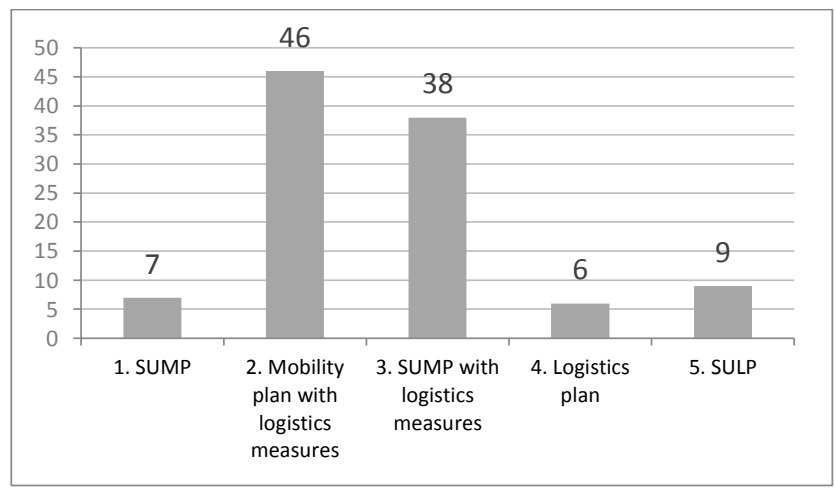

Figure 3. Frequency of planning documents by category in the chosen panel of cities

With specific reference to SULPs, it is important to mention that all the cities in the figure above were involved in the ENCLOSE EU project, which was devoted to the development of SULPs in the cities participating in the Enclose project. Therefore, SULP concept can be considered as a specific project concept.

On the other hand, the SUMPs concept is quite present in the panel: 45 cities have developed SUMPs, of which 38 also includes logistics. It is worthwhile to report that about $15.6 \%$ of the cities which have developed SUMPs have not included logistics.

\section{$4 \quad$ Low Carbon and Energy Efficient Measures in Selected European Cities}

As indicated in the methodological part, we have mapped urban logistics measures in 32 European cities (Table 1). These cities were selected based on a criterion of geographic coverage at European level and on the existence of well-developed policies and measures. 
$10^{\mathrm{TH}}$ INTERNATIONAL CONFERENCE ON SUSTAINABLE ENERGY AND ENVIRONMENTAL

T. Letnik, G. Luppino, A. Bardi \& S. Bozicnik: Policies and Measures for Sustainable and Energy Efficient Urban Freight Transport

Table 1: The panel of the cities for the low carbon urban logistics measures analysis

\begin{tabular}{|l|c|}
\hline Country & Cities \\
\hline Austria & Vienna \\
\hline Belgium & Ghent, Brussels \\
\hline Bulgaria & Burgas, Balchik \\
\hline Croatia & Zagreb \\
\hline Czech Republic & Brno \\
\hline Denmark & Aalborg \\
\hline Finland & Helsinki \\
\hline France & Toulouse, Lyon, Paris \\
\hline Germany & Bremen, Berlin \\
\hline Greece & Serres \\
\hline Hungary & Pécs \\
\hline Italy & Turin, Lucca \\
\hline The Netherlands & s'Hertogenbosch, Utrecht, \\
\hline Norway & Trondheim \\
\hline Poland & Kraków \\
\hline Portugal & Almada \\
\hline Romania & Alba Giulia \\
\hline Spain & Burgos, Barcelona \\
\hline Sweden & Malmö, Stockholm \\
\hline $\begin{array}{l}\text { United } \\
\text { Kingdom }\end{array}$ & Dundee, Norwich, London \\
\hline
\end{tabular}

Initially, 158 measures have been identified in selected cities and finally grouped into the following 12 types of measures:

1) Off-street loading bays; The measure focuses on developing loading and unloading areas which are located outside the street space. The objective is to make public spaces less congested and more liveable. The measure is implemented or planned in Vienna, Paris, Barcelona, Alborg and Kraków.

2) Cargo bikes; Cargo bikes can be used for light deliveries (up to $250 \mathrm{~kg}$ ) and short distances. The scope of applications of such type of measure becomes even broader when combined with electric drives. The measure is implemented or planned in Vienna, Paris, Lucca, Turin, Ghent, Graz and Bucharest.

3) Clean fuels/vehicles mobility scheme; The main objective of the measure is to foster sustainable and low carbon delivery services in both urban and metropolitan areas. This measure can find different types of applications (Low Emission Zones, subsidies to buy clean vehicles, delivery of alternative fuels infrastructures etc.). It can also represent part of an energy and environmental policy. The measure is implemented or planned in Vienna, Utrecht, Turin, Lyon, Bremen, Berlin, Trondheim, Burgos and Alborg. 
$138 \quad 10^{\mathrm{TH}}$ INTERNATIONAL CONFERENCE ON SUSTAINABLE ENERGY AND ENVIRONMENTAL Protection (June $27^{\mathrm{TH}}-30^{\mathrm{TH}}, 2017$, Bled, Slovenia), ENERgy Management AND POLICIES

T. Letnik, G. Luppino, A. Bardi \& S. Bozicnik: Policies and Measures for Sustainable and Energy Efficient Urban Freight Transport

4) Spatial planning for logistics; The measure focuses on identifying and "reserving" land for logistics purposes. The goal is to increase the efficiency of freight transport in the concerned territorial context. The measure is implemented or planned in Brussels and Paris.

5) Freight routes; This measure focuses on regulating freight vehicles routes. The main objective is improving the efficiency of freight deliveries by providing routes (also in real time) and signage for freight vehicles to access transport nodes and industrial areas. The measure is implemented or planned in Brussels, Amsterdam, Helsinki, Serres, Malmö and Toulouse.

6) Truck tolling/charging; The measure aims at applying tolling/charging schemes for freight vehicles on the certain territorial area. Tolls and charges can be levied according to the distance travelled, the type of vehicle (e.g. truckload, emission class) or they can be time-based. The main aims of the measure are to internalise freight transport external costs and have revenues to pay for the road infrastructure maintenance and/or improvements. The measure is implemented or planned in Vienna and Brussels.

7) Delivery and servicing plans; The measures aim to proactively manage deliveries and servicing trips, promote safe and legal loading, select logistic providers committed to best practices. The main purpose is to optimise fleets and freight demand and reduce the number of trips. The measure is implemented or planned in Brussels, London, Zagreb, Serres, Trondheim and Alborg.

8) Mobile depots; Mobile depots are mobile warehouses serving specific city areas. Last mile deliveries are operated by environmentally friendly transport vehicles, such as cargo bikes, trolleys or on foot. More precisely, a trailer is loaded as a depot outside the city and it is moved to a central parking area within the city centre. In the evening, the trailer goes back to the logistics operator's main depot (e.g. together with the cargo bikes or trolleys). The measure is implemented or planned in Brussels and Turin.

9) Off-peak deliveries; This measure focuses on shifting delivery schedules out of peak hours or at night. The measure is focussed on the benefit for transport operators deriving from the fact that delivering at night is cheaper because it is faster (e.g. less congestion, more space for unloading, fewer fines). The measure is implemented or planned in Brussels, Barcelona, Alba Julia and Serres.

10) By boat logistics; This measure provides a solution for urban delivery chains, focusing on the use of waterways as an energy efficient alternative to road transport. The main purpose is to optimise the multimodal transport network and reduce the congestion and pressure of freight vehicles on the urban road infrastructure. The measure is implemented or planned in Balchik, Burgas, Paris, Utrecht and Amsterdam.

11) Urban Distribution Centres; Urban Distribution/Consolidation Centres (UDC/UCC) are logistics facilities located in the proximity of the receivers that they serve. Goods are consolidated at the logistics facilities and transported to their final destinations with environmentally sustainable transport solutions (e.g. clean fuelled vehicles or bikes). The measure is implemented or planned in Brno, Toulouse, Paris, Barcelona, Lucca, Almada, Dundee, Norwich, Serres, s’Hertogenbosc, Kraków, Alba Julia, Burgos and London. 
T. Letnik, G. Luppino, A. Bardi \& S. Bozicnik: Policies and Measures for Sustainable and Energy Efficient Urban Freight Transport

12) Coordination of urban freight rules; This type of measure has the purpose of coordinating or harmonising freight rules at the city or FUA level. It responds to the need of businesses to have clear and homogenous regulations which are not different or conflicting within the districts of the same City/FUA. The measure promotes horizontal governance among authorities of the same FUA and the coordination of city logistics regulations. The measure is implemented or planned in Toulouse, Burgos and Pécs.

13)

In the final step, all these measures have been categorised to one or more of the following categories:

- regulation,

- technology,

- infrastructures,

- services,

- industrial/economic,

- urban planning and

- energy.

Table 2: Overview and benchmark of selected logistics measures

\begin{tabular}{|c|c|c|c|c|c|c|c|c|c|c|c|c|}
\hline $\begin{array}{l}\text { Parameters of } \\
\text { assessment }\end{array}$ & 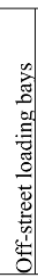 & 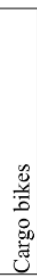 & 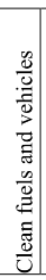 & 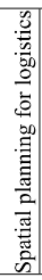 & 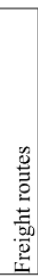 & 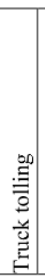 & 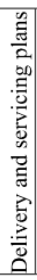 & $\begin{array}{l}\frac{n}{0} \\
\frac{0}{0} \\
\frac{0}{3} \\
0 \\
\frac{0}{2}\end{array}$ & 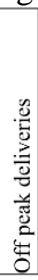 & 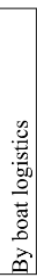 & 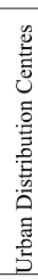 & 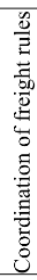 \\
\hline \multicolumn{13}{|l|}{ Category } \\
\hline Regulation & $\bullet$ & $\bullet$ & $\bullet$ & & $\bullet$ & $\bullet$ & & & & & • & $\bullet$ \\
\hline Technology & & & & & $\bullet$ & $\bullet$ & & & & & & \\
\hline Infrastructures & $\bullet$ & & $\bullet$ & $\bullet$ & & & & & & & $\bullet$ & \\
\hline Services & & $\bullet$ & & & & & $\bullet$ & - & $\bullet$ & $\bullet$ & $\bullet$ & \\
\hline Industrial/econ & & & $\bullet$ & & & & $\bullet$ & & & & & \\
\hline Urban planning & $\bullet$ & & & $\bullet$ & & & & & & & & \\
\hline Energy & & & $\bullet$ & & & & & & & & & \\
\hline \multicolumn{13}{|l|}{ Scale of application } \\
\hline Specific area & - & $\bullet$ & & & & & $\bullet$ & - & - & $\bullet$ & $\bullet$ & \\
\hline City centre & $\bullet$ & $\bullet$ & $\bullet$ & & & & $\bullet$ & $\bullet$ & $\bullet$ & $\bullet$ & $\bullet$ & \\
\hline City/FUA & $\bullet$ & & $\bullet$ & $\bullet$ & $\bullet$ & $\bullet$ & $\bullet$ & & & & & $\bullet$ \\
\hline
\end{tabular}

As evident from the Table 2, measures were benchmarked in terms of the category of measures type and the territorial level of applicability.

With reference to the category of the measure types, it is to be mentioned that only the Clean fuels and vehicles mobility schemes are included in the category concerning energy measures. 
$140 \quad 10^{\mathrm{TH}}$ INTERNATIONAL CONFERENCE ON SUSTAINABLE ENERGY AND ENVIRONMENTAL Protection (June $27^{\mathrm{TH}}-30^{\mathrm{TH}}, 2017$, Bled, Slovenia), ENERgy Management AND POLICIES

T. Letnik, G. Luppino, A. Bardi \& S. Bozicnik: Policies and Measures for Sustainable and Energy Efficient Urban Freight Transport

This fact, several measures have indirect energy benefits due to the optimisation of transport flows (e.g. fuel savings), the introduction of clean vehicles for logistics operations (e.g. electric mobility) or modal shift (e.g. use of transport means with lower energy impact). We have included in the energy category only the measure type that can directly focus on energy issues (in particular the development of electric mobility schemes which can be part of energy policies at urban level).

\section{$5 \quad$ Conclusions}

The analysis has shown that there is a vast variety of logistic and mobility measures and planning approaches in different European cities.

Standardisation of approaches on the cities as well as on the functional urban areas level is needed. Experiences of several cities have shown so far that selection of appropriate measures and planning mechanisms is a very promising solution.

Several studies have shown so far that a focused and appropriate measures in the field of city and functional urban area logistics and mobility measures and plans can on average decrease the energy consumption and $\mathrm{CO} 2$ footprint for about $15-30 \%$. On this way, we can contribute to the realisation of the EU Commission aim of $\mathrm{CO} 2$ free city.

\section{Acknowledgements}

The research leading to these results has received funding from the Interreg CENTRAL EUROPE project CE222 - SULPiTER - Sustainable Urban Logistics PlannIng To Enhance Regional freight transport. It reflects only the author's view and the Union is not liable for any use that may be made of the information contained therein.

\section{References}

[1] "Final energy consumption, EU-28, 2014 (\% of total, based on tonnes of oil equivalent)," EUROSTAT. [Online]. Available: http://ec.europa.eu/eurostat/statisticsexplained/index.php/Consumption_of_energy.

[2] EC, "White Paper - Roadmap to a Single European Transport Area - Towards a competitive and resource efficient transport system," 2011.

[3] P. D. United Nations, Department of Economic and Social Affairs, "World Urbanization Prospects," 2014.

[4] "Guidelines - Developing and implementing a Sustainable Urban Mobility Plan," 2014.

[5] “A Concept for Sustainable Urban Mobility Plans,” 2013.

[6] F. Wefering, S. Rupprecht, S. Bührmann, and S. Böhler-Baedeker, "Guidelines. Developing and Implementing a Sustainable Urban Logistics Plan," 2014.

[7] OECD, "Redefining 'Urban': A New Way to Measure Metropolitan Areas," 2012.

[8] "Eltis - The urban mobility observatory.".

[9] "2MOVE2 - CIVITAS Initiative." [Online]. Available: http://www.civitas.eu/content/2move2.

[10] “ADVANCE - Audit To Impeove Sustainable Urban Mobility.” [Online]. Available: 
T. Letnik, G. Luppino, A. Bardi \& S. Bozicnik: Policies and Measures for Sustainable and Energy Efficient Urban Freight Transport

[11] "BUMP - Boosting Urban Mobility Plans." [Online]. Available: http://www.bumpmobility.eu/en/home.aspx.

[12] "CH4LLENGE - Addressing the four key challenges of sustainable urban mobility planning." [Online]. Available: http://www.sump-challenges.eu/.

[13] “CIVINET - CIVITAS National Networks." [Online]. Available: http://civitas.eu/civinet.

[14] "Do The Right Mix - Sustainable Urban Mobility." [Online]. Available: http://dotherightmix.eu/.

[15] “DYN@MO - Civitas Initiative.”[Online]. Available: http://civitas.eu/content/dynmo.

[16] "EcoMobility SHIFT - assessing urban transport performance." [Online]. Available: https://ecomobility.org/ecomobility-shift/.

[17] "ENDURANCE - European SUMP Network." [Online]. Available: http://www.epomm.eu/endurance/index.php.

[18] "PUMAS - Planning sustainable regional Urban Mobility in the Alpine Space Programme Alpine Space.” [Online]. Available: http:/www.pumasproject.eu.

[19] "SOLUTIONS - Sharing Opportunities for Low carbon Urban transporTatION." [Online]. Available: http://www.urban-mobility-solutions.eu/.

[20] “TIDE - Transport Innovation Deployment for Europe." [Online]. Available: http://www.tide-innovation.eu/en/.

[21] A. Stathopoulos, E. Valeri, and E. Marcucci, "Stakeholder reactions to urban freight policy innovation," J. Transp. Geogr., vol. 22, pp. 34-45, 2012.

[22] M. Browne, M. Piotrowska, A. Woodburn, and J. Allen, "Literature Review WM9: Part I Urban Freight Transport," no. January 2007, p. 49, 2007.

[23] G. Giuliano, "Introduction to the special issue "Managing freight in urban areas," Res. Transp. Bus. Manag., vol. 11, pp. 2-4, 2014.

[24] "Bestfact - Best Practice Factory for Freight Transport." [Online]. Available: http:/www.bestfact.net.

[25] "CITYLOG - Sustainability and Efficiency of City Logistics." [Online]. Available: http://www.transport-research.info/project/sustainability-and-efficiency-city-logistics. 


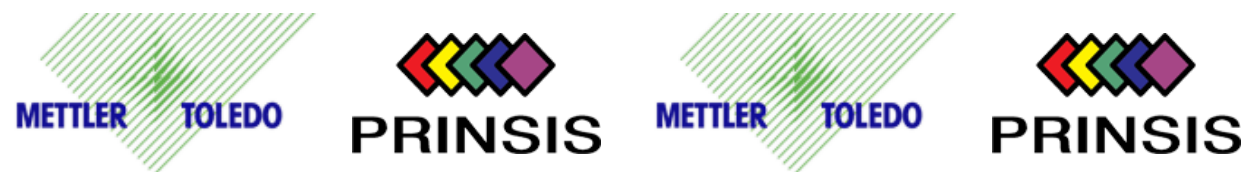

$€$ energetika ljubljana $€$ energetika ljubljana

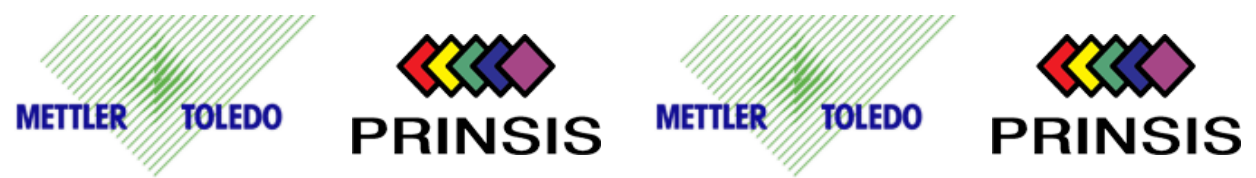

$€$ energetika ljubljana $€$ energetika ljubljana

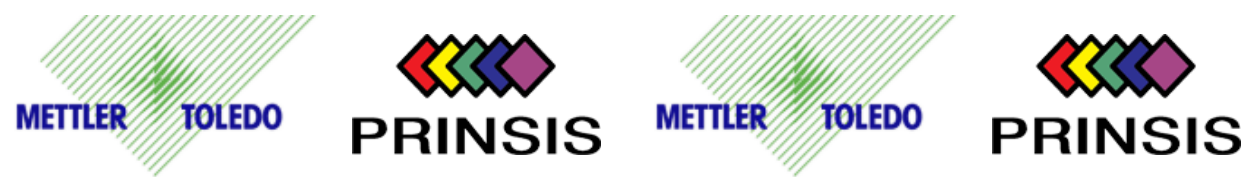

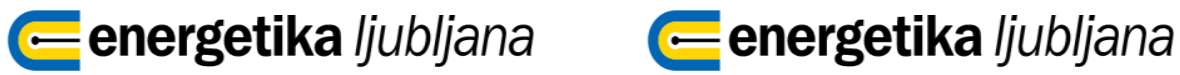

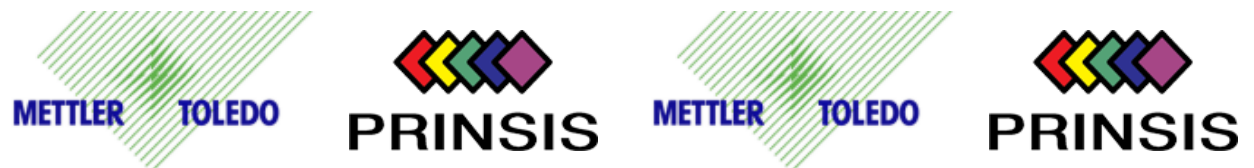

$€$ energetika ljubljana $€$ energetika ljubljana

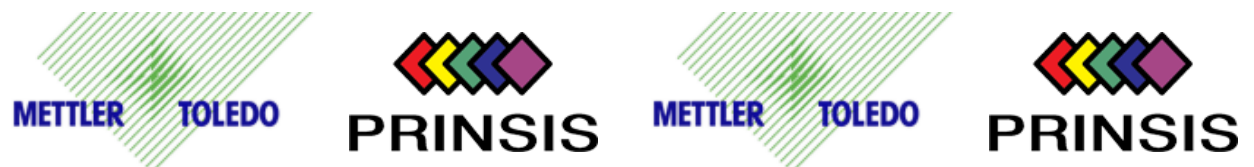

$€$ energetika ljubljana $€$ energetika ljubljana 